Portland State University

PDXScholar

7-2-1996

\title{
Correlation of the Upper Ellensburg Formation with the Old Scab Mountain Eruptive Center, East-Central Cascade Range, Washington
}

Christopher Charles Humphrey

Portland State University

Follow this and additional works at: https://pdxscholar.library.pdx.edu/open_access_etds

Part of the Geology Commons

Let us know how access to this document benefits you.

\section{Recommended Citation}

Humphrey, Christopher Charles, "Correlation of the Upper Ellensburg Formation with the Old Scab Mountain Eruptive Center, East-Central Cascade Range, Washington" (1996). Dissertations and Theses. Paper 5287.

https://doi.org/10.15760/etd.7160

This Thesis is brought to you for free and open access. It has been accepted for inclusion in Dissertations and Theses by an authorized administrator of PDXScholar. Please contact us if we can make this document more accessible: pdxscholar@pdx.edu. 


\section{THESIS APPROVAL}

The abstract and thesis of Christopher Charles Humphrey for

the Master of Science degree in Geology were presented July 2, 1996 and accepted by the thesis committee and the department.

COMMITTEE APPROVALS:

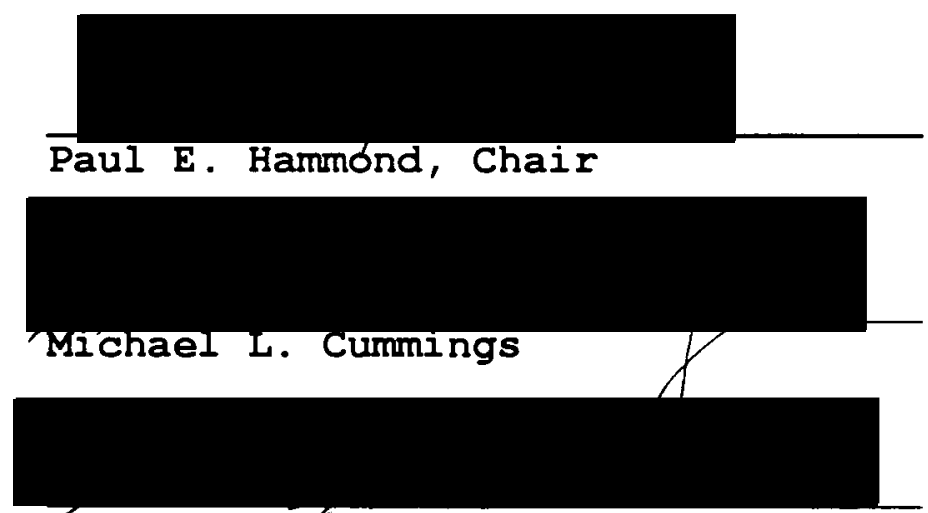

Marvin H. Beeson

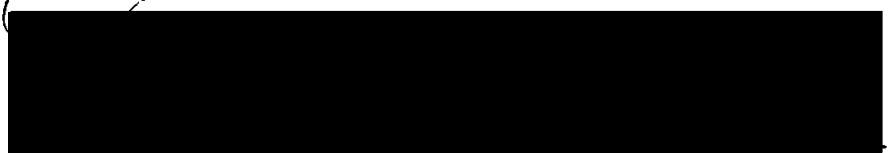

Deborah A. Duffield

Representative of the office of Graduate Studies

DEPARTMENT APPROVAL:

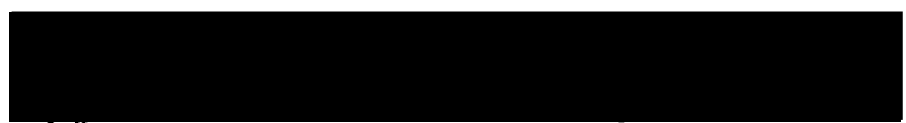

Jarvin H. Beeson, Chair Department of Geology

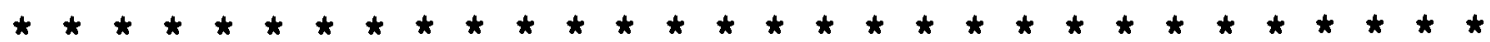

ACCEPTED FOR PORTLAND STATE UNIVERSITY BY THE LIBRARY by on 23 lecquest 1986 


\section{ABSTRACT}

An abstract of the thesis of Christopher Charles Humphrey for the Master of Science in Geology: presented July 2, 1996.

Title: Correlation of the upper Ellensburg Formation with the Old Scab Mountain eruptive center, east-central Cascade Range, Washington.

The Ellensburg Formation, preserved in the Nile basin 50 $\mathrm{km}$ northwest of Yakima, Washington, consists of a series of middle to late Miocene epiclastic and pyroclastic rock assemblages rich in porphyritic hornblende-biotite dacite. Geochemical, petrographic, and stratigraphic correlations indicate that old Scab Mountain, a dacite porphyry intrusion, located at the western margin of the basin (lat. 46 $53^{\prime} 30^{\prime \prime}$, long. $\left.121^{\circ} 13^{\prime} 00^{\prime \prime}\right)$, is the probable source for much of the upper Ellensburg volcaniclastic material in the basin. The dacite intrusion exposed at Old Scab Mountain was emplaced at depths of 1 to $3 \mathrm{~km}$ and underlaid a now eroded volcanic edifice. This volcanic center is interpreted to have been active during the time of deposition of the upper Ellensburg Formation. A K-Ar age of $8.75 \pm 0.20 \mathrm{Ma}$ for an adjacent sill of similar dacite suggests an age for Old Scab Mountain between 9 to $7 \mathrm{Ma}$ (Smith, 1988a). This age corresponds with 
the upper Ellensburg Formation which stratigraphically overlies Grande Ronde Basalt lava flows of the Columbia River Basalt Group, within the basin.

Stratigraphic reconstruction of the Nile basin deposits indicates a dome collapse eruptive style. Progressive dome growth was punctuated by short-lived eruptions resulting in dome collapse and deposition of debris-avalanche and lahar deposits. These deposits were remobilized by fluvial processes which generated thick conglomerates and interstratified volcanic sandstones.

Upper Ellensburg deposits and dacite of old Scab Mountain are calc-alkaline and medium-K in composition. Silica content ranges from 53 to 67 weight percent $\mathrm{SiO}_{2}$ for upper Ellensburg deposits and 66 to 67 weight percent $\mathrm{SiO}_{2}$ for dacite of old scab Mountain.

Older deposits composing the lower Ellensburg Formation are interbedded with and underlie the Grande Ronde Basalt. The lower Ellensburg deposits are typically more tholeitic, range from 56 to 74 weight percent $\mathrm{SiO}_{2}$, and show slightly higher trace element concentrations than the upper Ellensburg deposits. These deposits were possibly derived from other dacite centers located near the headwaters of the adjacent Naches basin. 
CORRELATION OF THE UPPER ELIENSBURG FORMATION

WITH THE OLD SCAB MOUNTAIN ERUPTIVE CENTER,

EAST-CENTRAL CASCADE RANGE, WASHINGTON

\author{
by \\ CHRISTOPHER CHARLES HUMPHREY
}

a thesis submitted in partial fulfillment of the requirements of the degree of

MASTER OF SCIENCE

in

GEOLOGY

Portland State University

1996 


\section{ACKNOWLEDGMENTS}

I would like to thank the Mazamas and the Geological Society of America for their funding of this thesis. Without their support much of this research would not have been possible. I would also like to thank Beverly Vogt of the Department of Oregon Geology and Mineral Industries (DOGAMI), who acted as the Mazamas' representative, for her encouragement and support throughout my research.

Thesis advisor and committee member Dr. Paul Hammond of Portland State University is acknowledged for his guidance and insight in my thesis research. Thesis committee members Dr. Marvin Beeson and Dr. Michael Cummings of Portland state University are thanked for their guidance and their help in carrying out instrumental neutron activation analysis (INAA) for trace element geochemistry.

Dr. Steven Frantz of Reed College is acknowledged for conducting the irradiation of rock samples in preparation of INAA. Michael Pollock of Reed College is thanked for his heroic efforts in salvaging the first counts of INAA from mechanical breakdown.

Dr. Peter Hooper of Washington State University in Pullman is thanked for the use of the washington state GeoAnalytical Laboratory and his supervision in performing $\mathrm{X}-$ ray fluorescence (XRE) geochemical analysis. Special thanks 
goes to Diane Johnson of Washington State University in Pullman for her help in preparing rock samples and XRF analysis.

Dr. Kenneth Cruikshank of Portland state University is thanked for his help in navigating the Internet and converting digital elevation model (DEM) data into more workable formats. I would like to thank John Wyatt of Portland State University for his volunteered help in preparing rock samples for XRF analysis at Washington State University. His efforts allowed the preparation of rock samples to be conducted in a much faster and organized manner.

I would also like to thank steve and Mary Mitchell (and family) of Yakima, Washington for their friendly company around a blazing camp fire, and for some of the tallest glasses of coke and bourbon I've ever seen (and drank). 


\section{TABLE OF CONTENTS}

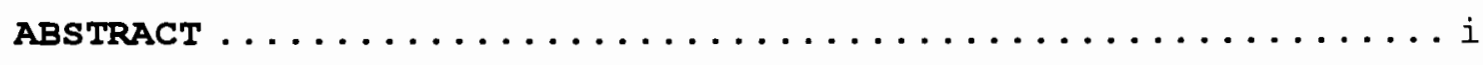
ACKNOWLEDGMENTS ....................... . . . . . TABLE OF CONTENTS $\ldots \ldots \ldots \ldots \ldots \ldots \ldots \ldots \ldots \ldots \ldots \ldots$

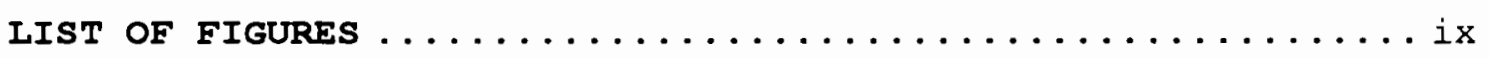

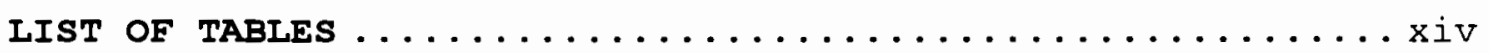

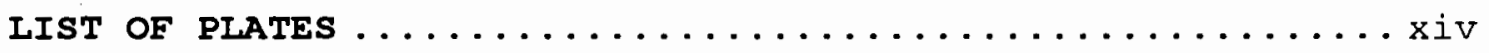

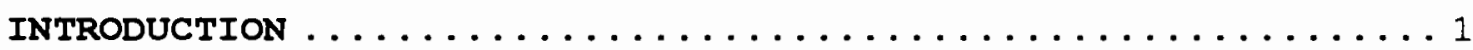

PURPOSE AND SCOPE $\ldots \ldots \ldots \ldots \ldots \ldots \ldots \ldots \ldots \ldots \ldots$

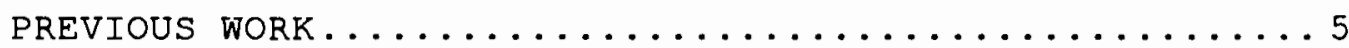
GEOLOGIC SETTING ..................... 8

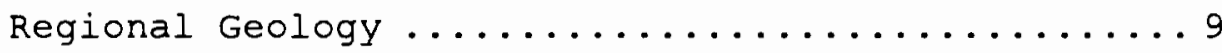

Regional structures .................... 10

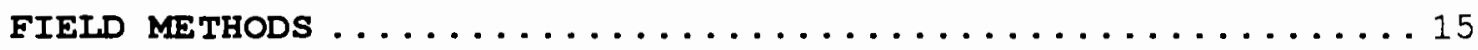

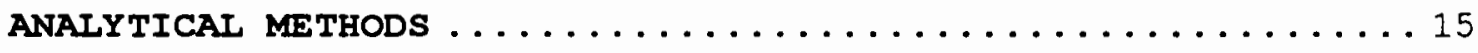

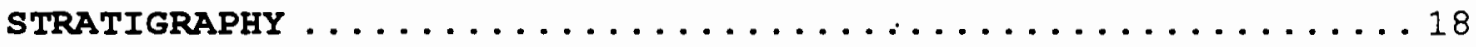

UNDIFFERENTIATED TERTIARY vOLCANICS ............ 19

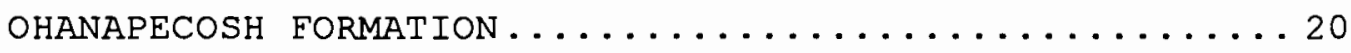
BUMPING RIVER TUFE..................... 20

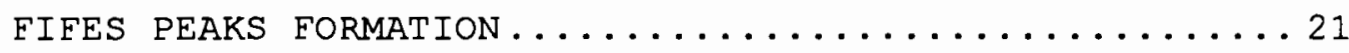
COLUMBIA RIVER BASALT GROUP................ 22

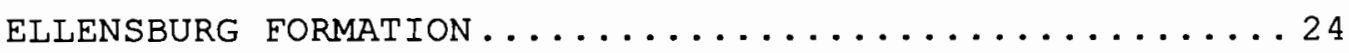

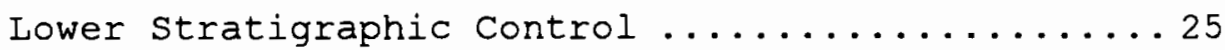

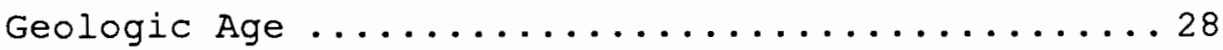
stratigraphy ....................... 29 
Facies Characteristics ................49

VOLCANIC FACIES ................ 49

Pyroclastic Flow Deposits..........49

Pyroclastic Fall Deposits......... 52

Laharic Deposits.............. 54

Lava Flows................... 58

ELUVIAL FACIES ................60

Conglomerates...............6 60

sandstones....................62

Mudstones..................6 63

DACITIC INTRUSIONS .................... 64

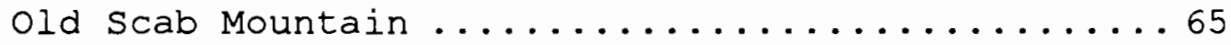

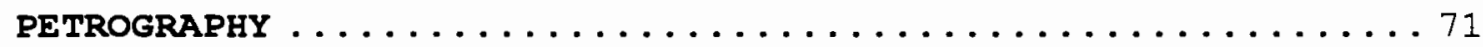

OLD SCAB MOUNTAIN ....................... 71

Plagioclase ........................ 75

Quartz ........................... 78

Magnetite ......................... 79

Ferromagnesium silicates ............. 80

HORNBLENDE ................... 84

BIOTITE ....................... 85

ORTHOPYROXENE .................. 85

CLINOPYROXENE ................. 87

ELLENSBURG FORMATION .................. 87

Plagioclase ......................... 89

Quartz ............................. 


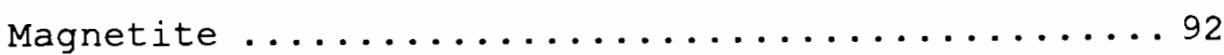

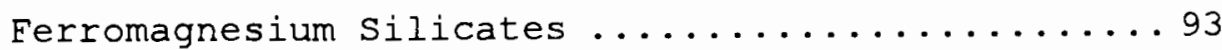

Hornblende ........................ 93

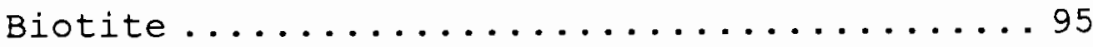

Orthopyroxene .................. 97

Clinopyroxene .................. 98

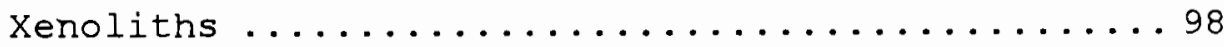

PETROGRAPHIC COMPARISION .................. 99

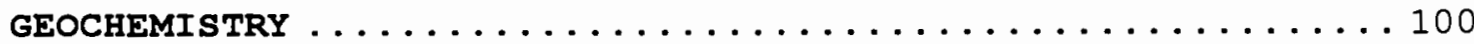

MAJOR ELEMENTS ....................... 100

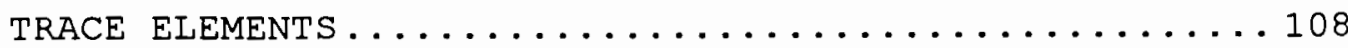

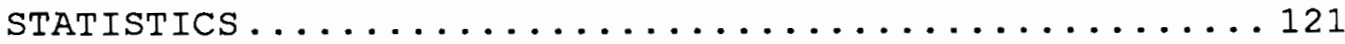

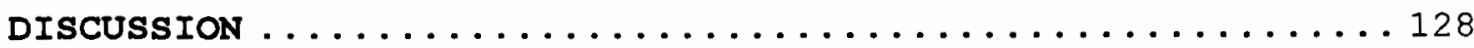

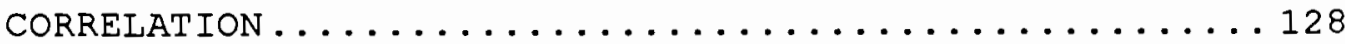

Stratigraphic Correlation .............. 128

Age Correlation ....................... 131

Chemical Correlation ................... 133

EERROMAGNESIUM SILICATE QUANTITATIVE ANALYSIS....... 136 INPLACEMENT DEPTH OF THE DACITE OF OLD SCAB MOUNTAIN.. 139 ERUPTIVE AND DEPOSITIONAL HISTORY ............. 142

Magmatic Reservoir ................... 144

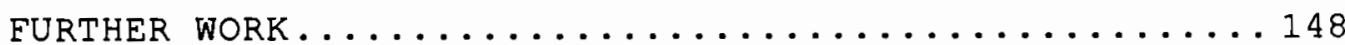

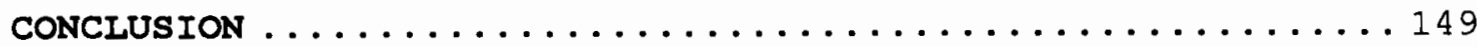

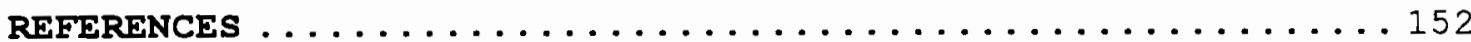

APPENDIX

A. XRF RESULTS 
B. INAA RESULTS

C. SAMPLE LOCATIONS AND GENERALIZED DESCRIPTIONS

D. EIGENVALUES, EIGENVECTORS, AND CALCULATED FACTORS 


\section{LIST OF FIGURES}

Figure 1 - Location map of the study area in washington ......

Figure 2 - Topographic map of the study area in

Washington (from U.S. Geologic Survey Yakima

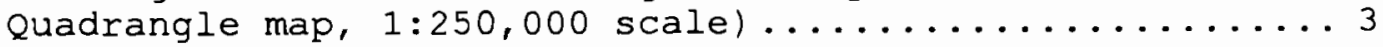

Figure 3 - Stratigraphic relationship between the

Ellensburg Formation and the Columbia River Basalt

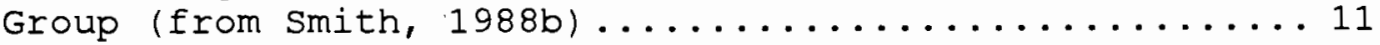

Figure 4 - Structural map of the study area in

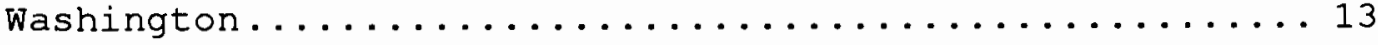

Figure 5 - Fault brecciated basalt of the Columbia River Basalt Group (CRBG) exposed along NF trail \#975,

southeast of old scab Mountain................ 27

Figure 6 - Pyroclastic flow deposits within the lower

Ellensburg Formation exposed along NF local road

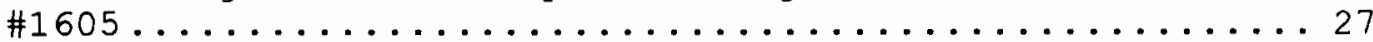

Figure 7 - Location map of the stratigraphic sections

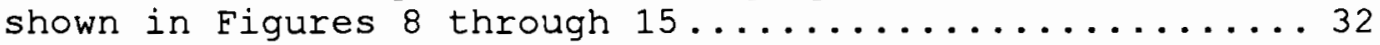

Figure 8 - Stratigraphic section " $A$ " of the upper

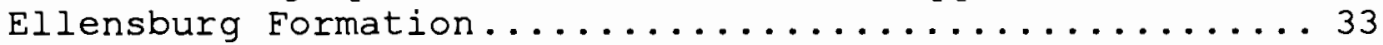

Figure 9 - Stratigraphic section " $B$ " which includes the upper Ellensburg Formation, Grande Ronde Basalt and

the lower Ellensburg Formation................ 34

Figure 10 - Stratigraphic section "C" of the upper

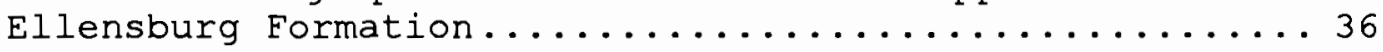

Figure 11 - Stratigraphic section " $D$ " which includes the upper and lower Ellensburg Formation............ 37

Figure 12 - Stratigraphic section " $E$ " of the upper

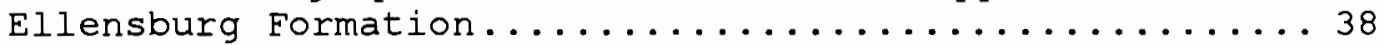

Figure 13 - Stratigraphic section " $F$ " which includes the upper Ellensburg Formation and Grande Ronde Basalt..... 39

Figure 14 - Stratigraphic section " $G$ " of the Fifes Peak Formation............................ 43 
Figure 15 - Stratigraphic section "H" of the upper

Ellensburg Formation.................... 45

Figure 16 - Generalized stratigraphic positions of sections A through $H$ (Figs. 8 through 15) in the Nile basin. Unit thickness and section lateral positions are generalized.................. 47

Figure 17 - Interbedded pumiceous sedimentary and volcanic air-fall deposits. Dark colored backpack is on air-fall ash deposits. Above backpack is a trough-bedded pumiceous volcanic sandstone. Exposure along $\mathrm{NF}$ collector road \#1600........... 56

Figure 18 - Basaltic laharic deposit of the lower Ellensburg Formation. Contains dark-colored lithic clasts, white and gray pumice in a tan lapilli tuff matrix. Exposure along NF road 1920 road along Fifes Ridge, north of American River............. 56

Figure 19 - Large dacitic boulder in debris avalanche deposit exposed along $\mathrm{NF}$ local road \#233...........59

Figure 20 - Debris avalanche deposits exposed along $\mathrm{NF}$

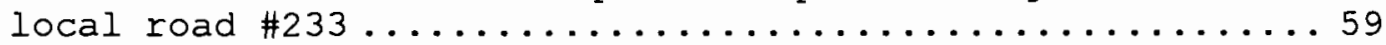

Figure 21 - Dacitic lava flow approximately $14 \mathrm{~km}$ east of Old Scab Mountain exposed along $\mathrm{NF}$ local road

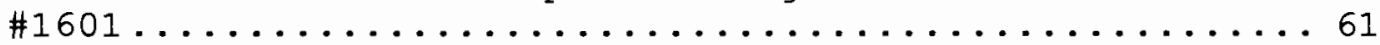

Figure 22 - Clast supported dacitic conglomerate exposed along $\mathrm{NF}$ local road \#236, immediately north of orr

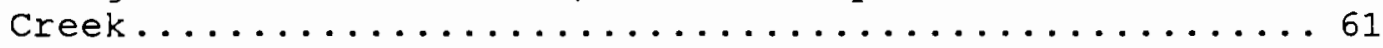

Figure 23 - Looking south towards old Scab Mountain from

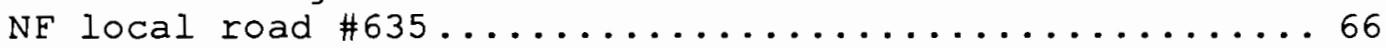

Figure 24 - Looking west towards Old Scab Mountain from Little Bald Mountain.....................66

Figure 25 - Cliff slope exposure on north side of old Scab Mountain. Upper slope exposing conchoidal jointing patterns...................... 68

Figure 26 - Panorama of west cirque wall of Old Scab Mountain. Photograph showing conchoidal and columnar jointing patterns...................69 
Eigure 27 - Photomicrograph of dacite of old Scab Mountain (50X, cross-polarized, Sample \#94080) .......777

Figure 28 - Photomicrograph of zoned plagioclase crystal in dacite of old Scab Mountain (50X, crosspolarized, sample \#94079) .................. 77

Figure 29 - Photomicrograph of quartz grains with overgrowths of plagioclase surrounded by an additional layer or "shell" of quartz in dacite of old Scab Mountain (50x, cross-polarized, sample \#94019) ................................. 8

Eigure 30 - Photomicrograph of hornblende with reaction rim of orthopyroxene, magnetite and plagioclase in dacite of old Scab Mountain (50X, plain-polarized, sample \#94079) .......................... 8

Figure 31 - Photomicrograph of biotite with reaction rim of orthopyroxene, magnetite and plagioclase in dacite of old Scab Mountain (50X, plain-polarized,

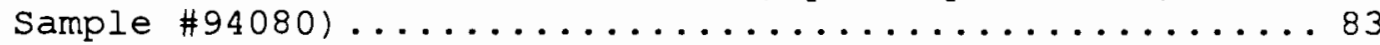

Figure 32 - Photomicrograph of aggregation of breakdown minerals (orthopyroxene, magnetite and plagioclase) in dacite of Old Scab Mountain. The original parent mineral has been completely replaced (50X, plain-polarized, Sample \#94080) ................ 83

Figure 33 - Photomicrograph of pseudohexagonal hornblende phenocryst with reaction rim of orthopyroxene, magnetite and plagioclase in dacite of old Scab Mountain (200x, cross-polarized, Sample

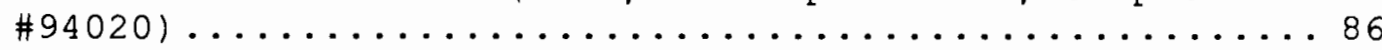

Figure 34 - Photomicrograph of orthopyroxene phenocryst crowded with magnetite with orthopyroxene microlites in matrix in dacite of old scab Mountain (50X, plain-polarized, Sample \#94079) .............86

Eigure 35 - Photomicrograph of dacite clasts in upper Ellensburg Formation (50X, cross-polarized, Samples

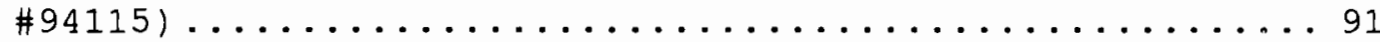


Figure 36 - Photomicrograph of "pitted" plagioclase phenocryst in dacite clast found in a pyroclastic flow in the upper Ellensburg Formation (50x, plain-

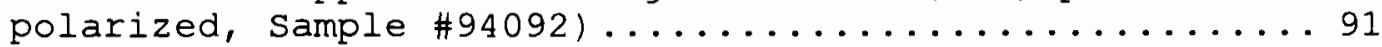

Figure 37 - Photomicrograph of 'black' type reaction of hornblende phenocryst in dacite clasts found in a lahar flow in the upper Ellensburg Formation (50X,

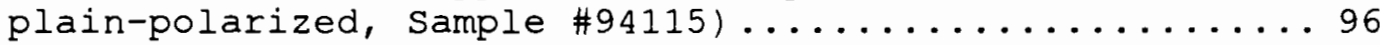

Figure 38 - Photomicrograph of biotite phenocryst with orthopyroxene, magnetite and plagioclase reaction rim in dacite clast found in a pyroclastic flow in the upper Ellensburg Formation (50X, crosspolarized, Sample \#94010) .................... 96

Figure 39 - Total alkali-silica (TAS) diagram of lower Ellensburg rocks (open circles), upper Ellensburg rocks (open diamonds) and dacites from old Scab

Mountain (closed squares) ......................... 101

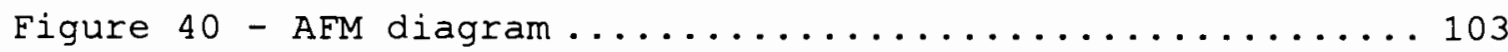

Figure 41 - Major-element Harker variation diagrams....... 104

Figure 42 - $\mathrm{SiO}_{2}$ wto (a), $\mathrm{Na}_{2} \mathrm{O}$ wto (b), $\mathrm{P}_{2} \mathrm{O}_{5}$ wto (c) and $\mathrm{TiO}_{2}$ wto (d) of Ellensburg samples of stratigraphic section " $F$ " arranged progressively up section........ 109

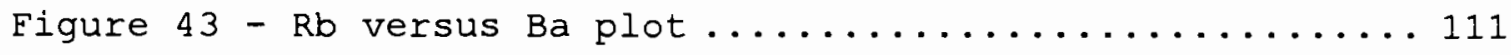

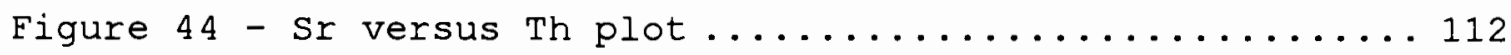

Figure $45-\mathrm{Sr}$ versus $\mathrm{Ca} / \mathrm{Sr}$ plot ................... 114

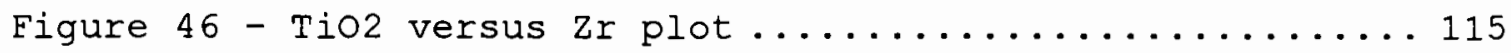

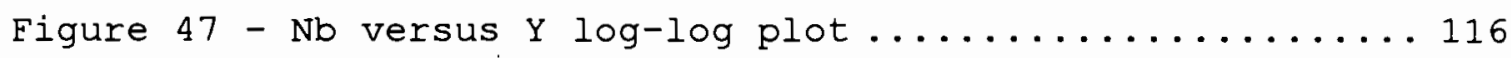

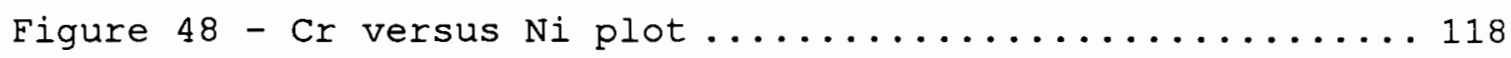

Figure 49 - Spider diagram plot showing the compositional range of lower Ellensburg rocks, upper Ellensburg rocks, and two dacite samples from old Scab Mountain (after Thompson and others, 1982)... 119 
Figure 50 - spider diagram plot of dacitic lava flow and two dacite samples from old Scab Mountain (after

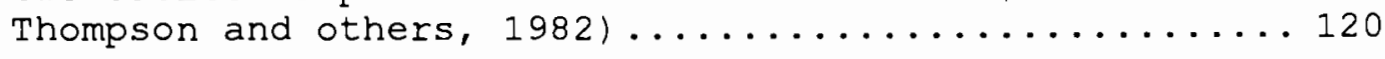

Figure 51 - Spider diagram plot showing chondritenormalized rare earth element composition of lower Ellensburg rocks, upper Ellensburg rocks, and dacite samples from old scab Mountain (after sun

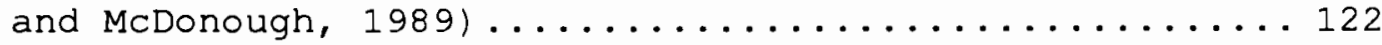

Figure 52 - Correlation coefficient of XRF major oxide elements (a), and XRF trace elements (b), of all Ellensburg and Old Scab Mountain samples compared

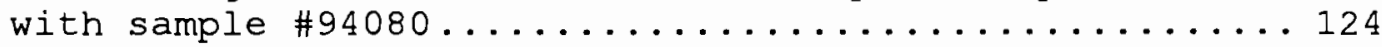

Figure 53 - Factor II versus Factor III of lower Ellensburg rocks, upper Ellensburg rocks, and dacite samples from old Scab Mountain. Factors derived from $Q$-mode factor analysis............. 127

Figure 54 - Cross section extending from old Scab Mountain east-southeast into the Nile basin........ 132

Figure 55 - Hydrous phase mineral percentage plotted against orthopyroxene microlites of upper Ellensburg rocks and dacites from old Scab Mountain. (a) Biotite versus orthopyroxene, (b) hornblende versus orthopyroxene, (c) hornblende + biotite versus orthopyroxene. Symbols are shown in

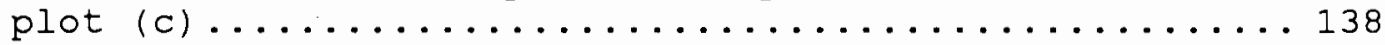

Figure 56 - General diagram illustrating proposed Nile basin volcano (a) prior to the emplacement of the old scab Mountain intrusion, and (b) after the emplacement of the old Scab Mountain intrusion. Dashed line defines generalized hornblende ( $\mathrm{Hb}$ ) stability field........................ 147 


\section{Iist of Tables}

Table 1 - Thickness ( 8 ) of major facies types in the

$\underline{\text { Page }}$

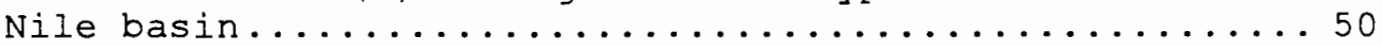

Table 2 - Modal Analyses of thin sections ............. 72

\section{List of Plates}

Plate 1 - Geologic map of the Nile basin........... (insert) 


\section{INTRODUCTION}

The Ellensburg Formation consists of a sequence of dacitic epiclastic and pyroclastic rock assemblages of middle to late Miocene age exposed along the eastern slopes of the central Washington Cascade Range near Yakima, Washington. These deposits form a volcaniclastic apron over older, more mafic deposits of the Fifes Peaks and Ohanapecosh Formations which make up much of the central Washington Cascade arc. The Ellensburg Formation is the major volcaniclastic sedimentary unit deposited in the east-central Cascade Range during middle to late Miocene time. Volcaniclastic and sedimentary deposits of the Ellensburg Formation are concentrated in seven main depositional basins; Nile, Selah, Yakima, Moxee, Kittitas, Toppenish and Ellensburg (Smith, 1988a). This thesis deals with the Nile basin which represents the most proximal of the six basins in relation to its volcanic source area.

The Nile basin is located approximately $45 \mathrm{~km}$ east of Mount Rainier and is bounded by Rattlesnake Creek to the south, the Naches River to the north, and the Bumping River to the west (Figs. 1 and 2). The study area lies in the Naches Ranger District of the Wenatchee National Forest. It is within the transitional zone of the mountainous cascades Range to the west and the Columbia Plateau to the east. Elevation ranges from $695 \mathrm{~m}$ in the Naches River valley to $2015 \mathrm{~m}$ at the 


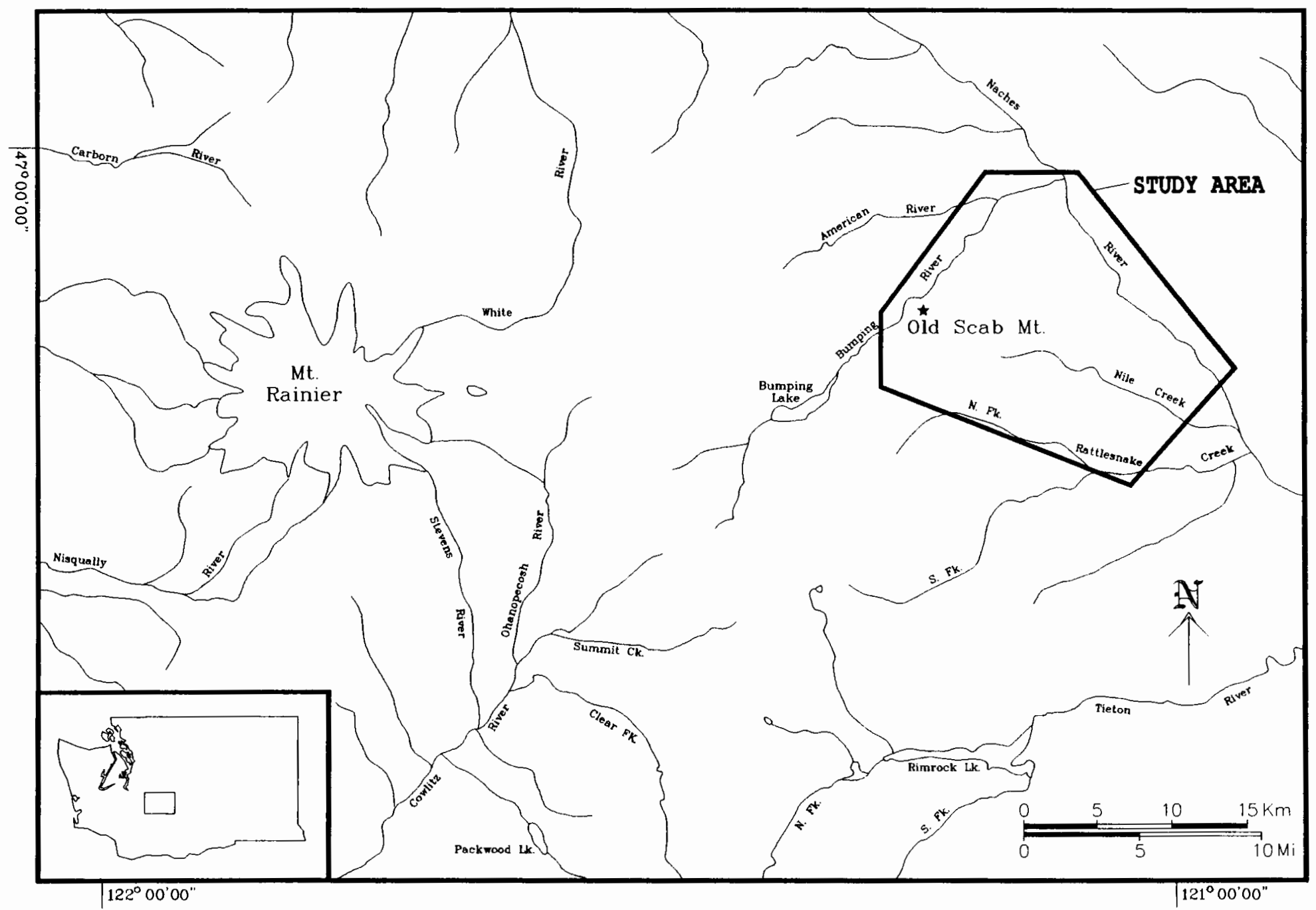

Figure 1 - Location map of the study area in washington. 
$121^{\circ} 15^{\prime}$

$121^{\circ} 00^{\prime}$
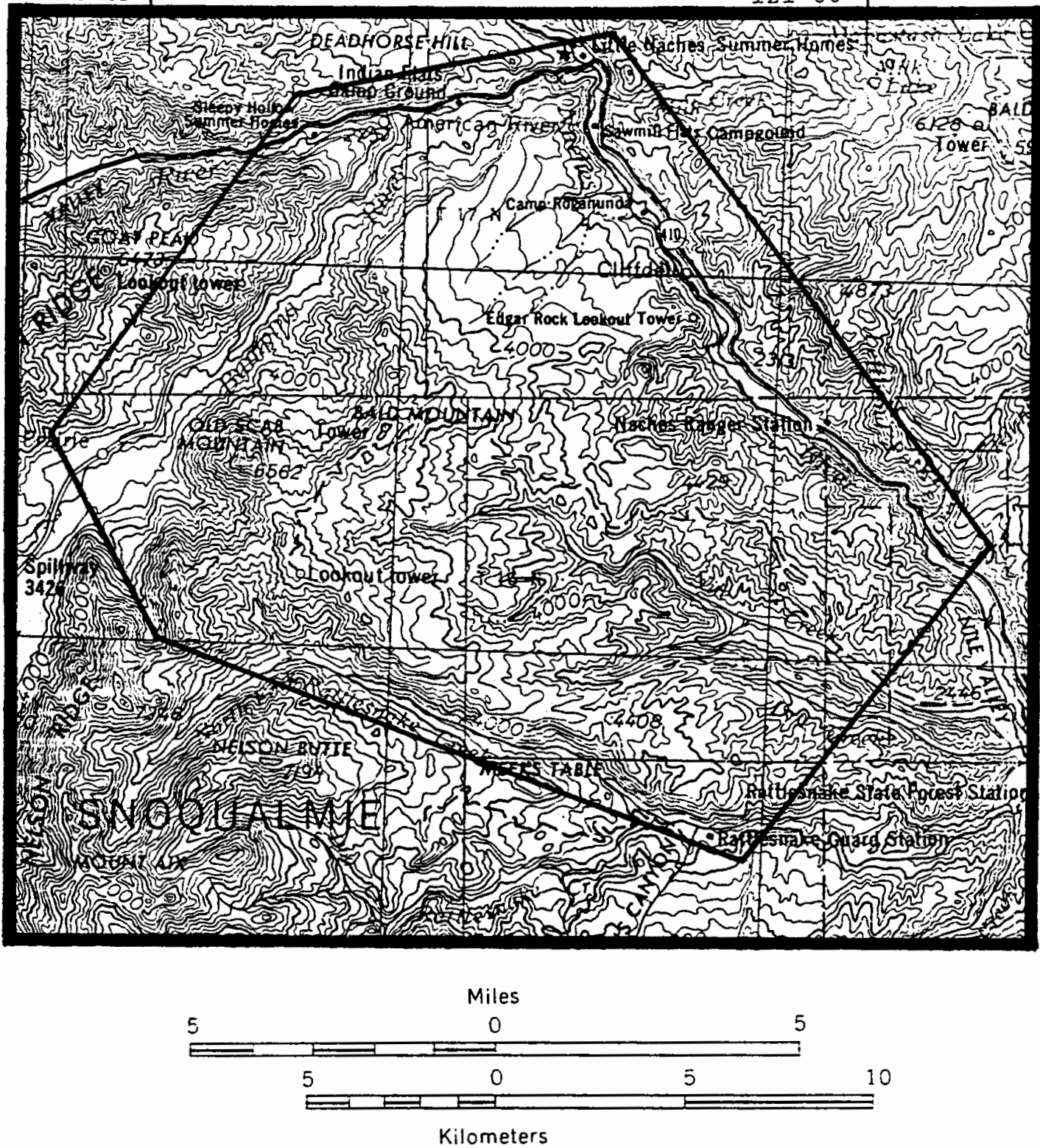

Scale $1: 250,000$

CONTOUR INTERVAL 200 FEET

Figure 2 - Topographic map of the study area in Washington (from U.S. Geologic Survey Yakima Quadrangle map, 1:250,000 scale). 
top of old Scab Mountain (Fig 2). Vegetation is transitional, from temperate Douglas fir and pine forests to the west to drier pine and sagebrush woodland to the east.

\section{PURPOSE AND SCOPE}

The purpose of this study is to determine the volcanic origin of the Ellensburg deposits within the Nile basin using stratigraphic, petrographic and geochemical techniques. Previous studies have primarily dealt with the sedimentary and depositional history of the Ellensburg Formation (Smith and others, 1988; Smith, 1988a). Little attention has been focused on understanding the volcanic origin of the material that makes up most of the Ellensburg deposits. Preliminary investigations suggest that much of the Ellensburg material in the Nile and Selah basins have a possible source within the region between Bumping Lake and the Naches River (Fig. 1). Several large porphyritic dacitic intrusions which are lithologically similar to the dacite clasts in the Ellensburg Formation occur within this region. One of the largest of these dacite-porphyry intrusions is old scab Mountain which is the nearest intrusion in the vicinity and has an age which corresponds with the Ellensburg Formation (Smith and others, 1988a; Smith and others, 1989b). 
The principal objectives of this study are to:

1) map and describe volcanic units and structural features ;

2) describe the stratigraphy of the Ellensburg deposits within the Nile basin;

3) describe and characterize the depositional style of volcanic deposits in the Ellensburg Formation;

4) petrographically and geochemically describe Ellensburg volcaniclastic deposits and dacite intrusions (primarily old Scab Mountain) and establish correlations.

This thesis describes and discusses the history of the Ellensburg Formation. It also attempts to correlate the Ellensburg Formation of the Nile basin to the dacite of old Scab Mountain. By understanding the volcanic origin of the Ellensburg materials it is hoped that a greater understanding of the depositional history of the Ellensburg Formation can be developed.

\section{PREVIOUS WORK}

The Ellensburg Formation was first described by Russell (1893) who initially classified it as a part of the John Day Formation; however, he later renamed it the Ellensburg 
Eormation for an outcrop of volcaniclastic sandstone and conglomerate found in the town of Ellensburg, Washington (Russell, 1900). Smith (1901) designated the first type sections and provided detailed descriptions. One type section was located near Normal School in the town of Ellensburg, and another more detailed section was located along the lower course of the Yakima River west of Yakima, Washington. Smith (1903) later constructed a detailed map and described the Ellensburg Eormation within the Ellensburg quadrangle. An updated geologic map of the Ellensburg quadrangle has been published by Bentley and Campbell (1983).

Coombs (1941) conducted heavy mineral analysis on eight samples of Ellensburg sandstone. These samples were located within the Nile, Selah, and Ellensburg basins. Laval (1948) performed a more detailed analysis on undifferentiated petrographic homogeneities within the Ellensburg.

Waters (1955) analyzed the Ellensburg Formation with respect to its geomorphic features. He described the structural features of the Yakima fold belt by looking at the geomorphic contact relationships of the Ellensburg Eormation and the Yakima Group of the Columbia River Basalts.

Mackin (1961) was one of the first to look at the depositional history of the Ellensburg by determining the changing rates of erosion and deposition within the stratigraphic record. 
Smiley (1963) studied fossilized flora to categorize the biologic and climatic changes during deposition of the Ellensburg Formation. He classified three main successions of Ellensburg forests, from an early swamp cypress forest to later semi-arid forests. He also demonstrated similarities between flora of the Ellensburg and the Dalles Formations. Schmincke (1964) carried out the most comprehensive study of the Ellensburg Formation to date. His Ph.D. dissertation examined the Ellensburg as a broad volcanic alluvial complex becoming more proximal to the west. Later work on graded lahar flows demonstrated an origin of the Ellensburg deposits coming from the volcanoes in an ancient Cascade chain to the west (Schmincke, 1967a). Schmincke (1967b) also examined the textures and minerals within welded ash flow tuffs of the Ellensburg Formation interbedded with Yakima Basalt flows.

Campbell (1975) wrote one of the few published field trip guides to cover the Ellensburg Formation in detail. This field guide begins in Yakima and introduces participants to the Ellensburg Formation in the Nile, Selah, and Ellensburg basins.

Luker (1985) studied the paleocurrents, facies distributions, depositional processes and petrology of the Ellensburg deposits in order to classify the distal and proximal nature of the sedimentary deposits. His work 
followed from Schmincke's (1967a) study on the deposition of lahar deposits. Luker was able to show that the Nile basin contains the most proximal lahar deposits becoming more distal to the east.

Smith (1988a; 1988b; 1991a; 1991b) and Smith and others (1988; 1989a; 1989b) have done extensive work describing the depositional style of the Ellensburg Formation. This work has primarily dealt with the inter-eruptive and syneruptive character of the volcaniclastic sedimentary deposits. They have also done extensive work in tracing the Ellensburg paleodrainage systems and measuring the influences of structural deformation on these drainages. Additionally, preliminary work was performed correlating laharic deposits of the Nile and Selah basins to a possible source area near Bumping Lake has set the foundation for this study.

\section{GEOLOGIC SETTING}

Late Cenozoic volcanism in the Cascade Range is attributed to subduction of the Juan de Fuca plate beneath the North American plate. The Juan de Fuca plate is the remnant of an older, now largely consumed Faralion plate. Presently, the Cascade Range forms a narrow, $1100 \mathrm{~km}$ north-south chain of composite and shield volcanoes extending from northern California north to southern British Columbia. Prior to 
uplift of the Cascade Range beginning at about 7 Ma (Hammond, 1989) the range formed a much broader zone of volcanic vents centered east of its present location (Guffanti and Weaver, 1988).

\section{Regional Geology}

According to Vance and others (1987), Cenozoic rocks of the east-central Washington Cascade Range can be assigned to four supracrustal sequences: (1) Eocene volcanic and sedimentary rocks, (2) Oligocene Ohanapecosh and OligoceneMiocene Fifes Peaks Formation, (3) middle Miocene Columbia River Basalt Group, and (4) Pliocene and Quaternary lavas and pyroclastic rocks. The Ohanapecosh and Fifes Peaks Formations were deposited during time of greatest accumulation of volcanic material within the Cascades arc. However, between 20 and $16 \mathrm{Ma}$, prior to the initiation of the volcanic eruptions which produced the Ellensburg Formation, there was a general decline in volcanic activity possibly resulting from a diminishing subduction rate (Riddihough, 1984; MCBirney and White, 1992). The onset of volcanic activity within the study area was accompanied by major rifting in southeastern Washington related to outpourings of the Columbia River basalts. The Ellensburg Formation within the Naches basin near Yakima, is separated into members on the basis of its stratigraphic relationships with flows of the Columbia River 
basalt (Smith, 1988b; Fig. 3). However, within the Nile basin only the Grande Ronde flows are present and underlie most of the Ellensburg Formation.

\section{Regional structures}

Two parallel, north-northwest striking structures dominate the region east of Mount Rainier: (1) the preTertiary Rimrock Lake inlier, and (2) the Olympic-Wallowa lineament (OWL) (Hammond and others, 1994). These structures have influenced the alignment of local volcanic centers and are locally defined by northwest-striking folds and faults within and near the study area.

The Rimrock Lake inlier is a structurally uplifted zone $25 \mathrm{~km}$ wide and $40 \mathrm{~km}$ long exposed southeast of Bumping Lake. It is represented by five pre-Tertiary units separated along north-northwest trending, vertical dipping tectonic contacts or shear faults (Schasse, 1987; Walsh and others, 1987; Miller, 1989; King, 1994; Hammond and others, 1994). Units include plutonic and metaplutonic crystalline rocks of the Indian Creek complex of Jurassic age, Jurassic-Cretaceous marine rocks of the Russell Ranch complex, and pre-Eocene silicic metavolcanic rocks of the Twin Sisters Lakes. Faults do not cut Tertiary strata; however, uplift of Tertiary strata has occurred and has caused a regional east-southeast dip of units. 


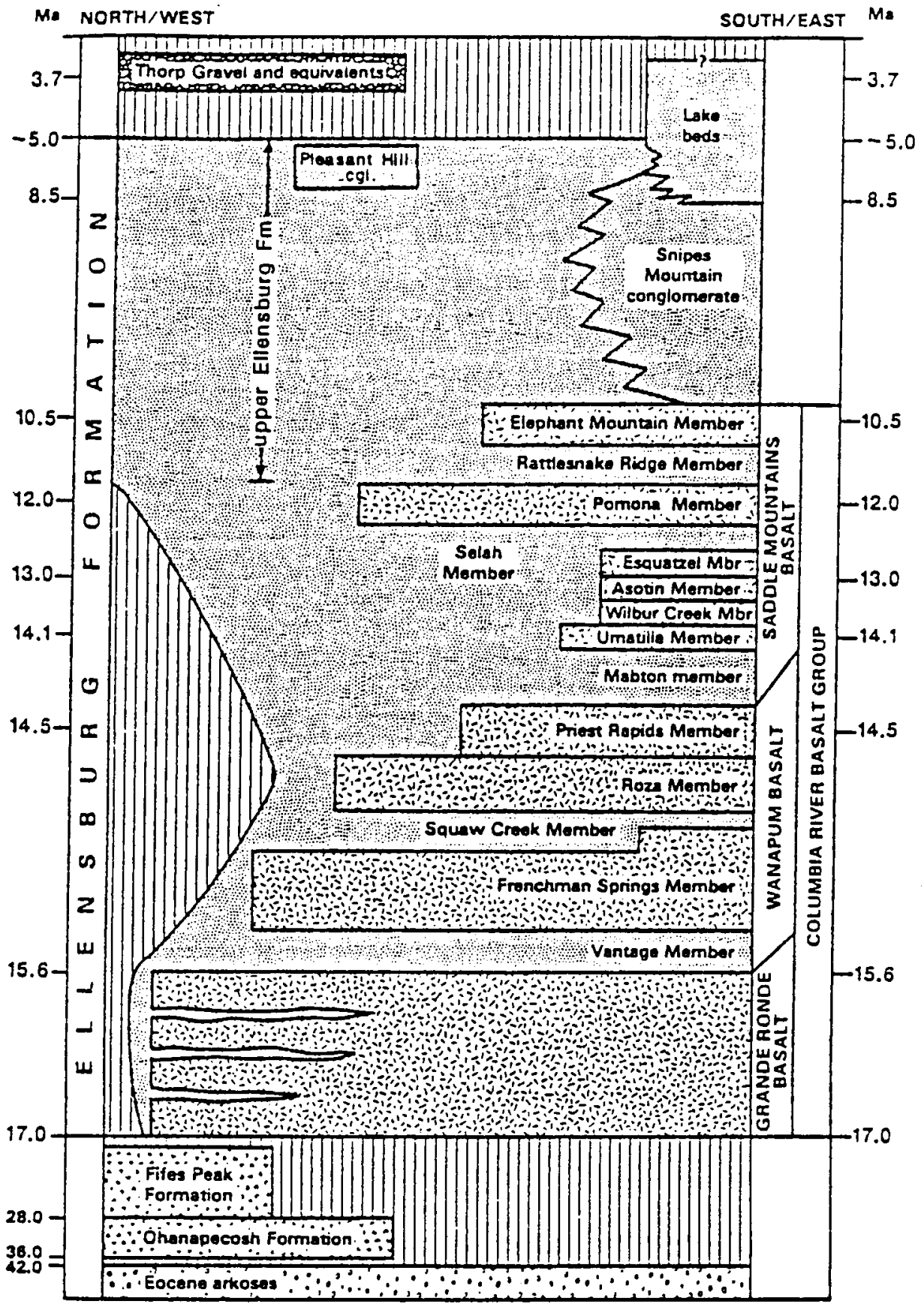

Figure 3 - Stratigraphic relationship between the Ellensburg Formation and the Columbia River Basalt Group (from Smith, 1988b). 
The olympic-wallowa lineament is a northwest-trending zone of folds and faults extending from the Wallowa Mountains in Oregon to the Olympic Peninsula in Washington (Raisz, 1945). Within the field area the Olympic Wallowa lineament is defined by the White River-Little Naches fault zone (Fig. 4; Campbell, 1989; Reidel and others, 1994). This major fault zone extends for $90 \mathrm{~km}$ from Naches to Enumclaw, Washington. South of the Nile basin, the fault zone forms a synclinal structure extending from Naches, Washington, northwest along the Little Naches River. Several less developed southwesttrending folds (i.e. the Nile Creek syncline) split off the White River-Iittle Naches syncline in a southwesterly direction into the study area. These smaller structures are possibly affected by the Rimrock Lake inlier and Bumping Lake pluton to the south, as illustrated by a possible northeastplunging anticline found along the Bumping River (Fig. 4).

The Edgar Rock dome, located south of the Naches River near Cliffdell (Fig. 2), is also a major structural feature within the study area. The Edgar Rock dome is a volcanic center which has been subsequently domed by compression (Carkin, 1988). During the late oligocene development of the dome the principal direction of compression in the basin was southwest-northeast (Carkin, 1988). This compression is indicated by the dipping of Fifes Peaks units east and southeast of Old Scab Mountain. Subsequent Miocene north- 

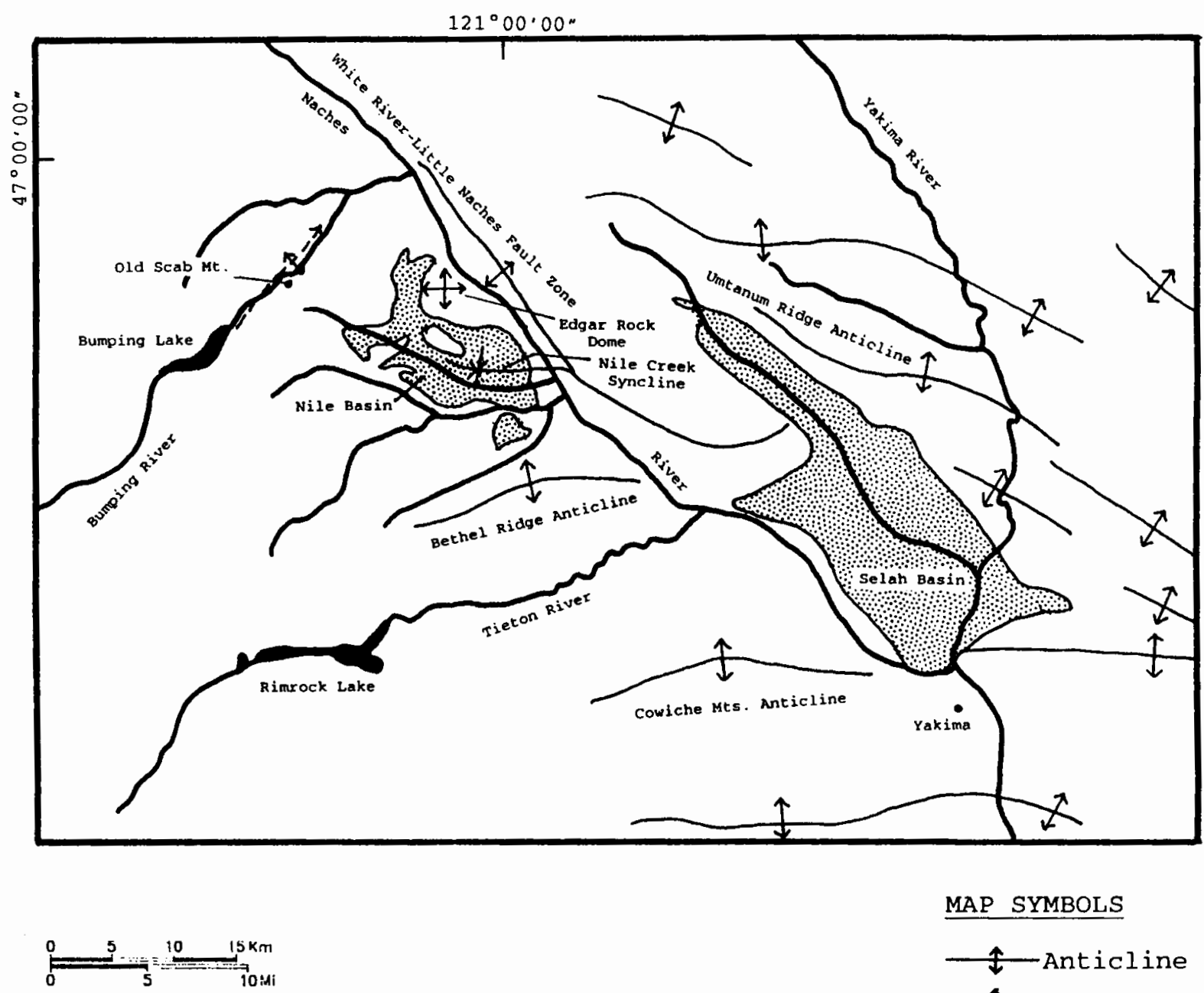

MAP SYMBOLS

$\uparrow$ Anticline

- -

$*$ Syncline
$\uparrow$ Dome

Figure 4 - Structural map of the study area in Washington. 
south compression changed the regional strike to a more eastwest direction, as observed in Ellensburg strata in the Nile basin.

The Nile basin is defined by the Nile Creek syncline which is bounded to the northeast by Edgar Rock dome, and to the south-southwest by the east dipping hogback of Windy Ridge and the gently dipping north flank of the Bethel Ridge anticline. The Nile Creek syncline wraps around the dome in a northwesterly direction and eventually shallows immediately south of the Naches River. Deposits of the Ellensburg Formation within the Nile basin are thickest along the valley walls of Nile Creek, south of the Edgar Rock dome. 


\section{FIELD METHODS}

Field work was conducted in the summer of 1994. Forest roads, trails, and cross country transects were walked to achieve maximum land coverage. All mapping was plotted on $1: 24,000$ scale U.S. Geologic Survey (USGS) base topographic maps (Quadrangles: Old Scab Mtn., Cliffdell, Timberwolf Mtn., and Meeks Table). Detailed descriptions of stratigraphy, unit contacts, and lithology were performed throughout the study area. Samples were collected of dacitic intrusive units, pyroclastic tuffs, and dacitic clasts within laharic and sedimentary units. These samples were labeled and recorded for location, stratigraphic position, and unit origin.

\section{ANALYTICAI METHODS}

$\mathrm{X}$-ray fluorescence (XRF) was used to identify major and trace elemental concentrations of 120 samples within the Nile basin and adjacent areas. Instrumental neutron activation analysis (INAA) was used to identify major, trace and rare earth elemental concentrations of 43 samples within the Nile basin and adjacent areas. All analytical results, brief sample descriptions, and sample locations are summarized in Appendices A-D. 
$X$-ray fluorescence $(X R F)$ is one of the most widely used analytical techniques for analyzing rock samples for major elements and trace elements (Wilson, 1989). Instrumental neutron activation analysis (INAA) analyzes for trace elements and rare earth elements (REE). The use of both techniques enabled determination of concentrations of 30 major and trace elements, and comparison of 13 elements between techniques.

All XRF analyses were conducted at the Washington state University (WSU) GeoAnalytical Laboratory in Pullman, Washington. Analyses were conducted using an Automatic Rigaku 3370 Spectrometer operated by Dr. Peter Hooper and Diana Johnson (WSU). All samples were prepared at Washington State University using procedures specified by Hooper and others (1993). Precision was determined by checking instrumental performance against two standards (BCR-P, GSP-1). Standards were run routinely every 28 samples.

All INAA analyses were conducted at Portland state University using a high-purity gamma detector and an EG\&G ORTEC 92X Spectrum Master Analyzer. Irradiation of samples was conducted for one hour at $250 \mathrm{~kW}$ power in the reactor facility at Reed College in Portland, Oregon. Transportation of irradiated samples to Portland State University was conducted five days after irradiation. First counts were conducted five days after irradiation for detection of short-lived isotopes and second counts were conducted twenty days after irradiation for 
detection of longer-lived isotopes. Due to data storage errors (5/4 inch floppy disk contained bad sectors), second counts were re-conducted for samples 94114 and 94115 thirty-eight days after irradiation. All sample counts were calibrated to the coal fly ash standard and compared to the BCR-1, MAG-1 and JR-1 standards.

Minerals were determined through the examination of standard thin sections using an optical polarizing microscope. Modal mineral concentrations were determined through pointcounting along a $0.5 \mathrm{~mm} \times 0.5 \mathrm{~mm}$ grid using an automated pointcounter device. 1,000 to 2,000 point-counts per thin section were used to determine modal percentages. 


\section{STRATIGRAPHY}

Rock units within the Nile basin range in age from early oligocene to late Miocene. These rock units are dominated by tuffs, lahars, lava flows, intrusions, and fluvial deposits, and show a compositional range from basalt to rhyolite (Plate 1).

Andesitic undifferentiated Tertiary volcanics exposed along Highway 410, approximately $5 \mathrm{~km}$ southeast of Cliffdell, Washington, are the oldest rock units found within the study area. The oldest named stratigraphic unit consists of early oligocene volcanic rocks of the Ohanapecosh Formation. The Bumping River tuff (late Oligocene) unconformably overlies the Ohanapecosh Formation; it is rhyolitic in composition 175 to $778 \mathrm{SiO}_{2}$ ) and erupted from the Mount $\mathrm{Aix}$ caldera south of the study area (Hammond and others, 1994; King, 1994). The Fifes Peaks Formation (late oligocene to early Miocene) overlies Bumping River tuff and is composed of an assemblage of lava flows and volcaniclastic deposits. The Columbia River Basalt Group and the Ellensburg Formation are Miocene units which unconformably overlie the Fifes Peaks Formation. The Columbia River basalt flows erupted from dike swarms originated in the Columbia Plateau in southeastern Washington (Wright and others, 1989). The Ellensburg Formation is composed of dacitic volcaniclastic and sedimentary deposits and is 
possibly derived from dacite porphyry intrusive centers located west of Nile basin. The largest of these dacite centers is old Scab Mountain located along the western boundary of the basin.

\section{UNDIFFERENTIATED TERTIARY VOLCANICS}

Andesitic volcanic rock, consisting of massive to fractured lava flows, volcanic breccias and volcaniclastic sediments, unconformably underlie the Fifes Peak Formation along the northeast part of the study area. These deposits show evidence of hydrothermal alteration, which include almost complete replacement of pyroxene and hornblende phenocrysts to carbonate and chlorite, replacement of groundmass by carbonate, chlorite and minor zeolites, and carbonate and quartz veining (Carkin, 1988).

Correlation of the undifferentiated Tertiary volcanics is difficult due to the degree of hydrothermal alteration. Warren (1941) correlates the volcanic deposits to strata associated with the Ohanapecosh Formation. Carkin (1988) additionally argues that the deposits may be part of the Timberwolf Mountain facies of the ohanapecosh Formation, mapped by Shultz (1988). However, final correlation has not been determined. 
OHANAPECOSH FORMATION

The Ohanapecosh Formation is the oldest formational unit within the study area, ranging in age from 28 to $36.4 \mathrm{Ma}$ (Schasse, 1987; Vance and others, 1987). It consists of andesitic lava flows, well-bedded andesitic to dacitic pumiceand lithic-rich tuffs, ash tuffs, and volcaniclastic conglomerates and sandstones (Fiske and others, 1963; Winters, 1984; Vance and others, 1987). It is exposed below the Fifes Peaks Formation along Rattlesnake Creek and the eastern slopes of Bumping River north of old Scab Mountain (Plate 1). These Ohanapecosh deposits belong to the Wildcat Creek beds (Hammond, personal communication, 1994) which are well-bedded andesitic to dacitic volcaniclastic rocks. They are the finer grained, more distal facies of the Ohanapecosh Formation (Vance and others, 1987).

\section{BUMPING RIVER TUFF}

The Bumping River tuff is one of at least three rhyolitic tuff units which is thought to have erupted from vents within the Mount Aix caldera (Hammond and others, 1994; King, 1994). This tuff was previously considered to be part of the tuff of Rattlesnake Creek (Schreiber, 1981; Vance and 
others, 1987), but its distinctive chemical signature and proximity to the caldera separates it from other local tuff units (Hammond and others, 1994; King, 1994).

The Bumping River tuff is a pale brown to white, quartzplagioclase rhyolitic tuff which dates between 25-28 Ma (Schreiber, 1981; Vance and others, 1987). It consists of interbedded indurated pyroclastic flows, air-fall tuffs, and fluvially reworked volcaniclastic materials. It is exposed along the Bumping River within the study area, north and east of Old Scab Mountain.

\section{FIEES PEAKS FORMATION}

The Fifes Peaks Formation is a volcanic assemblage of basaltic-andesitic to rhyolitic lava flows, tuffs, volcaniclastic tuff breccias, lahars, and sedimentary rocks, of late oligocene to early Miocene in age (Hartman, 1973; Hammond, 1980; Schasse, 1987; Vance and others, 1987; Hammond and Hooper, 1991). The formation was named after the Fifes Peaks stratovolcano-caldera to the north-northwest of the field area (Warren, 1941), but is believed to have been derived as well from the Edgar Rock and Timberwolf Mountain volcanoes (Carkin, 1988; Shultz, 1988). Its strata unconformably underlie the Grand Ronde Basalt and the Ellensburg Formation. 
Within the study area the formation can be divided into two lithologically and structurally distinct groups of rocks separated by a pronounced angular unconformity (Carkin, 1988). Both groups are believed to have erupted from a volcanic center which was located near Edgar Rock and which is now defined by the Edgar Rock dome. The older group is informally named by Carkin (1988) as the Edgar Rock member after the prominent cliff just outside of Cliffdell, Washington. This unit is defined by an extensive system of radial dikes which centers at the dome. The younger group is informally named the Nile Creek member and lacks the radial dikes seen in the Edgar Rock member.

Exposed thickness of both members near Edgar Rock is at least $1,800 \mathrm{~m}$. Cliff exposures can be seen along the Naches River near Cliffdell, along the Nile Creek, on the eastern slopes of the Bumping River, and along Rattlesnake Creek.

\section{COLUMBIA RIVER BASALT GROUP}

The Columbia River Basalt Group unconformably overlies the Fifes Peaks Formation and is interbedded with and underlies the Ellensburg Formation. Within the study area the basaltic lava flows are between 15 to $16 \mathrm{Ma}$ and represent magnetically normal flows of the Grande Ronde Basalt (Bentley, 1977; Reidel and others, 1994). Successively younger flows, represented by the Wanapum Basalt and Saddle Mountains Basalt of the Columbia River 
Basalt Group, are exposed within basins to the east (Selah, Yakima and Topenish basins) of the field area. These younger flows pinched out towards the west and are not exposed in the Nile basin.

Within the field area, Grande Ronde Basalt is dark gray to black aphanitic to sparsely porphyritic tholeiitic basalt with flow thicknesses up to $30-40 \mathrm{~m}$. Jointing is columnar to wavy columnar to hackly. Exposed thicknesses along the Iittle Naches River reach up to $300 \mathrm{~m}$, but can be less than $10 \mathrm{~m}$ thick where the flows onlap onto the topographically higher basin margins. Along fault zones and structurally deformed flow contact zones the basalt can be highly brecciated with angular, 0.5 to $5 \mathrm{~cm}$ clasts (Fig. 5).

Grande Ronde flows are presently confined within topographic basins. The locations of these basins were controlled primarily by synclinal structural components of the Olympic-Wallowa lineament. Within the Nile basin the Nile Creek syncline is the principal structural component which controls the distribution of the Grande Ronde flows. Along the basin margins, the flows become thinner and commonly pinch out. The total number of flows also become less along the basin margins. Near Rattlesnake Creek the flow thicknesses are the greatest and as many as four Grande Ronde flows have been identified. Along 
the basin margins to the north, closer to the Edgar Rock dome, the number of flows is reduced and pinch out along Nile Creek (Figs. 1 and 2 ).

Flow-filled erosional valleys are common and are often defined by isolated islands of Grande Ronde Basalt surrounded by primarily older rock assemblages. These valleys are typically narrow, relatively shallow, and rarely extend farther than about $5 \mathrm{~km}$ from the main body of the flow.

\section{ELLENSBURG FORMATION}

All sedimentary units which are interbedded within and which overlie the Columbia River Basalt Group in the western Columbia Plateau in Washington are commonly referred to as the Ellensburg Formation (Swanson and others, 1979). These deposits are primarily confined to the Nile, Selah, Yakima, Ellensburg, Moxee, and Toppenish basins, with lesser exposures in the Umatilla basin (Smith and others, 1989a). Other volcanic sedimentary units in the Pacific Northwest which interbed with the Columbia River Basalt Group and which are not defined as the Ellensburg Formation are the Latah Formation of Washington and Idaho, and the Simtustus Formation of central Oregon (Swanson and others, 1979; Smith, 1986; Smith, 1991b). Both formations are lithologically and 
temporally related to the Ellensburg, and show similar depositional processes. However, their eruptive sources are different.

Lower Stratigraphic Control

Defining the base of the Ellensburg Formation has been a significant stratigraphic problem in the past (Mackin, 1961; Schmincke, 1964). Mackin (1961) originally placed the lower boundary of the Ellensburg Formation at the top of the Priest Rapids Member of the Wanapum Basalt of the Columbia River Basalt Group (Fig. 3). Mackin (1961) defined the deposits stratigraphically below the Priest Rapids basalt as being sedimentary components of the Yakima Basalt Subgroup. However, Schmincke (1964) argued that some of these interbedded sediments, such as the Vantage Member, becomes indistinguishable from the main mass of Ellensburg deposits where the Priest Rapids Basalt pinches out to the west. Schmincke (1964) places the base of the Ellensburg Eormation at the top of the Grande Ronde Basalt.

This problem arises once again within the Nile basin. Stratigraphically below the Grande Ronde Basalt is a series of volcaniclastic sedimentary units of similar lithology and depositional styles to those of the main mass of Ellensburg deposits which overlie Grande Ronde Basalt. Where Grande 
Ronde Basalt thins and pinches out, these lower sediments are indistinguishable from the overlying Ellensburg Formation.

Carkin (1988) mapped some of these deposits along Nile Creek as belonging to the Nile Creek Member of the Fifes Peaks Formation. Using the fission-track dating method, he dated one pyroclastic deposit (Carkin's sample \#115, Fig. 6) and obtained an age of $23.3 \pm 2.4 \mathrm{Ma}$. This age falls within the upper age range of the 24 to 19.5 million year old Nile creek member of the Eifes Peaks Eormation (Carkin, 1988). However, structural and stratigraphic correlations do not support this interpretation. The bedded orientation of the unit dated by Carkin (1988) dips to the north-northeast at approximately $5^{\circ}$, whereas, adjacent Nile Creek beds dip from 22 to $75^{\circ}$ to the south-southeast. The $5^{\circ}$ north-northwest dip is inconsistent with all bedding orientations of the Nile creek units found southwest of the Edgar Rock dome; whereas the orientation is consistent with nearby Ellensburg deposits which are younger than the deformation which formed the dome. This relationship indicates a younger age for these volcanic deposits.

Based on their lithologic and depositional similarities, this author argues that the volcaniclastic and sedimentary units which underlie the Grande Ronde Basalt and unconformably overlie the Fifes Peaks Formation should be classified as part of the Ellensburg Formation. As a result, hereinafter, this author refers to volcaniclastic and sedimentary deposits which 


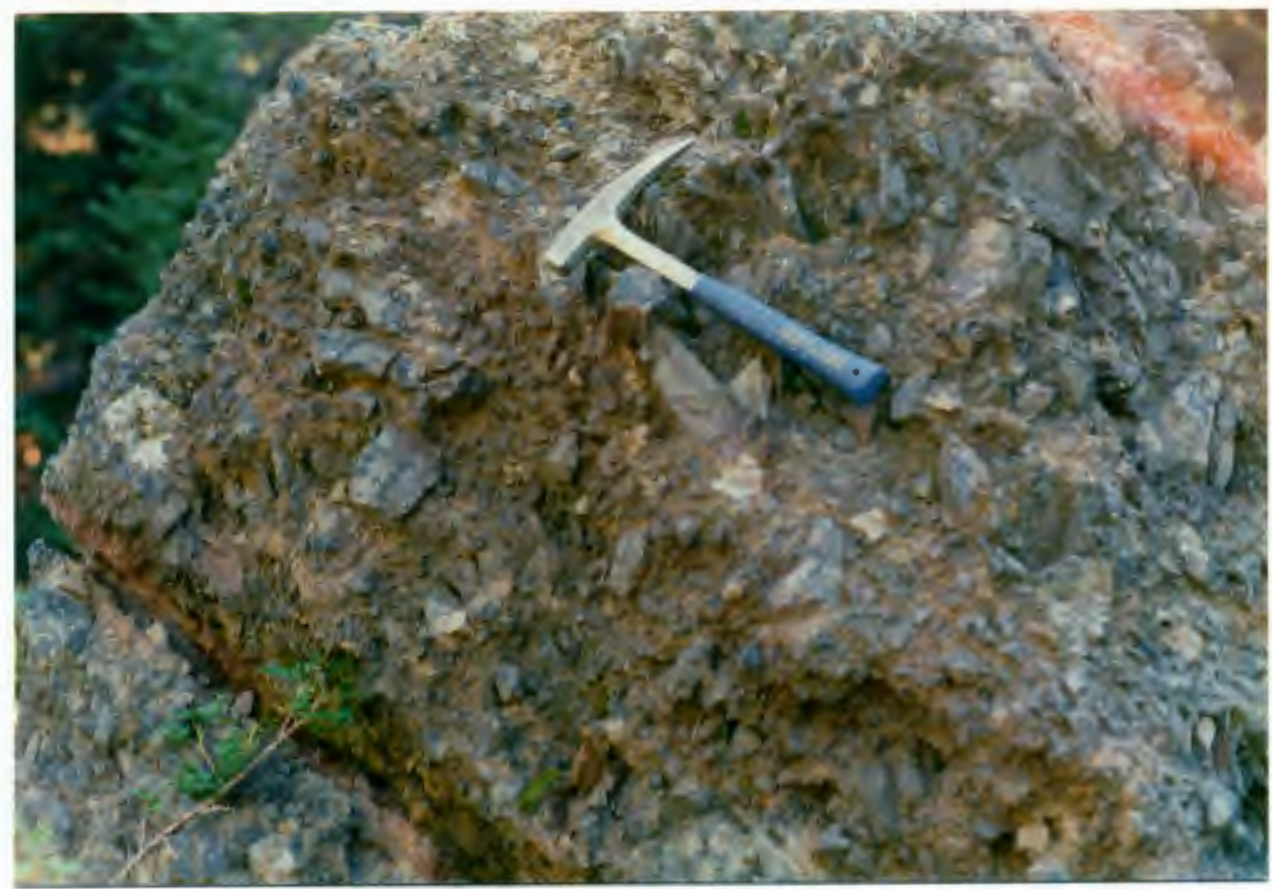

Figure 5 - Fault brecciated basalt of the Columbia River Basalt Group (CRBG) exposed along NF trail \#975, southeast of old Scab Mountain.

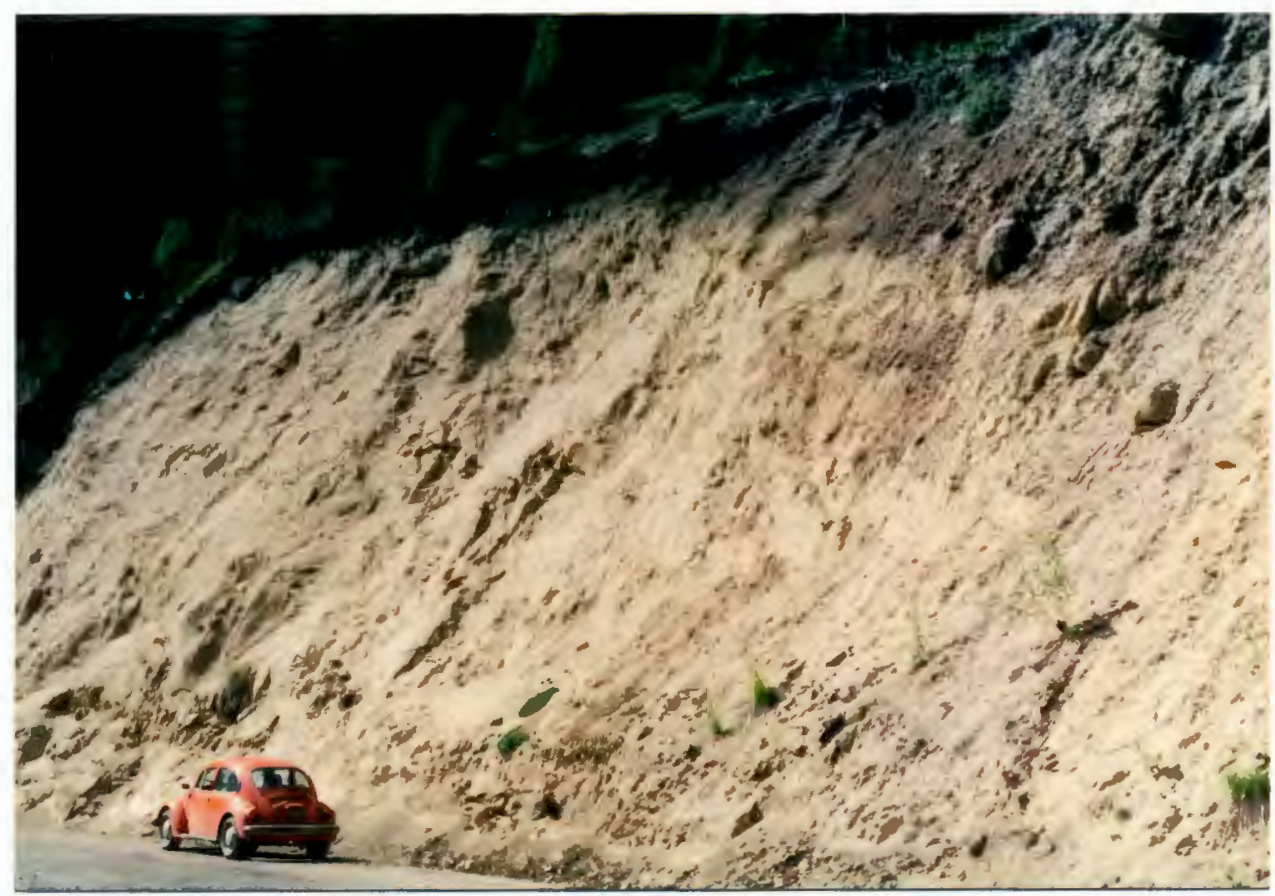

Figure 6 - Pyroclastic flow deposits within the lower Ellensburg Formation exposed along NF local road \#1605. 
underlie Grande Ronde Basalt as the lower Ellensburg Formation, and those volcaniclastic and sedimentary deposits which overlie Grand Ronde Basalt as the upper Ellensburg Formation.

Geologic Age

Age determinations of Ellensburg Formation which stratigraphically overlies Grande Ronde Basalt range from $11.28 \pm 0.37$ to $7.0 \pm 1.0 \mathrm{Ma}$ (Smith, 1989). The oldest age was obtained by Smith (1989; K-Ar), of a coarse-grained, volcaniclastic Ellensburg unit which rests unconformably on Grande Ronde Basalt along Rattlesnake Creek. The youngest age was reportedly obtained by B. N. Bjornstad (written communication reported in Smith and others, 1989) and was an apatite fission-track age determination of a sample collected from the top of the Rattlesnake Creek section. Deposits represented by the Selah and Vantage Members of the Ellensburg Eormation (Fig. 3, 12 to $15.6 \mathrm{Ma}$ ) are generally confined to basins to the east and not found within the Nile basin. One fission-track age determination for the lower Ellensburg Formation was obtained by Carkin (1988). Carkin (1988) obtained an age of $23.3 \pm 2.4$ Ma for a pyroclastic flow sample collected near Nile Creek. However, as discussed above, this age is suspect. The lower Ellensburg Eormation is probably between 16-19.5 Ma, which represents the time 
interval between the youngest deposits of the Nile Creek Member of the Fifes Peaks Formation and the oldest flows of the Grande Ronde Basalt within the Nile basin.

Thin sedimentary interbeds which separate some individual flows of the Grande Ronde Basalt may also be part of the Ellensburg Formation (Fig. 3), and would, therefore, date from 16 to $15.6 \mathrm{Ma}$. However, little work has been done to categorize or correlate these sediments to any known geologic unit. Although, no sedimentary interbeds have been mapped within the field area, thick paleosol interbeds have been preliminarily mapped by this author north-northwest of the field area, northeast of Little Naches River.

\section{Stratigraphy}

The Ellensburg Formation consists of interstratified light-gray to pale-brown dacitic lahars, pyroclastic flows and airfall tuffs, conglomerates, volcanic sandstone, and mudstones. At least one dacitic lava flow is present in the Nile basin and is exposed approximately $14 \mathrm{~km}$ east of Old Scab Mountain. Within the Nile basin, the Ellensburg Eormation can be divided into volcaniclastic and epiclastic types. Volcaniclastic materials are any fragmental aggregate that was generated through volcanic processes (Cas and Wright, 1987). These materials include tuffs, lahars, and volcanic debris avalanche deposits. Epiclastic materials are deposits or rocks that were 
produced by normal surface fragmentation processes, such as weathering, physical abrasion, and gravitational collapse (Cas and Wright, 1987). These materials include landslide, eolian, and fluvial deposits.

The greatest preserved thickness of the Ellensburg deposits are within synchronously formed basins (Smith, 1991b). However, within the Nile basin the Ellensburg Eormation is largely confined within one main synclinal basin (Nile Creek syncline) which is bounded to its northeast by the Edgar Rock dome. This synclinal basin begins near the mouth of the Rattlesnake River and extends northwest toward old scab Mountain.

Along the margin of the basin, the Ellensburg deposits become thinner and outcrops become more sporadic. Where Grande Ronde Basalt flows pinch out, the distinction between the upper and lower Ellensburg becomes subjective. However, geochemical differences between the two units are substantial (see geochemical section) and can separate the two units where Grande Ronde flows are absent.

The majority of the exposed Ellensburg deposits found within the Nile Basin belong to the upper Ellensburg Formation. These deposits are found stratigraphically above the Grande Ronde Basalt within structural lows (Plate 1). Exposures of the lower Ellensburg Formation are found only within a few areas of the basin. Most of the exposed lower 
strata occur at the head of the Nile Creek near the center of the field area (Plate 1). Other deposits can be found along the lower northern slopes of Rattlesnake Creek, west of the intersection of the Naches and American Rivers, and along the northern slopes of the American River where the Bumping River flows into the American River (Plate 1).

Although the upper and lower Ellensburg Formation are lithologically very similar, compositional clast types do differ between the two units. Conglomerate deposits within the lower Ellensburg contain a higher percentage of basaltic and basaltic andesite clasts (60 to 1008 by volume) than dacitic clasts. In contrast, conglomerate within the upper Ellensburg contain predominately dacitic clasts, with the percentage of dacitic clasts increasing up section.

Laharic deposits within the lower Ellensburg strata also contain a high percentage of basaltic and basaltic andesite clasts (40 to 1008 by volume). However, the basalt to dacite ratio is extremely variable. Where some laharic deposits contain primarily dacitic clasts, others can be almost exclusively basaltic. This is in contrast to the upper Ellensburg Formation which primarily contains dacitic clasts. Seven stratigraphic sections (sections $A, B, C, D, E, F$, G, and $\mathrm{H}$ ) have been constructed from exposures found within the Nile basin (Fig. 7) and are portrayed in Figures 8 through 15. Figure 16 shows the generalized stratigraphic positions of the 


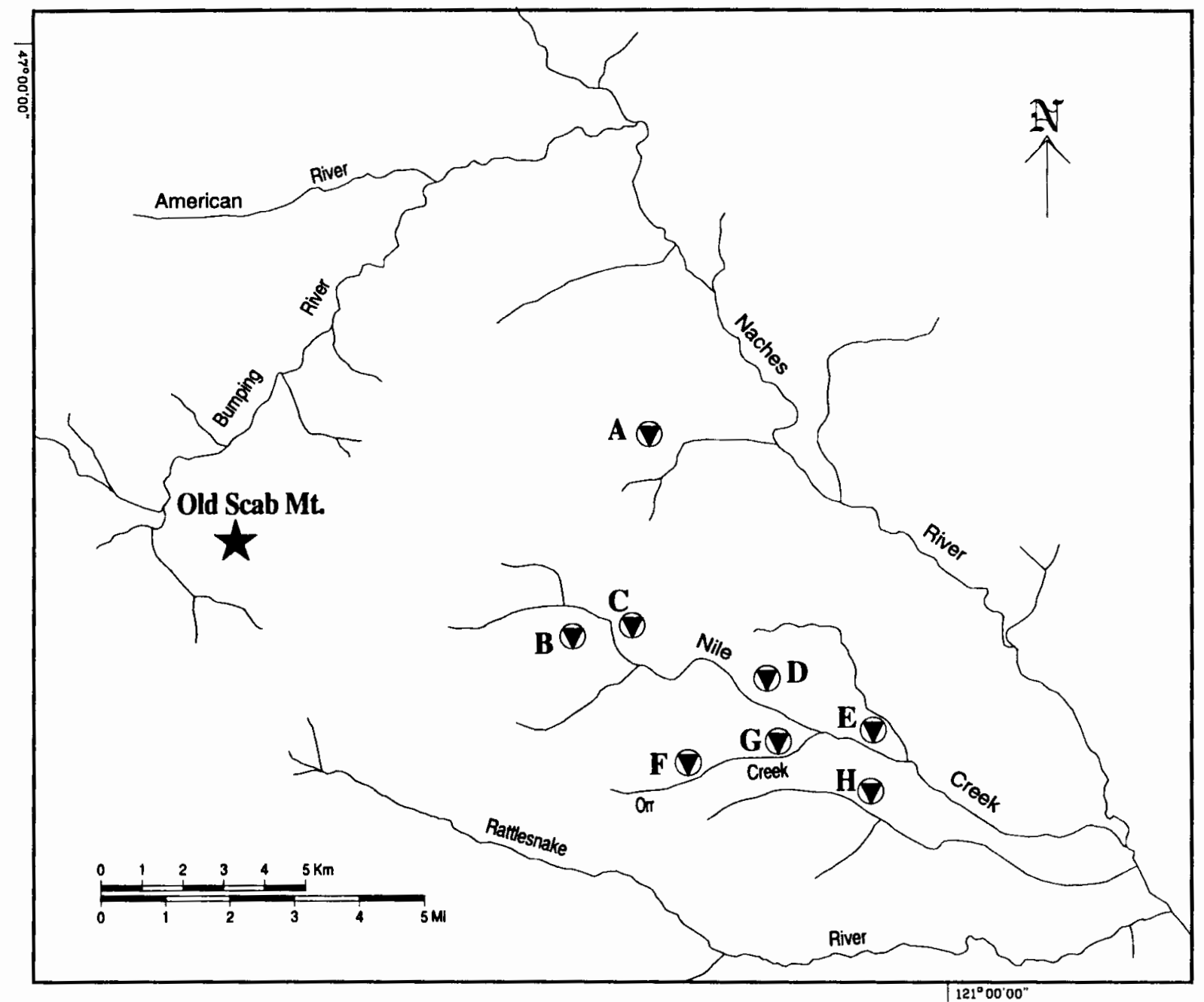

Figure 7 - Location map of the stratigraphic sections shown in Figures 8 through 15. 


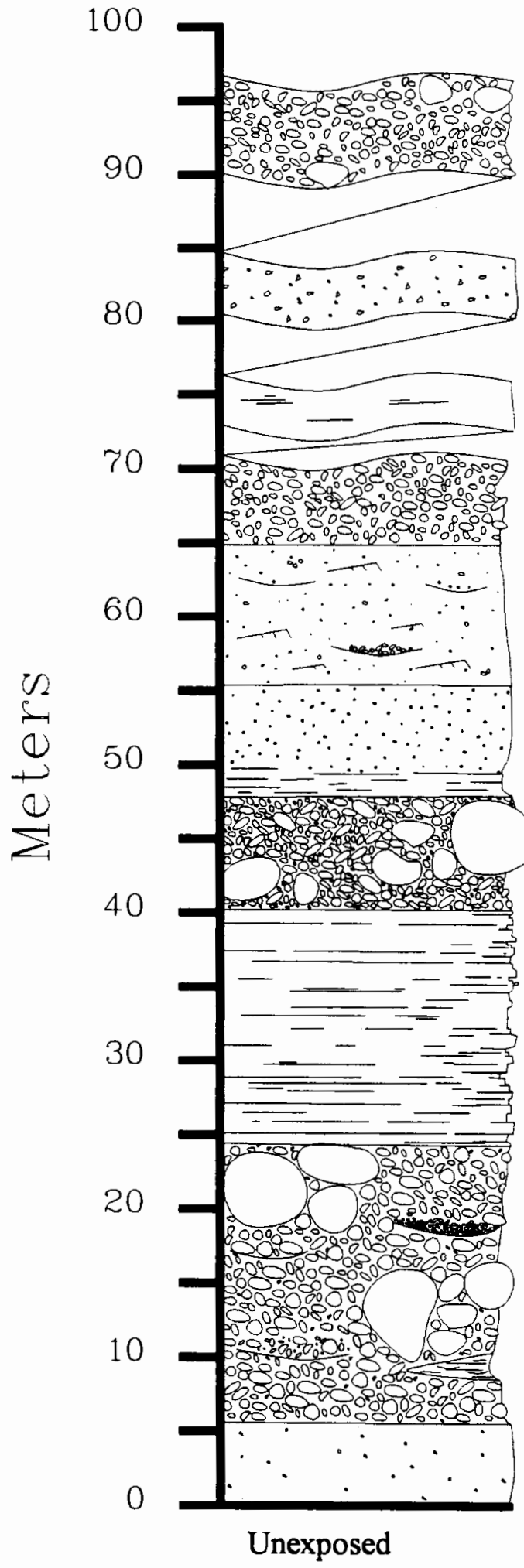

Conglomerate, clast supported, massive, poorly sorted, with rounded clasts. Clasts: $80-90 \%$ vol., $1 \mathrm{~cm}-0.5 \mathrm{~m}$, avg. $3 \mathrm{~cm}, 60 \%$ basaltic, $40 \%$ dacite.

Lapilli-tuff, air fall, massive, poorly sorted, with angular clasts. Clasts: $40 \%$ vol., $1.4 \mathrm{~mm}$, avg. $2 \mathrm{~mm}, 70 \%$ yellow pumice lapilli, $30 \%$ white pumice lapilli, with $3 \%$ homblende, and ash matrix. (\# 94056)

Sand, coarse-grained, crudely cross-bedded, poorly sorted, angular, $30 \%$ rock fragments, $25 \%$ feldspar, $5 \%$ quartz, $3 \%$ hormblende. (\# 94057)

Conglomerate, clast supported, massive, poorly sorted, with rounded clasts. Clasts. $70 \%$ vol., $1-10 \mathrm{~cm}$, avg. $4 \mathrm{~cm}, 80 \%$ dacite, $20 \%$ basaltic

Pebble gravel, clast supported, massive, poorly sorted, rounded. Clasts: $70 \%$ vol., $1-10 \mathrm{~mm}, 50 \%$ dacite, $50 \%$ basaltic, with lenses of clast supported conglomerate (cobbles: $1-5 \mathrm{~cm}$ ). Matrix: coarse sand, poorly sorted, with angular grains.

Pebble gravel, matrix supported, massive, poorly sorted subrounded. Clasts: $40 \%$ vol., $1-10 \mathrm{~mm}, 70 \%$ dacite, $30 \%$ basaltic. Matrix: medium pumiceous sand, with $5 \%$ pumice and $2 \%$ homblende. Lower $2 \mathrm{~m}$ is planar bedded, mediumgrained pumiceous sand. (\# 94076)

Conglomerate, clast supported, massive, poorly sorted, with rounded clasts. Clasts: $90 \%$ vol., $1 \mathrm{~cm}-1 \mathrm{~m}$, avg. $5 \mathrm{~cm}, 70 \%$ dacite, $30 \%$ basaltic.

Volcanic sand, medium to coarse-grained, pumiceous, planar bedded, normal grading, well sorted, angular. Beds $0.5-3 \mathrm{~cm}$ thick, with $5 \% 0.2-0.5 \mathrm{~cm}$ rock, pumice, and homblende fragments. (\# 94075)

Conglomerate, clast supported, cut and fill structures, poorly sorted, with rounded clasts. Clast: $1 \mathrm{~cm}-1.5 \mathrm{~m}$, avg. $8-10 \mathrm{~cm}$, $70 \%$ dacite, $30 \%$ basaltic. With interbedded coarse-grained pumiceous sand and ash. (\# 94074)

Lapilli-tuff, pyroclastic flow, crudely stratified, poorly sorted, with angular clasts. Clast: $25 \%$ white pumice lapilli (1 mm$2 \mathrm{~cm}$ ). (\# 94073)

Figure 8 - Stratigraphic section " $A$ " of the upper Ellensburg Formation. 


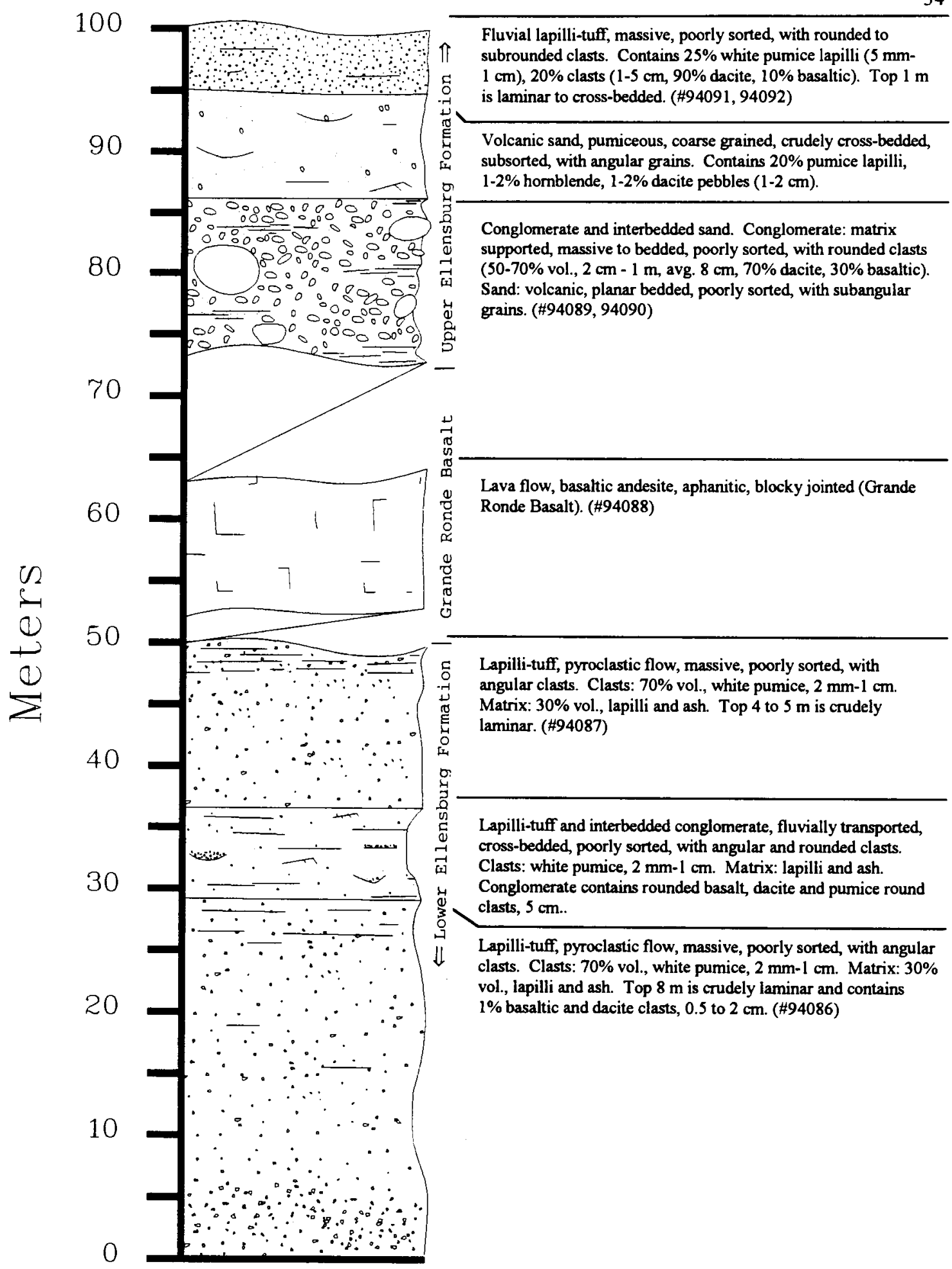

Eigure 9 - Stratigraphic section " $B$ " which includes the upper Ellensburg Formation, Grande Ronde Basalt and the lower Ellensburg Formation. 


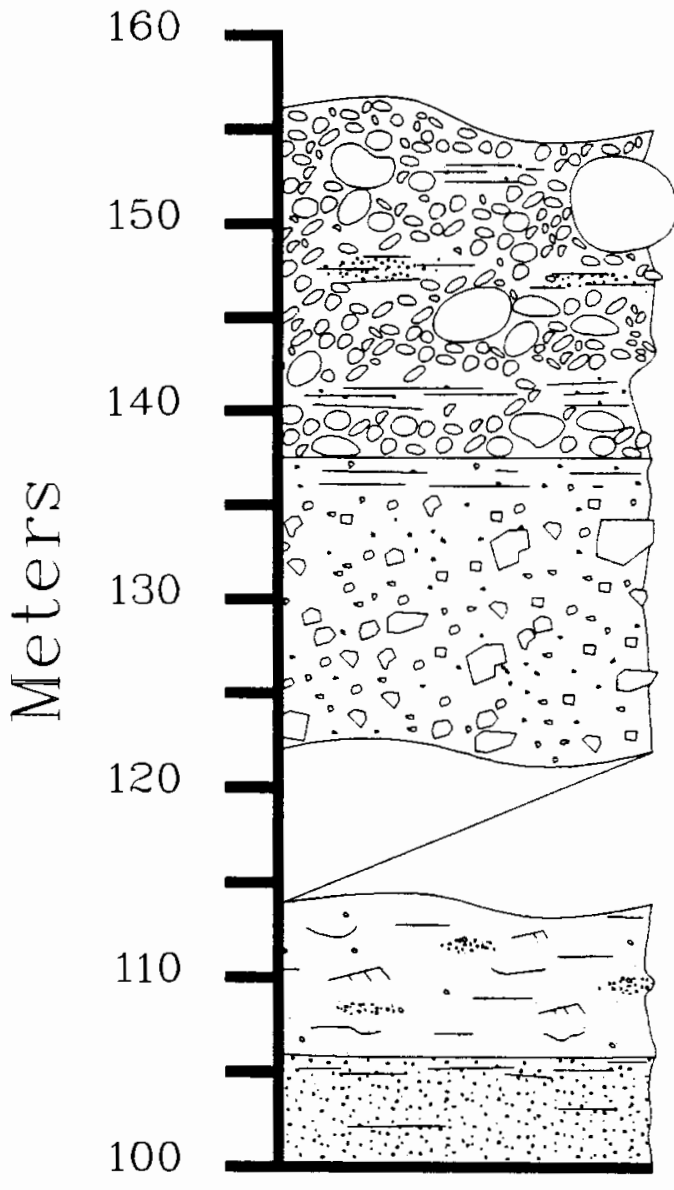

Conglomerate and pebbly sand, interbedded. Conglomerate: clast supported, massive to bedded, poorly sorted, with rounded clasts ( $1 \mathrm{~cm}-1 \mathrm{~m}$, avg. $5 \mathrm{~cm}, 100 \%$ dacite). Sand: volcanic, coarse grained, planar bedded, poorly sorted, with 5 to $20 \%$ dacite pebbles $(1.2 \mathrm{~cm})$. (\$94093)

Tuff-breccia, lahar flow, matrix supported, massive, poorly sorted, with angular clasts. Clasts: $60 \%$ vol., $1 \mathrm{~cm}-0.5 \mathrm{~m}$, avg. 5 $\mathrm{cm}, 60 \%$ dacite, $40 \%$ basaltic. Matrix: fine to medium grained volcanic sand. Top $2 \mathrm{~m}$ is laminar.

Volcanic sand, medium to coarse grained, cross-bedded, poorly to moderately sorted, $100 \%$ pumice lapilli. Contains pebble gravel lenses with clasts $1-2 \mathrm{~cm}, 80 \%$ dacite, $20 \%$ basaltic.

Fluvial lapilli-tuff, massive, poorly sorted, with rounded to subrounded clasts. Contains $25 \%$ white pumice lapilli $(5 \mathrm{~mm}$ $1 \mathrm{~cm}$ ), $20 \%$ clasts ( $1-5 \mathrm{~cm}, 90 \%$ dacite, $10 \%$ basaltic). Top $1 \mathrm{~m}$ is laminar to cross-bedded. ( $\$ 94091,94092)$

Figure 9 - Stratigraphic section "B" continued. 


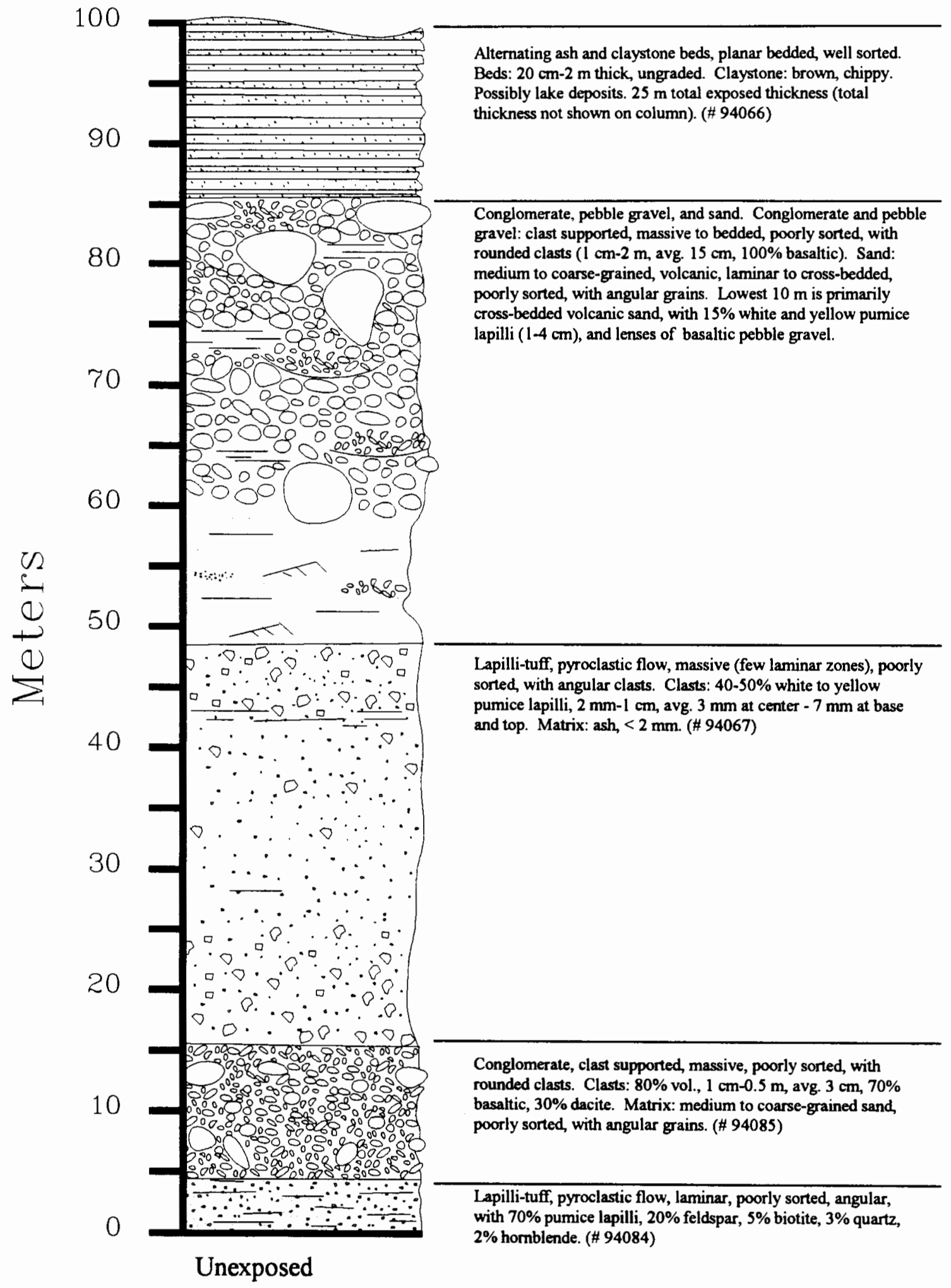
Figure 10 - Stratigraphic section " $C$ " of the upper Ellensburg
Formation. 


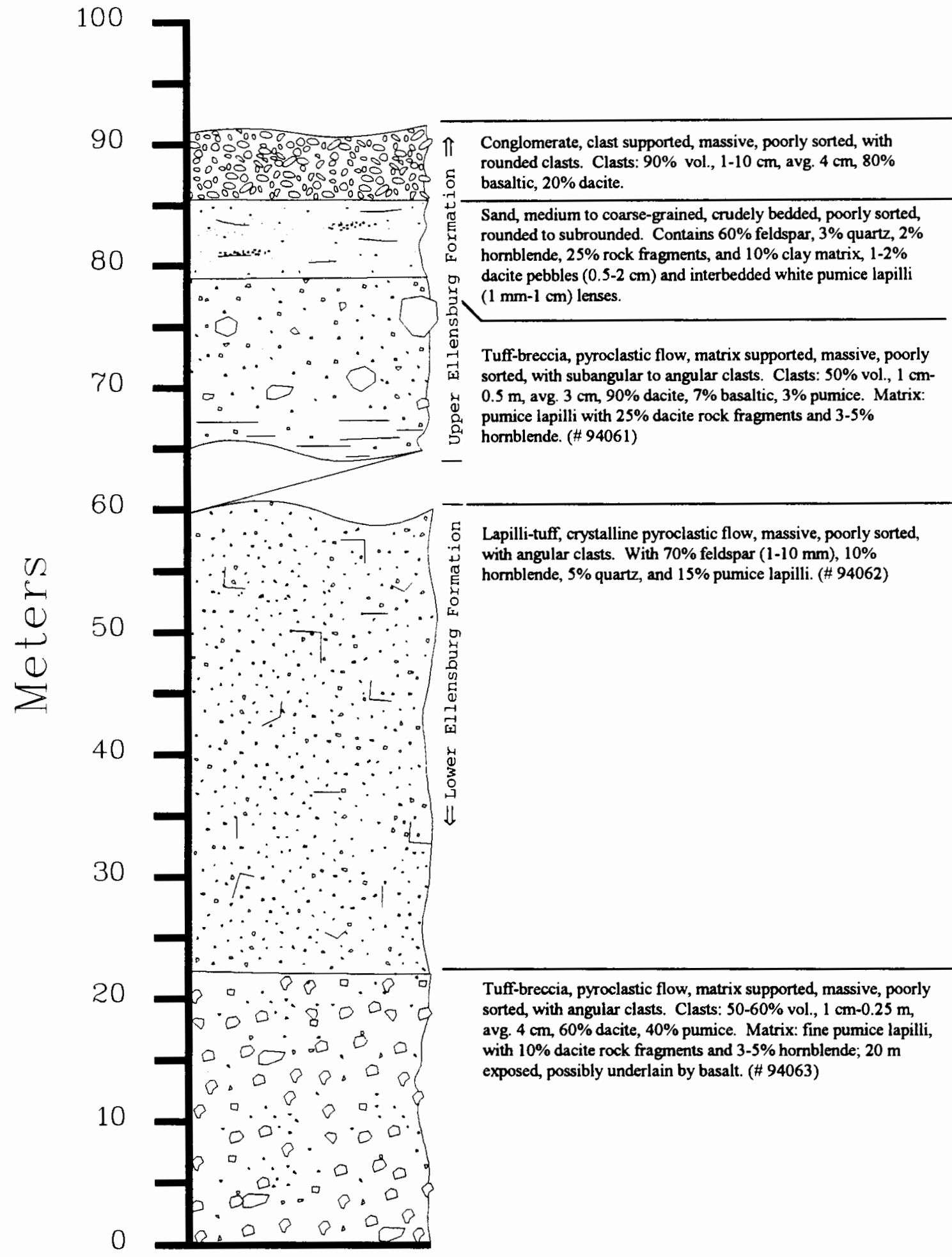

Figure 11 - Stratigraphic section " $D$ " which includes the upper and lower Ellensburg Formation. 


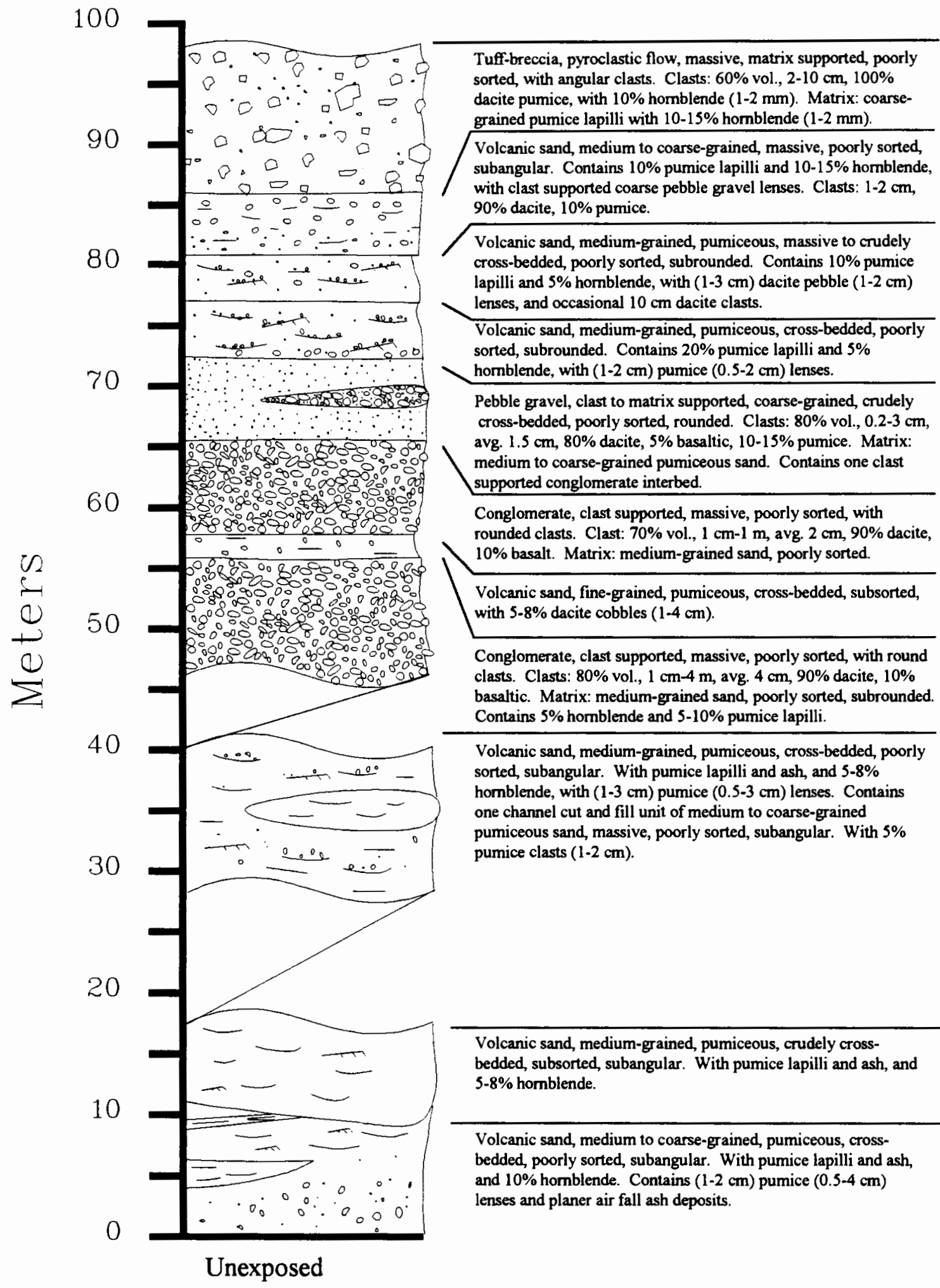

Figure 12 - Stratigraphic section " $E$ " of the upper Ellensburg Formation. 


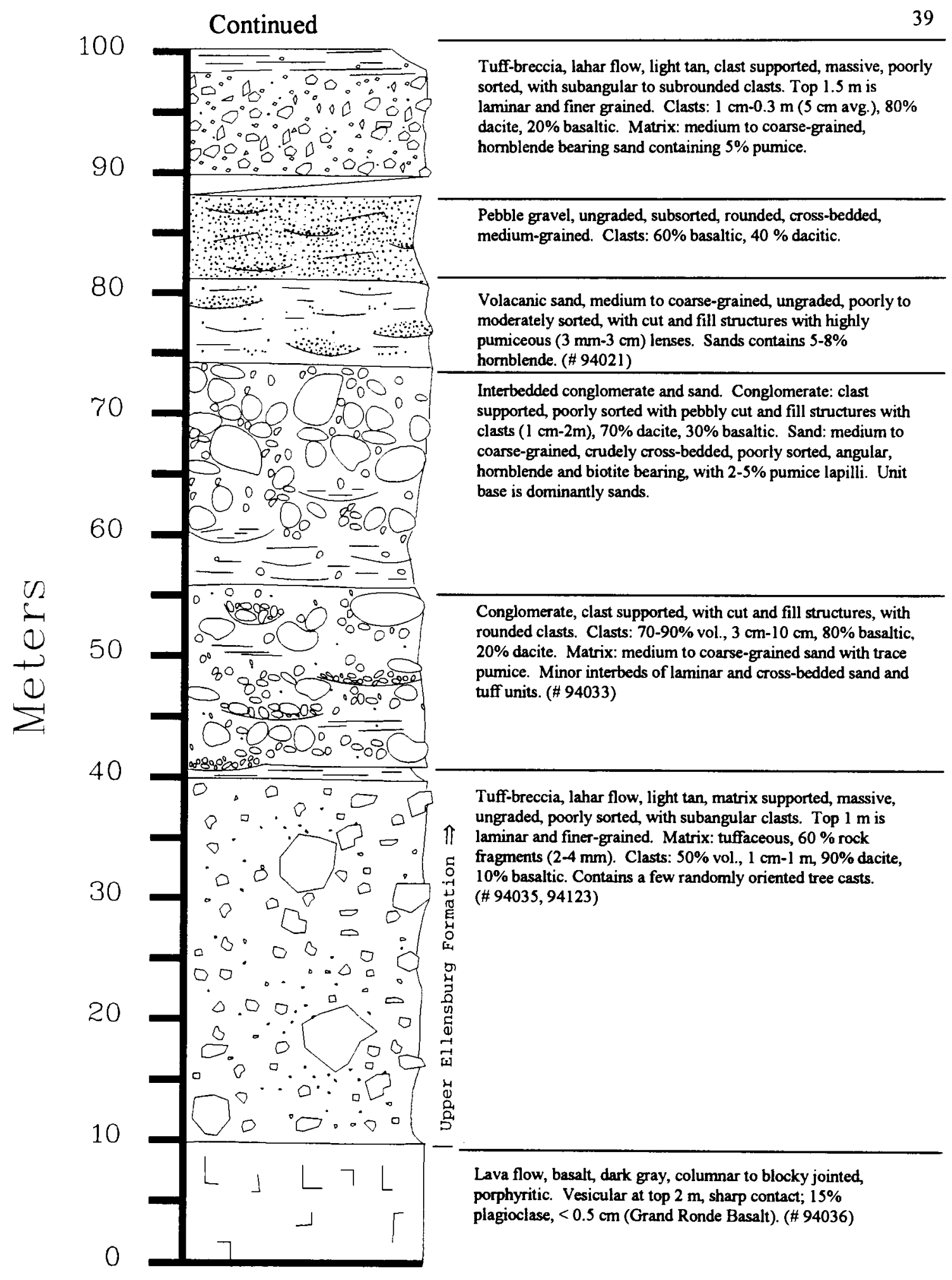

Figure 13 - Stratigraphic section " $F$ " which includes the upper Ellensburg Formation and Grande Ronde Basalt. 


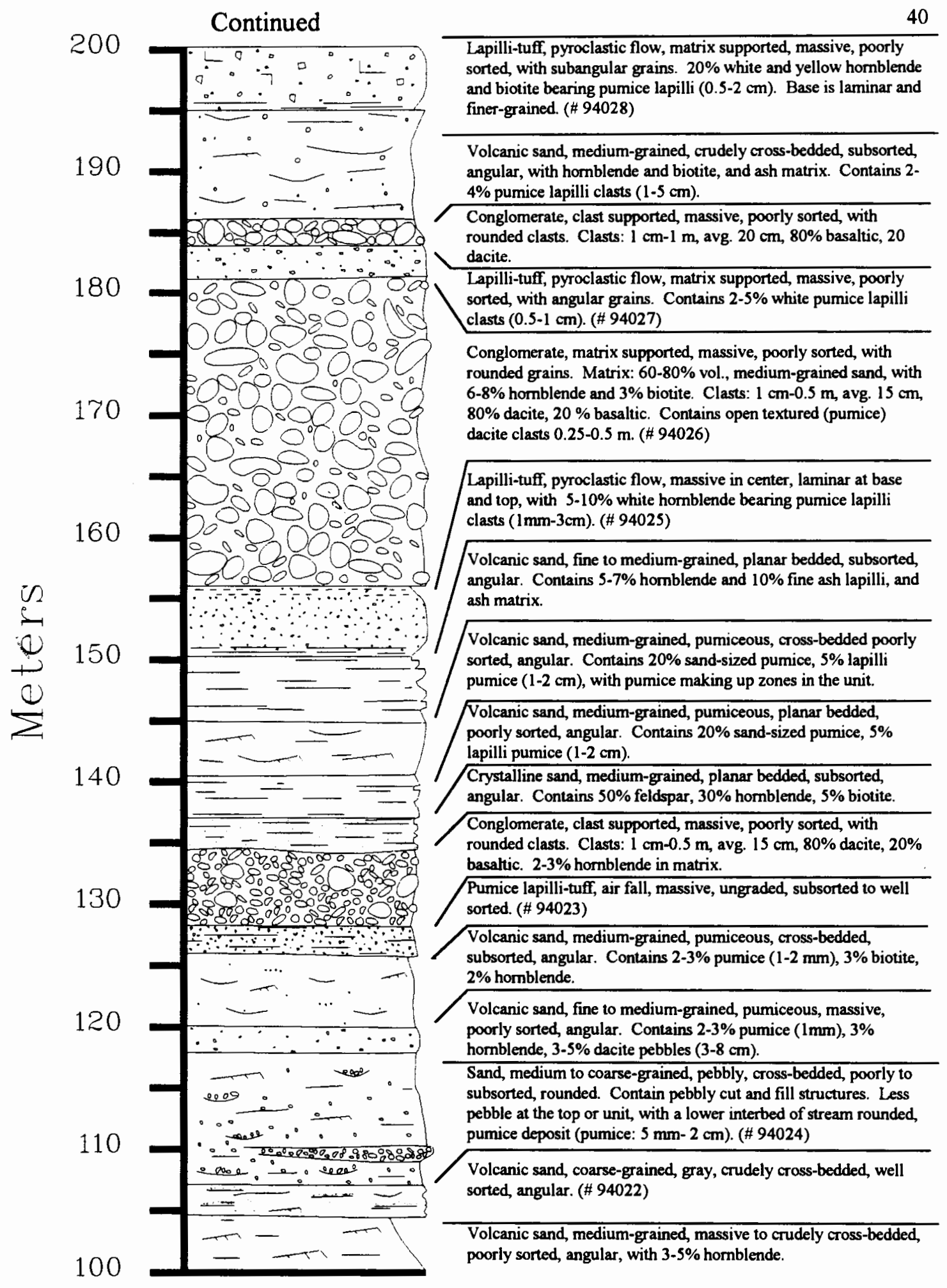

Figure 13 - Stratigraphic section " $F$ " continued. 


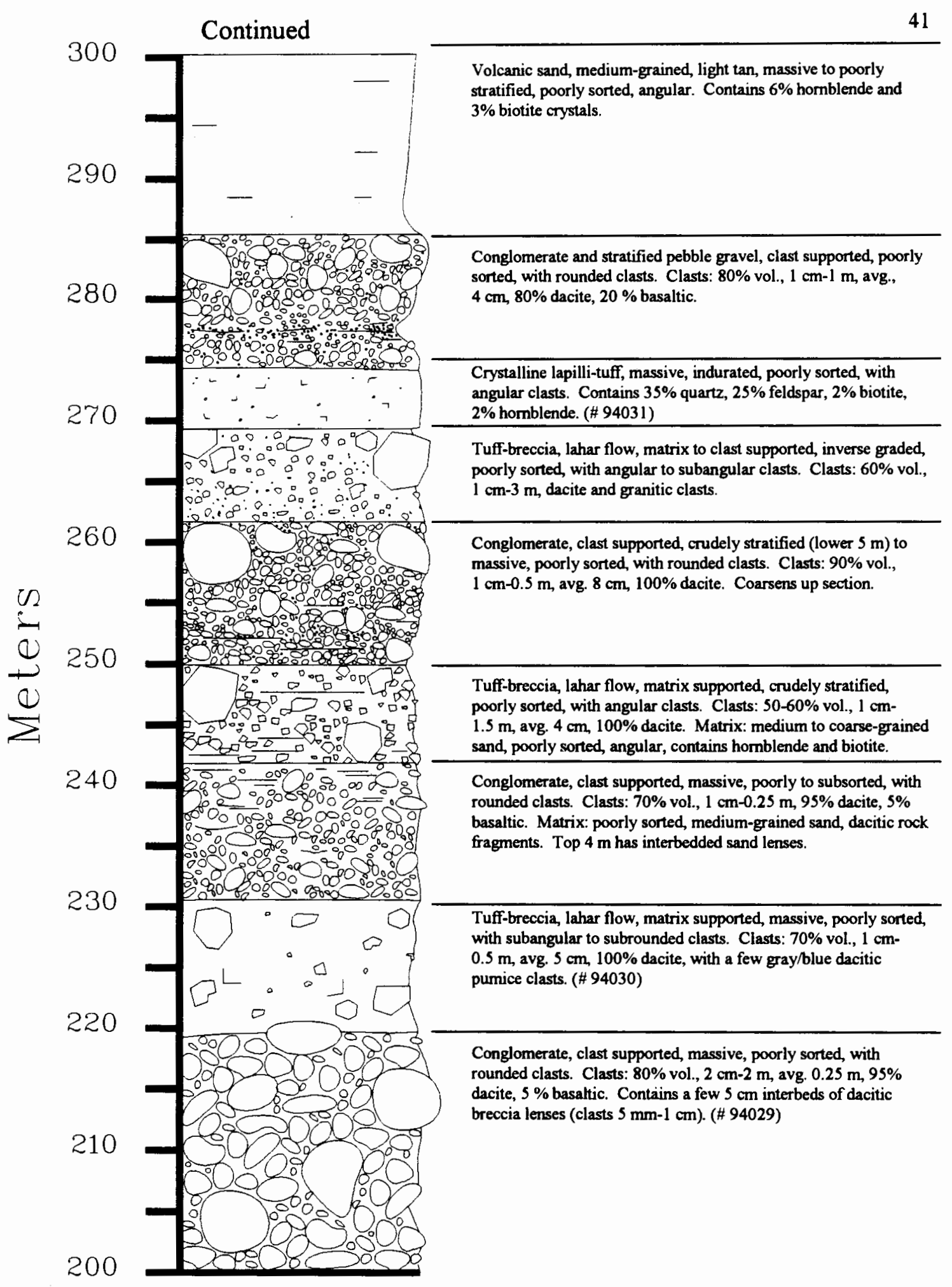

Figure 13 - Stratigraphic section " $F$ " continued. 


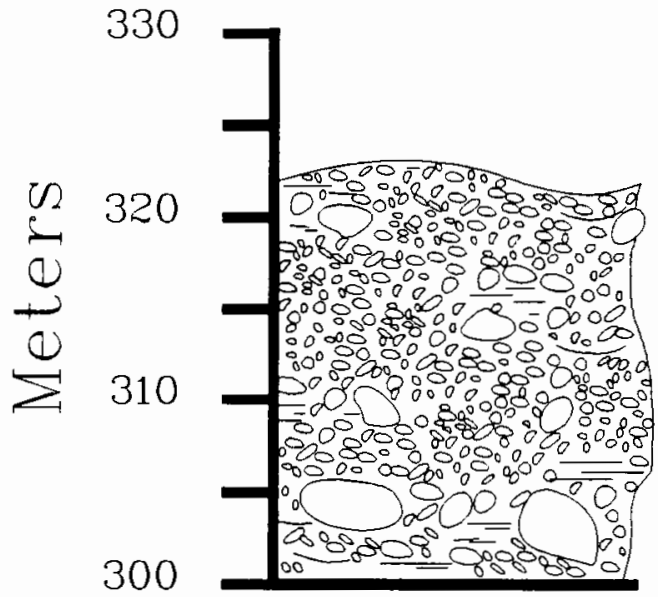

Conglomerate, clast to matrix supported, massive, poorly sorted, with rounded clasts. Clasts $80 \%$ vol., $1 \mathrm{~cm}-1 \mathrm{~m}$, avg. $4 \mathrm{~cm}, 80 \%$ dacite, $20 \%$ basaltic. Contains minor interbeds of medium grained, poorly sorted, angular sands, with $80 \%$ dacitic rock fragments.

Figure 13 - Stratigraphic section "F" continued. 


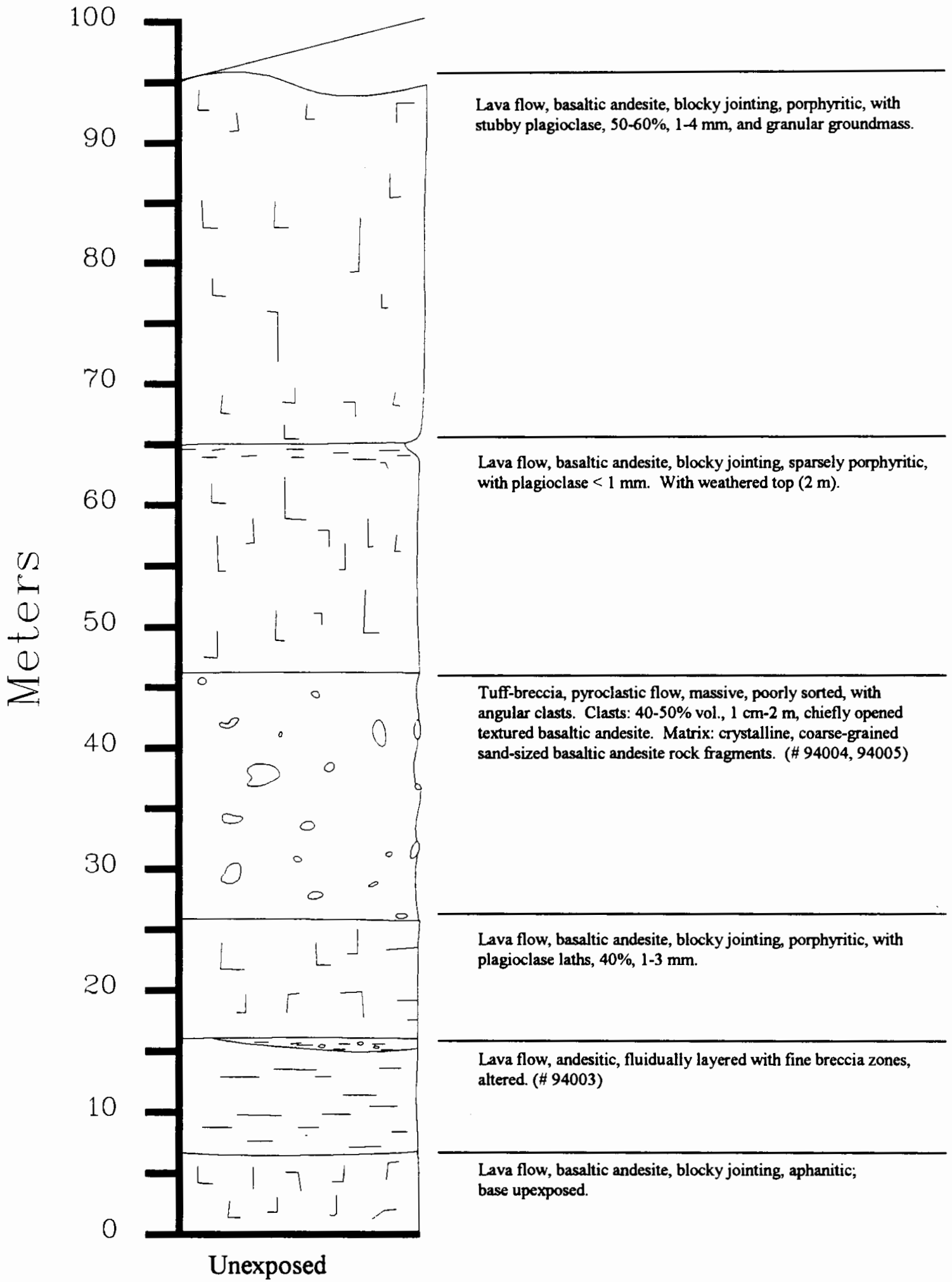

Eigure 14 - Stratigraphic section "G" of the Fifes Peak Eormation. 


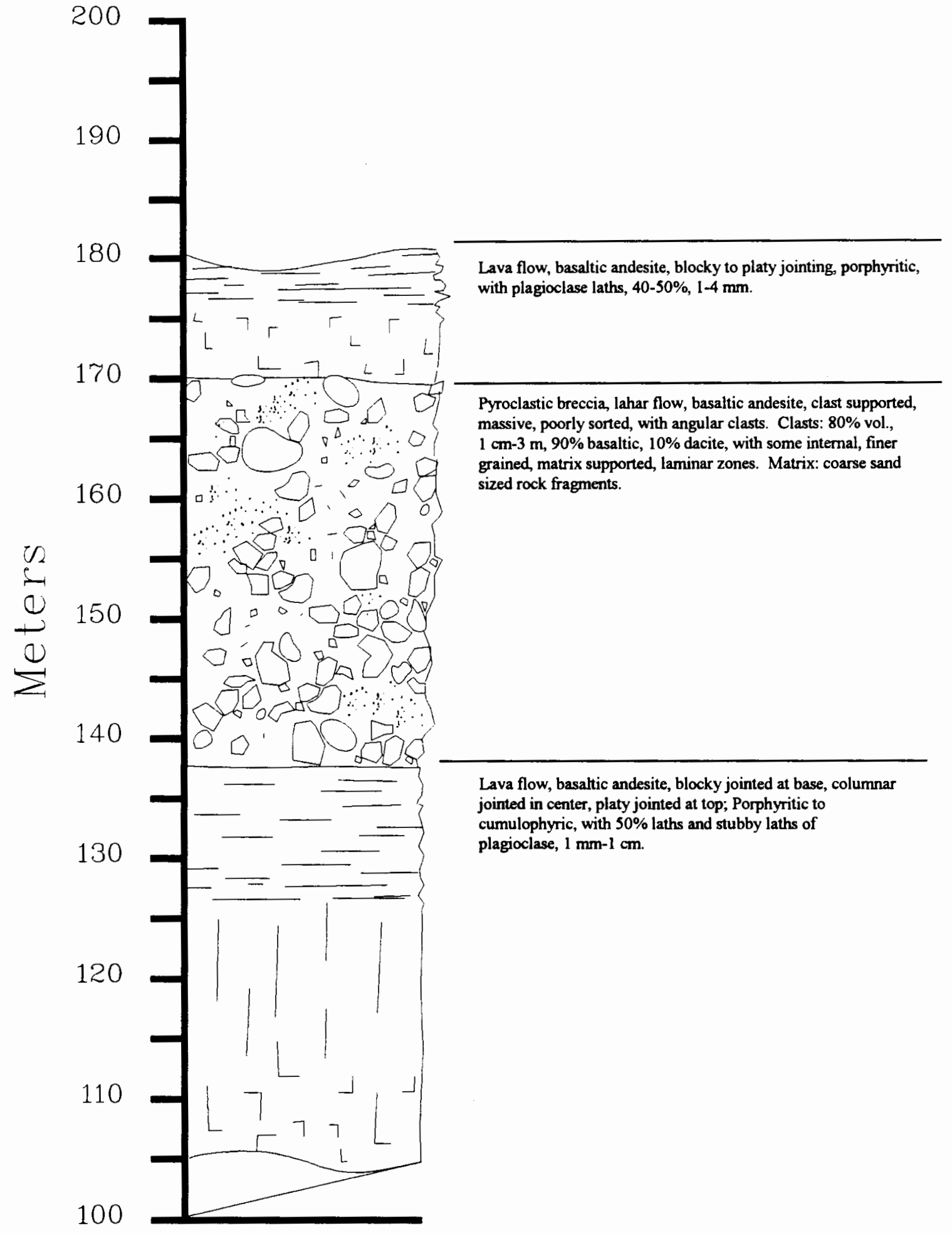

Figure 14 - Stratigraphic section "G" continued. 


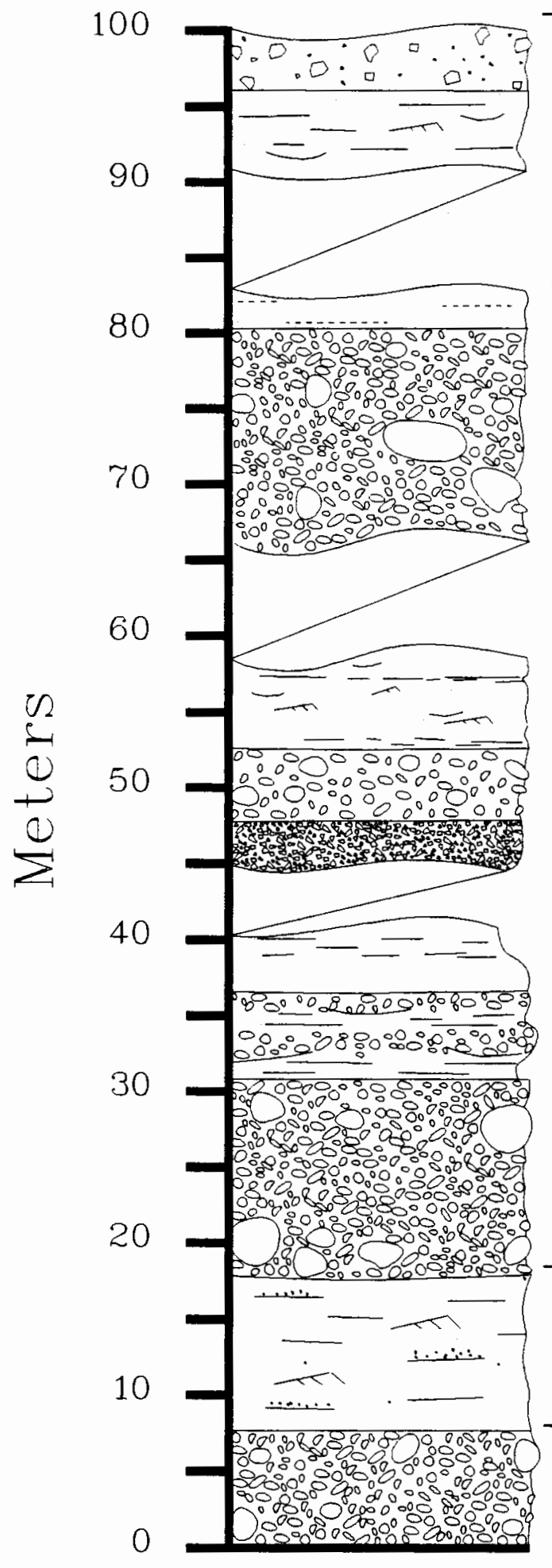

Tuff-breccia, pyroclastic flow, massive, poorly sorted, with angular clasts. Clasts: $40 \%$ vol., $2 \mathrm{~cm}-0.3 \mathrm{~m}$, avg. $5 \mathrm{~cm}$., $100 \%$ dacite. Matrix: $60 \%$ ash and pumice lapilli, $30 \%$ feldspar, $5 \%$ biotite, $5 \%$ homblende.

Volcanic sand, fine to coarse-grained, cross-bedded, poorly sorted, angular. Contains: $50 \%$ feldspar $(1-5 \mathrm{~mm}), 5 \%$ biotite ( $5 \mathrm{~mm}$ ), $5 \%$ hormblende $(1 \mathrm{~mm}), 30 \%$ white pumice lapilli (1-3 mm).

Volcanic sand, medium to coarse-grained, massive, poorly sorted, subangular to angular. Contains: $40-60 \%$ pumice lapilli $(2-5 \mathrm{~mm})$, with ash matrix.

Conglomerate, matrix supported, massive, poorly sorted, with rounded clasts. Clasts: $40 \%$ vol., $1 \mathrm{~cm}-1 \mathrm{~m}$, avg. $6 \mathrm{~cm}, 80 \%$ dacite, $20 \%$ basaltic. Matrix: fine to coarse-grained volcanic sand.

Volcanic sand, medium to coarse-grained, cross-bedded, poorly sorted, subangular. Contains: $20-40 \%$ white pumice lapilli (1-5 mm), 20-30\% feldspar, $15-20 \%$ homblende, $10-30 \%$ ash.

Conglomerate, matrix supported, massive, poorly sorted, with rounded clasts. Clasts: $40 \%$ vol., $1 \mathrm{~cm}-0.4 \mathrm{~m}$, avg. $7 \mathrm{~cm}, 100 \%$ dacite. Matrix: medium-grained sand.

Breccia, matrix supported, crudely bedded, poorly sorted, with angular clasts. Clasts: $60 \%$ vol., $5 \mathrm{~mm}-5 \mathrm{~cm}$, avg. $1 \mathrm{~cm}, 100 \%$ basaltic, with $1 \%$ basaltic cobbles $(2-5 \mathrm{~cm})$. Matrix: basaltic sand, poorly sorted, angular.

Volcanic sand, laminar bedded, poorly sorted, subangular to angular. Contains: $60 \%$ feldspar, $15 \%$ white pumice lapilli (1 mm-2 cm), 10\% homblende, $15 \%$ ash.

Interbedded conglomerate and sand. Conglomerate: clast supported, bedded, poorly sorted, rounded, $1.10 \mathrm{~cm}$, avg. $4 \mathrm{~cm}$, 60 dacite, $40 \%$ basaltic. Sand: volcanic, fine to medium-grained, laminar bedded, poorly sorted, angular. With $15 \%$ white pumice lapilli ( $1-5 \mathrm{~mm})$.

Conglomerate, clast supported, massive, poorly sorted, with rounded clasts. Clasts: $80 \%$ vol., $5 \mathrm{~cm}-1 \mathrm{~m}$, avg. $8-10 \mathrm{~cm}$. $70 \%$ dacite, $30 \%$ basaltic. Matrix: medium to coarse-grained volcanic sand.

Sand, fine to medium-grained, cross-bedded, subsorted, angular. Contains $70 \%$ feldspar, $20 \%$ homblende, $10 \%$ silt sized material. With $5 \mathrm{~cm}$ thick interbeds of white pumice lapilli $(1-2 \mathrm{~cm})$.

Conglomerate, clast supported, massive, poorly sorted, with rounded clasts. Clasts: $70 \%$ vol., $1 \mathrm{~cm}-0.5 \mathrm{~m}$, avg. $4 \mathrm{~cm}, 60 \%$ dacite, $40 \%$ basaltic. Matrix: medium-grained volcanic sand.

\section{Eigure 15 - Stratigraphic section "H" of the upper Ellensburg} Formation. 


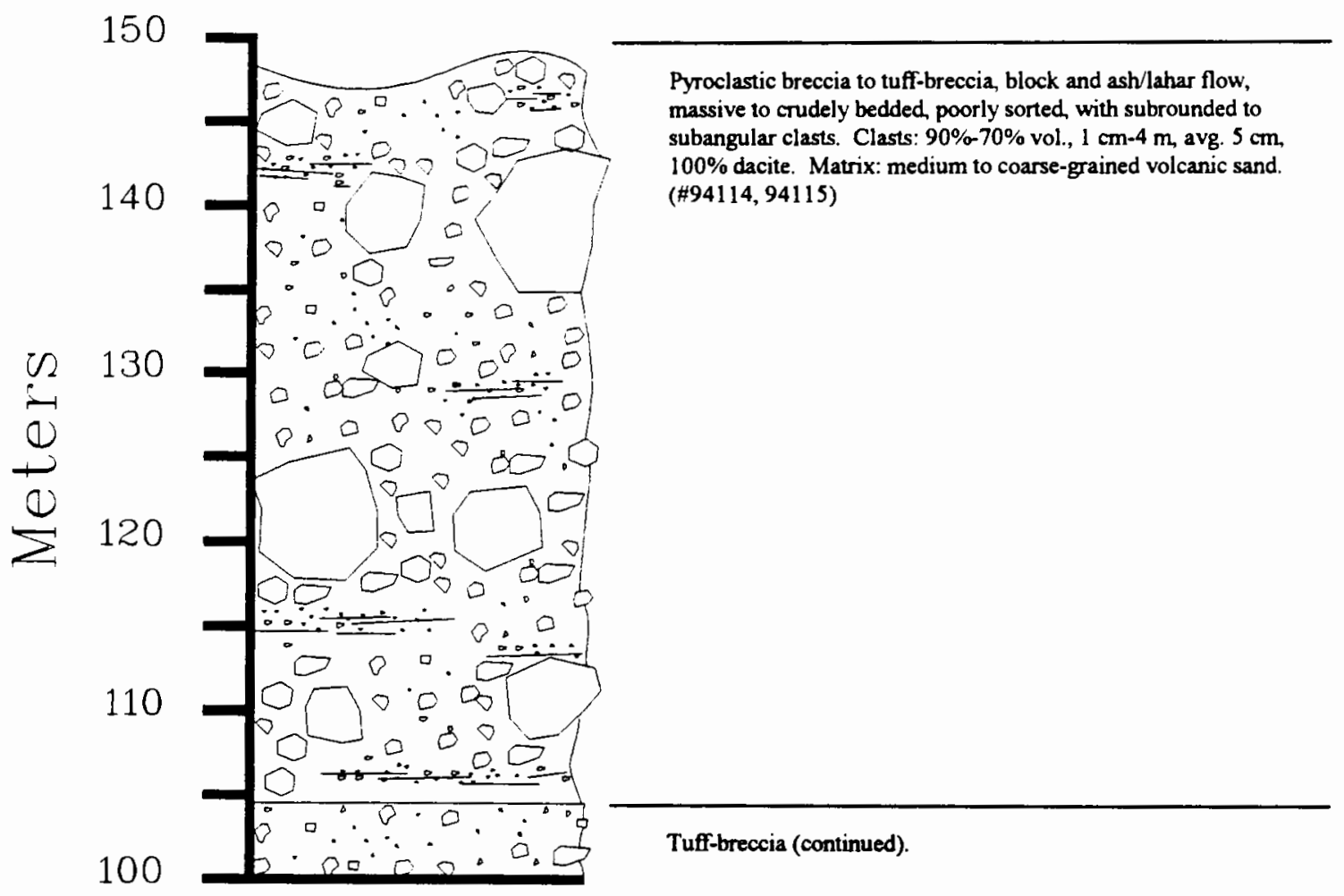

Figure 15 - Stratigraphic section "H" continued. 


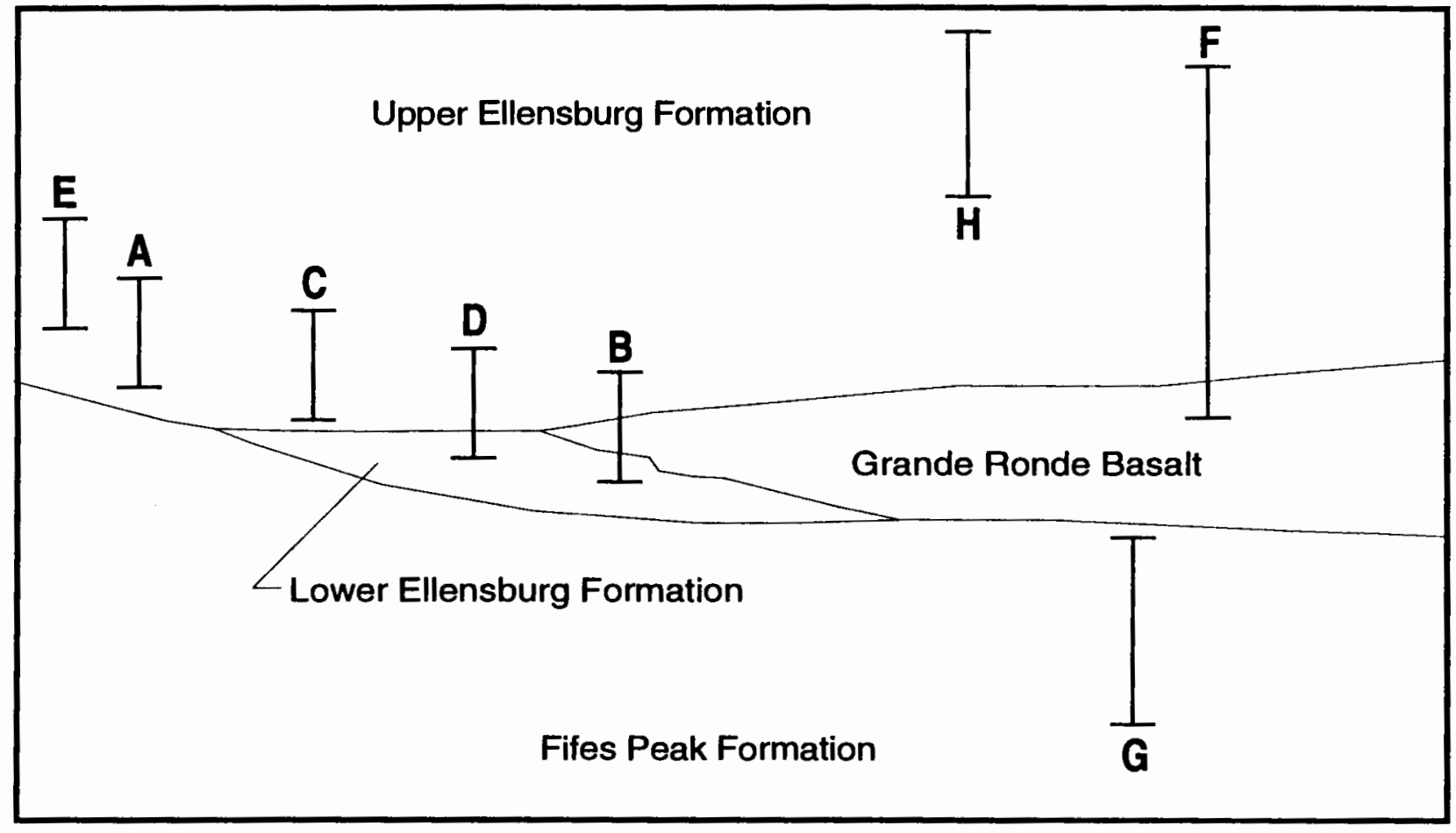

Figure 16 - Generalized stratigraphic positions of sections A through H (Figs. 8 through 15) in the Nile basin. Unit thicknesses and section lateral positions are generalized. 
sections with respect to the major units within the basin. Section G (Fig. 14) represents the Fifes Peaks Formation exposed along orr Creek (Fig. 7). All other sections (Figs. 8 through 13, and 15) are representative of the Ellensburg Formation.

Volcanic deposits, such as pyroclastic flows, pumice and ashfall deposits, and lahar deposits, are commonly overlain by massive conglomerates which are overlain by a series of finer grained, laminar bedded, volcanic sedimentary deposits. This sequence is commonly not complete and can be interrupted as the result of additional volcanic eruptions or erosional unconformities.

Contacts between the volcanic and sedimentary deposits are normally sharp. Where volcanic units overlie sedimentary units, sharp contacts are normally the result of sudden volcanic eruptions. Where sedimentary units overly volcanic units, sharp contacts are more commonly associated with an erosional unconformity. Gradational contacts have been observed between the more volcanic laminar bedded deposits and cross bedded volcanic conglomerates and sandstones. These gradational contacts probably represent reduction in the volcanic component of the sediment supply. However, there is more commonly an erosional unconformity between these two units. 
Facies Characteristics

As discussed in previous sections, the Ellensburg Formation consists of dacitic pyroclastic flow, pyroclastic fall, laharic, conglomerate, sandstone, and mudstone deposits, and at least one dacitic lava flow. Table 1 shows the percentage of exposed facies with respect to size categories (Compton, 1985). Percentages were estimated by summing the exposed thicknesses of each facies type and dividing by the total thickness of the exposed Ellensburg Formation in the basin.

VOLCANIC FACIES

Pyroclastic Flow Deposits

Pyroclastic flows are volcanically produced hot, gaseous, particulate density currents resulting from gravitational collapse of an erupting column (Fisher and Schmincke, 1984; Self, 1988). Pyroclastic flow deposits are typically poorly sorted and massive, with finer-grained, better sorted and possibly stratified basal ground surge and upper ash-flow deposits (Eisher and Schmincke, 1984; Cas and Wright, 1987). The denser, main body of the flow generally occupies valley lows where the basal surge and upper ash flow deposits can be found mantling higher areas. 
Table 1 - Thickness ( 8 ) of major facies types in the Nile basin.

\begin{tabular}{|c|c|c|}
\hline FACIES & 8 THICKNESS & EXPOSED \\
\hline \multicolumn{3}{|l|}{ Conglomerate: } \\
\hline Clast supported & 25 & \\
\hline Matrix supported & 6 & \\
\hline Pebble Gravel & 4 & \\
\hline \multicolumn{3}{|l|}{ Sandstone: } \\
\hline Volcanic & 17 & \\
\hline Non-volcanic & 2 & \\
\hline Mudstone: & 1 & \\
\hline \multicolumn{3}{|l|}{ Pyroclastic Breccia: } \\
\hline Lahar & 3 & \\
\hline \multicolumn{3}{|l|}{ Tuff-Breccia: } \\
\hline Pyroclastic Flow & 6 & \\
\hline Lahar & 16 & \\
\hline \multicolumn{3}{|l|}{ Lapilli-Tuff: } \\
\hline Pyroclastic Flow & 18 & \\
\hline Air Fall & 1 & \\
\hline Ash-Tuff: & 1 & \\
\hline TOTAL & 100 & \\
\hline
\end{tabular}


Approximately $23 \%$ of the deposits found within the study area are pyroclastic flows (Table. 1). Pyroclastic flow deposits are rarely found east, beyond the Nile basin (Smith and others, 1988), suggesting that the Nile basin is the most proximal of all the major basins. These deposits are light tan to gray, typically massive, matrix supported, poorly sorted, and form deposits of tuff breccia to lapilli tuff. Clasts occupy 10-608 of unit volume and are angular to subangular, ranging in size from $1 \mathrm{~cm}$ to $0.5 \mathrm{~m}$. Clasts are typically dacitic in composition and hornblende bearing, and vary in texture from sparsely vesicular to pumiceous. Some basaltic to basalticandesite accidental inclusions are present at the base of a flow. These inclusions are angular and $0.5-3 \mathrm{~cm}$ in size, and occupy less than 18 of unit.

Textural variability of dacitic clasts range from dense, to open-textured, to pumiceous. Open-textured dacitic clasts are typically most abundant, however the proportion of textural types is variable. Dense dacitic clasts compose $<5 \frac{8}{8}$ of clasts and probably represent xenoliths of vent walls or materials collected during flowage.

Vesicularity of pumice clasts is variable. The most vesicular pumice clasts are found within relatively thin-bedded units, ranging from 1 to $3 \mathrm{~m}$. Many moderately thick pyroclastic flows, between 5 and $15 \mathrm{~m}$ in thickness, contain denser clasts and have up to 608 open-textured dacitic clasts. White and 
yellow pumice clasts are commonly seen dispersed throughout the same deposits. Yellow pumice clasts may be the result of oxidization due to high $\mathrm{H}_{2} \mathrm{O}$ content.

Matrix is light tan, poorly sorted, subangular to subrounded, pumice lapilli and ash. Within a few units, the matrix is abundantly crystalline (Fig. 11, section D), containing mainly feldspar with lesser amounts of hornblende, biotite and accessory quartz. The more crystalline tuffs are found lower in section. At the base and top of many exposures lapilli and ash material are predominant and typically represent ground surge and ash-flow deposits. Lenses of pumiceous interbeds can be seen in otherwise massive flows. These lenses are called "pumice swarms" and are rarely continuous over long distances (Fisher and Schmincke, 1984).

Bed thicknesses range from only 1 or $2 \mathrm{~m}$ up to $40 \mathrm{~m}$ with the average ranging from 3 to $5 \mathrm{~m}$. Basal ground-surge deposits can be up to $5 \mathrm{~m}$ thick; however, most are only a few centimeters in thickness. Upper ash-flow deposits are typically a few meters thick and are commonly stratified. These upper ash-flow deposits are not always seen in section.

Pyroclastic Fall Deposits

Pyroclastic fall deposits are composed of fragments explosively ejected from a vent into the atmosphere and falling at varying distances from the source depending on the eruptive column conditions (Self, 1988). The deposits evenly mantle 
topographic features and form largely from eruptions of vesiculated high viscosity magmas (Cas and Wright, 1987). They are sorted to moderately sorted, and become progressively finer grained with distance from the source.

Pyroclastic fall deposits found within the study area consist of angular to rounded ash and pumice lapilli and are less than 38 of the total exposed deposits (Fig. 17). They are white to light tan, planar bedded, normally to reversely graded, and sorted to moderately sorted. Unit thicknesses range from 1 $\mathrm{cm}$ to $5 \mathrm{~m}$ with individual bedding thicknesses rarely greater than $5 \mathrm{~cm}$. Ripple and cross-bedding is common in reworked deposits. Where reworked ash material is interbedded with laminated mudstones, a lacustrine or slack water environment is suggested.

Pumice lapilli deposits are more common and are typically exposed in greater thicknesses than ash deposits. Pumice lapilli deposits are planar bedded, normal graded, poorly sorted to moderately sorted, with subangular to rounded fragments. They typically contain between 10-408 ash components. Laminar and cross-bedded reworked deposits are common and are typically interstratified with cross-bedded ash deposits and sand materials.

Accretionary lapilli were not found in the study area; however, accretionary lapilli occur in distal deposits of the Ellensburg Formation (Schmincke, 1964; Fisher and Schmincke, 
1984). Because the presence of accretionary lapilli increases with increasing distance from the volcanic source (Schumacher and Schmincke, 1990), the absence of such deposits was not unexpected within the proximal deposits of the Nile basin.

\section{Laharic Deposits}

The term "lahar" has been defined in many ways in the literature and has many meanings depending on the author. This author uses the term "lahar" in its general sense as a rapidly flowing mixture of rock debris and water originating on the flank of a volcano (Crandel1, 1971; Fisher and Schmincke, 1984; Brantley and Waitt, 1988; Rodolfo, 1989). Lahars are commonly formed in three ways: 1) transformation of watersaturated materials of mixed facies to lahars during emplacement, 2) slumping and flowing of water-saturated materials of a debris avalanche minutes to hours after emplacement, or 3) breakout of debris-avalanche-dammed lakes hours to years after its emplacement (Siebert and others, 1989; Glicken, 1991).

Lahars follow pre-existing valleys and are commonly interstratified with fluvial sands and gravels (Fisher and Schmincke, 1984; Cameron and Pringle, 1986). Those in the Ellensburg Formation are no exception and contain monolithic or heterolithic accumulations of dense angular to subangular 
rock components mixed with ash-sized mineral and daciticlithic particles.

Approximately 198 of exposed strata in the Nile basin are laharic. These deposits range in thickness from a few meters to over $40 \mathrm{~m}$, and form volcanic breccia and tuff-breccia deposits (Table 1). They are light tan to gray, massive, poorly sorted, and contain angular to subangular fragments. Clast size ranges from $1 \mathrm{~cm}$ to $4 \mathrm{~m}$ and occupies a total volume of $40-908$ of the units. Crude normal grading of the clasts occurs in a few units.

Clasts are typically open-textured to dense, porphyritic hornblende dacites; however, up to 408 basaltic to basalticandesite clasts occur in lahar deposits stratigraphically lower in section. These clasts are angular to subangular, and between $1 \mathrm{~cm}$ and $1 \mathrm{~m}$ in size. A few accidental basaltic and dacitic cobbles are present and may have been incorporated into the lahars as they flowed down valley. The lower Ellensburg Formation contains several laharic deposits which consist chiefly of basaltic clasts (Fig. 18). However, their matrix consists of tan colored pumice and ash which is commonly produced in andesitic or dacitic eruptions.

Matrix is light tan to gray, poorly sorted, angular fragments, medium- to coarse-grained, volcanic sandstone, pumice lapilli, and ash materials. Matrix percentage is generally higher at the top and commonly at the base of the deposits. The 


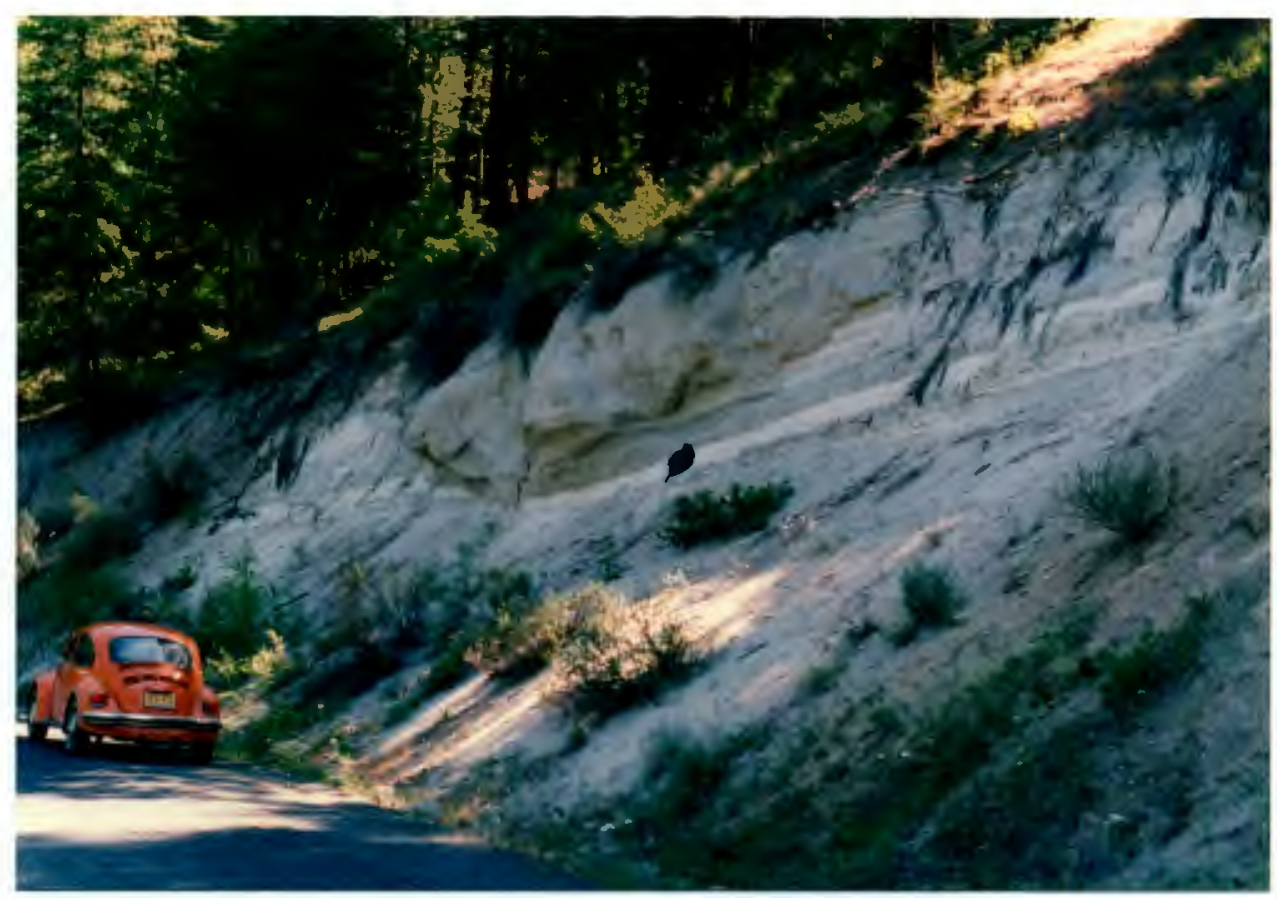

Figure 17 - Interbedded pumiceous sedimentary and volcanic air-fall deposits. Dark colored backpack is on air-fall ash deposits. Above backpack is a trough-bedded pumiceous volcanic sandstone. Exposure along NF collector road \#1600.

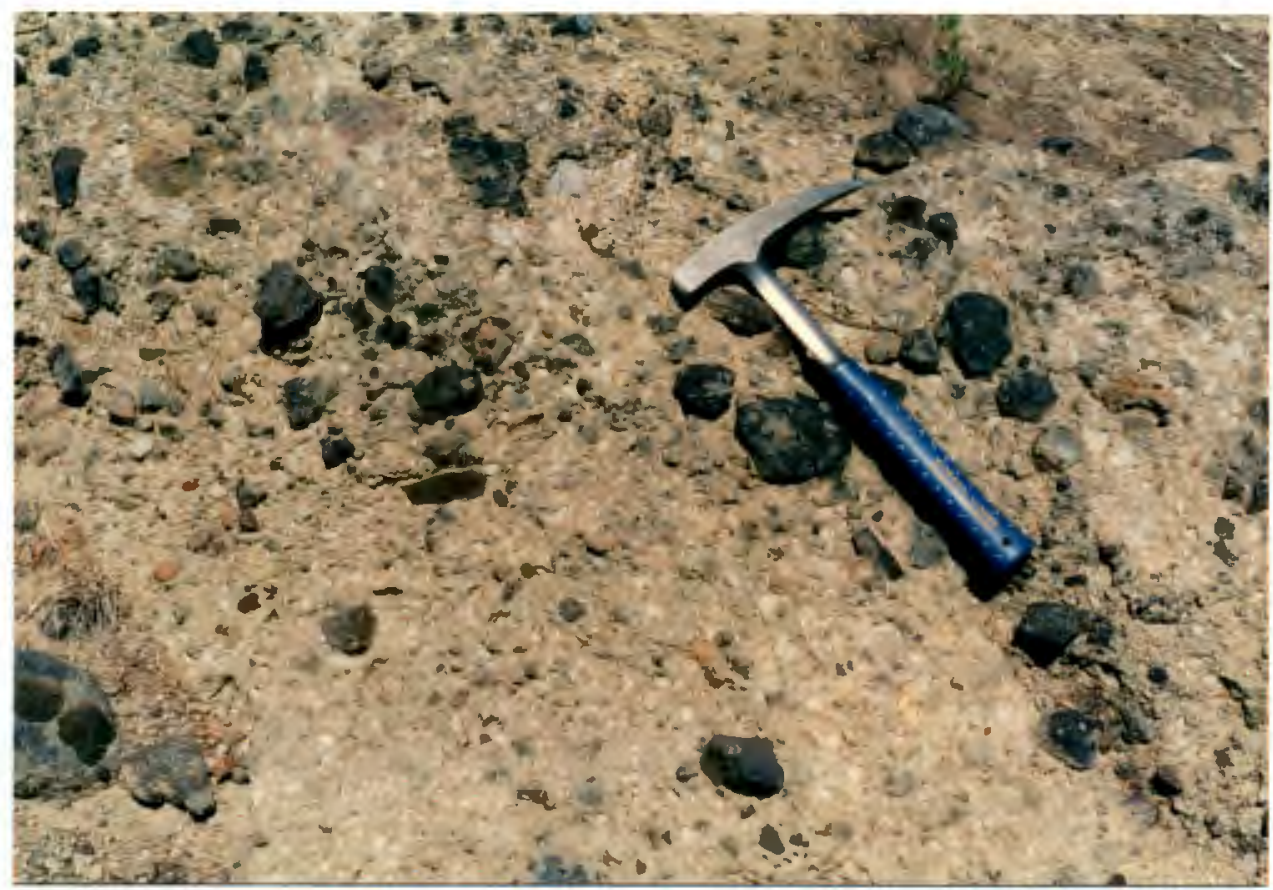

Figure 18 - Basaltic laharic deposit of the lower Ellensburg Formation. Contains dark-colored lithic clasts, white and gray pumice in a tan lapilli tuff matrix. Exposure along NF road 1920 road along Fifes Ridge, north of American River. 
tops of the lahar units tend to be finer grained and somewhat laminar bedded due to the setting out of the larger fragments and the resulting increase in the total water content allowing for laminar flow. The basal layer, in a few units, also tends to be finer grained and laminar bedded. This is due to a high shear stress at the base of the lahar, allowing the basal part to move in a laminar flow fashion. This laminar flow allows the lahar to carry a large mass with relatively little deformation of the material and little erosion at the base of the unit (Fisher and Schmincke, 1984; Brantley and Waitt, 1988). Several lahar units contain randomly oriented tree casts (Fig. 13, section F). Sizes range from $3 \mathrm{~cm}$ to $20 \mathrm{~cm}$ in diameter and commonly extend into the outcrop for $20 \mathrm{~cm}$ to $50 \mathrm{~cm}$. These casts are typically sediment filled and contain no charred wood fragments, as previously noted by Schmincke (1967a). Dark brown discolorations around the rims of the woody fragments indicate oxidation of rock material as the result of the organic biodegradation of the wood.

Prismatically jointed clasts within many of the laharic deposits indicate in situ cooling from high temperatures (Smith, 1988a). Jointed clasts range in size from 0.5 to $2 \mathrm{~m}$ and are most commonly seen in the center portions of the larger lahar deposits (greater than $20 \mathrm{~m}$ thick). Jointing patterns occur only in dense dacite. This is possibly due to the greater heat retention of the denser clasts. 
The thickest and most extensive lahar unit is found at the top of section $H$ (Fig. 15). Finer grained interbeds within the main unit possibly represent several laharic events in a single eruptive event. At the top of the units, the deposits become massive and unsorted, with clasts up to $4 \mathrm{~m}$ in size and a clast volume of 908 (Fig. 19). Depositional characteristics are similar to that of debris avalanche or block-and-ash flow deposits (Fig. 20).

Lava flows

One dacitic lava flow was found within the field area and occurs in the upper Ellensburg Formation. The outcrop is approximately $20 \mathrm{~m}$ long and $4 \mathrm{~m}$ high and is exposed along National Forest Road 645, located in the NE-4, Sec. 1, T. 15 N., R. 14 E., Meeks Table $7 \frac{1}{2} \mathrm{~min}$. Quadrangle. The lava flow is blocky jointed and partly fragmented (Fig. 21) and is possibly an autobrecciated flow front. The flow consists of a gray, porphyritic dacite with approximately 2 o xenoliths of white to light tan porphyritic, open-textured dacite, $0.2-2.0$ $\mathrm{cm}$ in diameter. Phenocrysts consist of plagioclase and hornblende and range in size from 0.5 to $2 \mathrm{~mm}$ long, and occupy approximately 50 of of the rock by volume. 


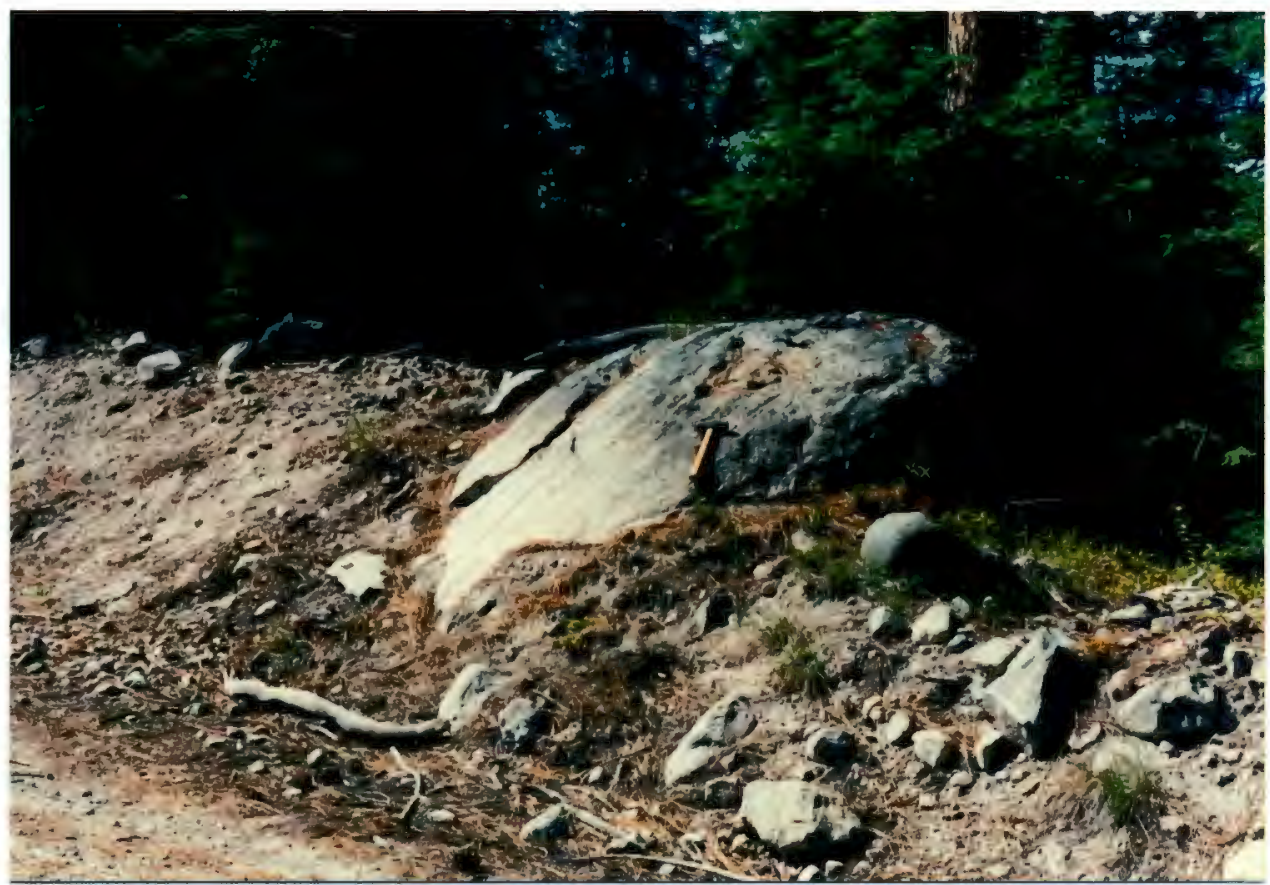

Figure 19 - Large dacitic boulder in debris avalanche deposit exposed along NF local road \#233.

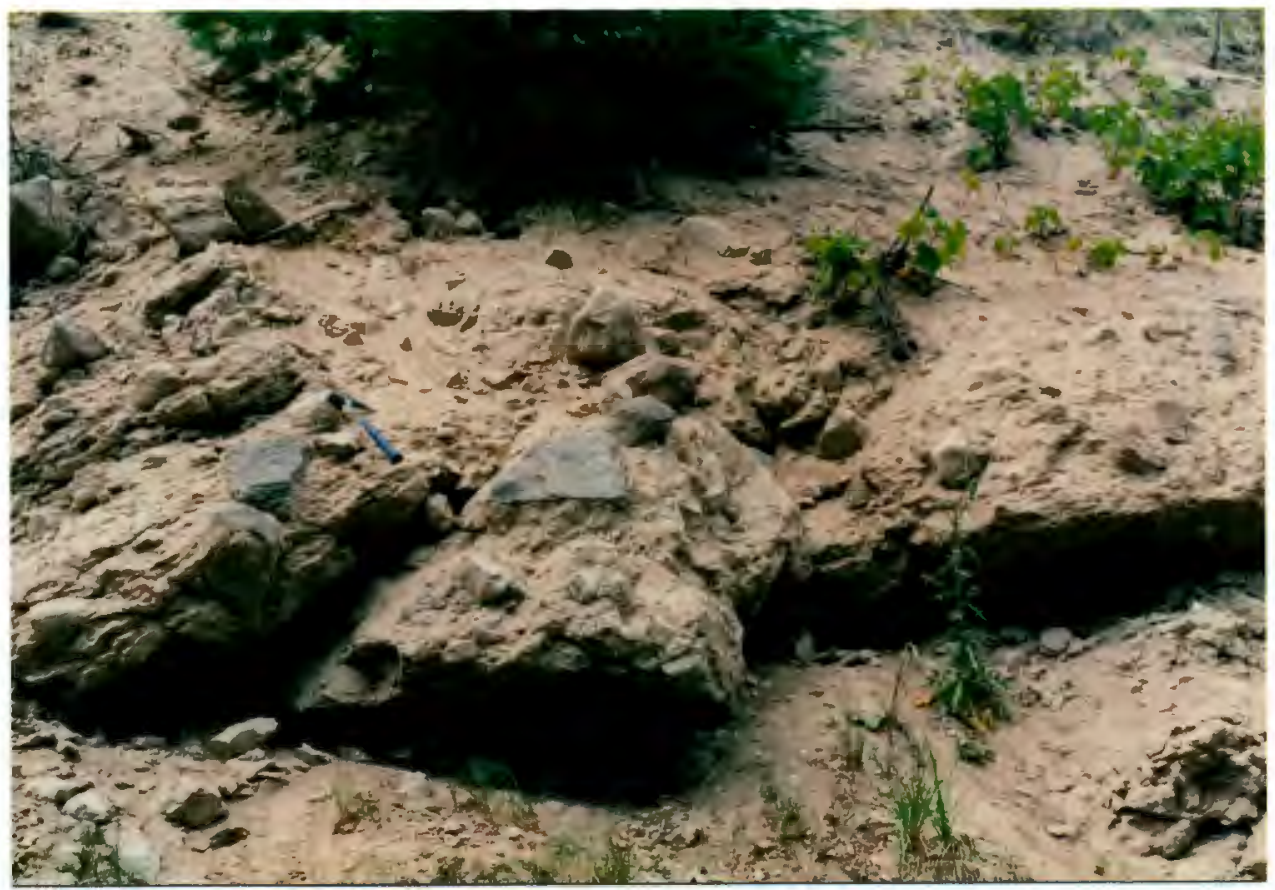

Figure 20 - Debris avalanche deposits exposed along NF local road \#233. 
FLUVIAL FACIES

In a youthful volcanic system fluvial deposits make up only a small percentage of the total deposits. However, over time ( 20 to 30 years) braided fluvial systems become a major component of the facies record (Cas and Wright, 1987; Fisher and Smith, 1991). Resulting fluvial deposits give information on the proximal to distal nature of the deposits.

Conglomerates

Conglomerates and pebble gravels compose 318 of the deposits of the Ellensburg Formation and represent the largest depositional component in the Nile basin (Table 1). They are massive to crudely bedded, poorly sorted, and rounded, and range from clast supported to matrix supported (Figs. 22). Clasts range in size from boulders to pebbles $(1 \mathrm{~cm}-3 \mathrm{~m}$ ) and consist of porphyritic dacite, and basalt to basalticandesite. Typically, conglomerates found lower in section in the upper Ellensburg Formation show a higher percentage of basaltic and basaltic-andesite clasts, which can be up to 80 to 908 . Higher in section the dacite clasts occupy up to 1008 of clast volume. Conglomerate found in the lower Ellensburg Formation commonly contain 1008 basaltic clasts. However, conglomerates with abundant volcanic matrix, contain a high dacitic clast content. 


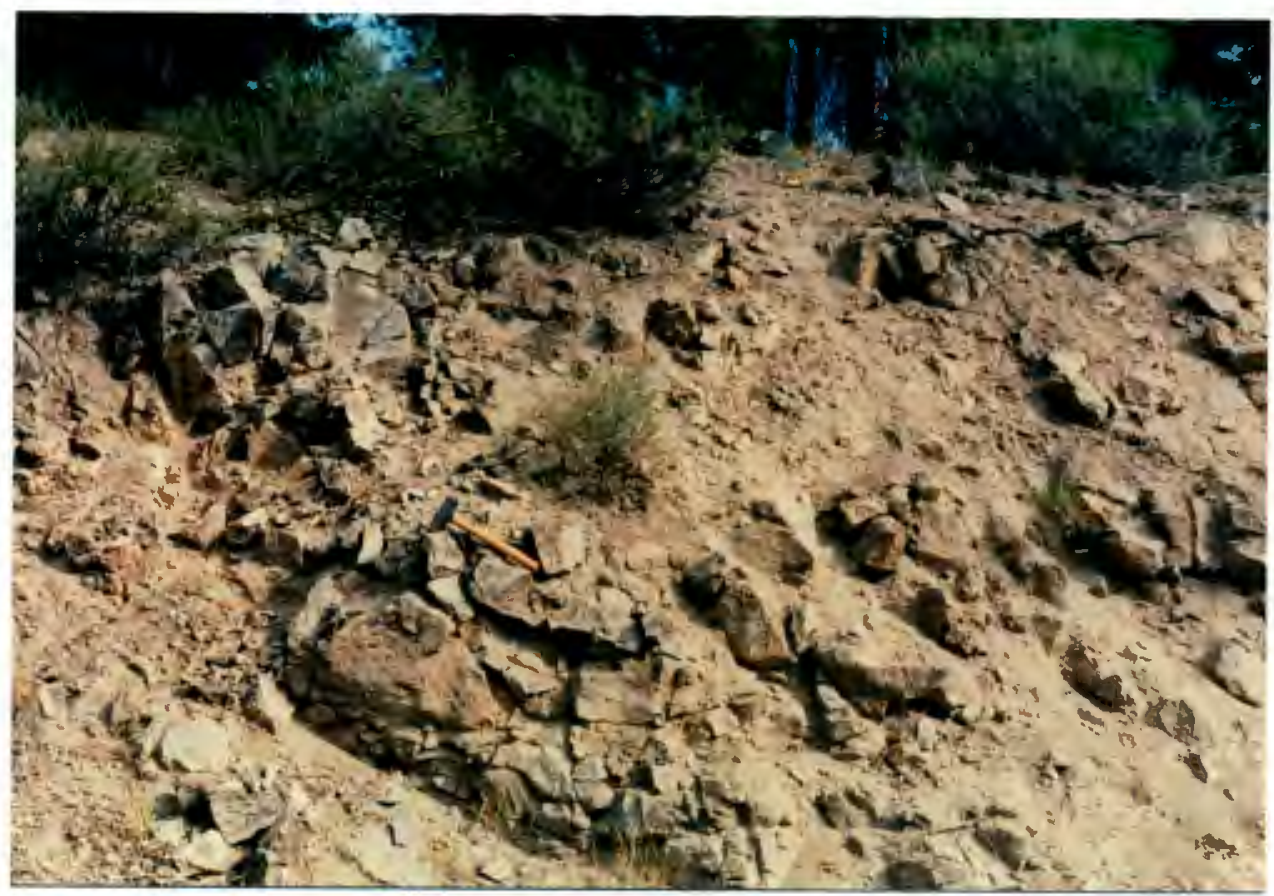

Figure 21 - Dacitic lava flow approximately $14 \mathrm{~km}$ east of old Scab Mountain exposed along NF local road \#16.01.

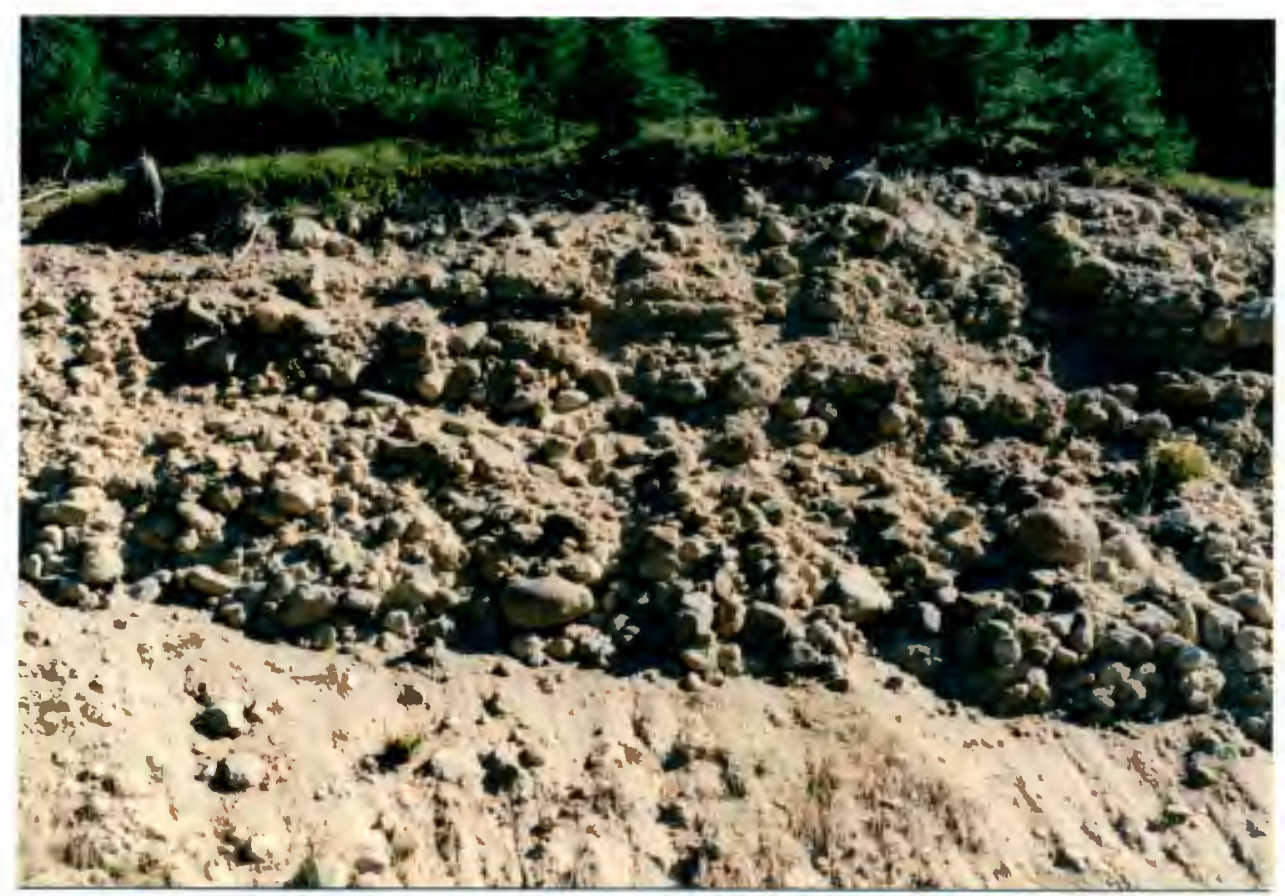

Figure 22 - Clast supported dacitic conglomerate exposed along NF local road \#236, immediately north of orr creek. 
Matrix is medium- to coarse-grained, poorly sorted, angular to subround, volcanic sandstone. Sandstone matrix varies in lithology from abundant pumiceous to crystal particles. Grains consist of dacitic to basaltic particles, ash, lapilli, and crystals of plagioclase, hornblende, biotite, and hypersthene.

Bedding ranges from massive to lenticular cut and fill. Conglomerates are commonly interstratified with cross-bedded sandstones and less commonly interstratified with planar bedded to cross-bedded reworked ash and pumice. Clast supported conglomerates are massive and poorly sorted, with bed thicknesses ranging from $1 \mathrm{~m}$ to $30 \mathrm{~m}$. Matrix supported conglomerates are in massive to lenticular trough cross-bedded deposits, and interstratified with volcanic sandstones and pebble gravels. Gradations from bedded conglomerates to cutand-fill trough bedded sandstones suggest that the conglomerates were the products of braided channels or sheetflood deposits (Smith, 1988a). Massive conglomerates suggest a higher energy fluvial environment.

\section{Sandstones}

Sandstones comprise about 198 of the exposed deposits in the study area. They are typically pale tan to light brown, trough to planar cross-bedded, and poorly sorted, with angular to subround fragments. They range from fine- to predominantly 
medium- to coarse-grained. Channel scour lag gravels are common, with some units containing 5 to 408 pebble sized material. Sand size grains are composed of dacitic to basaltic particles, pumice lapilli, and crystals of plagioclase, hornblende, biotite, hypersthene, and iron oxides. Most sandstone deposits contain 5 to 25 ash-silt matrix. Sandstone is commonly interstratifed with fluvial pumice lapilli deposits. Interstratified, lenticular deposits of clast to matrix supported conglomerates and pebble gravels are also common.

Planar-bedded sandstone deposits are generally, normal graded, medium- to coarse-grained, moderately sorted, and angular, with bed thicknesses from $0.5-5 \mathrm{~cm}$. These deposits are characteristic of coarse-grained lacustrine deposits which are normally found in shallow lakes marginal to floodplains.

Mudstone

Mudstone deposits comprise less than 18 of exposed units in the study area. These deposits are generally dark brown, planar bedded and commonly interbedded with fine- to mediumgrained sandstone. Approximately 5 to $15 \%$ of mudstone deposits consist of fine- to coarse-grained lithic or crystal grains. Bed thicknesses ranges from 0.1 to $3 \mathrm{~cm}$. Planar bedded mudstone deposits are characteristic of overbank and lacustrine environments. 
DACITIC INTRUSIONS

Miocene dacitic intrusive bodies are common in the Washington Cascade Range. Within the Naches River-Bumping Lake area several porphyritic dacitic intrusive bodies have been identified and may have been associated with volcanic centers which contributed materials to the Ellensburg Formation in the Nile basin. One of the largest of these dacitic intrusive bodies is old Scab Mountain, which is located just west of the Nile basin along the Bumping River (Fig. 2).

Immediately south of old Scab Mountain, at the northern end of Nelson Ridge, lies another large dacitic body, informally called the dacite of Barton Creek (personal communication, P. E. Hammond, 1996). K-Ar age determination of this body has been obtained by smith (1989) and reveals an age of $4.69 \pm 0.17 \mathrm{Ma}$. This age is much younger than any known Ellensburg deposits found in the Nile basin. If volcaniclastic deposits were derived from this possible center, they may have been removed by erosion.

Several other dacitic bodies are exposed along the American River and near the head waters of the Little Naches River. Although no age determinations have been obtained from these possible centers, several samples were collected for chemical analysis during this investigation. 
old Scab Mountain

Old Scab Mountains lies at the western edge of the Nile basin (Fig. 2, Plate 1). It consists entirely of biotitehornblende dacite which intrudes oligocene and Miocene stratigraphic units. It extends from 950 to $2,014 \mathrm{~m}$ above sea level, and covers an area of approximately $7.07 \mathrm{~km}^{2}$.

Topographically, old Scab Mountain forms a rounded or "dome" shaped hill with an inactive glacial cirque on its north facing side (Figs. 23 and 24). Its northwestern side forms its longest slope, descending from its top to the eastern bank of the Bumping River at a slope of about 30 to $35^{\circ}$. Along its eastern face, easterly dipping Oligocene and Miocene units represented by the Fifes Peak Formation and the Grande Ronde Basalt, respectively, are exposed at a high elevation due to folding and limit topographic expression.

The dacite at old Scab Mountain is light gray to greenishgray, porphyritic, and holocrystalline. Phenocrysts consist primarily of plagioclase with lesser amounts of hornblende, biotite and quartz, and occupy approximately 30 to 408 of the total rock volume (see Petrography section for point count totals). Phenocrysts range from $3 \mathrm{~mm}$ to $<1 \mathrm{~mm}$ in size and are euhedral to subhedral; quartz phenocrysts being anhedral. Groundmass is fine-grained and consists mainly of plagioclase. Greenish tints are primarily the result of alteration of 


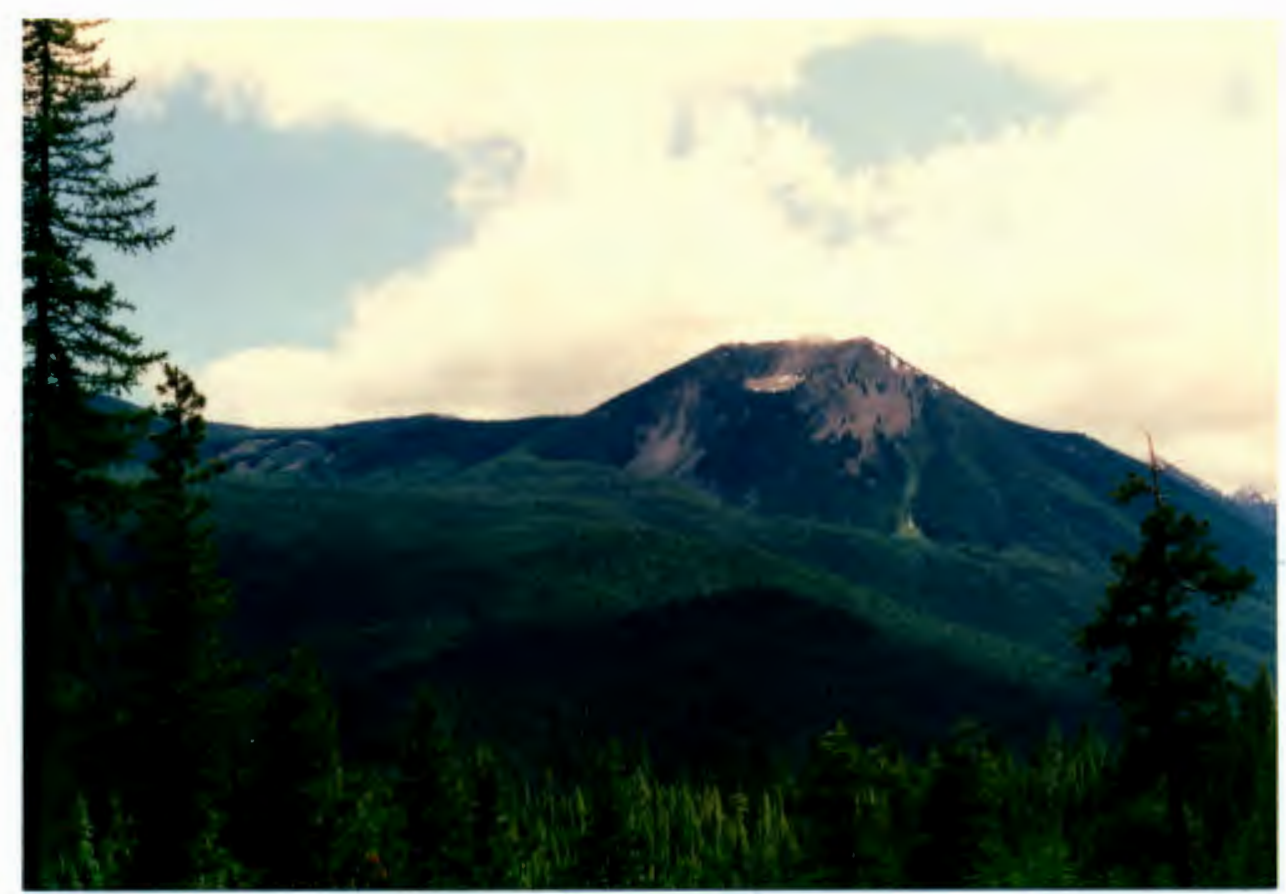

Eigure 23 - Looking south towards Old Scab Mountain from NF local road \#635.

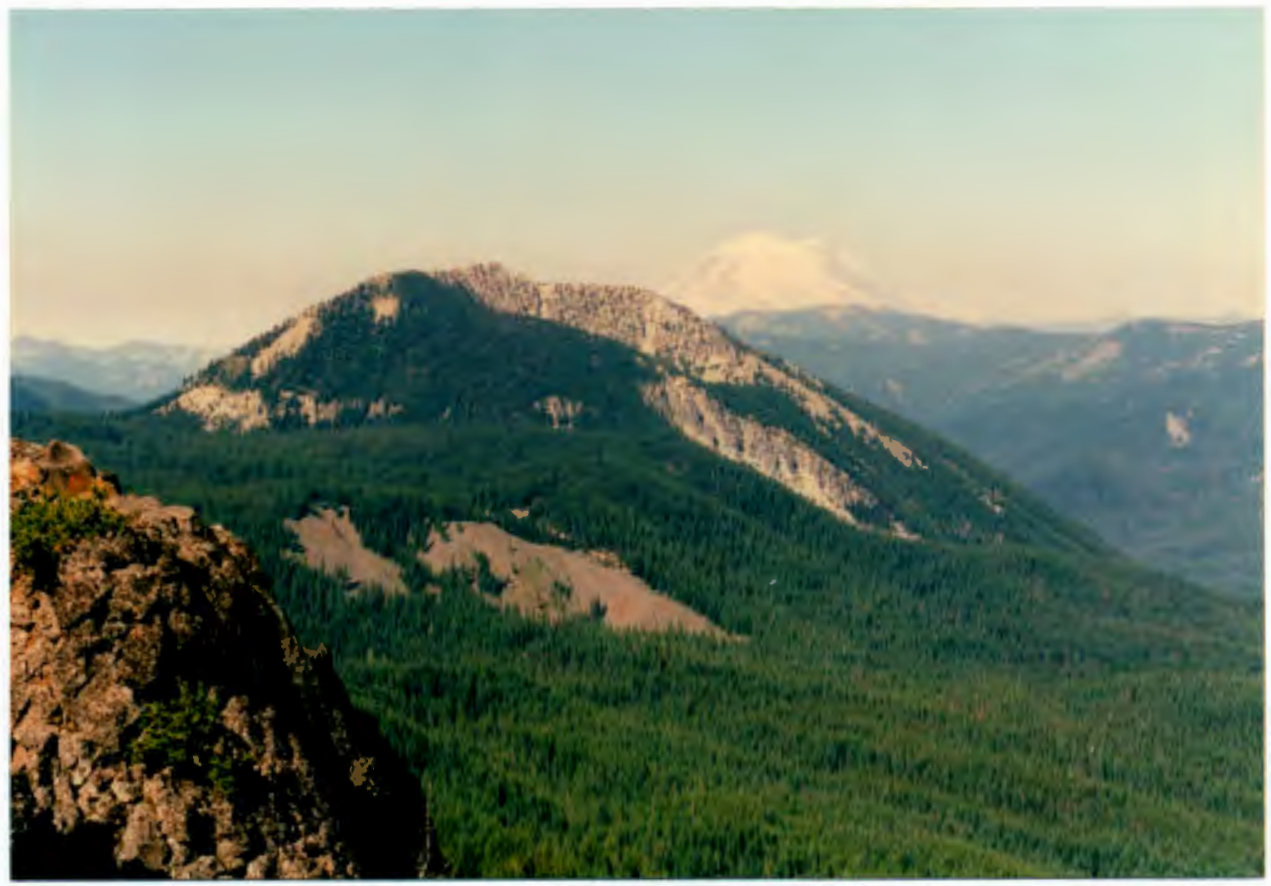

Figure 24 - Looking west towards old Scab Mountain from Little Bald Mountain. 
hornblende, biotite and minor volcanic glass to chlorite as a consequence of interaction with late-stage hydrothermal fluids. Alteration of volcanic glass to secondary clay minerals has also occurred. Texture is massive with no indication of zoning or alignment of crystal laths.

Geologic mapping reveals that old Scab Mountain is essentially a single intrusive body. No dikes, sill, or radial intrusion have been identified within the main body of old Scab Mountain. Mineralogic zoning within the body is also not present.

Internal fracturing is conchoidal to columnar (Figs. 25 and 26). Tabular fractures perpendicular to the slope are present throughout the exposed surfaces of the intrusion and give a false sense of internal bedding or layering. They are probably formed by tension fracturing during exhumation of the intrusion during erosion.

Its outcrop, homogeneous nature, and shallow emplacement suggests that the intrusion is the plug or shallow magma body of an eroded volcanic center. No laminar texture or vesiculation is evident which would indicate upward flowing of the original magma within a conduit. The exposed intrusion probably represents a shallow magma chamber of the original center, and not an infilled vent or conduit. 


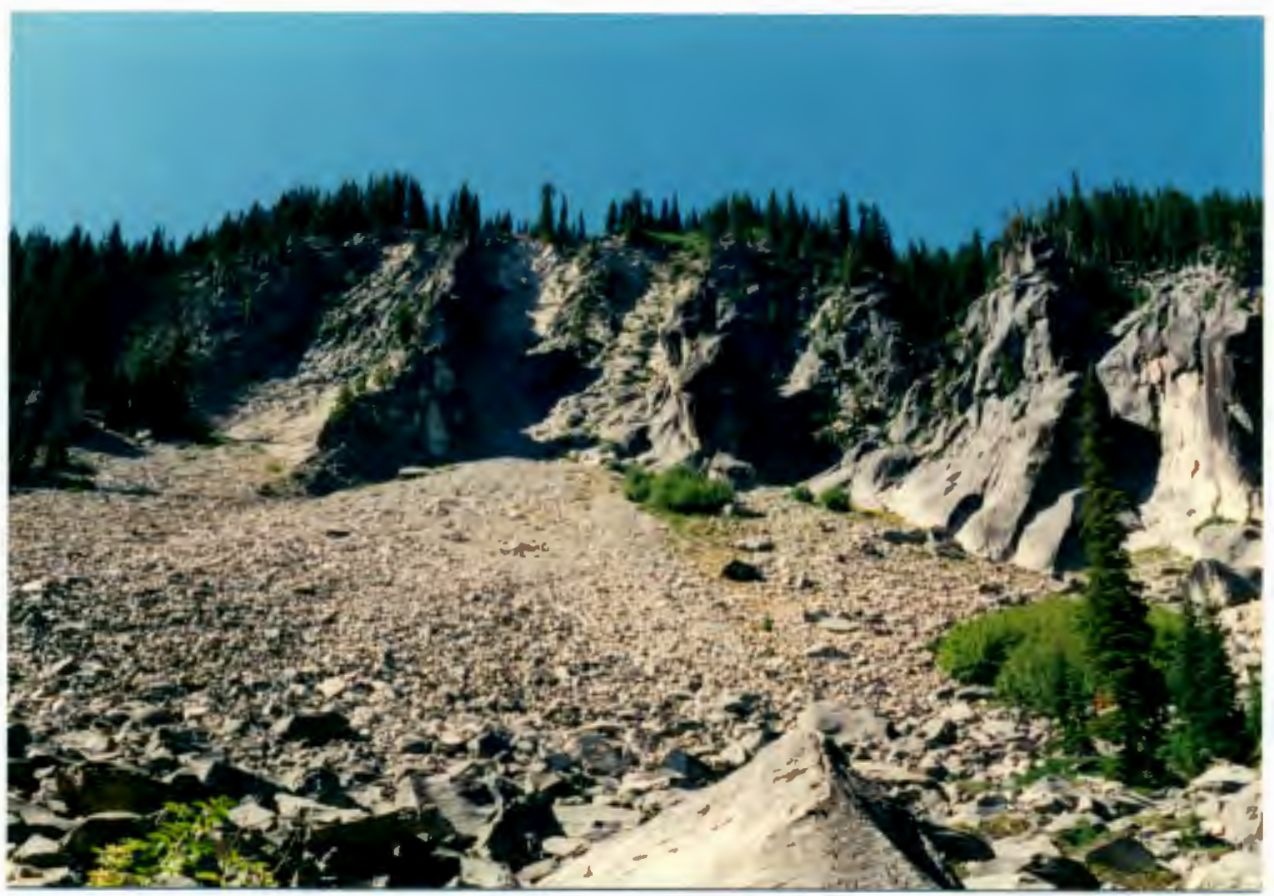

Figure 25 - Cliff slope exposure on north side of old Scab Mountain. Upper slope exposing conchoidal jointing patterns. 


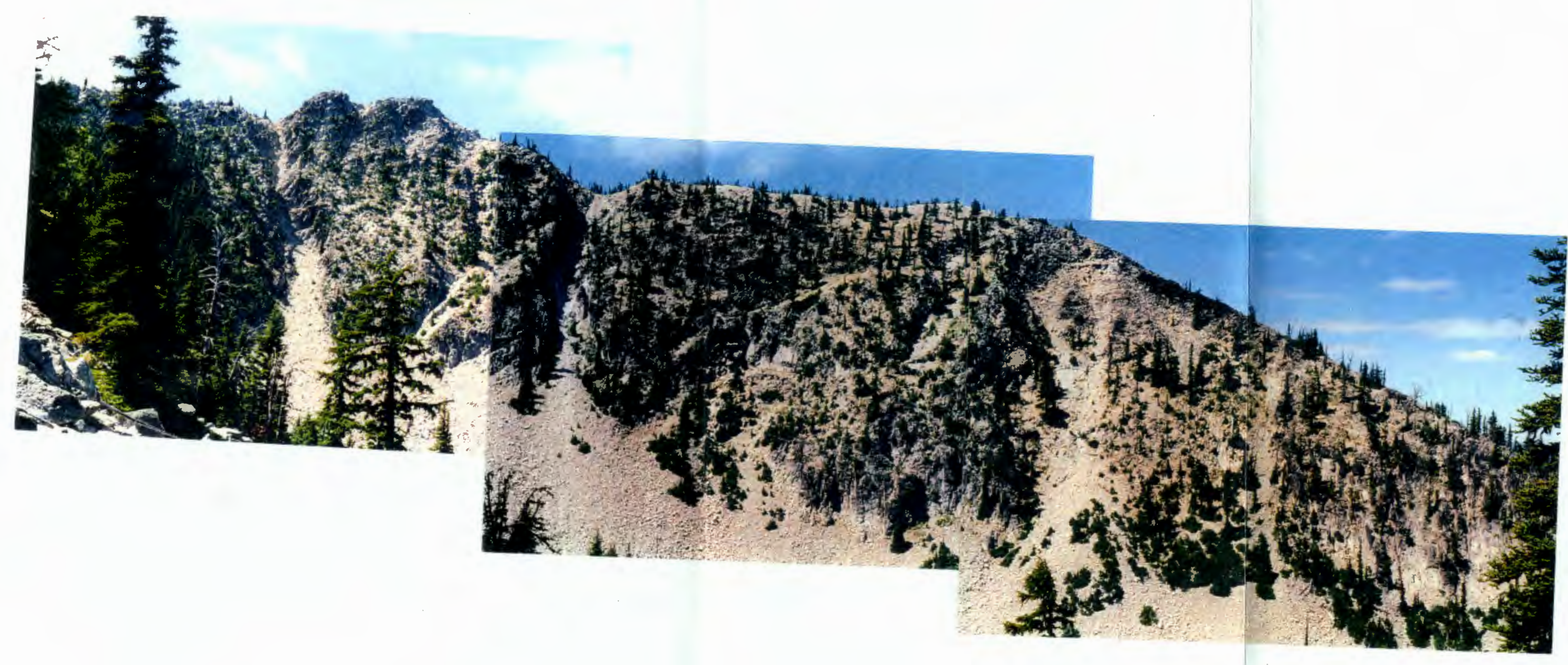


Several landslides occur along the slopes of old Scab Mountain. These slides are generally shallow in depth and consist primarily of rock slides. The largest landslide occurs at the northeast slope of the mountain. This slide was probably originally the remnant of a glacial cirque which subsequently destabilized the upper slope resulting in rock fall and sliding. Most of the rock slides have been the result of the tension fractures formed perpendicular to the slope face. Initial translational movement, initiated by possible freeze and thaw activity, results in breakup of the rock mass and subsequent rock sliding. Eew trees or other plant types grow along the upper slopes of Old Scab Mountain as a direct result of the sliding activity.

Immediately west of old scab Mountain, a biotite dacitic porphyry sill is exposed along the western bank of Bumping River, and strikes in a northwest direction towards American Ridge. The sill has been sampled and K-Ar dated by Smith (1989) at $8.79 \pm 0.20 \mathrm{Ma}$. This determination is within the range obtained for the Ellensburg Formation overlying the Grande Ronde Basalt in the Nile basin. The contact between the sill and old Scab Mountain has been eroded and covered by alluvium. However, geologic mapping and lithologic similarities between hand samples of old Scab Mountain and the sill indicates that the two are possibly associated with a common magma source and possibly have a common age of emplacement. 


\section{PETROGRAPHY}

Compositional classification of all volcanic rocks in the map area is based on the total alkali-silica (TAS) diagram (Fig. 39). The chemistry of rock units is discussed further in the geochemistry section. Petrographic descriptions here are based on study of hand specimens and thin sections with aid of a polarizing microscope.

\section{OLD SCAB MOUNTAIN}

Dacitic rocks from old scab Mountain are pale tan, medium- to fine-grained, holocrystalline and porphyritic with phenocrysts of plagioclase, pyroxene, quartz, hornblende, biotite and magnetite (Table 2) (Fig. 27). Phenocrysts occupy 30 to 358 of rock volume and consist primarily of plagioclase. Matrix is crystalline and consists of primarily plagioclase with lesser amounts of orthopyroxenes (possibly hypersthene) and magnetite. On the whole the rocks show a panidiomorphic texture; however, all the quartz phenocrysts and 30 to 408 of the plagioclase groundmass are anhedral. Flow textures are absent and there is no indication of alignment of crystals or layering. 
Table 2 - Modal analyses of thin sections.

Unit

Dacite of Old Scab Mountain

\begin{tabular}{|c|c|c|c|c|c|c|c|}
\hline Sample & $\begin{array}{c}\mathrm{CCH} \\
94019\end{array}$ & $\begin{array}{c}\mathrm{CCH} \\
94020\end{array}$ & $\begin{array}{c}\mathrm{CCH} \\
94079\end{array}$ & $\begin{array}{c}\mathrm{CCH} \\
94080\end{array}$ & $\begin{array}{c}\mathrm{CCH} \\
94081\end{array}$ & Mean & SD \\
\hline Plagioclase (ph) & 24.9 & 31.7 & 30.1 & 30.5 & 27.2 & 28.88 & 2.77 \\
\hline Plagioclase (mic) & 49.7 & 50.4 & 50.9 & 52.6 & 58.0 & 52.32 & 3.35 \\
\hline Quartz (ph) & 6.0 & 2.2 & 0.4 & 2.8 & 0.7 & 2.42 & 2.24 \\
\hline Hornblende (ph) & 1.9 & 1.2 & 0.1 & 0.2 & 0.2 & 0.72 & 0.80 \\
\hline Biotite (ph) & 0.9 & 0.2 & 0.4 & 0.3 & 0.6 & 0.48 & 0.28 \\
\hline Orthopyroxene (ph) & 0.3 & 0.1 & 0.2 & 0.3 & 0.4 & 0.26 & 0.11 \\
\hline Orthopyroxene (mic) & 3.1 & 0.7 & 11.9 & 9.7 & 8.0 & 6.68 & 4.66 \\
\hline Clinopyroxene (ph) & 0.2 & - & ---- & -- & -- & 0.04 & 0.09 \\
\hline Magnetite (ph) & 0.9 & 0.8 & 1.2 & 0.8 & 0.8 & 0.90 & 0.17 \\
\hline Magnetite (mic) & 4.3 & 0.5 & 4.8 & 2.8 & 4.1 & 3.30 & 1.73 \\
\hline Epidote & $-\cdots--$ & trace & $-\cdots-$ & ---- & ---- & $-\cdots-$ & ---- \\
\hline Groundmass & $-\ldots$ & ---- & $-\ldots$ & $-\cdots-$ & ---- & $-\ldots$ & ---- \\
\hline Chlorite & 7.8 & 12.1 & ---- & --- & $---\ldots$ & 3.98 & 5.66 \\
\hline Xenoliths & ---- & $-\cdots$ & ---- & --- & $-\cdots-$ & ---- & $-\cdots$ \\
\hline Voids & ---- & ---- & ---- & $\ldots-\ldots$ & $-\ldots-$ & ---- & $\ldots-\ldots$ \\
\hline
\end{tabular}

$(\mathrm{ph})=$ Phenocrysts

$($ mic $)=$ Microlites 
Table 2 - Continued.

Unit Ellensburg Formation (Tuff Clasts)

\begin{tabular}{|c|c|c|c|c|c|c|c|c|c|}
\hline \multirow[t]{2}{*}{ Sample } & $\mathrm{CCH}$ & $\mathrm{CCH}$ & $\mathrm{CCH}$ & $\mathrm{CCH}$ & $\mathrm{CCH}$ & $\mathrm{CCH}$ & $\mathrm{CCH}$ & & \\
\hline & 94010 & 94028 & 94056 & 94060 & 94092 & 94118 & 94120 & Mean & SD \\
\hline Plagioclase (ph) & 11.8 & 11.1 & 14.5 & 31.7 & 33.8 & 32.2 & 16.7 & 21.69 & 10.36 \\
\hline Plagioclase (mic) & 36.0 & 24.3 & 34.2 & 24.6 & 31.6 & 56.2 & 33.4 & 34.33 & 10.68 \\
\hline Quartz (ph) & 0.4 & 0.2 & 0.6 & 0.1 & ---- & $-\cdots-$ & 0.7 & 0.29 & 0.29 \\
\hline Hornblende $(\mathrm{ph})$ & 1.3 & 6.1 & 3.9 & 4.9 & 5.2 & 6.3 & 3.3 & 4.43 & 1.75 \\
\hline Biotite (ph) & 0.4 & 0.4 & 0.9 & 0.4 & 1.4 & 0.7 & 0.9 & 0.73 & 0.37 \\
\hline Orthopyroxene (ph) & 0.1 & trace & ----- & 0.9 & 0.5 & ---- & ---- & 0.25 & 0.37 \\
\hline Orthopyroxene (mic) & 1.1 & 0.5 & 0.6 & 2.1 & ---- & 1.1 & 0.2 & 0.80 & 0.71 \\
\hline Clinopyroxene (ph) & $-\cdots---$ & ----- & ----- & trace & 0.2 & ---- & 0.1 & 0.04 & 0.08 \\
\hline Magnetite (ph) & 0.5 & 0.4 & 1.2 & 1.0 & 1.2 & 1.1 & 2.3 & 1.10 & 0.62 \\
\hline Magnetite (mic) & 2.1 & 1.8 & 0.7 & 2.4 & 1.3 & 2.4 & 1.3 & 1.71 & 0.64 \\
\hline Epidote & ----- & ----- & ---- & ---- & ---- & ---- & ----- & $-\cdots--$ & $-\cdots$ \\
\hline Groundmass & 46.3 & 55.2 & 43.4 & 32.7 & 24.8 & ----- & 41.1 & 34.79 & 18.15 \\
\hline Chlorite & ----- & ----- & ---- & $-\cdots-$ & ---- & ---- & ----- & ----- & ----- \\
\hline Xenoliths & $---\cdots$ & 6.6 & 12.9 & $---\cdots$ & $----\cdots$ & ----- & 15.5 & 5.00 & 6.77 \\
\hline Voids & ----- & ----- & 13.2 & 13.8 & 2.7 & 7.9 & 9.8 & $-\cdots-$ & ----- \\
\hline
\end{tabular}

$(\mathrm{ph})=$ Phenocrysts

$(\mathrm{mic})=$ Microlites 
Table 2 - Continued.

\begin{tabular}{|c|c|c|c|c|c|c|c|c|}
\hline \multirow{3}{*}{$\begin{array}{l}\text { Unit } \\
\text { Sample }\end{array}$} & \multicolumn{6}{|c|}{ Ellensburg Formation (Conglomerate Clasts) } & \multirow{2}{*}{$\begin{array}{c}\begin{array}{c}\text { Ellensburg } \\
\text { Formation } \\
\text { (Laharic } \\
\text { Clasts) }\end{array} \\
\mathrm{CCH}\end{array}$} & \multirow{3}{*}{$\begin{array}{c}\begin{array}{c}\text { Ellensburg } \\
\text { Formation } \\
\text { (Dacititc Lava) }\end{array} \\
\text { CCH } \\
94124\end{array}$} \\
\hline & $\mathrm{CCH}$ & $\mathrm{CCH}$ & $\mathrm{CCH}$ & $\mathrm{CCH}$ & & & & \\
\hline & 94029 & 94031 & 94039 & 94099 & Mean & SD & 94115 & \\
\hline Plagioclase (ph) & 27.3 & 20.4 & 23.0 & 24.7 & 23.85 & 2.90 & 22.9 & 34.4 \\
\hline Plagioclase (mic) & 12.5 & 26.3 & 67.2 & 30.4 & 34.10 & 23.36 & 63.2 & 17.0 \\
\hline Quartz (ph) & ---- & 3.4 & 0.6 & 0.1 & 1.03 & 1.60 & 0.9 & 0.1 \\
\hline Hornblende (ph) & 8.4 & 3.6 & 1.4 & 6.2 & 4.90 & 3.05 & 5.7 & 3.8 \\
\hline Biotite (ph) & 0.8 & 1.0 & 1.1 & 0.4 & 0.83 & 0.31 & 0.4 & 0.4 \\
\hline Orthopyroxene (ph) & 0.2 & 0.1 & 0.2 & 1.3 & 0.45 & 0.57 & 0.3 & 0.7 \\
\hline Orthopyroxene (mic) & trace & 0.1 & 0.4 & 0.2 & 0.18 & 0.17 & 2.0 & 0.6 \\
\hline Clinopyroxene (ph) & ---- & ----- & ---- & 0.4 & 0.10 & 0.20 & 0.2 & ---- \\
\hline Magnetite (ph) & 1.7 & 0.5 & 1.4 & 1.4 & 1.25 & 0.52 & 1.2 & 1.4 \\
\hline Magnetite (mic) & 1.1 & 2.0 & 4.7 & 2.0 & 2.45 & 1.56 & 3.6 & 2.0 \\
\hline Epidote & ---- & ---- & --- & ---- & ---- & $-\cdots-$ & 0.2 & ----- \\
\hline Groundmass & 47.9 & 42.6 & $-\cdots--$ & 32.9 & 30.85 & 21.48 & ---- & 30.2 \\
\hline Chlorite & $-\cdots-$ & $-\cdots-$ & $-\cdots-$ & ---- & $\cdots-$ & ---- & $--\cdots-$ & 9.4 \\
\hline Xenoliths & ---- & 1.1 & --- & $-\cdots-$ & 0.26 & 0.55 & ---- & 1.4 \\
\hline Voids & 5.1 & ----- & 1.0 & 4.1 & $\ldots--$ & $--\cdots-$ & 2.5 & ----- \\
\hline
\end{tabular}


Deuteric alteration has caused partial chloritization of hornblende and biotite. Such chloritization is due to late stage alteration by hydrothermal fluids at shallow depths. Chlorite is common along fractures near the margins of the main intrusion and within the sill to the west of old Scab Mountain.

\section{Plagioclase}

Plagioclase is the most abundant mineral in the old Scab Mountain dacitic rocks and comprises approximately 808 of the total rock volume, of which approximately 408 are phenocrysts and 608 groundmass. Plagioclase phenocryst crystal shapes are mainly tabular to equant with lengths ranging from 0.15 to 7.5 $\mathrm{mm}$ with the majority between 0.15 to $3 \mathrm{~mm}$. Groundmass is typically tabular to anhedral and have lengths between 0.006 to $0.15 \mathrm{~mm}$. Plagioclase in phenocryst and groundmass are generally distributed equally throughout the rock with very few glomerocrysts present. Crystal lath orientation is random, indicating minimal to no movement of magma during crystallization.

Plagioclase composition ranges from calcic andesine to sodic labradorite $\left(A n_{44}-A n_{56}\right)$; however, even more calcic plagioclase can be seen within the sill (Sample \#94019) which range from calcic andesine to calcic labradorite $\left(A n_{42}-A n_{63}\right)$. In general, the largest phenocrysts are the most calcic 
varieties, with the groundmass being the most sodic. However, the range in plagioclase composition is variable throughout the size ranges.

oscillatory zoning within the phenocrysts is common. Zoned plagioclase phenocrysts are most calcic within their cores and becoming more sodic outward. Several generations of crystal growth, melting and recrystallization have been identified optically in oscillatory zoning patterns within the plagioclase phenocrysts (Fig. 28). Very few phenocrysts are totally free from signs of zoning, and suggest a history of continuous thermal and/or chemical fluctuations during crystallization. Reaction rims containing fine-grained inclusions of hypersthene and magnetite are commonly seen in the largest plagioclase phenocrysts $(2$ to $7.5 \mathrm{~mm}$ in size) and indicate a latent stage of recrystallization possibly due to thermal influx.

At least four generations of plagioclase growth can be identified. The oldest generation is represented by some of the largest phenocrysts. These plagioclase phenocrysts are typically equant to subtabular and show the most extensive oscillatory zoning. Younger plagioclase phenocrysts are typically more tabular and show little to no oscillatory zoning. Within the matrix, two additional generations of plagioclase can be identified. The older generation is tabular and may represent a later nucleation stage of the 


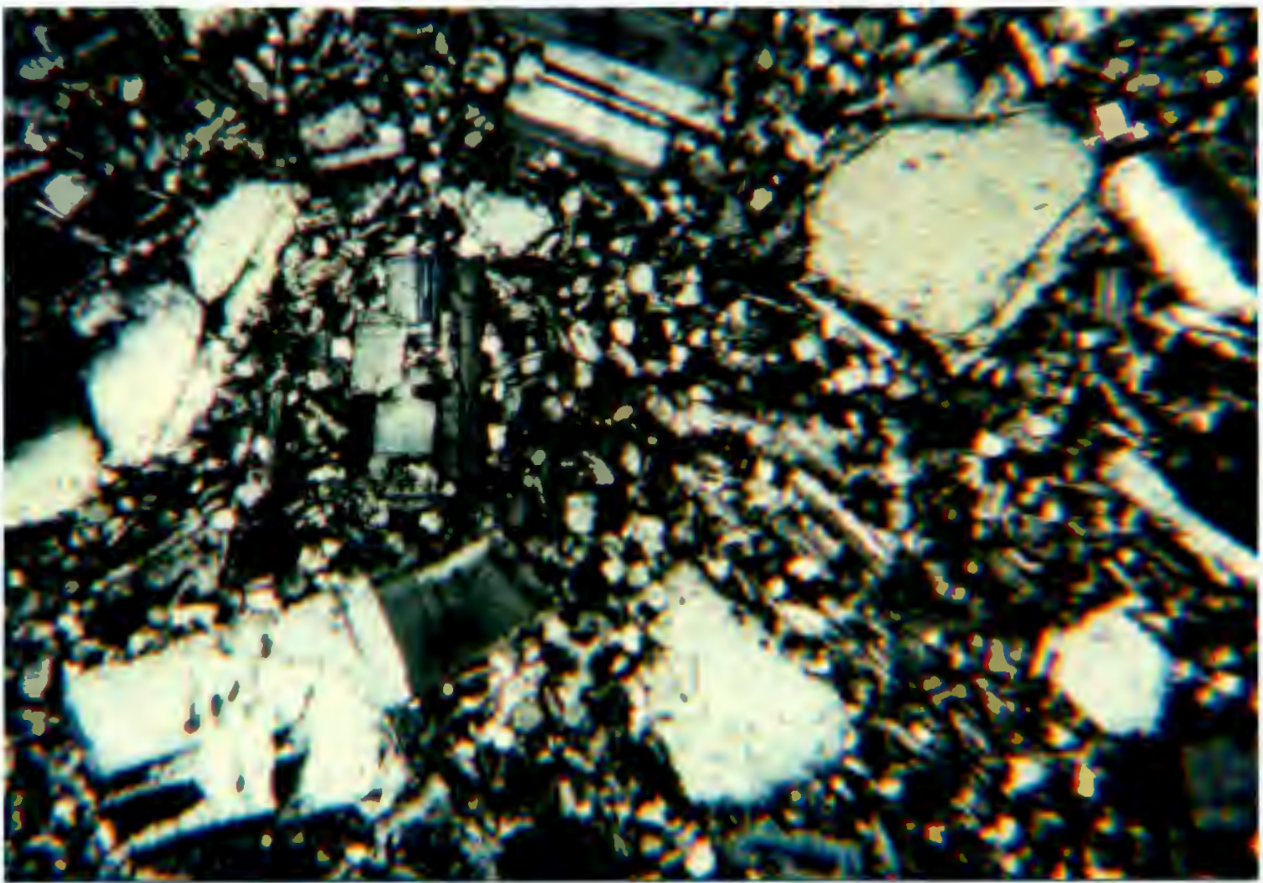

Figure 27 - Photomicrograph of dacite of Old Scab Mountain (50X, cross-polarized, sample \#94080).

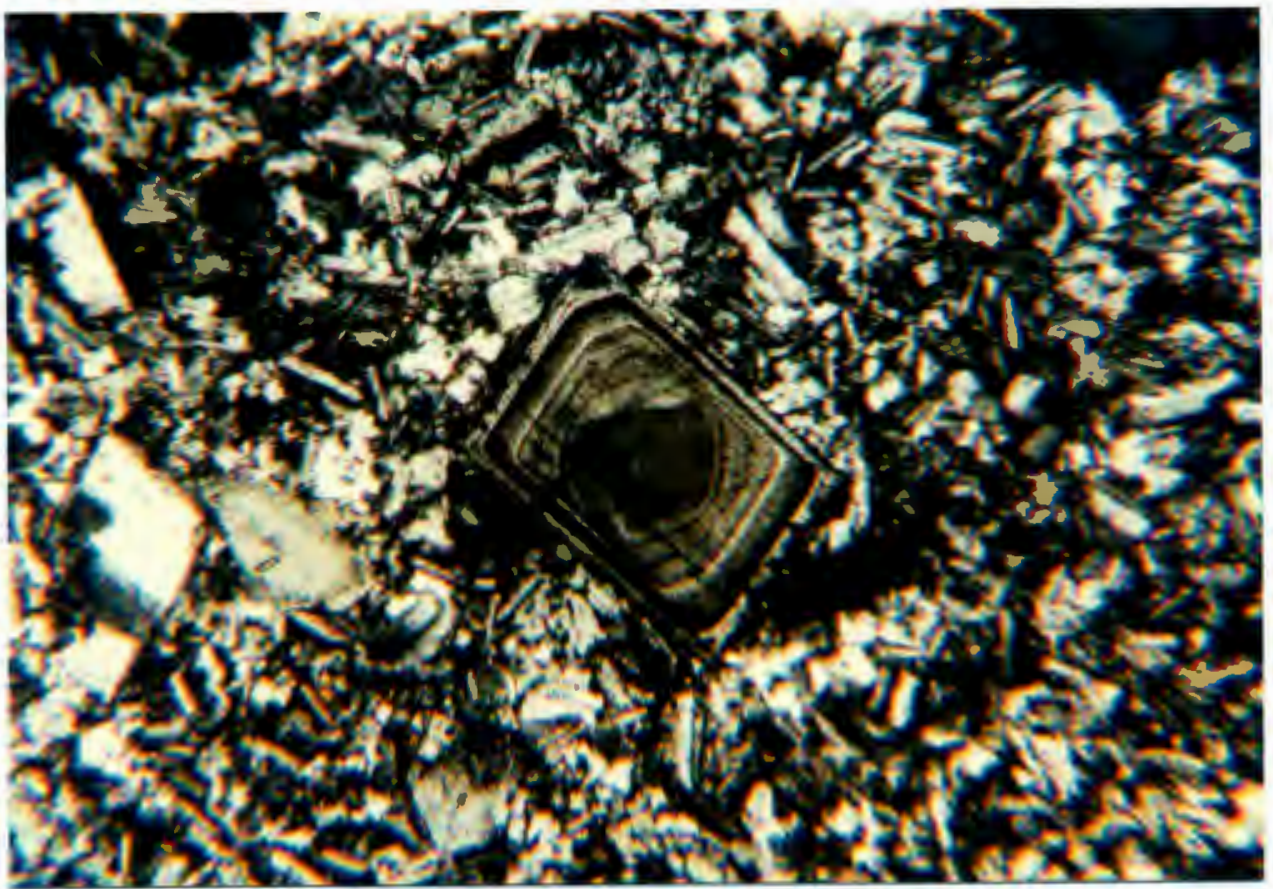

Figure 28 - Photomicrograph of zoned plagioclase crystal in dacite of Old Scab Mountain (50x, cross-polarized, Sample \#94079). 
tabular phenocryst form. The youngest plagioclase generation represents true groundmass and consist of equigranular, subhedral to anhedral crystals.

\section{Quartz}

Quartz ranges from trace to about 38 of the total rock volume within the intrusive body (Table 2); however, higher concentrations (up to 68 of the total rock volume) can be found within the sill to the west (Sample \#94019). Quartz phenocrysts range in size from 0.2 to $6.8 \mathrm{~mm}$ in diameter and are rounded to subrounded in shape. Commonly quartz phenocrysts cluster within a group surrounded by a groundmass of plagioclase and magnetite.

Overgrowth rims consisting of small tabular plagioclase crystals are commonly seen surrounding rounded quartz grains (Fig. 29). These rims measure in thickness from approximately $0.024 \mathrm{~mm}$ to $0.032 \mathrm{~mm}$. The most distinctive overgrowths are within the sill (\#94019) in which quartz can commonly be seen surrounding the plagioclase overgrowth (Fig. 29). The surrounding layer or "shell" of quartz is always in-phase with the parent quartz grain. Such overgrowths suggest that the liquidus composition during crystallization was near the equilibrium field of both quartz and plagioclase and that subtle shifts in either pressure or temperature resulted in changes in which mineral type crystallized. The rounding of 
the quartz grains suggests that the grains were partly resorbed into the melt prior to the formation of the plagioclase overgrowths. This would have formed a more silica rich magma surrounding the quartz grain which may have been favorable for plagioclase nucleation. When the system again became favorable for quartz crystallization the existing quartz grains grew larger, encompassing the overgrowths of small plagioclase crystals, and forming a surrounding layer or "shell" of quartz.

\section{Magnetite}

Magnetite occupies 1 to 58 of the total rock volume (Table 2) and forms subhedral to anhedral grains from 0.006 to $0.6 \mathrm{~mm}$ in diameter. Magnetite is typically found within the groundmass of the rock, within the center of many orthopyroxene clusters, and within the reaction rims of hornblende and biotite phenocrysts. Commonly, magnetite is also found as inclusions within hornblende and biotite phenocrysts. Phenocryst-sized magnetite crystals are rare. 
Ferromagnesium Silicates

Ferromagnesium silicate minerals in dacite of old Scab Mountain are of two types: (1) hydrous mafic phases; hornblende and biotite, and (2) anhydrous mafic phases; orthopyroxene with a lesser amount of clinopyroxene.

Hyarous phase stability is a function of pressure, temperature, and activity of $\mathrm{H}_{2} \mathrm{O}$. Decreases in pressure or increases in temperature can cause the release of $\mathrm{H}_{2} \mathrm{O}$ in hydrous phases resulting in recrystallization to anhydrous phases such as orthopyroxene.

Hornblende stability experiments at $800 \mathrm{MPa}$ show that hornblende is most stable (at $\sim 980^{\circ} \mathrm{C}$ ) when 4.5 weight percent $\mathrm{H}_{2} \mathrm{O}$ is present in the system (Naney, 1983). At lower $\mathrm{H}_{2} \mathrm{O}$ concentrations, hornblende is replaced by orthopyroxene, magnetite and plagioclase (Rutherford and Hill, 1993; Garcia and Jacobson, 1979; Jakeš and White, 1972). This type of amphibole reaction has been termed by Garcia and Jacobson (1979) as a 'gabbroic' type reaction and typically enriches the remaining melt in $\mathrm{SiO}_{2}, \mathrm{~K}_{2} \mathrm{O}$, and $\mathrm{Na}_{2} \mathrm{O}$ and depletes it in $\mathrm{Al}_{2} \mathrm{O}_{3}, \mathrm{FeO}$, and $\mathrm{CaO}$ (Rutherford and $\mathrm{Hill}, 1993$; Naney, 1983). Biotite at $800 \mathrm{MPa}$ is most stable (at $\sim 960^{\circ} \mathrm{C}$ ) at 7.5 weight percent $\mathrm{H}_{2} \mathrm{O}$. However, biotite remains stable even in relatively anhydrous conditions when $\mathrm{H}_{2} \mathrm{O}$ is less than 0.5 wt percent (200 to $800 \mathrm{MPa})$. This suggests that biotite 
continues to remain stable under drier conditions than those required for hornblende (Naney, 1983). Under unstable conditions biotite is replaced by orthopyroxene, magnetite and feldspar (Naney, 1983; Mueller, 1972).

The replacement of hydrous phase mineral was common in the dacite of old Scab Mountain. Consequently, hornblende and biotite make up less than $2 \frac{q}{z}$ of the mineral assemblage. The least amount of replacement is observed in the sill and is attributed to a more rapid cooling rate.

Hornblende and biotite phenocrysts are typically surrounded by fine- to medium-grained aggregates of orthopyroxene, magnetite and plagioclase minerals (Figs. 30 and 31). More commonly, total replacement of the original hornblende and biotite phenocrysts occurs and a fine-grained clot of breakdown products remains (Fig. 32). Where such crystal clots are present, identification of the original hydrous mineral is difficult because both hornblende and biotite are replaced by the same mineral assemblage.

orthopyroxene is the most common reaction rim mineral, making up 40 to $90 \%$ of the total products. Magnetite makes up 10 to 308 of the reaction rim minerals and is normally found interspersed throughout the orthopyroxene, or concentrated within the inner or central part of the rim. Plagioclase, where present, occupies the inner most part of the rim and is commonly found within the center of the fine-grained clot. 


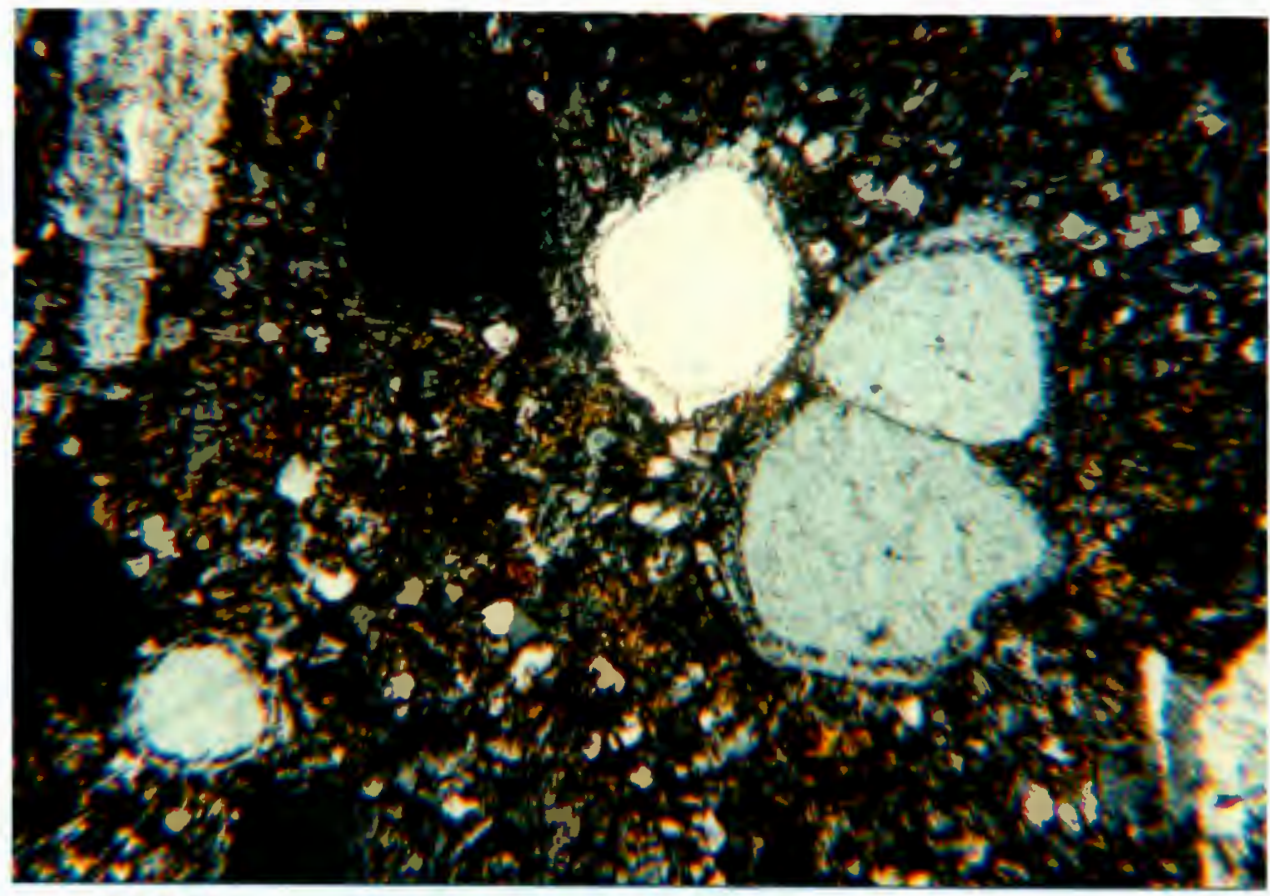

Figure 29 - Photomicrograph of quartz grains with overgrowths of plagioclase surrounded by an additional layer or "shell" of quartz in dacite of old Scab Mountain (50x, cross-polarized, Sample \#94019).

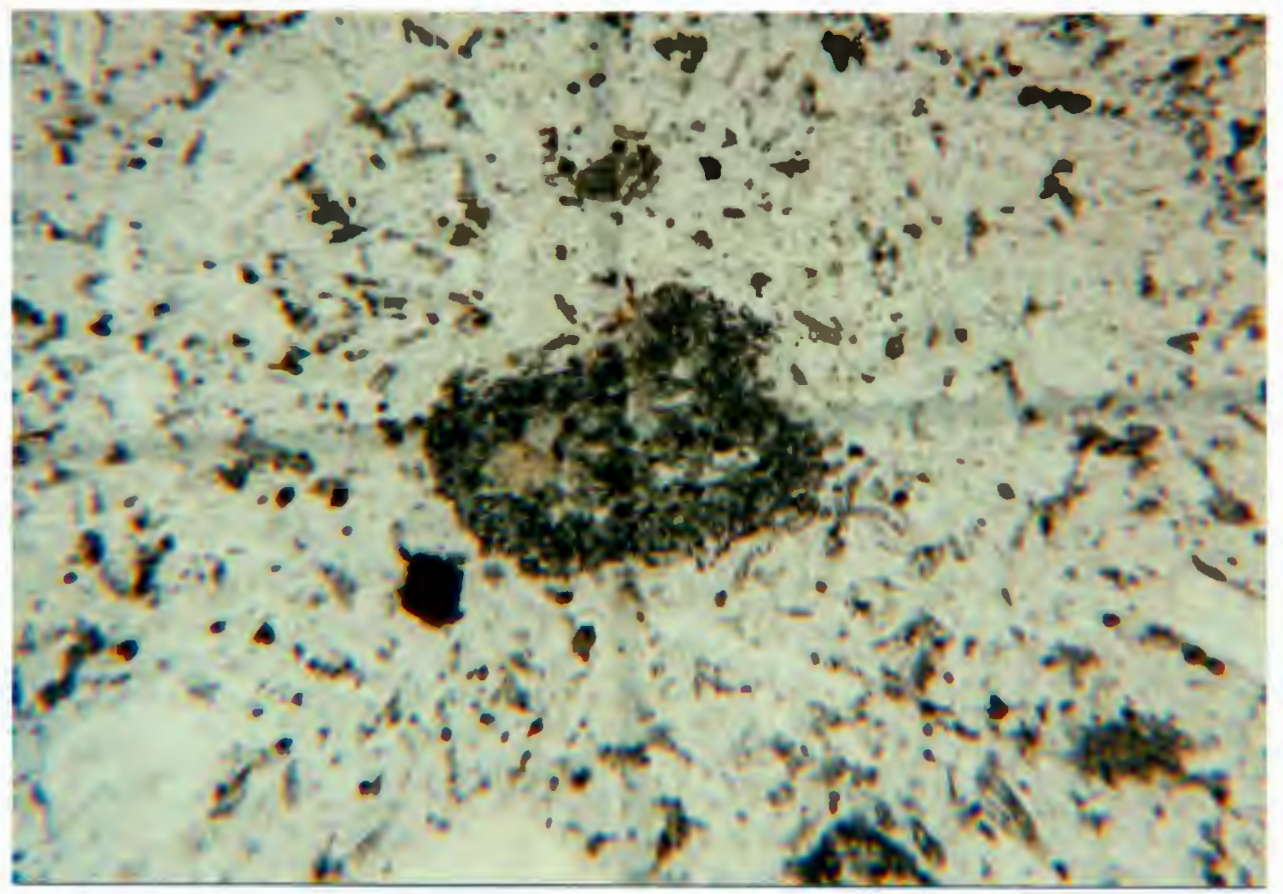

Figure 30 - Photomicrograph of hornblende with reaction rim of orthopyroxene, magnetite and plagioclase in dacite of old scab Mountain (50X, plain-polarized, sample \#94079). 


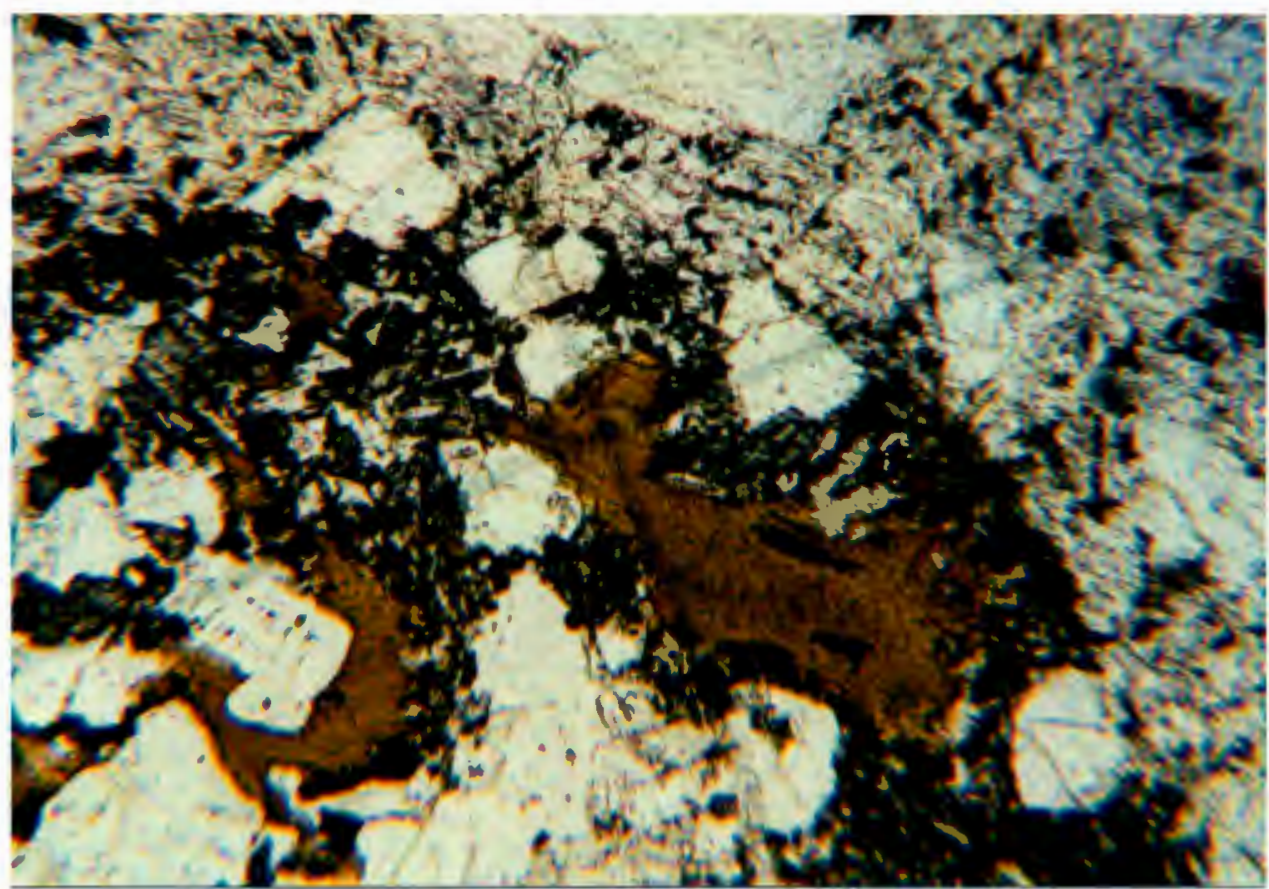

Figure 31 - Photomicrograph of biotite with reaction rim of orthopyroxene, magnetite and plagioclase in dacite of old scab Mountain (50X, plain-polarized, Sample \#94080).

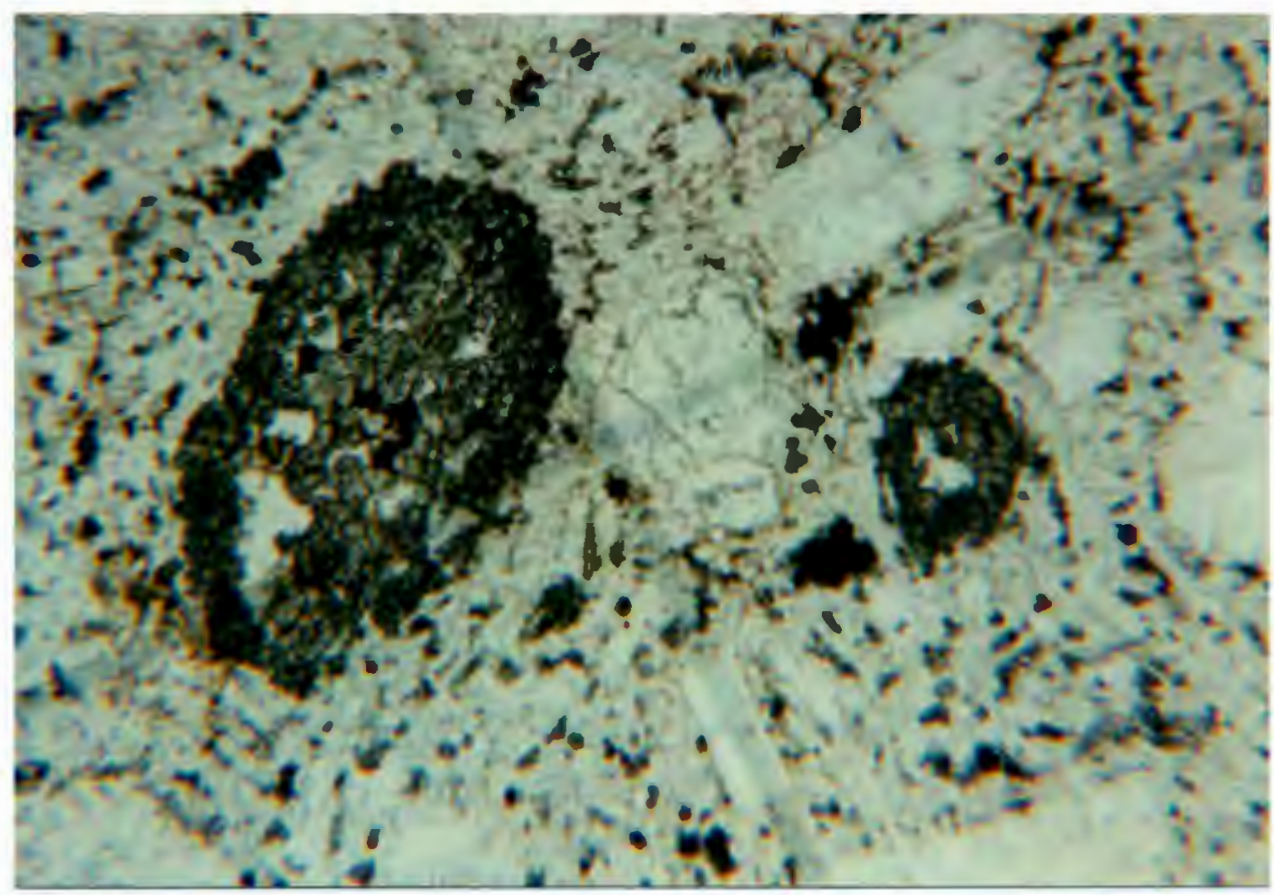

Figure 32 - Photomicrograph of aggregation of breakdown minerals (orthopyroxene, magnetite and plagioclase) in dacite of old Scab Mountain. The original parent mineral has been completely replaced (50x, plain-polarized, Sample \#94080). 
Minerals which have been completely re-crystallized typically lack plagioclase and are almost exclusively orthopyroxene and magnetite. Where plagioclase is present, commonly only a single crystal in the center of the crystal clot can be identified.

Biotite reaction rims are zoned with an outer rim of orthopyroxene, a central rim of magnetite, and an inner rim of plagioclase (Fig. 31).

HORNBLENDE

Hornblende composes 0.1 to 2 of the rock volume with the average being approximately 0.28 . The highest concentration of hornblende is found within the sill. Crystals are anhedral to subhedral and commonly have an irregular prismatic or pseudohexagonal habit (Fig. 33). Crystal size is from 0.2 to $0.8 \mathrm{~mm}$ in diameter; however, diameter size including the reaction rims can reach up to 2.5 mm. Mineral grains are pleochroic with color varying from pale green to brown.

Within old Scab Mountain dacite almost all hornblende has re-crystallized to orthopyroxene, magnetite and plagioclase. Initial hornblende concentration prior to mineral breakdown may have been as high a $10 \%$ based on percentage of fine-grained orthopyroxene and magnetite present. 


\section{BIOTITE}

Biotite is 0.2 to 18 by volume. Phenocrysts range in size from 0.2 to $1.5 \mathrm{~mm}$ not including reaction rims, and 2 to $3 \mathrm{~mm}$ including reaction rims. Crystal habits are anhedral to subhedral with a few euhedral hexagonal or tabular shapes. Pleochroic color variations range from light greenish-brown to brown. Inclusions of cubic magnetite $(<0.1 \mathrm{~mm})$ are common. Replacement of primary biotite resulting from decompression lead to the formation of reaction rims of outer orthopyroxene, central magnetite and inner plagioclase (Fig. 31). Total breakdown of biotite is less complete than in hornblende. Concentration of biotite in initial crystallized dacite prior to reaction was possibly from 1 to $3 \%$. Secondary chlorite alteration is common within the western sill and along the margins of the main intrusive body.

\section{ORTHOPYROXENE}

orthopyroxene occupies 3.4 to 128 of the total rock volume and typically is less than $0.1 \mathrm{~mm}$ in size, although phenocrysts as large as $1.5 \mathrm{~mm}$ are present in trace amounts (Fig. 34). Crystal habit is anhedral to subhedral tabular in shape. Optic signs are normally (-) suggesting that hypersthene rather than enstatite is the dominant orthopyroxene present. Pleochroism is slight, ranging in color from neutral to very pale green/brown. 


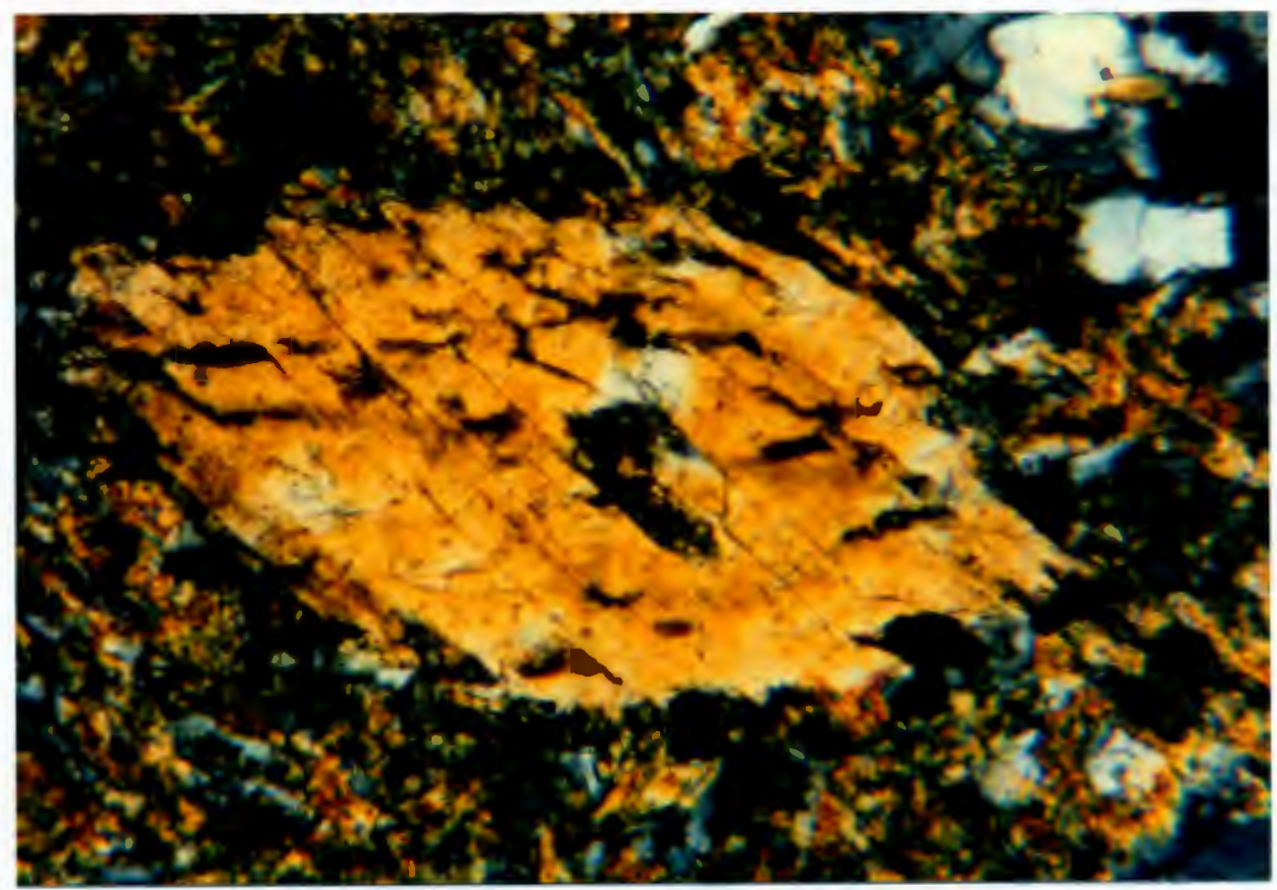

Figure 33 - Photomicrograph of pseudohexagonal hornblende phenocryst with reaction rim of orthopyroxene, magnetite and plagioclase in dacite of old scab Mountain (200X, crosspolarized, Sample \#94020).

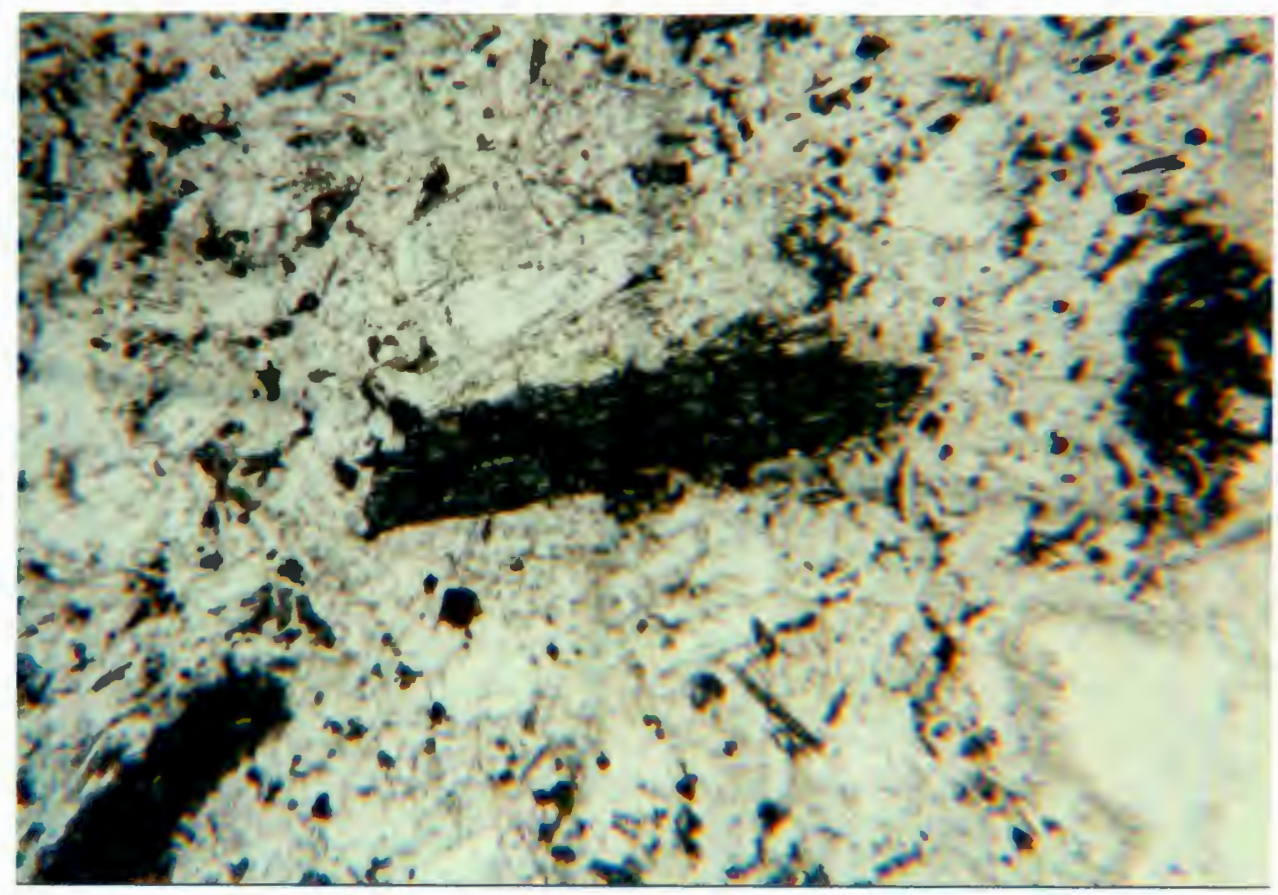

Figure 34 - Photomicrograph of orthopyroxene phenocryst crowded with magnetite with orthopyroxene microlites in matrix in dacite of old Scab Mountain (50X, plain-polarized, Sample \#94079). 
Approximately $50 \%$ of fine-grained orthopyroxene is interstitial. The other 508 clusters as fine-grained clots or surrounding hornblende and biotite as reaction rims. Finegrained orthopyroxene inclusions are commonly found within large (> $2 \mathrm{~mm}$ ) phenocrysts of plagioclase.

orthopyroxene phenocrysts are typically euhedral to subhedral and range in size from 0.2 to $1.3 \mathrm{~mm}$. Phenocrysts of orthopyroxene typically contain interstitial magnetite less than $1 \mathrm{~mm}$ in size.

\section{CLINOPYROXENE}

Clinopyroxene was observed only within the dacite sill (Sample \#94019). Clinopyroxene occupies 0.28 of the total volume of the sill. Phenocrysts ranged from 0.3 to $0.5 \mathrm{~mm}$ in size and are anhedral in habit. Optical crystal sign is $(+)$. Coloration is pale green with no pleochroism.

Inclusions of cubic magnetite, less than $0.1 \mathrm{~mm}$ in diameter, are present within the clinopyroxene phenocrysts. Clinopyroxene phenocrysts have reaction rims of fine-grained, anhedral magnetite and plagioclase, less than $0.2 \mathrm{~mm}$ in size.

\section{ELLENSBURG FORMATION}

Petrographic analysis was conducted on 13 samples collected from the Ellensburg Formation. Of these samples, 7 are dacitic clasts collected from pyroclastic flow deposits, 3 
are dacitic clasts collected from conglomerates, 1 is a dacitic clast collected from a lahar flow deposit, and one is a dacitic lava flow (Table 2). The primary focus of this petrographic study is to compare dacites from the upper Ellensburg Formation with dacites of Old Scab Mountain. No petrographic analysis was conducted on rock samples collected from the lower Ellensburg Formation. Petrographic studies of sedimentary rock has previously been conducted by coombs (1941), Schmincke (1964) and Luker (1985).

Dacitic clasts are highly porphyritic with phenocrysts of plagioclase, quartz, biotite, hornblende, orthopyroxene and magnetite (Fig. 35). Phenocrysts occupy 25 to 408 of rock volume and consist primarily of plagioclase. groundmass is crystalline to partly glassy and consists chiefly of plagioclase with lesser amounts of orthopyroxenes and magnetite.

Primary texture is porphyritic with a hyalopilitic to cryptocrystalline groundmass. A pilotaxitic groundmass is also common where microlites are subparallel and flow around the larger phenocrysts. This texture occurs in many of the more open-textured dacitic clasts and within the lava flow, and indicates flowage prior to final solidification. Percentage of void space, or vesicles, within clasts is variable and is dependent on the degree of devolatilization during cooling. Tuff clasts contain the highest percentage of 
void spaces (up to 148 void space) with conglomerate and laharic clasts containing lesser amounts. The dacitic lava flow sample contained no void spaces.

\section{Plagioclase}

Plagioclase comprises from 35 to as much as 908 of the total rock volumes. Of this, approximately 11 to 358 are phenocrysts and 12 to 568 are microlites. The lowest plagioclase percentages are found in rocks with a high percentage of cryptocrystalline or glassy groundmass. Phenocrysts range in size from 0.15 to $5.2 \mathrm{~mm}$ with the majority ranging between 0.15 and $2.5 \mathrm{~mm}$, and have tabular to equant crystal forms. Groundmass plagioclase is typically tabular to anhedral and are less than $0.15 \mathrm{~mm}$. In samples which have experienced rapid cooling (tuff and lava flow samples), groundmass is typically more tabular when compared to those samples which cooled at a slower rate, however, crystal forms are variable. Commonly, plagioclase laths are aligned in a preferred orientation and flow around larger phenocrysts. This is especially notable in many of the samples collected from tuff deposits. The dacitic lava flow also shows a flow banded texture; however, because the groundmass is primarily composed of glass, flow alignment is primarily in the phenocrysts. 
Plagioclase composition ranges from calcic andesine to calcic labradorite $\left(A n_{44}-A n_{66}\right)$; however, more typical values range from $A n_{50}-\mathrm{An}_{60}$. Plagioclase microlites generally fall within the lower end of the anorthite scale ranging from calcic andesine to sodic labradorite.

Oscillatory zoning within the phenocrysts is common; however, not as common as in samples from old scab Mountain. Unlike Old Scab Mountain samples, oscillatory zoned phenocrysts in Ellensburg rocks are commonly side by side with unzoned phenocrysts. Total zoned phenocrysts range from 30 to 508 of total plagioclase phenocrysts. Zoned phenocrysts become more sodic outward and commonly show an abrupt calcic increase before becoming more sodic once again. Such variation may be the result of magma mixing prior to ascent and cooling, or changes in pressure and $\mathrm{pH}_{2} \mathrm{O}$.

The largest phenocrysts are "pitted", showing irregular boundaries and internal voids occupied by later forming minerals (Fig. 36). Such "pitting" indicates destabilization of the plagioclase and partial resorption. Other plagioclase phenocrysts are blackened by cryptocrystalline Fe-Ti oxides which may have occurred during partial remelting of the phenocryst. These phenocrysts are uncommon and typically rimmed with unaltered plagioclase from 0.2 to $0.5 \mathrm{~mm}$ thick. 


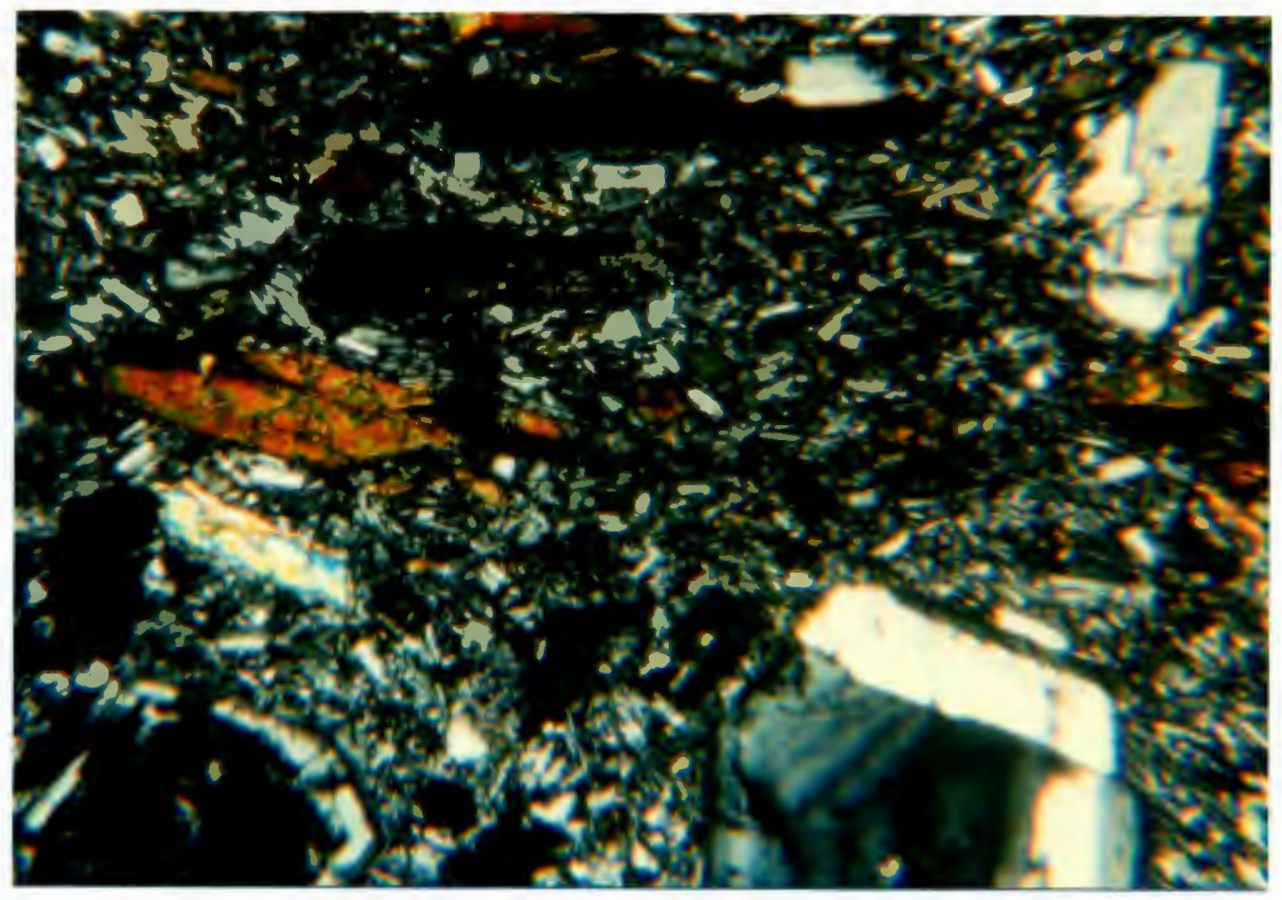

Figure 35 - Photomicrograph of dacite clasts in upper Ellensburg Formation (50x, cross-polarized, Samples \#94115).

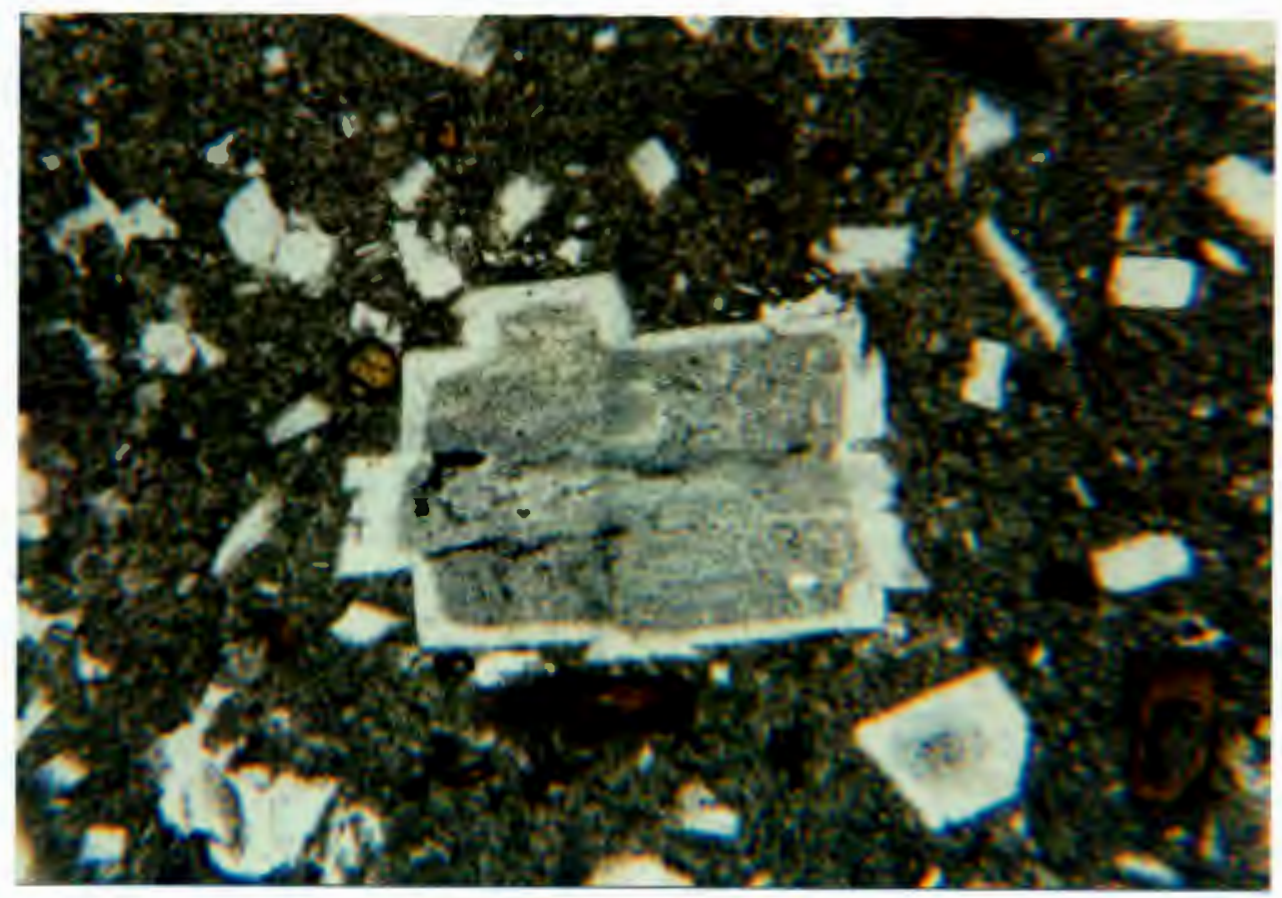

Figure 36 - Photomicrograph of "pitted" plagioclase phenocryst in dacite clast found in a pyroclastic flow in the upper Ellensburg Formation (50x, plain-polarized, Sample \#94092). 
Quartz

Quartz ranges from 08 to 3.48 of the total rock volume, with typical values from 0.2 to 0.58 (Table 2). Quartz phenocrysts range in size from 0.15 to $1.4 \mathrm{~mm}$, with the majority from 0.2 to $0.8 \mathrm{~mm}$. Grain shapes are rounded to subrounded and generally remained isolated from other phenocrysts, although sporadic clustering of quartz grains or quartz grains with other phenocrysts do occur.

Overgrowth rims consisting of small tabular plagioclase crystals surrounding rounded quartz grains have been observed in several conglomerate clast samples. Rim thickness ranges from 0.025 to $0.03 \mathrm{~mm}$. An outer layer or "shell" of quartz surrounding the plagioclase rims, as seen around quartz grains in the sill, is not present in the Ellensburg rocks.

\section{Magnetite}

Magnetite occupies 2 to $5 \%$ of the total rock volume (Table 2). Magnetite occurs as subhedral to anhedral grains that range from 0.04 to $0.5 \mathrm{~mm}$ in diameter. Subhedral grains form crude cubic or octahedral shapes. Magnetite microlites make up the majority of the grains with phenocrysts ranging from 0.5 to $2.5 \%$ of the rock volume. Magnetite is commonly found in the groundmass of the samples; however, its greatest 
concentration occurs within the reaction rims of hornblende and biotite. Commonly magnetite is an inclusion mineral within plagioclase, hornblende, biotite and pyroxene phenocrysts.

Ferromagnesium silicates

Four types of ferromagnesium silicate minerals occur in dacite of the Ellensburg Formation: (1) hornblende, (2) biotite, (3) orthopyroxene, and (4) clinopyroxene. A detailed discussion of the properties of these minerals and their stability relationships are discussed in the old Scab Mountain petrographic section of this thesis.

HORNBLENDE

Hornblende makes up 1.3 to 8.48 of the total rock volumes with the typical sample ranging from 3 to 48 (Table 2). Hornblende grains range in size from 0.1 to $4.5 \mathrm{~mm}$ in size; all form phenocrysts. Crystals are anhedral to euhedral and are commonly prismatic to pseudohexagonal. Mineral grains are pleochroic with color variations from pale green to brown, to partly opaque.

Opaque, opacitized hornblende minerals are the result of the crystallization of very fine-grained iron ore and pyroxene as the result of oxidation and dehydrogenation after extrusion of the melt (Rutherford and Hill, 1993; Garcia and Jacobson, 
1979) (Fig. 37). This type of reaction has been termed by Garcia and Jacobson (1979) as a 'black' type reaction, as the result of the black, opaque optical property of the crystal. However, this type of reaction in Ellensburg rocks is selective and commonly opaque hornblende minerals are in close proximity to non-opaque hornblende. The greatest occurrence of black hornblende is within tuff deposits where water and oxygen is readily transported through the unit after deposition.

'Gabbroic' type hornblende reactions, where hornblende is wholly or partially replaced by a fine- to medium-grained pyroxene-plagioclase-magnetite aggregate (Garcia and Jacobson, 1979), are generally less common in the Ellensburg Formation than in dacite of old Scab Mountain. Several tuff and conglomerate clasts show thin reaction rims of orthopyroxene, plagioclase, and magnetite microlites; however, extensive or total breakdown of hornblende phenocrysts as seen in old scab Mountain (Fig. 32) was not observed. The lack of 'gabbroic' type reactions may also account for the higher percentage of hornblende phenocrysts and lower percentage of orthopyroxene microlites in the Ellensburg Formation rocks than in the old Scab Mountain rocks (Table 2 ).

Overgrowth of hornblende around phenocrysts of pyroxene is seen in many samples and is attributed to reduction of pressure during the initial ascent of magma from the middle to 
upper crust. At lower pressures $\mathrm{H}_{2} \mathrm{O}$ is incorporated into the mineral structure and the hydrous phase becomes dominant. However, if pressure continues to decrease without change in temperature the hydrous phase becomes unstable and $\mathrm{H}_{2} \mathrm{O}$ is released from hornblende resulting in a 'gabbroic' type reaction. The lack of temperature change with pressure reduction suggests a rapid ascent, possibly as the result of a volcanic eruption.

BIOTITE

Biotite occupies 0.4 to 1.08 of the total rock volume with typical samples ranging from 0.6 to 0.88 (Table 2). Biotite phenocrysts range from 0.3 to $3.7 \mathrm{~mm}$ in diameter; typically 0.5 to $1.0 \mathrm{~mm}$. Crystal shapes are anhedral to subhedral. Crystal forms are crudely hexagonal to tabular. Pleochroic colors vary from light green to brown.

Microlite inclusions are commonly subhedral magnetite and anhedral plagioclase. Rare reaction rims 0.05 to $0.2 \mathrm{~mm}$ in thickness consist of orthopyroxene, magnetite and plagioclase (Fig. 38). Biotite reaction rims around pyroxene was not observed. Phenocryst clots of biotite, plagioclase, and pyroxene with hornblende overgrowths have been observed. Such crystal clots suggest that biotite was stable and had crystallized prior to the crystallization of hornblende, in the form of overgrowths around pyroxene phenocrysts. 


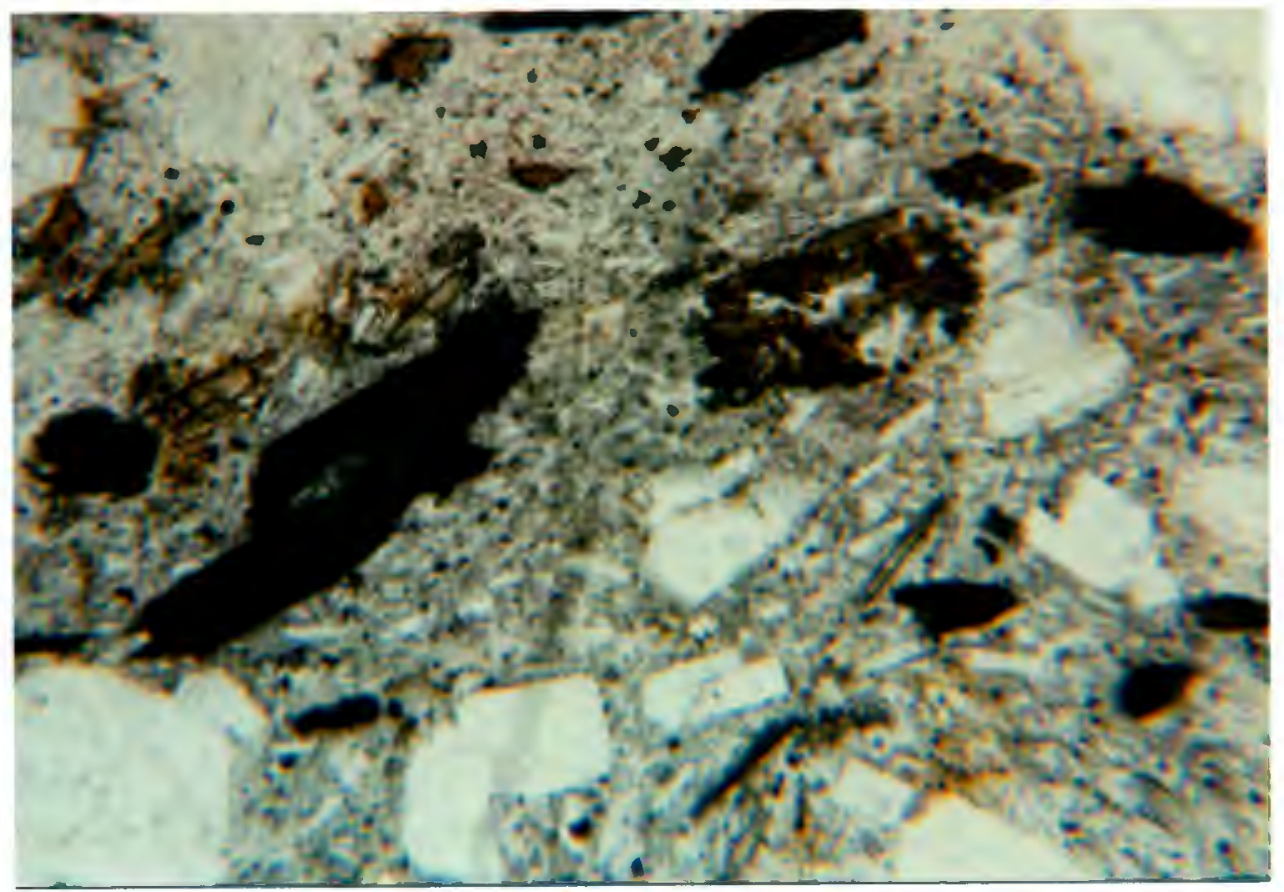

Figure 37 - Photomicrograph of 'black' type reaction of hornblende phenocryst in dacite clasts found in a lahar flow in the upper Ellensburg Formation (50X, plain-polarized, Sample \#94115).

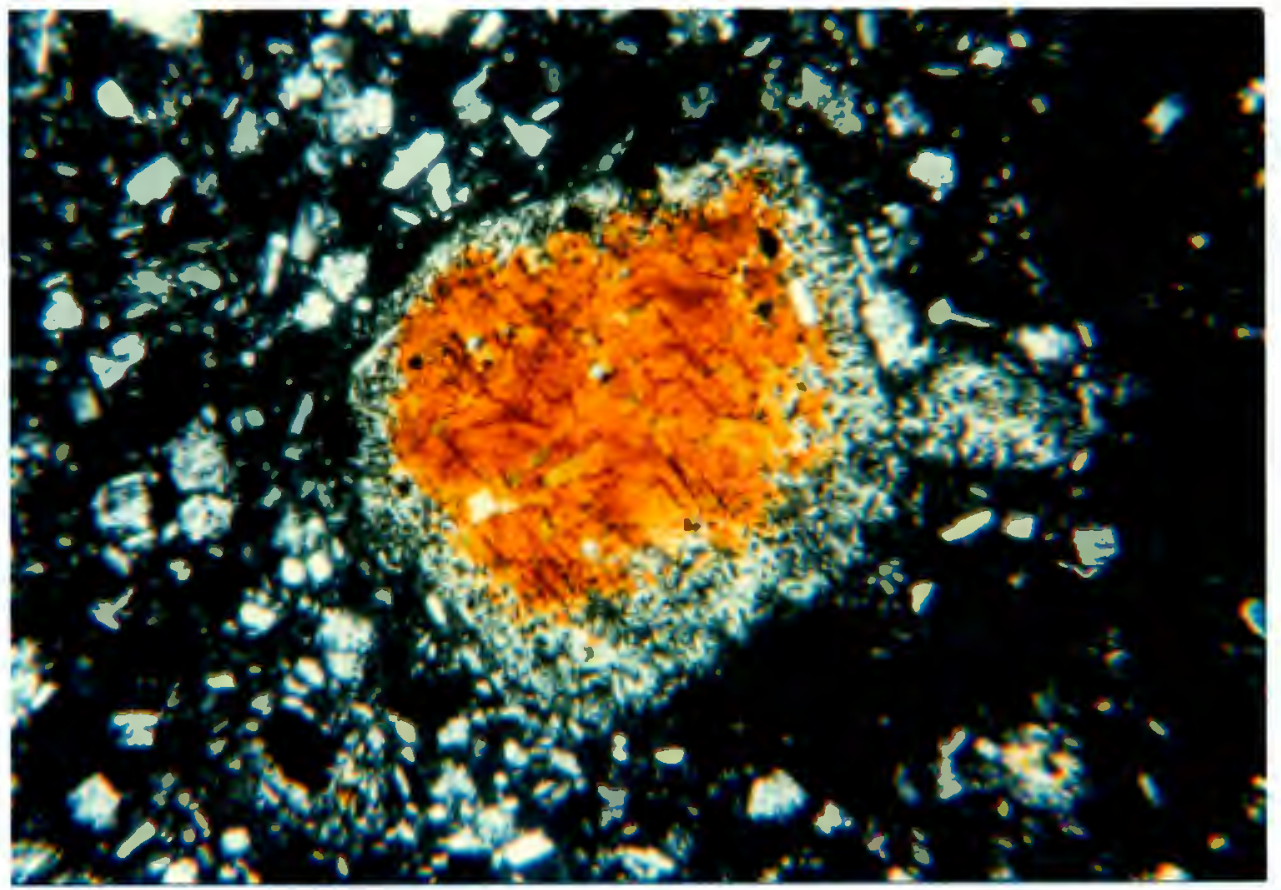

Figure 38 - Photomicrograph of biotite phenocryst with orthopyroxene, magnetite and plagioclase reaction rim in dacite clast found in a pyroclastic flow in the upper Ellensburg Formation (50X, cross-polarized, Sample \#94010). 


\section{ORTHOPYROXENE}

Orthopyroxene occupies approximately 0.2 to 3.08 of the total rock volumes with typical samples ranging from 0.7 to 1.28 (Table 2). Unlike rocks samples collected from old Scab Mountain, Ellensburg Eormation samples contain fewer orthopyroxene microlites. The ratio between orthopyroxene phenocryst and microlites varies from $1: 2$ to $1: 3$. Phenocryst crystals are anhedral to subhedral with tabular crystal forms and range in size from 0.1 to $1.7 \mathrm{~mm}$. Microlite habits are subhedral with crudely tabular crystal forms and range in size from 0.05 to $0.1 \mathrm{~mm}$. Optic signs are (-) suggesting hypersthene as the crystal phase; however, several phenocrysts reveal a (+) crystal sign, indicating enstatite. Pleochroism is slight, ranging in color from neutral to very pale greenish-brown.

Orthopyroxene phenocrysts commonly have overgrowths of hornblende which formed as the result of pressure decrease. orthopyroxene microlites typically form reaction rims around hornblende and, to a lesser extent, biotite. These reaction rims range in thickness from 0.05 to $0.2 \mathrm{~mm}$ and include microlites of magnetite and plagioclase. Orthopyroxene microlites are also found within the groundmass of the rock, even where reaction rims around hornblende or biotite are absent. 


\section{CLINOPYROXENE}

Clinopyroxene is rare and occurs primarily as phenocrysts. It is unclear whether clinopyroxene microlites are present within reaction rims around hornblende or biotite, within the groundmass or both. All analyzed pyroxene microlites reveal parallel extinctions with (-) optic signs; however, many microlites are too small to determine crystal properties. Clinopyroxene occupies up to 0.48 of the rock volumes. Crystals range in size from 0.2 to $1.1 \mathrm{~mm}$ in diameter and form anhedral to subhedral crudely tabular crystals. Pleochroism is slight and ranges from neutral to very pale green.

\section{XENOLITHS}

Dacitic xenoliths have been found in 5 of the 13 petrographically analyzed Ellensburg Formation clasts (Table 2). The highest occurrence of xenoliths occur within tuff clasts; however, xenoliths are also found in one analyzed conglomerate clast and within the lava flow. Xenoliths occupy 1.1 to 12.98 of the total rock volume of these samples. Sample \#94056 contains the highest percentage of xenoliths with 12.98 . Xenoliths are typically porphyritic with phenocrysts of plagioclase, hornblende and magnetite. Groundmass is crystalline and consists primarily of 
plagioclase. Xenoliths are rounded to subrounded and are interpreted as a result of partial melting of the xenoliths. Observed xenoliths range in size from 0.5 to $2.5 \mathrm{~mm}$.

\section{PETROGRAPHIC COMPARISION}

Petrographic comparison between the dacite of old Scab Mountain and dacite clasts in the Ellensburg Formation are difficult. Dacite of old Scab Mountain is intrusive in origin and had a relatively uniform and long cooling period. Whereas, the volcanic rocks of the Ellensburg Formation are extrusive rocks and cooled rapidly. The dacite of old scab Mountain is holocrystalline and lacks flow textures. Most of the Ellensburg dacite clasts have a fine-grained and glassy groundmass and commonly have aligned grains indicating flowage prior to cooling. However, the most distinctive difference is the degree of 'gabbroic' type reaction seen in the two units. Dacite of old Scab Mountain shows almost complete reaction of hydrous phases to orthopyroxene, plagioclase and magnetite; whereas, dacitic clasts in the Ellensburg Formation show only slight reaction. The significance of this observations is discussed below. 
GEOCHEMISTRY

Geochemical analysis of 122 samples collected within the Nile basin and adjacent areas was conducted. Of these samples, 83 are of volcaniclastic materials from the Ellensburg Formation, 17 are of dacitic intrusive rocks (of which 7 are dacites of Old Scab Mountain), 8 are of the Grande Ronde Basalt of the Columbia River Basalt Group, 6 are from the Fifes Peaks Formation, 3 are of the Bumping River tuff, and 5 are from the Ohanapecosh Formation. X-ray fluorescence (XRF) was used to identify major and trace elemental concentrations in all 122 samples, and instrumental neutron activation analysis (INAA) was used to identify major, trace and rare earth elemental concentrations in 45 samples. Non-normalized analytical results, general sample descriptions, and locations are given in Appendices A-D. Sample locations are shown on Plate 1. All geochemical data portrayed in the following figured diagrams have been normalized to 1008 of the total element concentration.

\section{MAJOR ELEMENTS}

Samples collected from the Ellensburg Formation within the Nile basin range in silica content from 59 to 758 . The majority of the samples are within the dacite range (63 to 68 weight percent $\mathrm{SiO}_{2}$ ) as classified by the total alkali-silica (TAS) diagram (Fig. 39). A few samples are high in silica, 


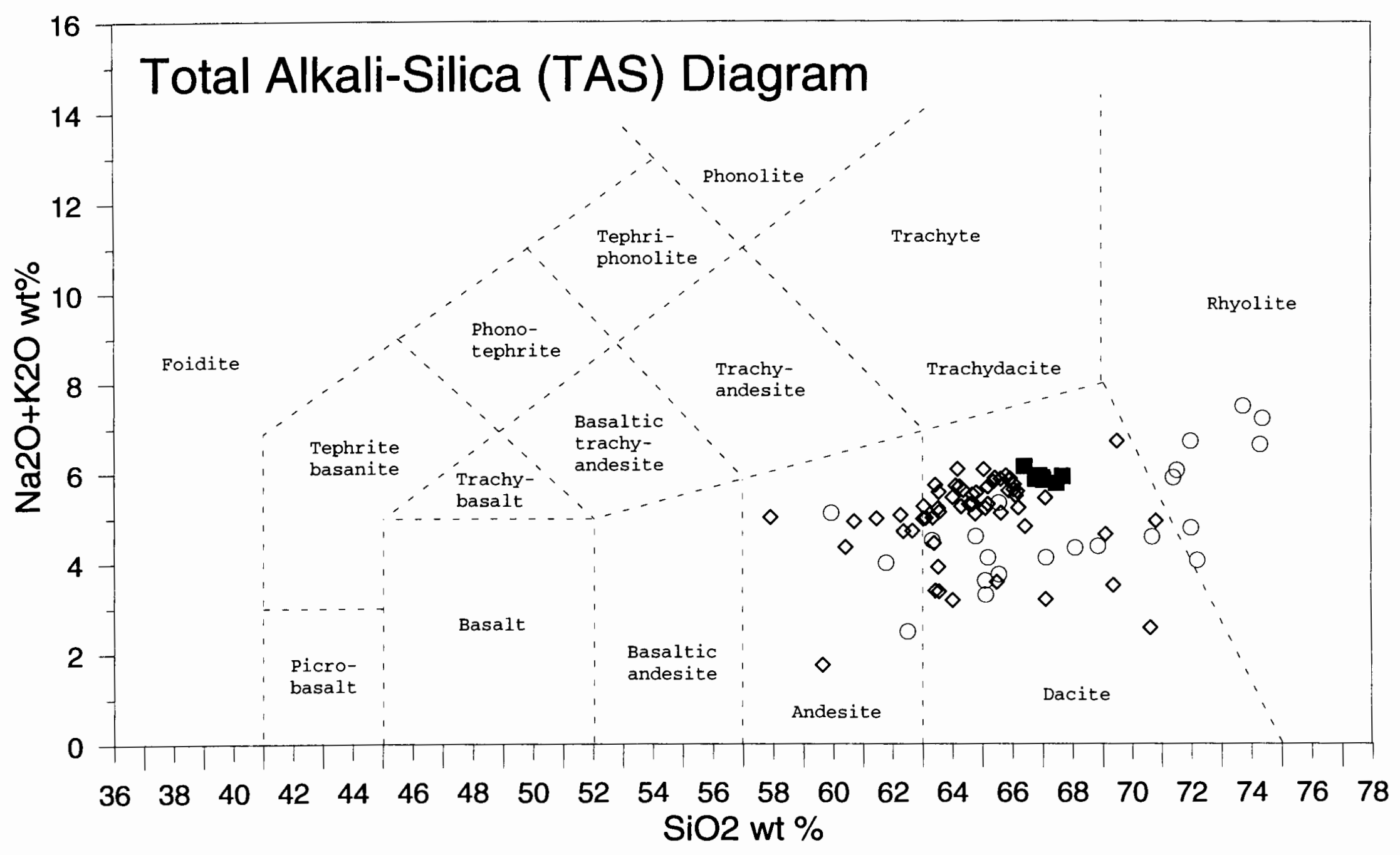

Figure 39 - Total Alkali-Silica (TAS) Diagram of lower Ellensburg rocks (open circles), upper Ellensburg rocks (open diamonds) and dacites from old Scab Mountain (closed squares). 
ranging from 71 to 75 weight percent $\mathrm{SiO}_{2}$, and are typically associated with the lower Ellensburg Formation. Samples of the lower Ellensburg Formation also show lower alkali concentration than most of the upper Ellensburg Formation samples. These differences are illustrated by two general linear distributions with the majority of the upper Ellensburg samples plotting with higher alkali values and a narrower range in silica content then the majority of the lower Ellensburg samples (Fig. 39).

Dacitic intrusive rocks range in silica content from 64 to 67 weight percent $\mathrm{SiO}_{2}$, with dacites of old Scab Mountain ranging from 66 to 67 weight percent $\mathrm{SiO}_{2}$. This silica range falls within the upper limits of the main cluster of upper Ellensburg Formation samples (Fig. 39).

The majority of Ellensburg samples plot in the calcalkaline field of the AFM diagram (Fig. 40). Tholeittic rocks are more common in the lower Ellensburg Formation. Dacite samples from Old Scab Mountain and upper Ellensburg samples fall within the same distribution in the calc-alkaline field (Fig. 40)

Harker variation diagrams of the major elements ( $\mathrm{K}, \mathrm{Na}$, $\mathrm{Al}, \mathrm{Ti}, \mathrm{Mg}, \mathrm{Fe}, \mathrm{Ca}, \mathrm{Mn}$, and $\mathrm{P}$ ) are shown in Figure 41 . These diagrams show the concentrations of major element oxides with increasing $\mathrm{SiO}_{2}$ for all analyzed Ellensburg Formation samples and dacitic intrusive rocks. 


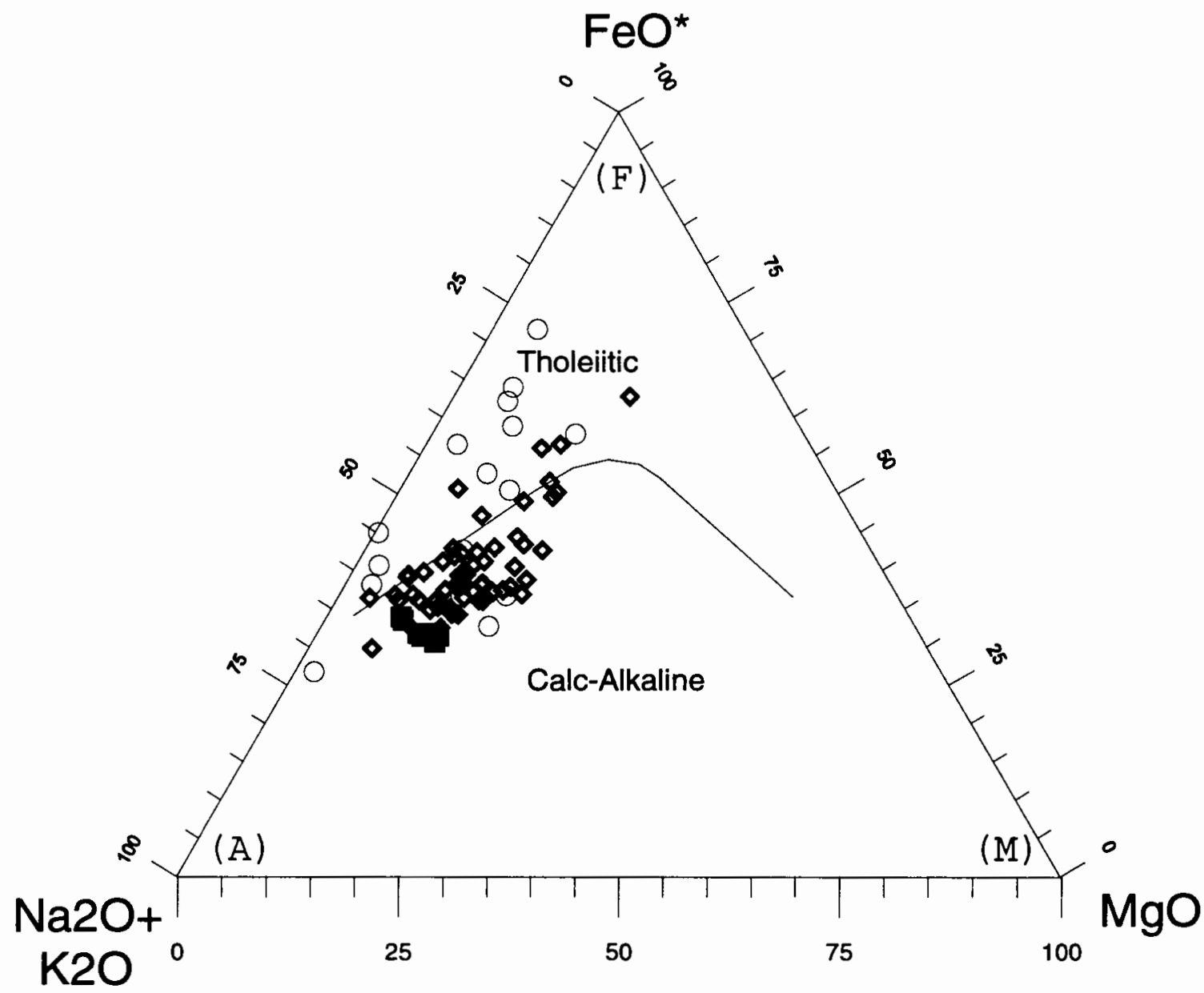

Figure 40 - AMF diagram of lower Ellensburg rocks (open circles), upper Ellensburg rocks (open diamonds) and dacites from old Scab Mountain (closed squares). Plot after Irvine and Baragar (1971). 

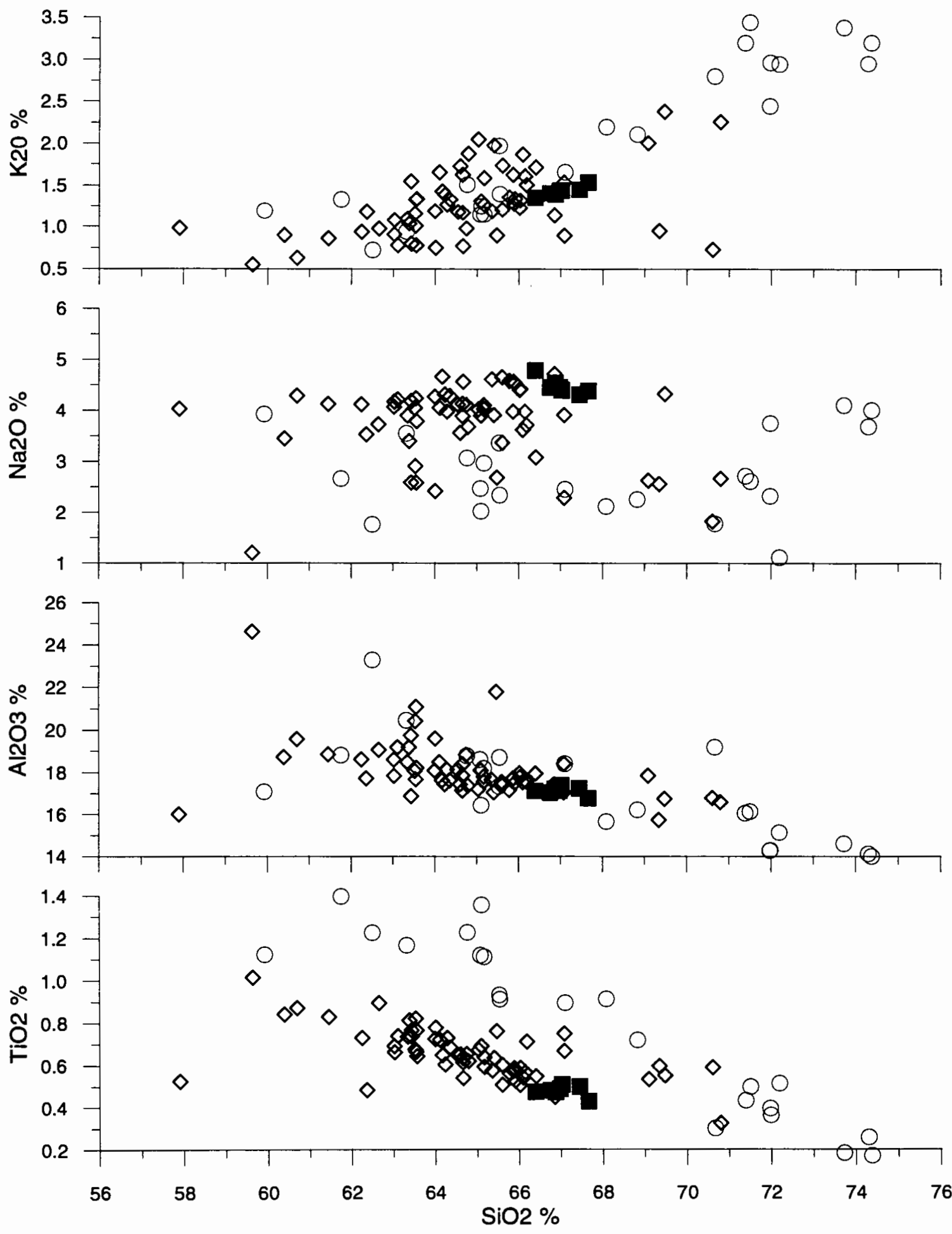

Figure 41 - Major-element Harker variation diagrams of lower Ellensburg rocks (open circles), upper Ellensburg rocks (open diamonds) and dacites from old Scab Mountain (closed squares). 
105
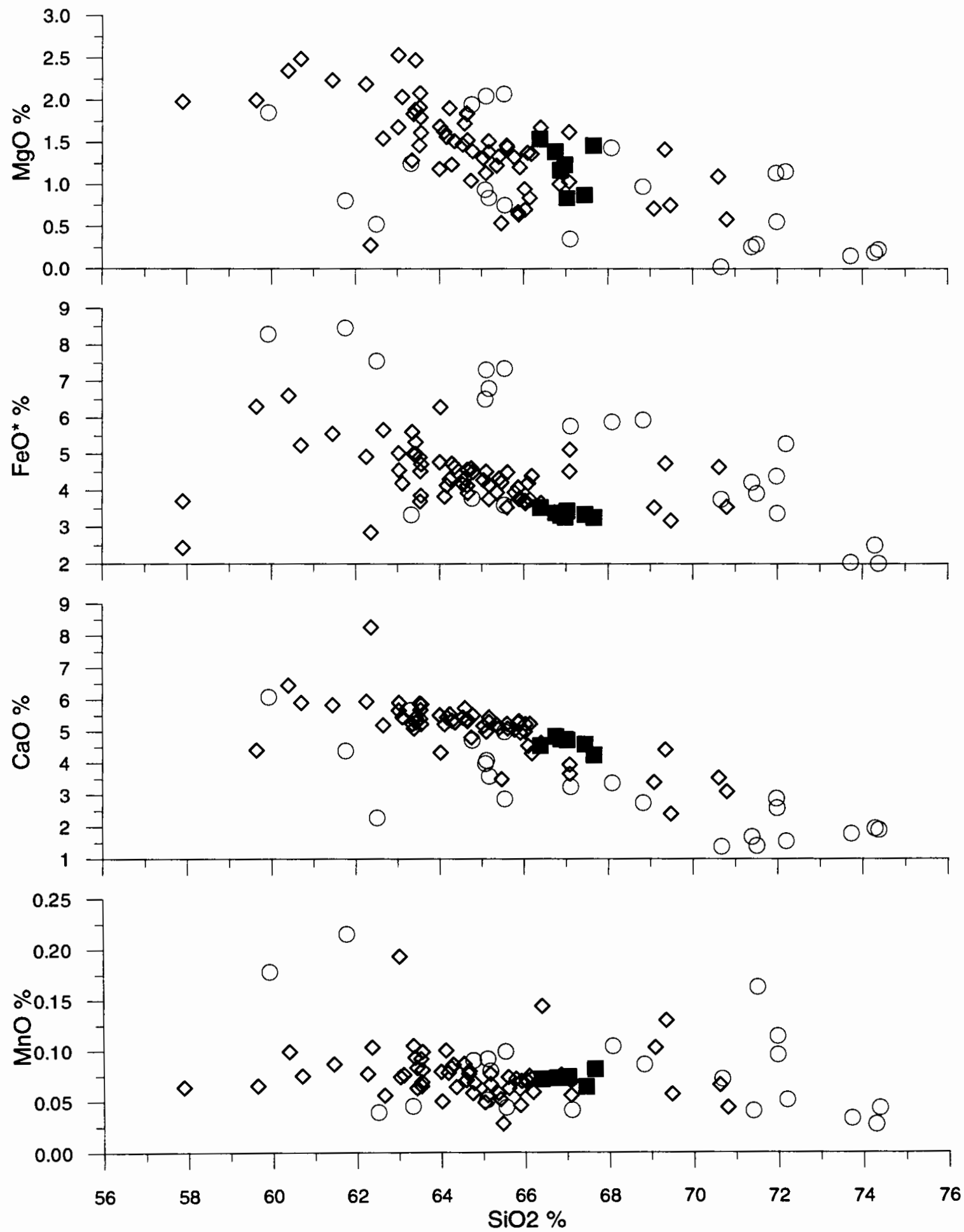

Figure 41 - continued. 


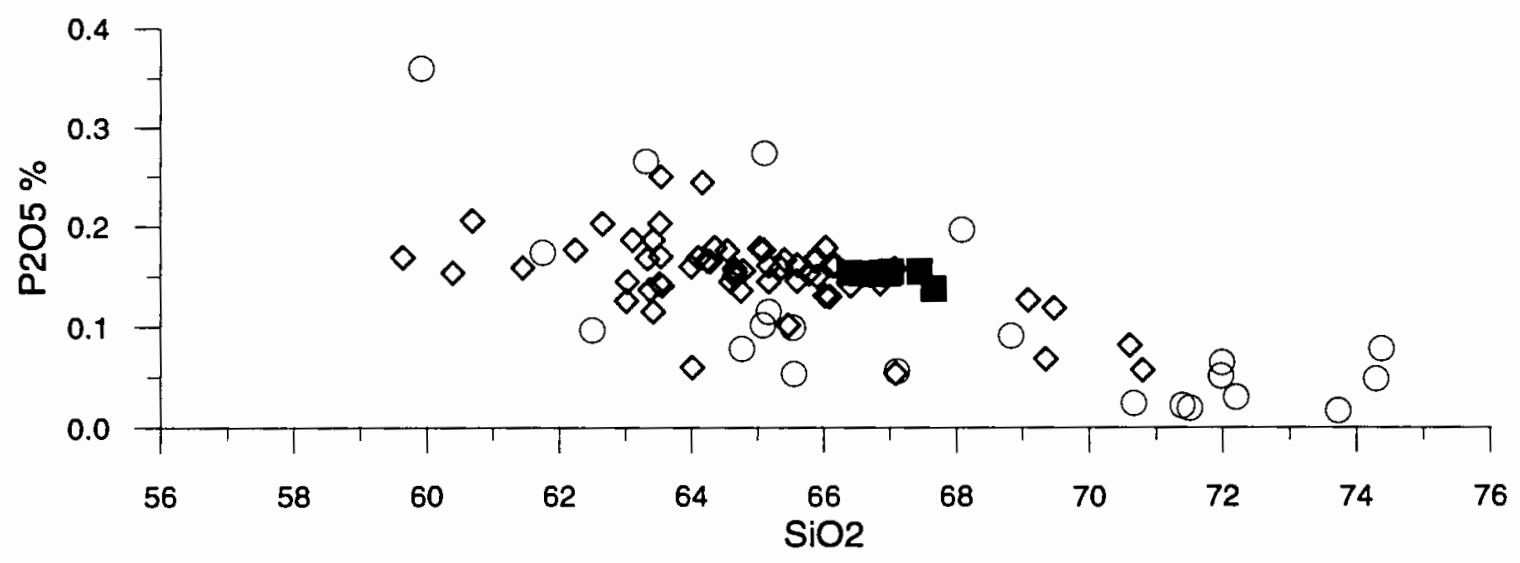

Figure 41 - continued. 
$\mathrm{K}_{2} \mathrm{O}$ and $\mathrm{Na}_{2} \mathrm{O}$ are positively correlated with respect to $\mathrm{SiO}_{2}$, whereas $\mathrm{Al}_{2} \mathrm{O}_{3}, \mathrm{TiO}_{2}, \mathrm{MgO}, \mathrm{FeO}^{*}, \mathrm{CaO}$, and $\mathrm{MnO}$ are negatively correlated with respect to $\mathrm{SiO}_{2} \cdot \mathrm{K}_{2} \mathrm{O}$ content falls within the medium-K range as defined by Peccerillo and Taylor (1976), which is typical for calc-alkaline dacitic rocks found within the High Cascades Range (McBirney, 1993; McBirney and White, 1982; Irvine and Baragar, 1971). Calc-alkaline, mediumK rocks are commonly associated with convergent plate boundaries and may have a high degree of differentiation relative to the magma source (MCBirney, 1993). In general, all major oxide concentrations fall within the typical range of Cascadian volcanic rocks as defined by McBirney (1993) with the exception of titania, which is slightly lower.

The lower Ellensburg Formation units have generally higher concentrations of $\mathrm{K}_{2} \mathrm{O}, \mathrm{TiO}_{2}$, and $\mathrm{FeO}^{*}$, and lower concentrations of $\mathrm{Na}_{2} \mathrm{O}$ and $\mathrm{CaO}$ than do the upper units, and are characterized by two general trends in the lower and upper Ellensburg distributions (Fig. 41). The lower deposits also show a much larger variance in major oxide concentration than those found stratigraphically higher. The dacite of old scab Mountain correlates well with the upper Ellensburg units, and plots within the upper silica range of the linear trend defined by the upper Ellensburg samples. 
Using stratigraphic section E (Fig. 13) as representing the typical Ellensburg stratigraphic sequence within the Nile basin, it is possible to evaluate major oxide changes progressively up section (Fig. 42). $\mathrm{SiO}_{2}$ content shows a slight increase moving upsection although it is quite variable. $\quad \mathrm{Na}_{2} \mathrm{O}$ and $\mathrm{P}_{2} \mathrm{O}_{5}$ contents also show an increase up section; whereas $\mathrm{TiO}_{2}$ shows a subtle decrease. All other major oxide concentrations are too variable to show any progressive change.

\section{TRACE ELEMENTS}

The main distinction between samples of the upper and lower Ellensburg Formation is seen in their trace element concentrations. Trace element concentrations of the lower Ellensburg deposits are typically higher in $\mathrm{Ba}, \mathrm{Rb}, \mathrm{Zr}$, Th, Ia and $\mathrm{Sm}$, and lower in $\mathrm{Ni}, \mathrm{Cr}$ and $\mathrm{Sr}$ than those of the upper Ellensburg deposits. The lower deposits also show much greater variation in their trace element concentrations than the upper deposits. The dacites of old Scab Mountain consistently plot with the upper Ellensburg distributions.

The upper Ellensburg units are typically lower with respect to most large-ion lithophile (LIL) elements (Cs, Rb, $\mathrm{Ba}$, and $\mathrm{Th}$ ) with the exception of $\mathrm{Sr}$ (Eigs. 43 and 44 ). The higher sr content is possibly due to fractional crystallization of plagioclase, since Sr readily substitutes 
(A)

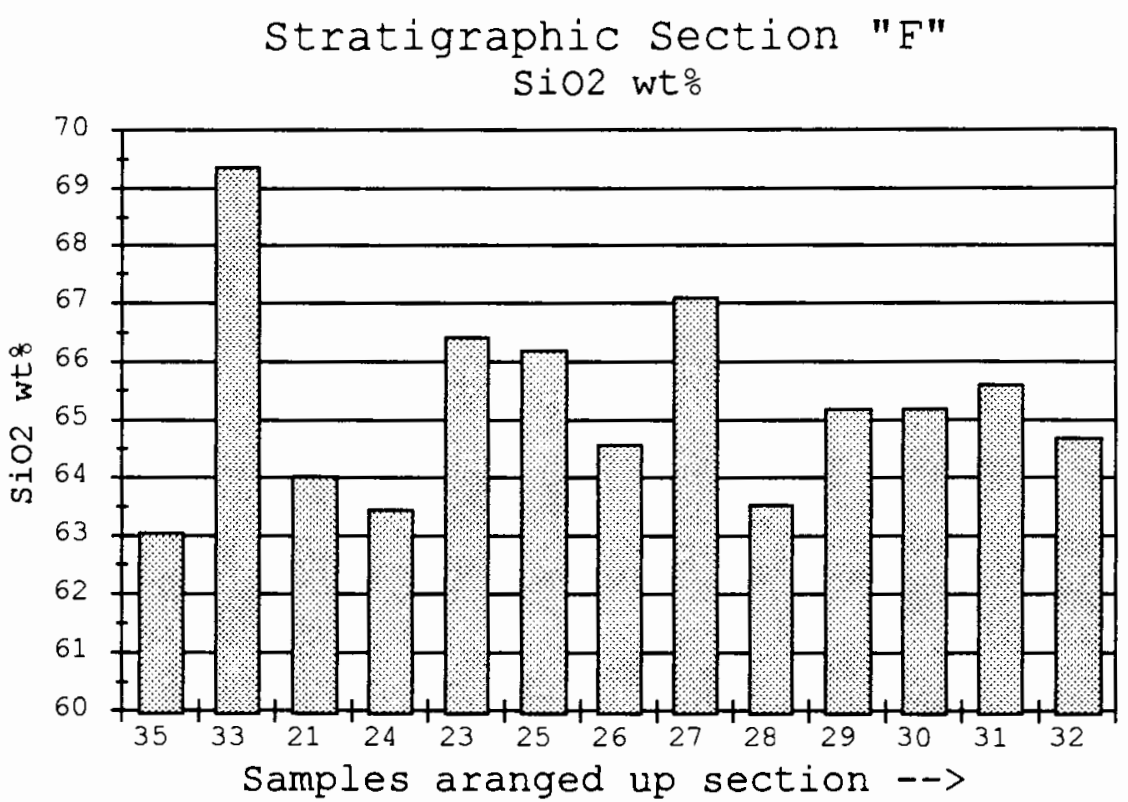

(B)

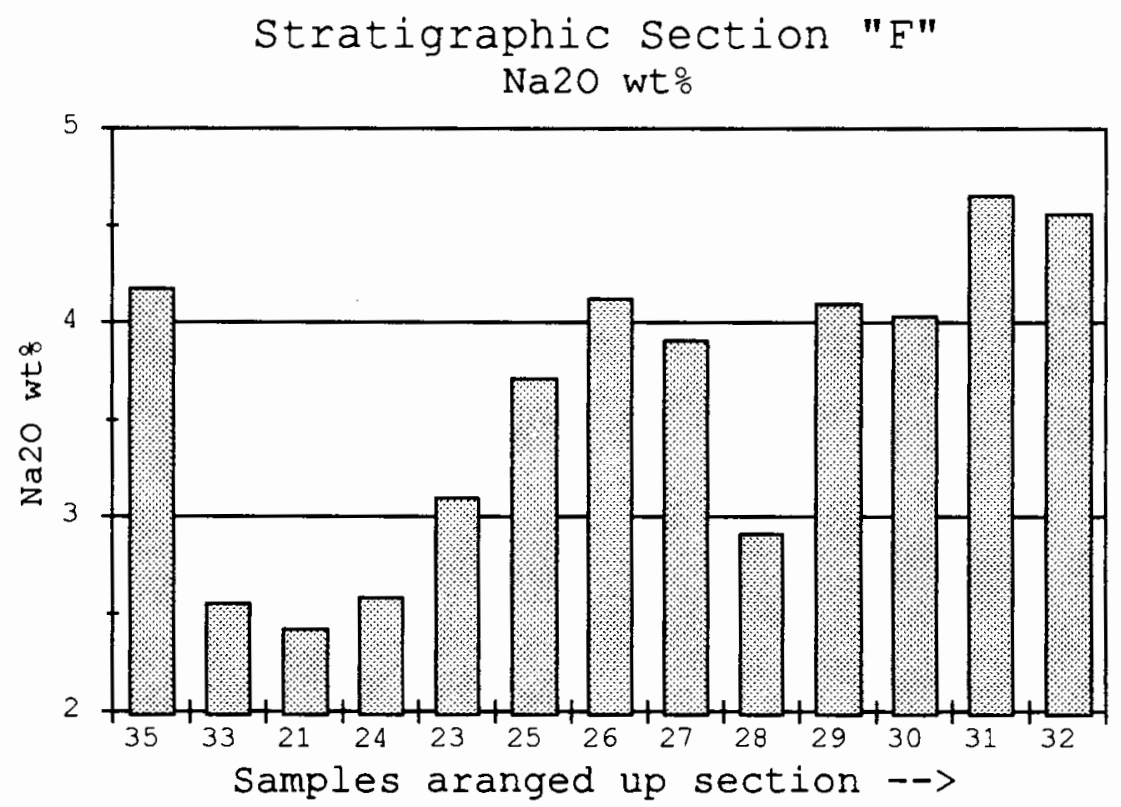

Figure $42-\mathrm{SiO}_{2}$ wtg (a), $\mathrm{Na}_{2} \mathrm{O}$ wto (b), $\mathrm{P}_{2} \mathrm{O}_{5}$ wtg (c) and $\mathrm{TiO}_{2}$ wto (d) of Ellensburg samples of stratigraphic section " $F$ " arranged progressively up section. 
(C)
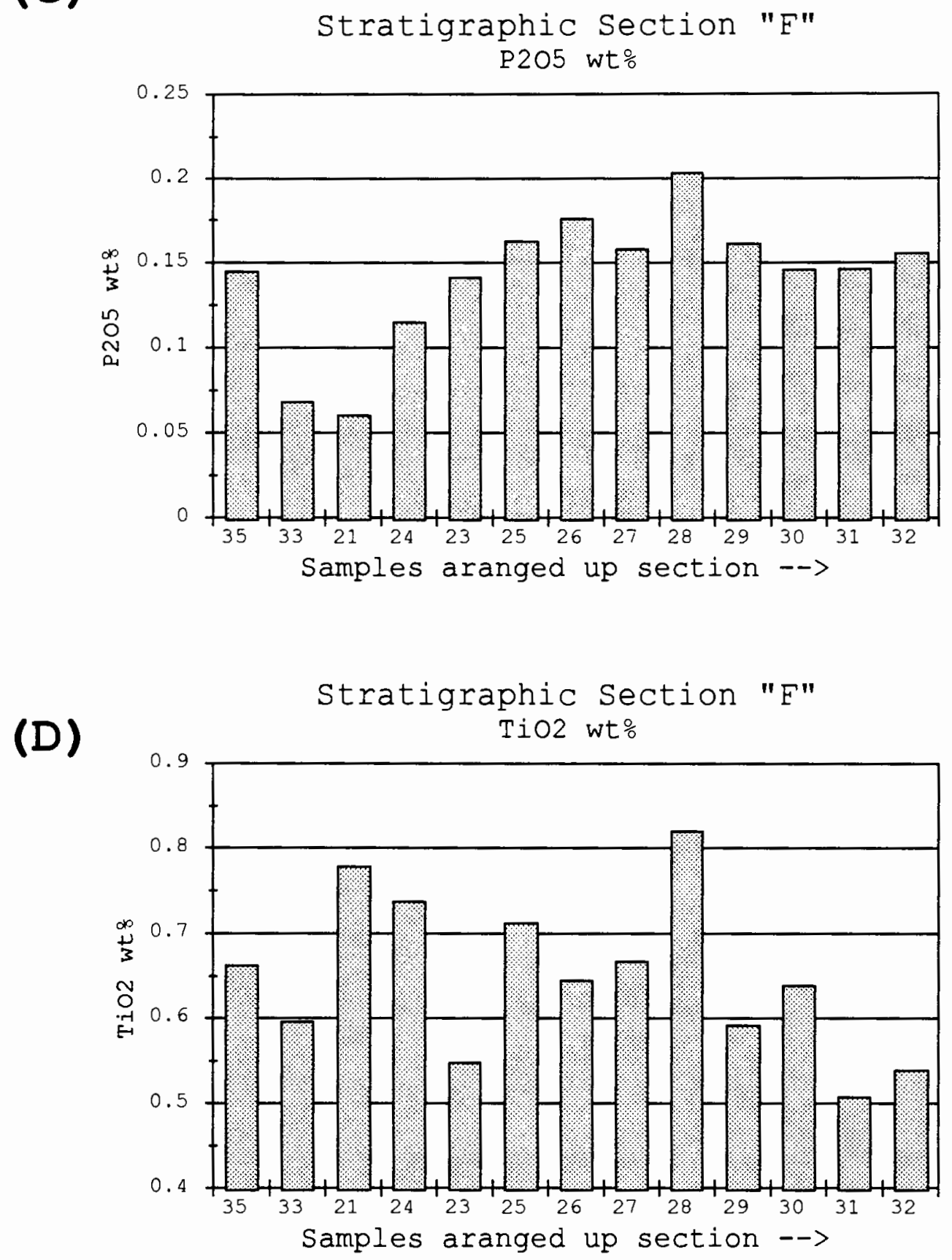

Figure 42 - Continued. 


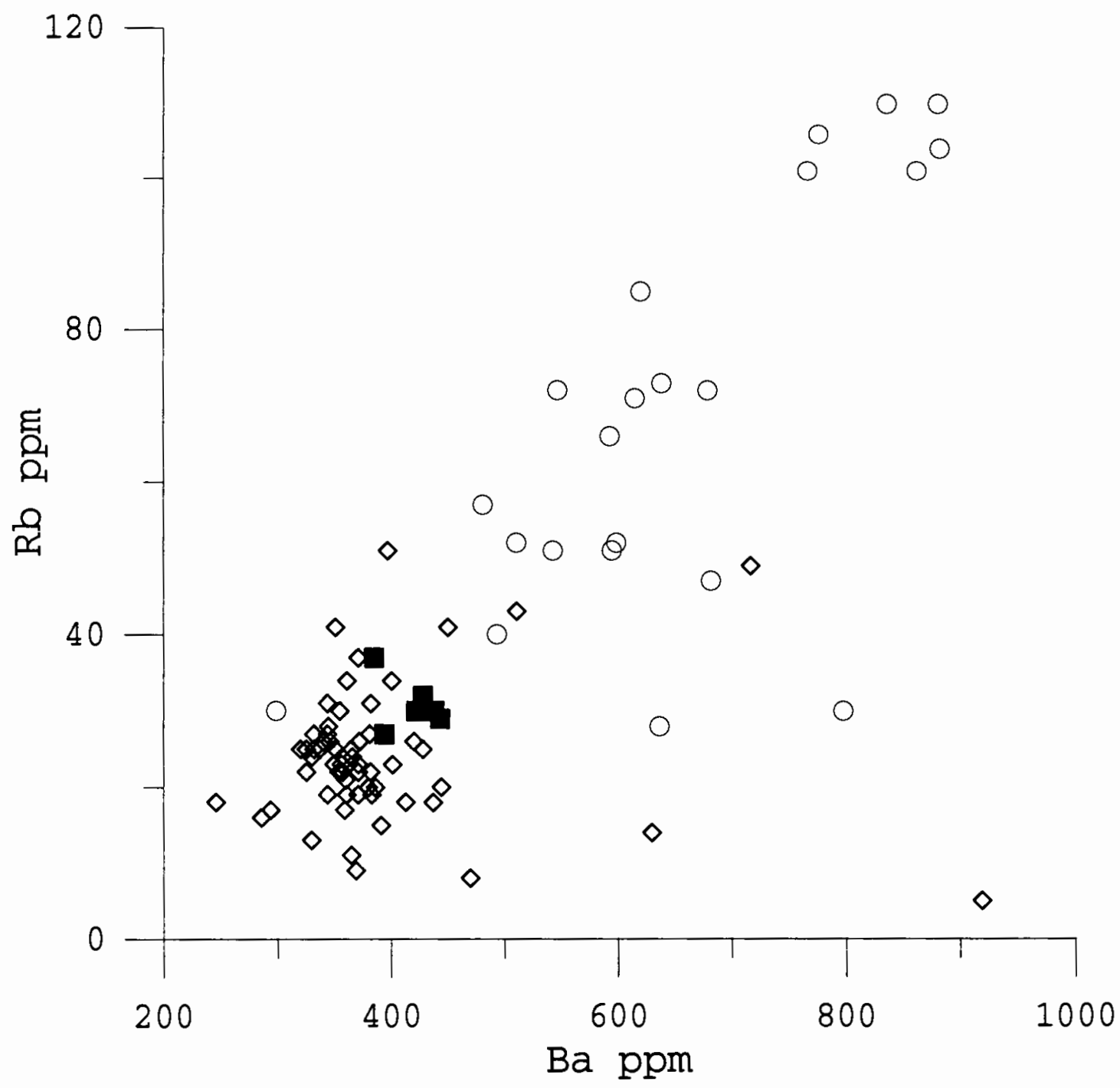

Figure 43 - $\mathrm{Rb}$ versus $\mathrm{Ba}$ plot of lower Ellensburg rocks (open circles), upper Ellensburg rocks (open diamonds) and dacites from old Scab Mountain (closed squares). 


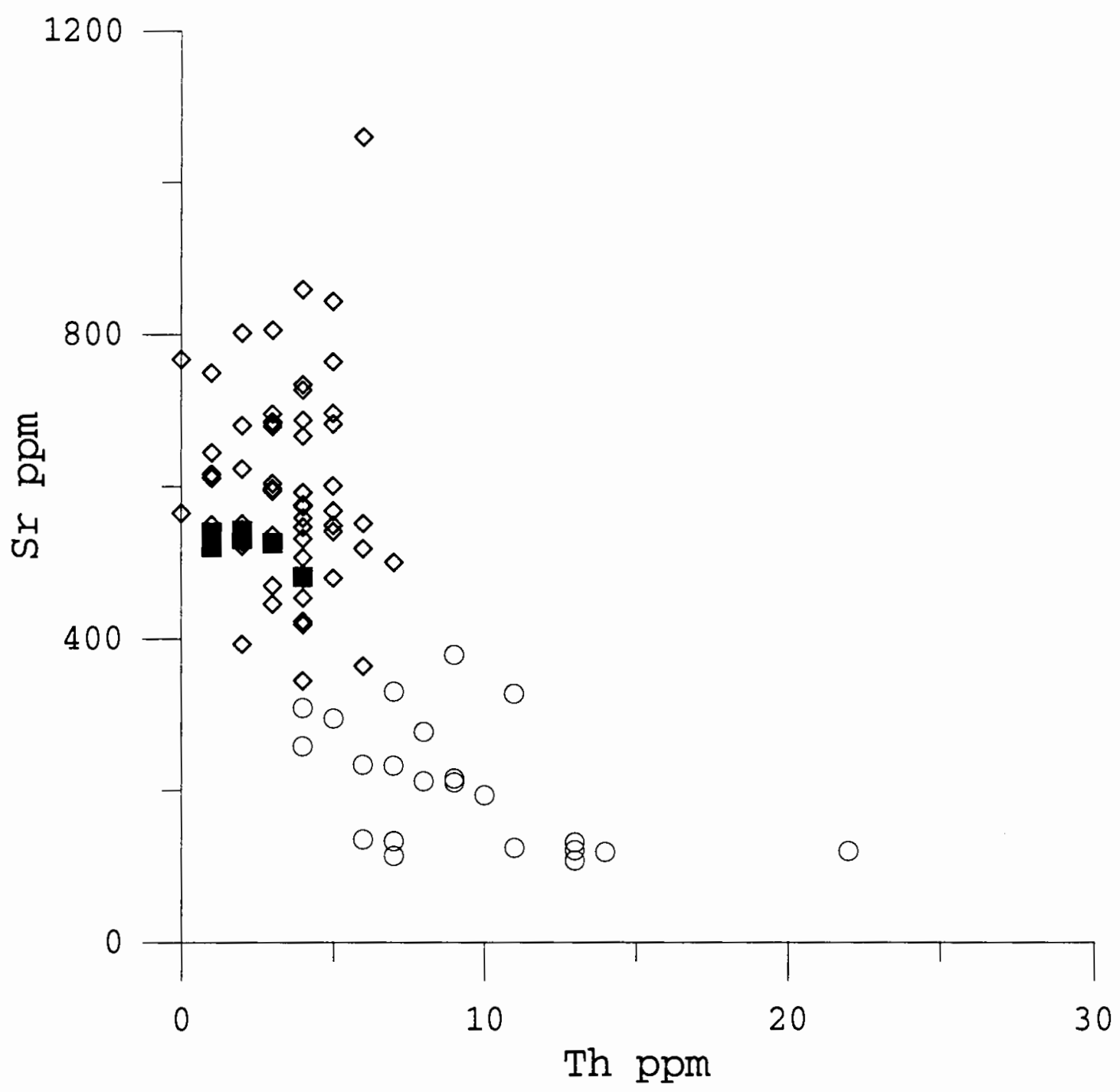

Figure 44 - Sr versus Th plot of lower Ellensburg rocks (open circles), upper Ellensburg rocks (open diamonds) and dacites from old Scab Mountain (closed squares). 
for Ca in plagioclase (Fig. 45). During initial plagioclase crystallization $\mathrm{Ca}$ is primarily taken up from the melt leaving the melt enriched in Sr. As the initial plagioclase fractionates out, subsequent plagioclase crystallization is enriched in Sr as the result of the depletion of $\mathrm{Ca}$ in the system.

The common high-field strength elements (HFSE), which include $\mathrm{Nb}, \mathrm{Ta}, \mathrm{P}, \mathrm{Y}, \mathrm{Zr}$, and $\mathrm{T} i$, also show distinct chemical differences between Ellensburg units. Figure 46 shows a plot of $\mathrm{TiO}_{2}$ versus $\mathrm{Zr}$ which is designed to show relative degrees of fractional crystallization (Pearce and Norry, 1979). The upper Ellensburg samples show a well defined decrease in $\mathrm{TI}$ concentration with relatively little change in $\mathrm{Zr}$ concentrations. Such decrease in $\mathrm{TiO}_{2}$ concentrations suggests fractional crystallization during crystallization of biotite, amphiboles, and particularly magnetite (Pearce and Norry, 1979). The dacite of old Scab Mountain plots at the base of the $\mathrm{TiO}_{2}$ trend suggesting a greater degree of fractional crystallization. The lower Ellensburg Formation plots in a disperse pattern (Fig. 46).

Figure 47 shows a log-log plot of Nb versus $\mathrm{Y}$. This plot has been used by Pearce and others (1984) to subdivide granites according to their intrusive setting (i.e. ocean ridge granites, volcanic arc granites, and within plate granites). Upper Ellensburg Formation and dacite of old Scab 


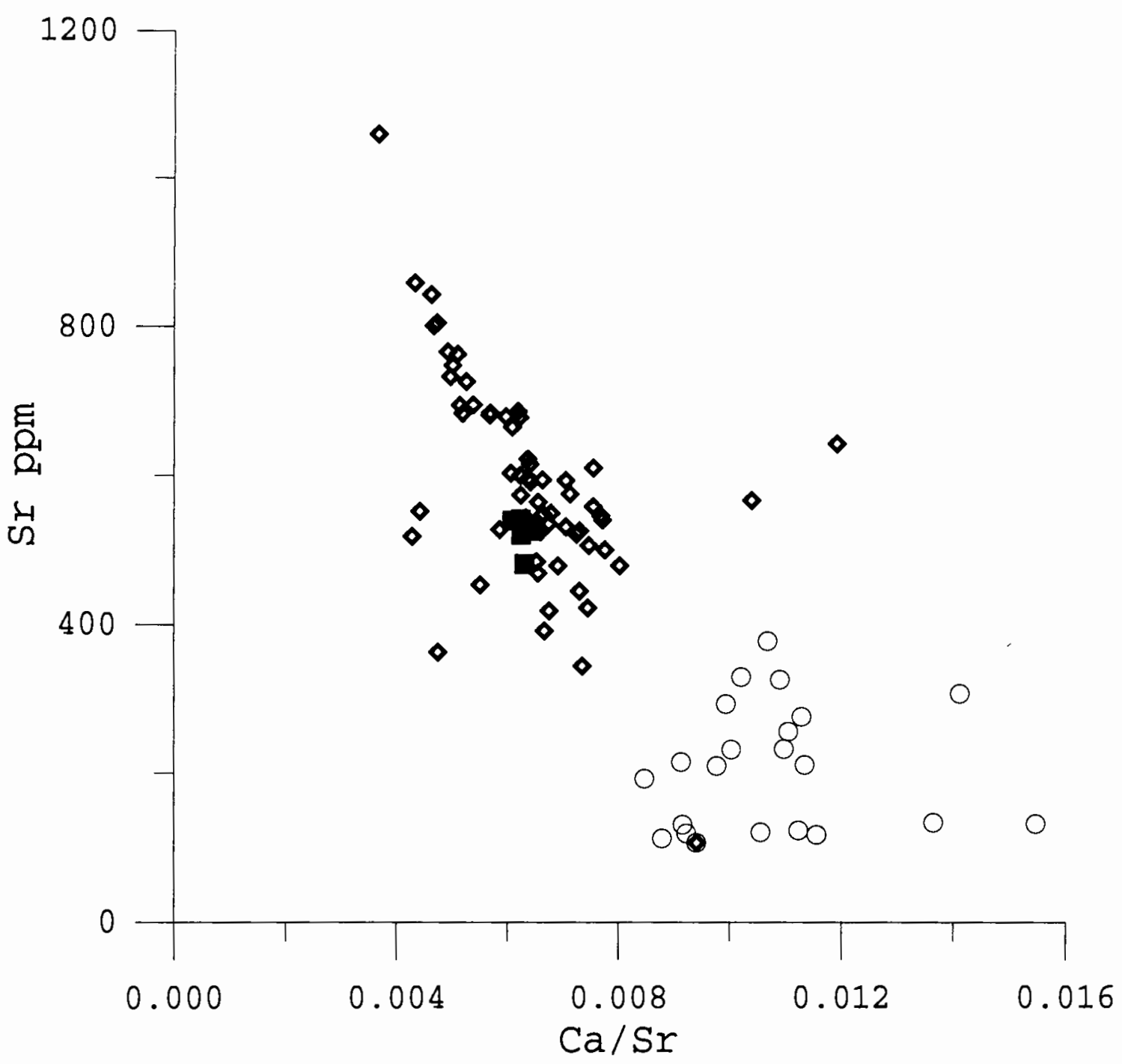

Figure 45 - Sr versus $\mathrm{Ca} / \mathrm{Sr}$ plot of lower Ellensburg rocks (open circles), upper Ellensburg rocks (open diamonds) and dacites from old Scab Mountain (closed squares). 


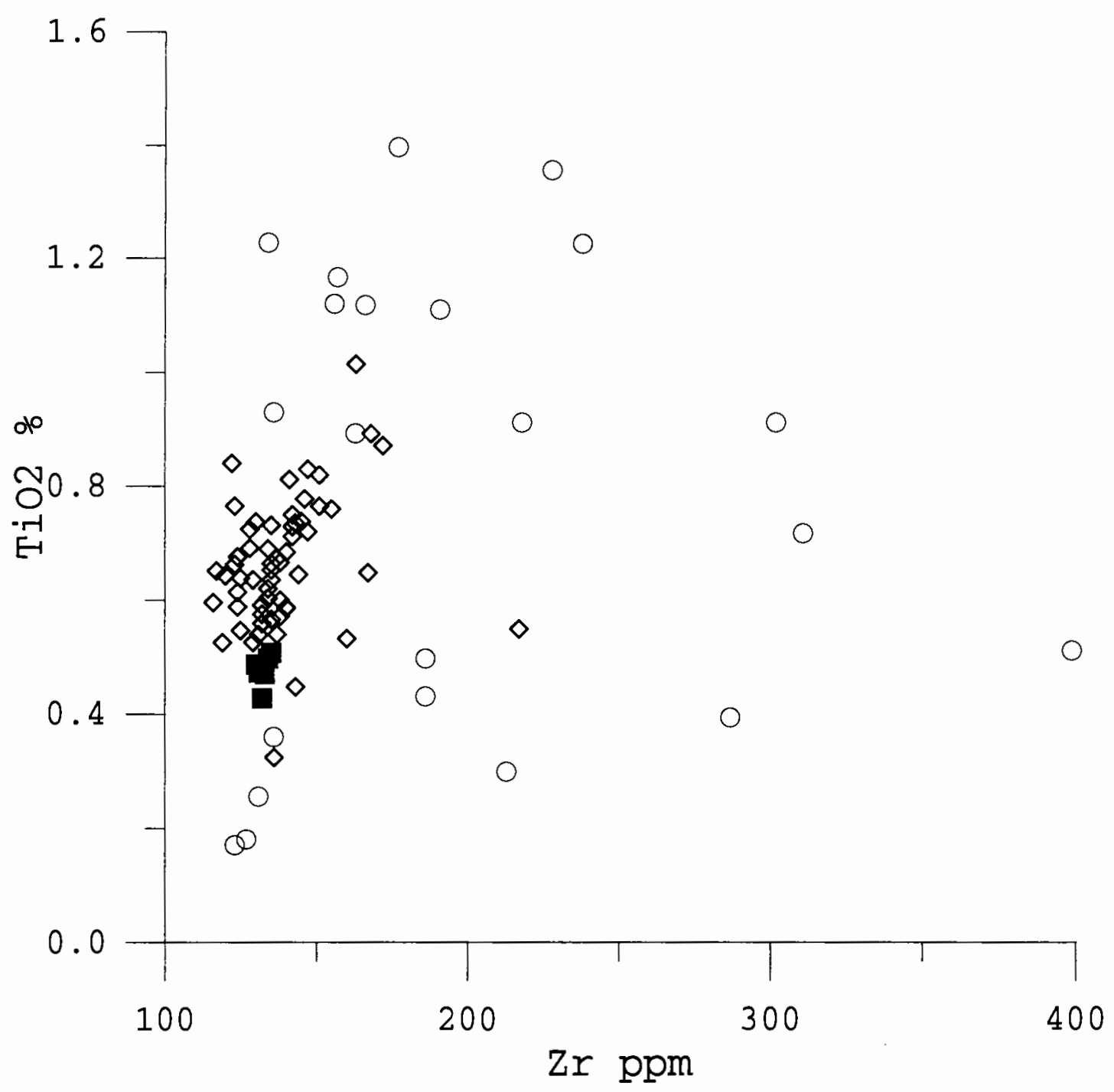

Figure 46 - TiO2 versus $\mathrm{Zr}$ plot of lower Ellensburg rocks (open circles), upper Ellensburg rocks (open diamonds) and dacites from old Scab Mountain (closed squares). 


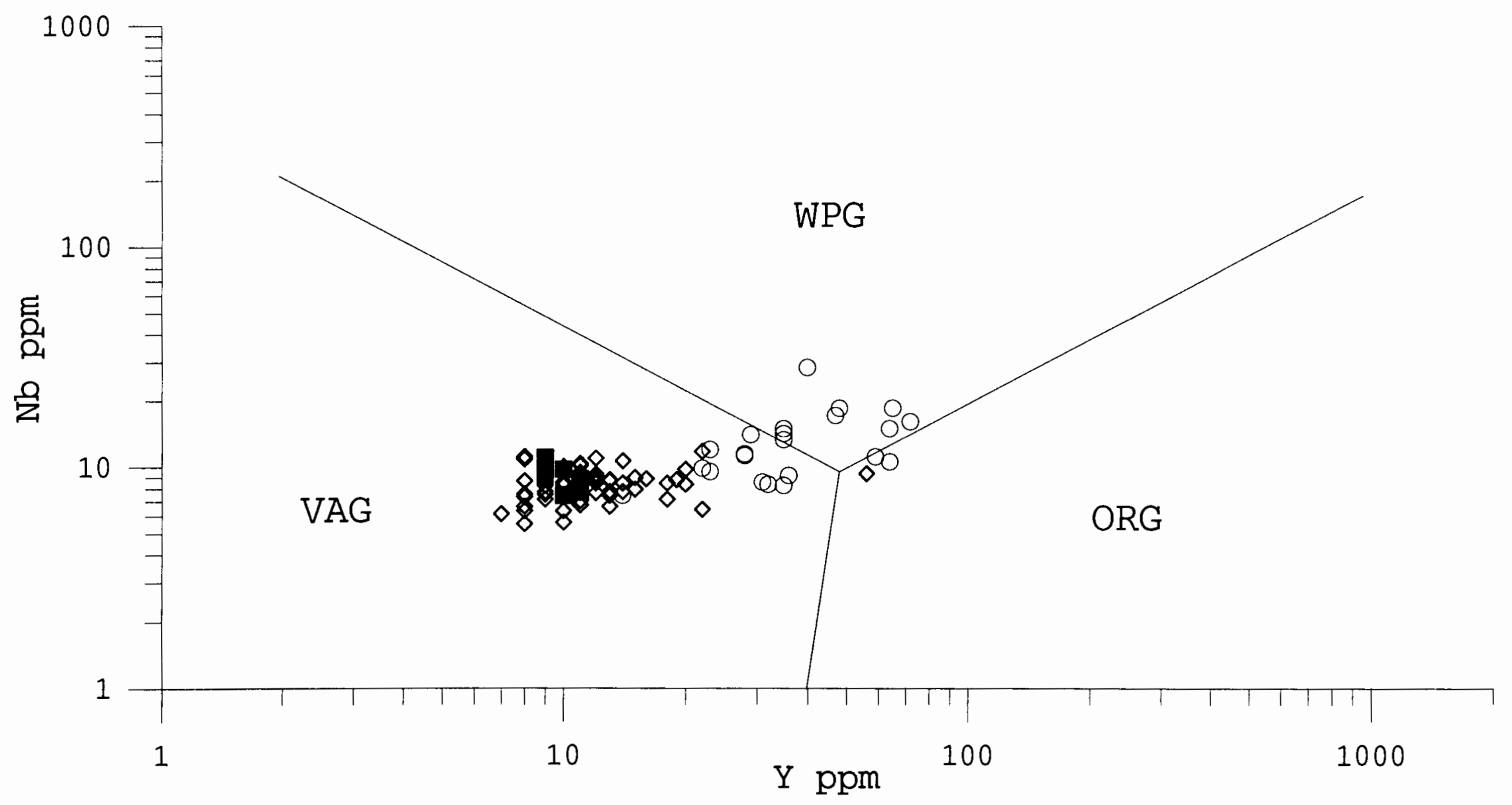

Figure 47 - Nb versus Y log-log plot of lower Ellensburg rocks (open circles), upper Ellensburg rocks (open diamonds) and dacites from old Scab Mountain (closed squares). (VAG) Volcanic Arc Granites, (WPG) Within Plate Granites, (ORG) Ocean Ridge Granites. (Plot after Pearce and others, 1984). 
Mountain plot within the "volcanic arc granite" range, whereas, the lower Ellensburg units contain higher concentrations of $\mathrm{Y}$ and $\mathrm{Nb}$ and approach the "within plate granite" range. Furthermore, the relatively higher concentration of $\mathrm{Rb}, \mathrm{Ba}, \mathrm{Th}$, and $\mathrm{K}$, as discussed above, in the lower Ellensburg samples are commonly associated with withinplate or crustal component (Thorpe and others, 1984; Pearce and others, 1984).

The concentrations of $\mathrm{Ni}$ and $\mathrm{Cr}$ are typically lower in the lower Ellensburg samples in comparison with the upper Ellensburg samples (Fig. 48). The dacite of Old Scab Mountain makes up an intermediate range, plotting between upper and lower Ellensburg clusters. $\mathrm{Ni}$ and $\mathrm{Cr}$ are considered compatible elements and are typically enriched in more mafic minerals, such as magnetite.

Chondrite-normalized spider diagrams of the Ellensburg and related dacitic intrusive samples are shown in Figures 49 and 50 (after Thompson and others, 1982). Figure 49 shows the compositional range of the lower Ellensburg samples, the upper Ellensburg samples, and two dacite samples from old Scab Mountain. The spider diagram patterns of the upper Ellensburg samples and the dacite of Old Scab Mountain are relatively consistent; whereas, the spider diagram patterns of the lower Ellensburg samples tend to be high with respect to $\mathrm{Ba}, \mathrm{Rb}, \mathrm{Th}$, Ta, La, Sm, $Y$, and $Y b$, and show a negative anomaly with 


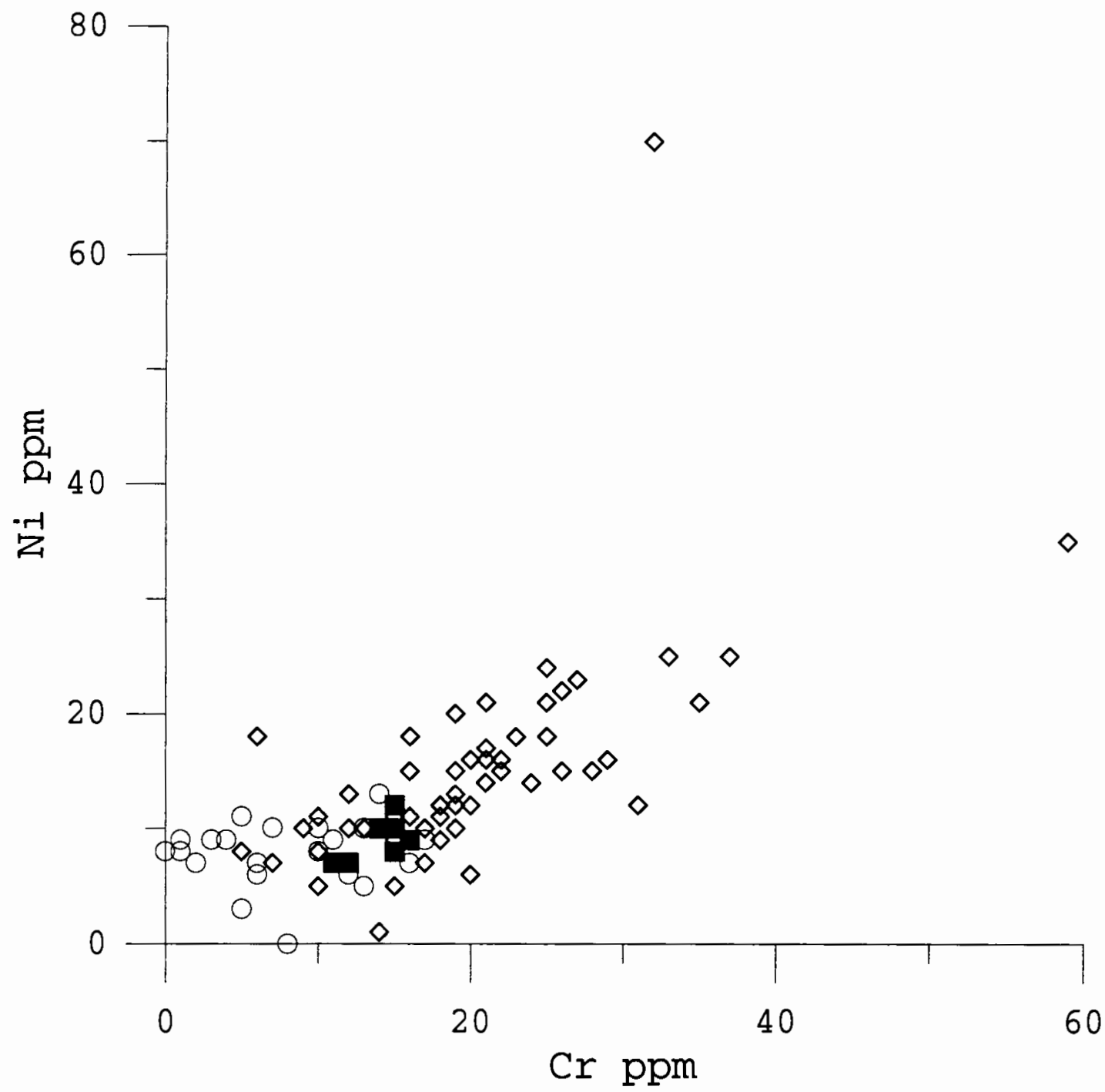

Figure 48 - $\mathrm{Ni}$ versus $\mathrm{Cr}$ plot of lower Ellensburg rocks (open circles), upper Ellensburg rocks (open diamonds) and dacites from old Scab Mountain (closed squares). 


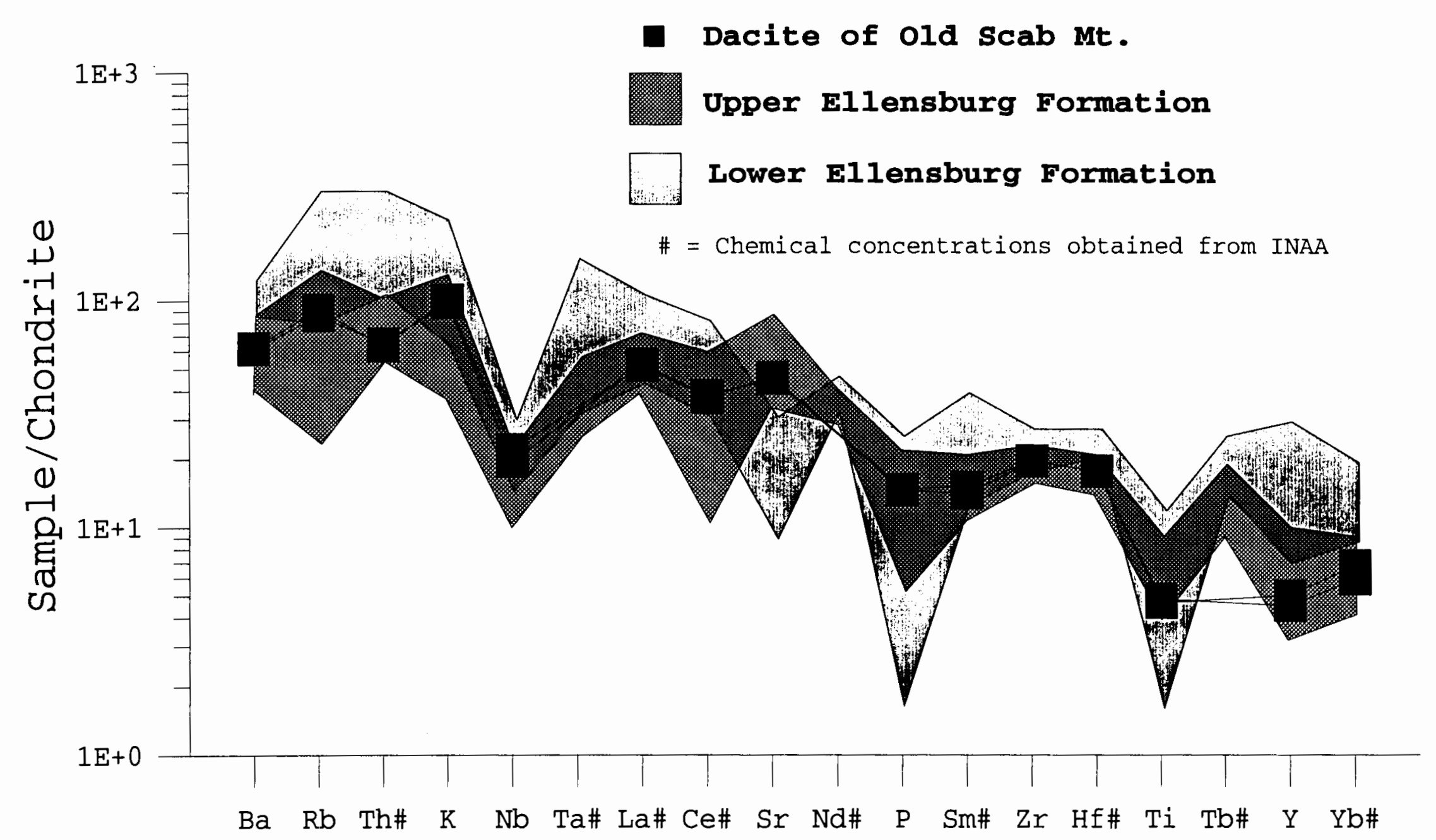

Figure 49 - Spider diagram plot showing the compositional range of lower Ellensburg rocks, upper Ellensburg rocks, and two dacite samples from old Scab Mountain (after Thompson and others, 1982). $\vec{\sigma}$ 


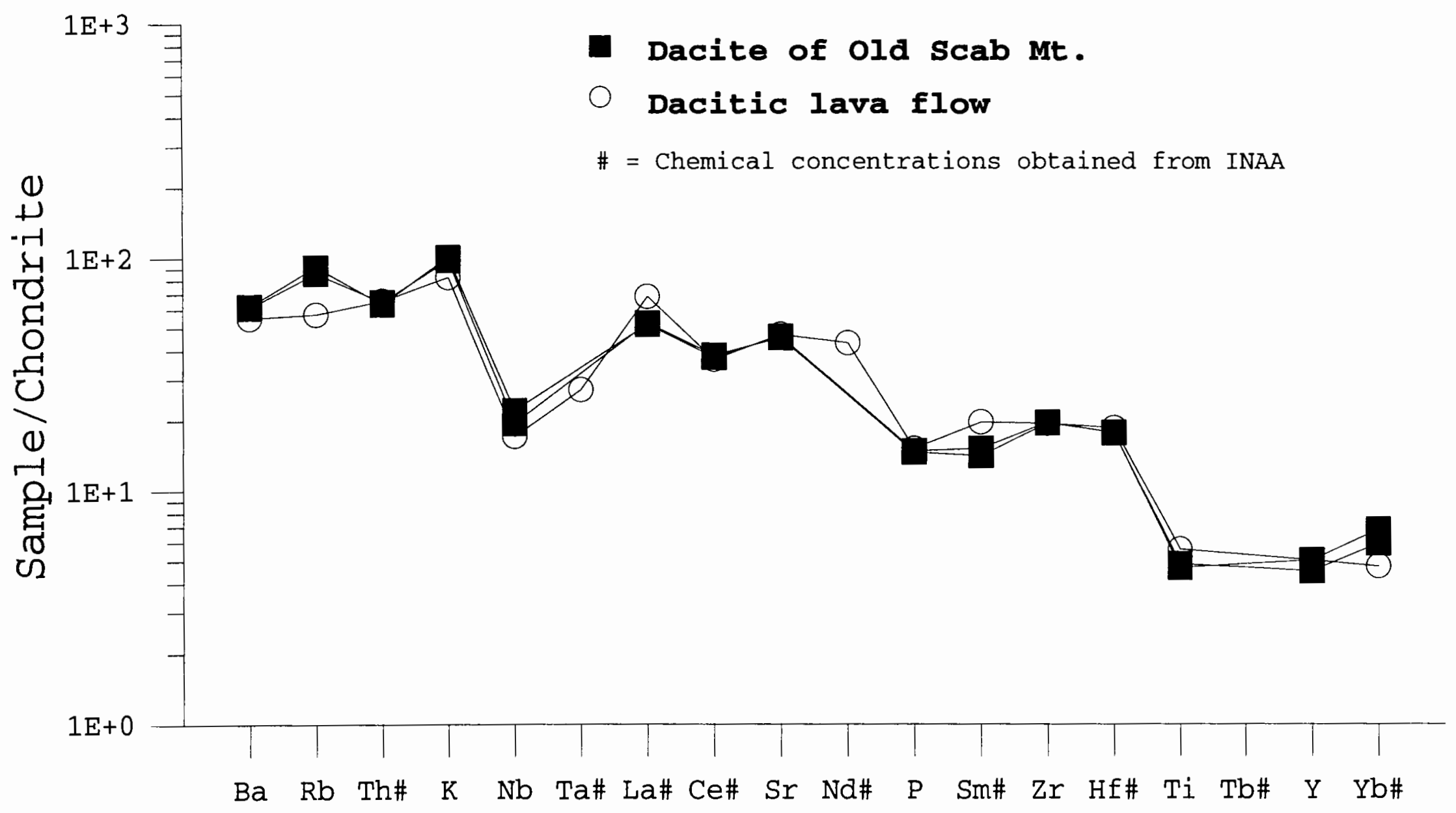

Figure 50 - Spider diagram plot of dacitic lava flow and two dacite samples from old Scab Mountain (after Thompson and others, 1982). 
respect to $\mathrm{sr}$. Figure 50 shows the spider diagram patterns of two dacite samples from old Scab Mountain and the dacitic lava flow located approximately $14 \mathrm{~km}$ east-southeast of old Scab Mountain. All three spider diagram patterns are similar and may suggest that the dacite from old scab Mountain and the lava flow originated from a similar magma source.

Chondrite-normalized rare-earth-element (REE) spider diagram for the Ellensburg and Old Scab Mountain samples are shown in Figure 51 (chondrite values after sun and McDonough, 1989). All samples are enriched with respect to the light-REE indicated by a negative slope. The lower Ellensburg samples are generally higher in all REE with the exception of Eu, where the splder diagram patterns show a negative Eu anomaly. Negative Sr and Eu anomalies in spider diagram patterns, as seen in the lower Ellensburg Formation (Figs. 50 and 51), are commonly associated with extensive plagioclase fractionation. Positive Sr and Eu anomalies in the upper Ellensburg and Old Scab Mountain spider diagram patterns suggest that plagioclase was not stable in the source and/or did not extensively fractionate during magma ascent (Defant and Drummond, 1993).

STATISTICS

Statistical application can be difficult to interpret when attempting to correlate rock units. Although statistics 


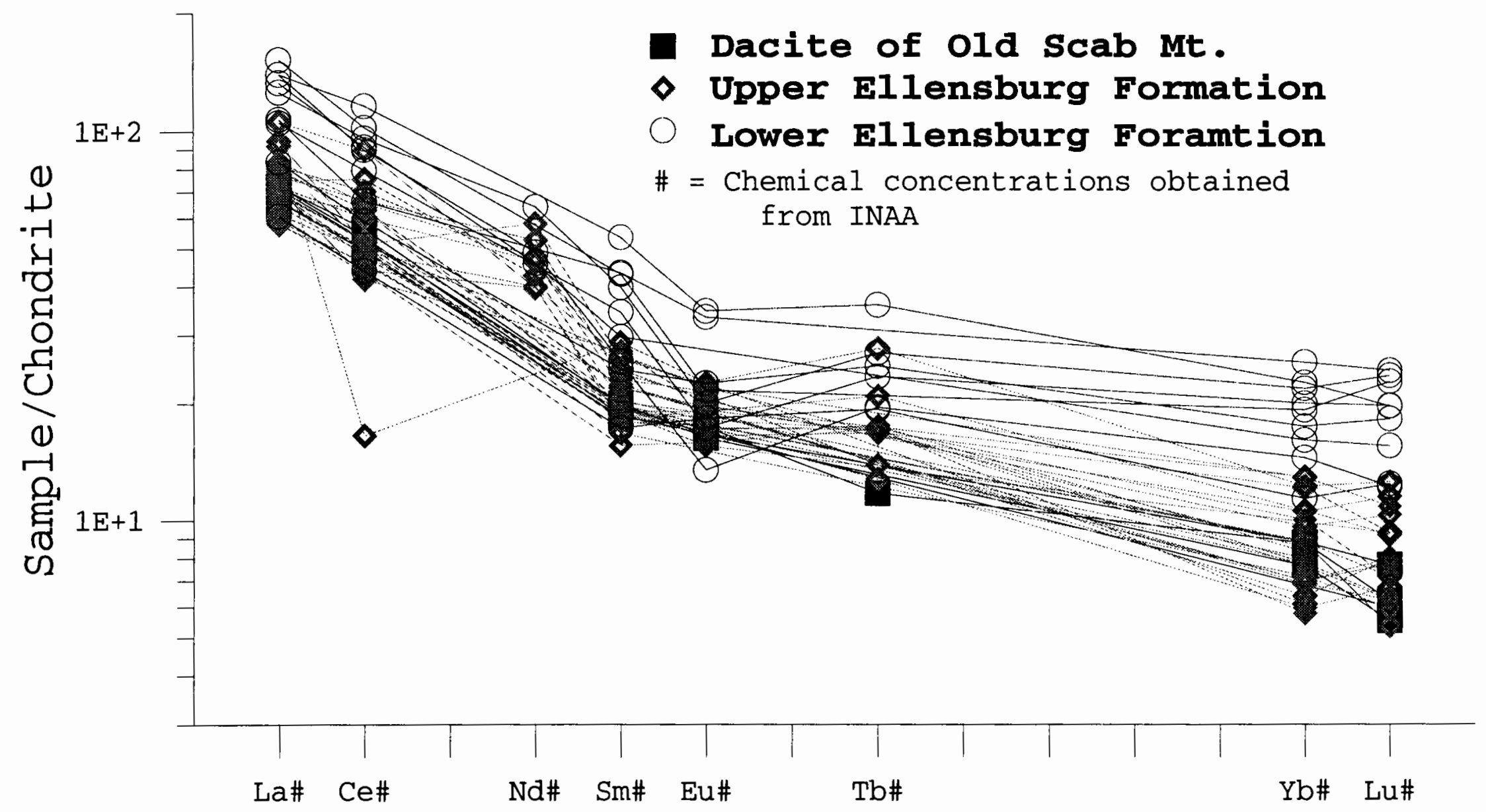

Figure 51 - Spider diagram plot showing chondrite-normalized rare earth element composition of lower Ellensburg rocks, upper Ellensburg rocks, and dacite samples from old Scab Mountain (after Sun and McDonough, 1989). 
plays an important role in geology when determining quantitative differences between rock units, statistical results can be inconclusive when attempting to show similarities. Generally two kinds of conclusions can be made when statistically comparing two sets of geochemical data: (1) that the two sets are statistically different, or (2) that it cannot be shown that the two sets are statistically different. The second conclusion can not be interpreted as a positive correlation; instead, it can only be interpreted as a lack of statistical evidence to prove no correlation. This distinction is important when interpreting the results of the following discussion.

Using XRF data for all analyzed samples of Ellensburg and intrusive dacite materials, correlation coefficients have been calculated for all paired combinations. These correlation coefficients were tested for significance using the T-test with 25 degrees of freedom and a significance level of $5 \%$. The resulting tests showed a positive correlation for all paired combinations. This result was not unexpected due to the multivariate aspects of geochemical data. However, qualitative comparisons can be made using the correlation coefficients obtained.

Eigure 52 shows the correlation coefficients of all Ellensburg and old Scab Mountain samples compared with one dacite sample of Old Scab Mountain (\#94080) using XRF data. 


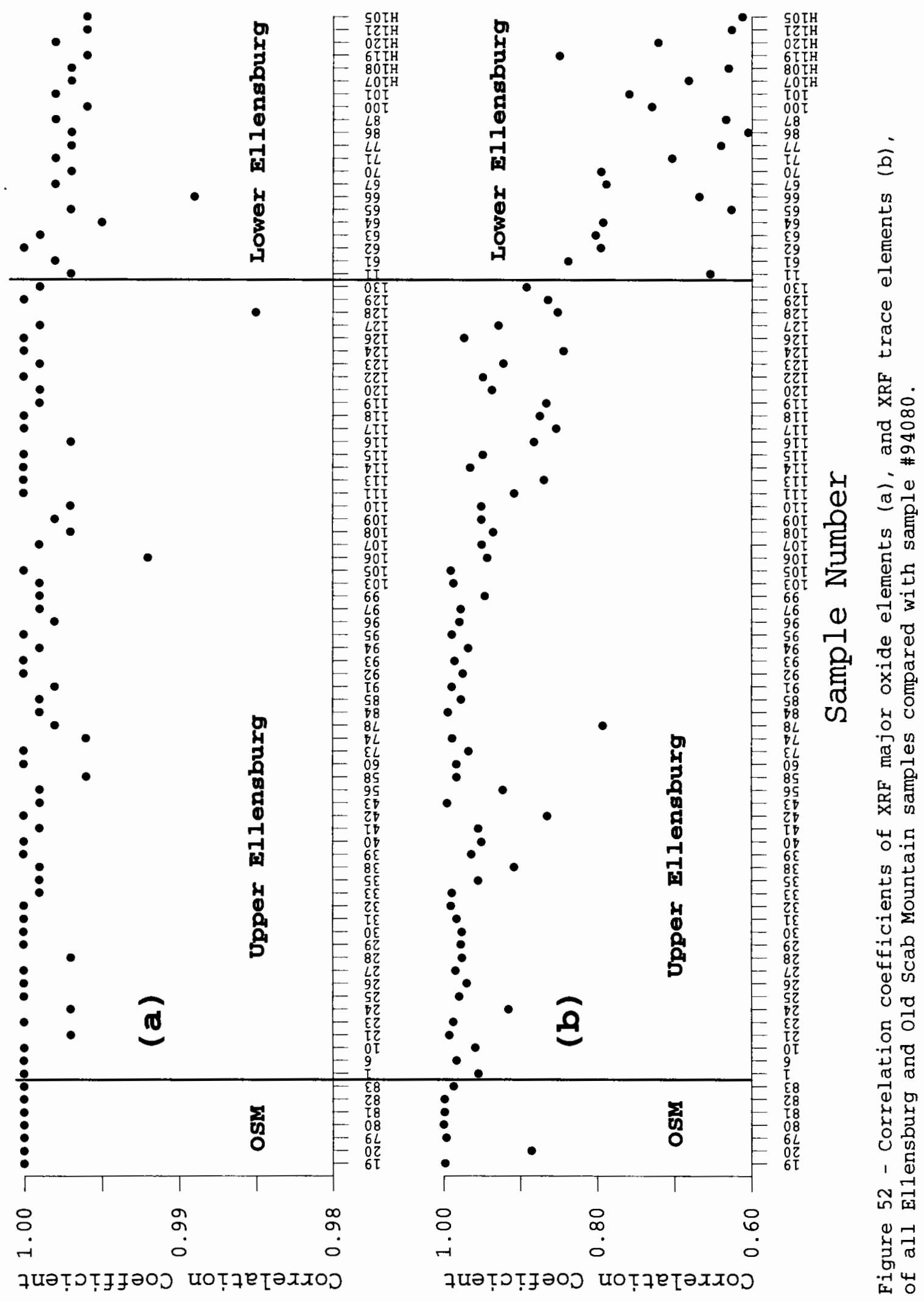


Sample \#94080 was selected because it showed the least discoloration and degree of alteration of all the old scab Mountain dacite samples. Figure $52 \mathrm{a}$ shows the correlation coefficients using major oxide data, and Figure $52 \mathrm{~b}$ shows the correlation coefficients using trace element data. These plots demonstrate that sample \#94080 from Old Scab Mountain resembles the upper Ellensburg rocks more than these resemble the lower Ellensburg rocks, and that most of the variation is in the trace element concentrations.

Sample \#94020, which is a dacite intrusive rock collected near the south flank of old Scab Mountain (Plate 1), shows a relatively poor correlation when compared with the other intrusive dacite samples (Fig. 52b). This poor correlation may indicate that Sample \#94020 may not be associated with the main intrusive body which forms old scab Mountain. Instead, it may be associated with the younger dacitic intrusion found to the south of old Scab Mountain.

A more accurate method to distinguishing between multivariate geochemical data is by the use of Q-mode factor analysis (Davis, 1986). Similarity coefficients (Pearson Product Moment Correlation Coefficient) were calculated using the trace element values obtained from XRF analysis (Appendix A). Eigenvalues and eigenvectors were then calculated from the resulting square matrix of similarity coefficients. These eigenvalues and eigenvectors represent the variance within the sample population in multidimensional space. Factors were 
then calculated from the eigenvectors by multiplying each vector by the square root of its corresponding eigenvalue. Appendix D gives the first three eigenvalues, eigenvectors, and their respective factors, which represents $94.86 \%$ of the total variance. When the second and third factors are plotted together two distribution trends develop (Fig. 53). The first factor is not plotted because it contains most of the variance and would overpower the second and third factors in a XY plot. The positively sloping trend represents upper Ellensburg and old Scab Mountain rocks. The negatively sloping trend represents lower Ellensburg rocks. These distributions graphically portray the chemical differences between upper and lower Ellensburg Eormation within the Nile basin. The plot also demonstrates that dacite of old Scab Mountain shows a greater chemical similarity to the upper Ellensburg Formation. 


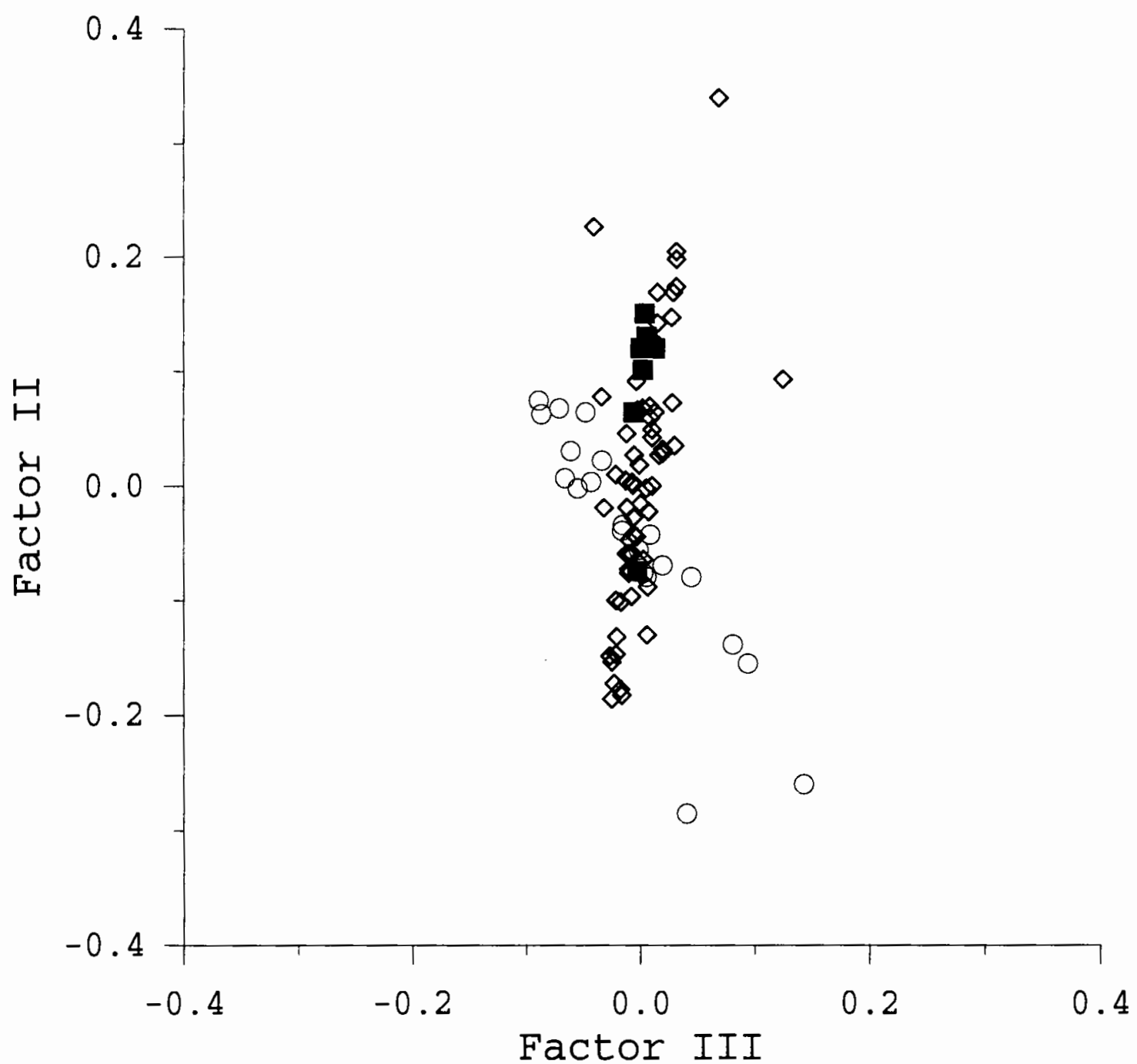

Figure 53 - Factor II vs. Factor III of lower Ellensburg rocks (open circles), upper Ellensburg rocks (open diamonds), and dacites from old Scab Mountain (closed squares). Factors derived from $Q$-mode factor analysis. 


\title{
DISCUSSION
}

\author{
CORRELATION
}

Correlation of the Ellensburg Formation to Old Scab Mountain or other possible volcanic centers can be accomplished in at least three ways: (1) stratigraphic correlation: by tracing volcanic deposits from their distal to proximal facies a volcanic source area can be determined, (2) age correlation: volcanic centers that were active during the time of deposition of the Ellensburg Formation may have contributed material to that formation, and (3) chemical correlation: volcanic rocks of similar chemical compositions suggest a similar magmatic source.

\section{Stratigraphic Correlation}

Smith and others (1988) and Smith (1988a) first suggested that a possible volcanic source for the bulk of the Ellensburg Formation was located within 15 to $20 \mathrm{~km}$ west of the Nile basin. This determination was based on the proximal nature of the deposits in the basin as well as the rapid change in clast size and bedding thickness from the mouth of Rattlesnake Creek west to Nile Creek. 
Pyroclastic flow deposits within the Ellensburg Formation are largely confined to the Nile basin (Smith, 1988a). Their average thickness ranges from 3 to $5 \mathrm{~m}$, with maximum thickness up to $40 \mathrm{~m}$, and contain between 40 to 608 in volume of open-textured dacitic clasts. Moderately thick pyroclastic deposits, between 5 to $15 \mathrm{~m}$ thick, commonly contain pumice fragments and a high percentage of opentextured dacitic clasts. Block-and-ash flows have also been identified and are normally associated with dome collapse rather than collapse of an eruptive column. Pyroclastic flows with a high percentage of dense clasts are generally less mobile and commonly travel no farther than cold-rock avalanches (Carey, 1991). Their volumes are typically small, less than $1 \mathrm{~km}^{3}$, and fill erosional valleys where their thickness can be variable (Fisher and Schmincke, 1984; Cas and Wright, 1987).

The total length of pyroclastic flows are primarily dependent on topographic controls. Aspect ratios (thickness to length, $\mathrm{T} / \mathrm{L}$ ) for pyroclastic flows range from $1 / 400$ to as low as $1 / 100,000$ (Carey, 1991). High-aspect ratios (1/400) are predominant in areas with prominent topography where flows tend to fill stream valleys and other local depressions. A predominance of conglomeratic sediments along with the narrow lateral extent of stratigraphic units found within the Nile basin suggests high topographic relief and thus would also 
suggest a high-aspect ratio for pyroclastic flows. Using an aspect ratio of $1 / 400$, the resultant average flow length within the Nile basin would be 1.2 to $2.0 \mathrm{~km}$ (assuming an average thickness of 3 to 5 meters).

Massive lahar deposits are also indicative of proximal facies. Although lahar flows can travel $50 \mathrm{~km}$ or more, medial deposits become finer grained, thinner and laminar, whereas, deposits within the Nile basin are massive, reaching thickness up to 30 to $40 \mathrm{~m}$ thick, and are poorly sorted with clasts up to $4 \mathrm{~m}$ in diameter. Even more massive debris avalanche deposits, containing up to 90 percent clasts, occur south of orr Creek. Such deposits are characteristic of proximal facies and generally grade into laharic and hyperconcentrated flow deposits farther from the flank of the volcano. Blockand-ash flows are also common initiators of laharic deposits and are often difficult to distinguish from laharic deposits. The dacitic lava flow sampled north of Rattlesnake Creek, $14 \mathrm{~km}$ southeast of old Scab Mountain, is possibly the best example of the proximal nature of the Nile basin deposits. The flow is highly porphyritic and reveals a blocky surface structure indicative of high viscosity dacitic flows. Dacitic lava flows are commonly vitreous and have an average grain size of less than $0.1 \mathrm{~mm}$. The flow within the Nile basin has an average phenocryst size greater than $0.1 \mathrm{~mm}$ which increases the overall viscosity. Dacitic lava flows are 
usually small in volume and have an average length of approximately $1.2 \mathrm{~km}$, although flows have been known to travel for distances up to $25 \mathrm{~km}$ (Cas and Wright, 1987; Walker, 1973). More commonly, however, such lavas form domes constructed at the vent and may even form spectacular spires to tens of meters in height. The final lengths of the flows are dependent on the initial viscosity of the lava, the total volume of the lava extruded, the rate of effusion, the slope of the underlying surface, and the topography (Walker, 1973).

Age Correlation

Ages of rocks within the Nile basin place the upper Ellensburg Formation between $11.28 \pm 0.37$ to $7.0 \pm 1.0 \mathrm{Ma}$ (Smith and others, 1989). No age determinations are available for the dacite of old Scab Mountain; however, one age date of $8.79 \pm 0.20 \mathrm{Ma}$ has been determined for a dacitic sill extending in a westward direction from old Scab Mountain (Smith and others, 1989). This date falls within the age range of the upper Ellensburg Formation suggesting that old Scab Mountain is a possible source for Ellensburg deposits Although Old Scab Mountain has not yet been dated, crosscutting relationships with adjacent rock units suggests an age younger than the Grande Ronde Basalt. Figure 54 shows a cross section extending from old scab Mountain east- 


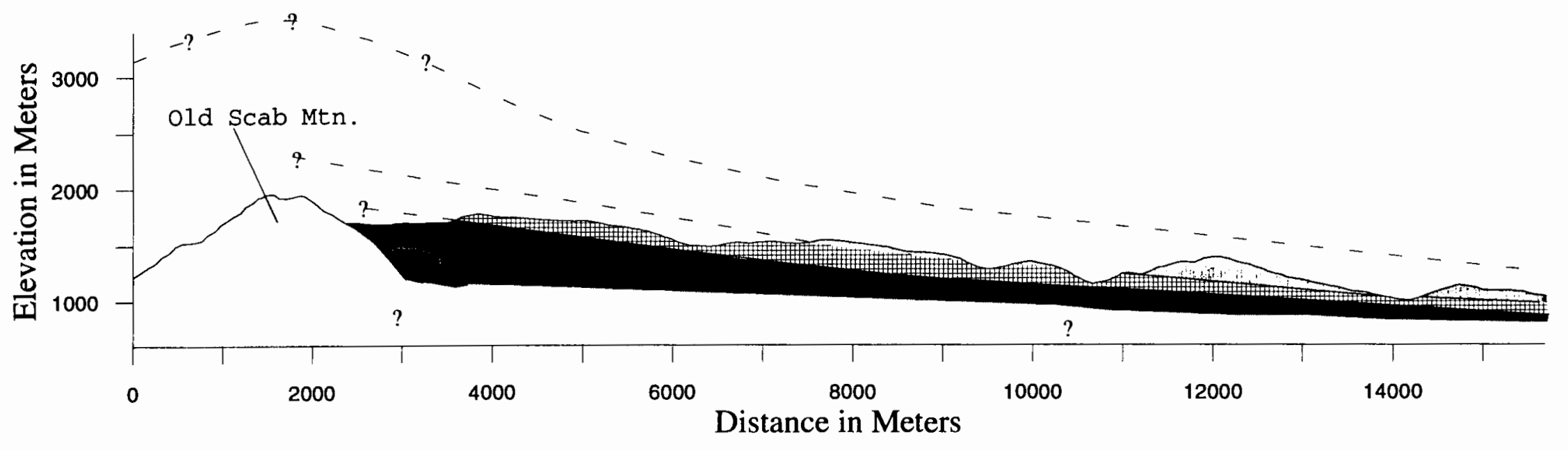

Upper Ellensburg Formation

Fifes Peaks Formation

$\square$ Dacite of Old Scab Mt.

Tertiary porphyritic andesite intrusion

Grande Ronde Basalt

_ _ _ Inferred contact

Figure 54 - Cross section extending from old Scab Mountain east-southeast into the Nile Basin. 
southeast into the Nile basin. By extending an inferred contact from the base of the Grande Ronde Basalt east toward Old Scab Mountain it is possible to show that the top of old Scab Mountain protrudes above the inferred base of Grande Ronde Basalt (Fig. 54). Furthermore, Old Scab Mountain has been extensively eroded by glaciation and other degradation processes which has reduced its overall vertical height. The original intrusive body probably extended above the current upper contact of the Grande Ronde Basalt. This suggests that old Scab Mountain was emplaced after the deposition of the basalts, and consequently would have an age younger than 15.6 to $16.5 \mathrm{Ma}$ (age of Grande Ronde Basalt; Tolan and others, 1989). Based on the age of the adjacent sill, an age of between 9 to $7 \mathrm{Ma}$ can be assumed for the dacite of old scab Mountain.

Chemical Correlation

Chemical correlation between the Ellensburg Eormation and Old Scab Mountain is difficult due to the inherent differences between the two rock groups. The Ellensburg Formation in the Nile basin consists of a series of volcanic, volcaniclastic, and sedimentary deposits which where deposited within a period of approximately $5 \mathrm{Ma}$ and represent many eruptive phases. Magma associated with each eruptive phase 
probably experienced different degrees of crystal fractionation, magma mixing and contamination. Whereas, old Scab Mountain is chiefly a single dacitic intrusive body of nearly uniform geochemical composition and represents a single geologic event. It is apparent that the magma body which formed old Scab Mountain cannot be the sole magma source for all the Ellensburg deposits in the basin. Therefore, comparison of rock chemistries must be conducted in the broad sense and should not be perceived as the matching of "finger prints".

Major element distributions show two distinct groupings in the Ellensburg Formation. Dacite clasts from the lower Ellensburg Formation contain higher concentrations of $\mathrm{K}_{2} \mathrm{O}$, $\mathrm{TiO}_{2}$, and FeO*, lower concentrations of $\mathrm{Na}_{2} \mathrm{O}$ and $\mathrm{CaO}$, and greater $\mathrm{SiO}_{2}$ range than clasts from the upper Ellensburg units (Figs. 39 and 41). Furthermore, most of the lower Ellensburg samples plot within the tholeiitic region of the AFM diagram (Fig. 39), whereas, most of the upper Ellensburg samples plot within the calc-alkaline range.

Dacites from old Scab Mountain consistently plot within the upper silica range of the upper Ellensburg Formation linear trend of all plotted Harker variation diagrams (Fig. 41). Dacite samples also fall within the calc-alkaline range of the AFM diagram (Fig. 39), within upper Ellensburg distribution. 
Trace element concentrations are also very similar between the upper Ellensburg Formation and old Scab Mountain. Chondrite normalized spider diagrams (Figs. 49 and 50) show similar patterns between the two groups of rocks. In cluster diagrams, Old Scab Mountain plots within the well-defined distribution of the upper Ellensburg Formation, with respect to $\mathrm{Rb}, \mathrm{Ba}, \mathrm{Sr}, \mathrm{Th}, \mathrm{Ti}, \mathrm{Zr}$, Nd and $\mathrm{Y}$ (Figs. 43 though 46 ). Whereas, the lower Ellensburg samples show different and more dispersed distributions and are generally higher in $\mathrm{Ba}, \mathrm{Rb}$, Th, Ta, La, Sm, Y, and Yb, and lower in Sr.

Statistical comparisons using correlation coefficients suggest strong similarities between the upper Ellensburg Formation and Old Scab Mountain, with lesser degrees of similarity between the lower Ellensburg Formation and old Scab Mountain or upper Ellensburg Formation (Fig. 41). Q-mode factor analysis suggest similar variance distributions in multidimensional space between the upper Ellensburg Formation and Old Scab Mountain, as is represented by the plot of the second and third Q-mode factors in Figure 53 (Davis, 1986). However, this similarity is not seen in the lower Ellensburg samples, which form the distribution pattern in Figure 53.

Sample \#94019, which represents the dacitic sill exposed west of old Scab Mountain, compares well with old Scab Mountain dacite samples. However, correlation coefficients of trace element data, show a relatively poor correlation of 
Sample \#94020 with Old Scab Mountain. Sample \#94020 is a dacitic intrusive rock collected near the southern flank of old Scab Mountain, and may be more closely associated with a younger dacite intrusive body to the south of old scab Mountain.

Geochemical data and statistical analysis suggests that the upper Ellensburg Formation and the dacite of old Scab Mountain are similar in both major and trace element geochemistry. However, these similarities are not demonstrated in the lower Ellensburg Formation, which shows differences in both major and trace element geochemistry when compared to the upper Ellensburg Formation or the dacite of Old Scab Mountain.

\section{FERROMAGNESIUM SILICATE QUANTITATIVE ANALYSIS}

Evaluation of modal analyses from old Scab Mountain and upper Ellensburg rocks clearly show a large difference in hornblende, orthopyroxene and, to a lesser extent, biotite concentration between the two units. Old Scab Mountain rocks show substantially less hornblende and more orthopyroxene and slightly less biotite than do Ellensburg rocks. This disparity can be argued to be the result of hornblende and biotite breakdown to orthopyroxene in old Scab Mountain dacites, as has been discussed above. However, because of total breakdown of most hydrous phases in Old Scab Mountain 
dacite, it is unclear whether the original minerals were hornblende, biotite or a third, unknown, mineral

Figure 55 shows three log-log plots which compare the modal data of hornblende and biotite against orthopyroxene microlites. Only orthopyroxene microlites are plotted because orthopyroxene microlites, and not orthopyroxene phenocrysts, would be the breakdown product of hornblende and biotite. Correlation coefficients have been calculated for all three plots (Fig. 55). These correlation coefficients were tested for significance using the T-test with 16 degrees of freedom and a significance level of 58. Correlation coefficients were calculated to determine whether a correlation exists between volume of hornblende and biotite phenocrysts and volume of orthopyroxene microlites. Hornblende versus orthopyroxene and hornblende + biotite versus orthopyroxene show strong negative correlation coefficients and have critical values less than their " $T$ " statistical value and therefore show real correlations. These results show that as hornblende or hornblende + biotite decrease, orthopyroxene increase. However, biotite versus orthopyroxene showed less strong negative correlation coefficients and have a critical value greater than its " $T$ " statistical value and, therefore, it could not be shown to be a real correlation. Although the correlation between biotite and orthopyroxene is not shown, the correlation between 
(a)

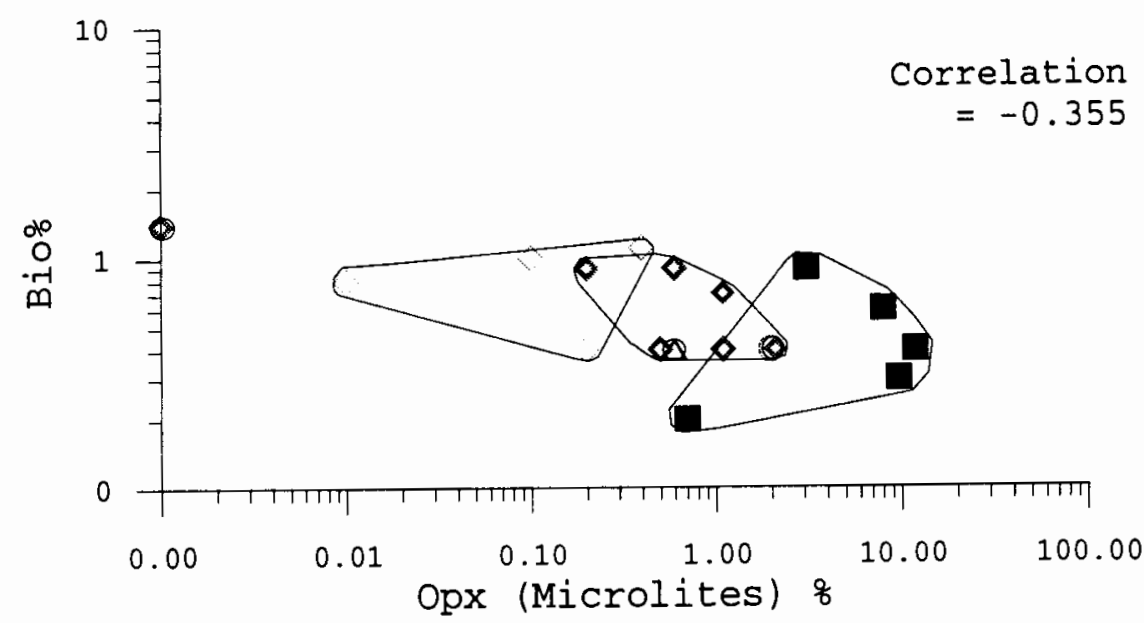

(b)

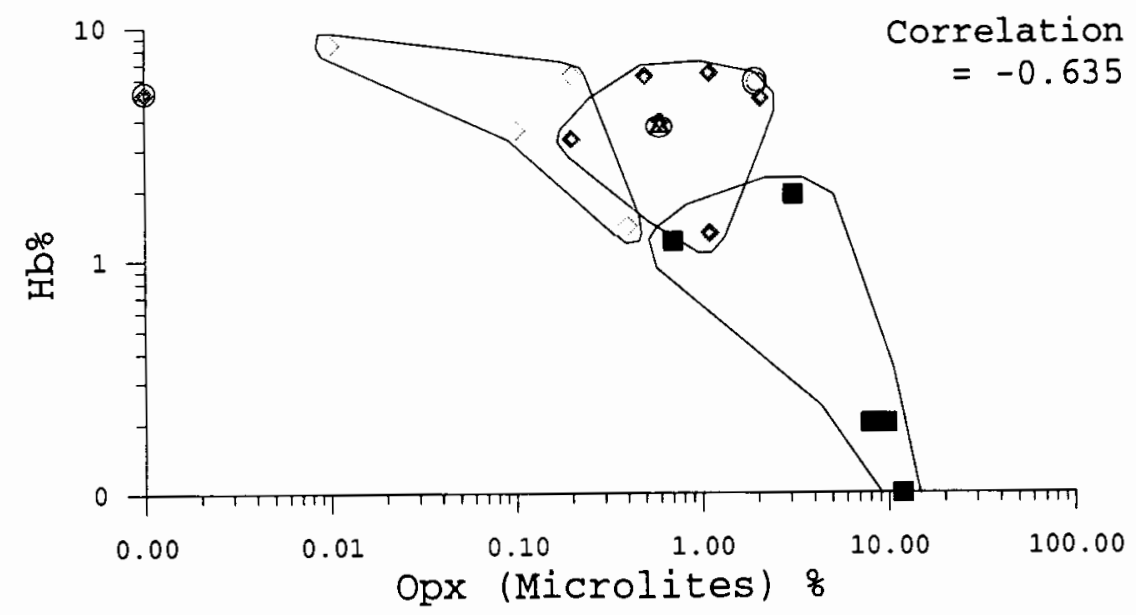

(c)

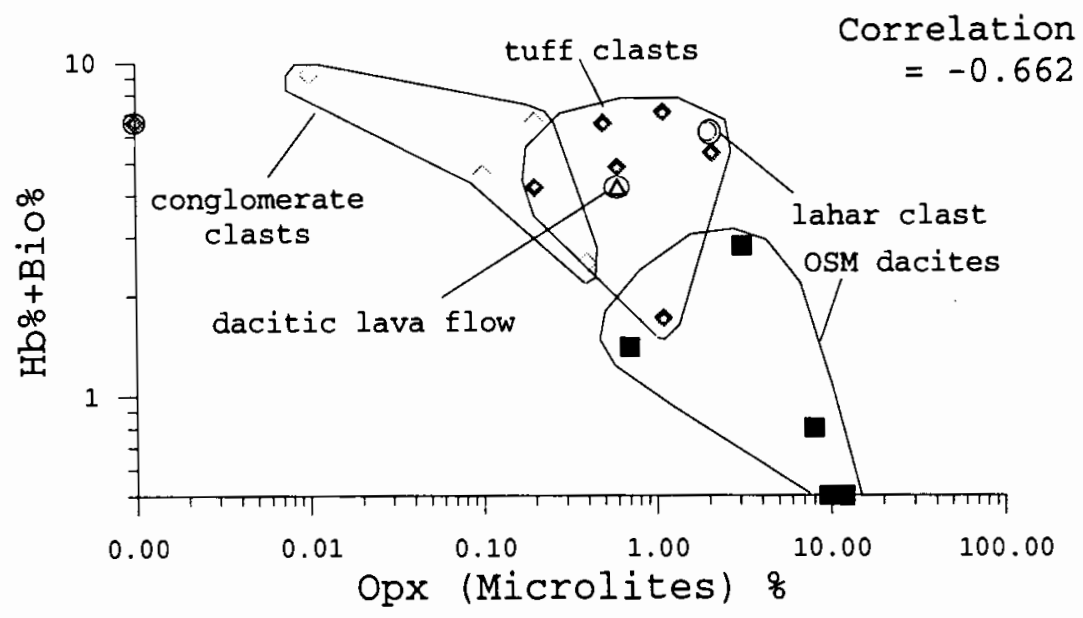

Figure 55 - Hydrous phase mineral percentage plotted against orthopyroxene microlites of upper Ellensburg rocks and dacites from Old Scab Mountain (OSM). (a) Biotite versus orthopyroxene, (b) Hornblende versus Orthopyroxene, (c) Hornblende + Biotite versus orthopyroxene. Symbols are shown in plot (c). 
hornblende + biotite and orthopyroxene is greater than the correlation between hornblende and orthopyroxene alone; therefore, the breakdown of biotite plays a role in the concentrations of orthopyroxene. In dacite of old Scab Mountain the breakdown of biotite to orthopyroxene is not as significant as the breakdown of hornblende because biotite crystals have only a thin reaction rim, whereas almost all hornblende crystals experienced complete replacement.

\section{EMPLACEMENT DEPTH OF THE DACITE OF OLD SCAB MOUNTAIN}

Although Old Scab Mountain correlates well with the upper Ellensburg Formation in respect to location, age, and chemistry, it has not been determined if magmas from the intrusive body erupted at the surface. Because all the geologic units overlying old Scab Mountain have long since eroded, including any possible conduits to the surface, the depth of intrusion plays an important role in answering this question.

The breakdown of hydrous phase minerals, such as hornblende and biotite, gives information about the depth of emplacement. Hornblende stability experiments at $800 \mathrm{MPa}$ show that hornblende reaches its greatest stability (at $\sim 980^{\circ} \mathrm{C}$ ) when 4.5 weight percent $\mathrm{H}_{2} \mathrm{O}$ is present in the system (Naney, 1983). A minimum of 160 to $200 \mathrm{MPa}$ at 4 wt percent $\mathrm{H}_{2} \mathrm{O}$ (greater than $6.5 \mathrm{~km}$ depth) is required for continued 
hornblende stability (Rutherford and Hill, 1993; Rutherford, 1993; Naney, 1983). If the amount of $\mathrm{H}_{2} \mathrm{O}$ in the system decreases, the overall pressure on the system must increase for hornblende to remain stable.

Biotite remains stable even when $\mathrm{H}_{2} \mathrm{O}$ in the system is 0.5 weight percent or less (Naney, 1983). Therefore, the stability of biotite is maintained at shallower depth even as hornblende begins to breakdown.

Petrographic analysis of rock samples from old Scab Mountain reveals almost complete breakdown of hornblende and, to a lesser extent, biotite to orthopyroxene. Such breakdown is common in dacitic magmas which cooled at depths shallower than $6.5 \mathrm{~km}$. Recently, measurement of reaction rim widths has been used to determine magma assent rates for the 1980 to 1986 Mount St. Helen eruptions (Rutherford and Hill, 1993; Rutherford, 1993). These same studies revealed that dacitic magmas stored at depths less than $6.5 \mathrm{~km}$ for more than 11 days can experience almost complete breakdown of hornblende to orthopyroxene and other breakdown products. This suggests that old Scab Mountain was intruded at depths shallower than $6.5 \mathrm{~km}$. Furthermore, the top of old Scab Mountain is more than $1 \mathrm{~km}$ above its exposed base which places its top no more than $5.5 \mathrm{~km}$ in depth. The lack of any flow textures or disruption and scattering of the fine-grained clots of 
breakdown products suggests that most of the replacement of hornblende and biotite occurred after emplacement of the intrusion.

Final determination of depth depends on the total thickness of deposits which overlaid Grande Ronde Basalt during time of intrusion. Presently, up to 350 to $400 \mathrm{~m}$ of deposits overlie Grande Ronde Basalt within the Nile and Selah basins. These deposits consist chiefly of upper Ellensburg Formation. The original thickness of these deposits in the Nile basin prior to extensive erosion is unknown, and therefore, determining the exact depth of the intrusion is difficult. However, it is unlikely that there was more than 3 $\mathrm{km}$ of material overlying Grande Ronde basalt at the time of intrusion. Greater thicknesses than $3 \mathrm{~km}$ require an overlying volcanic edifice taller than the tallest volcanoes currently present in the Cascade Range, or require a basin greater than $3 \mathrm{~km}$ in depth, for which there is no evidence.

Emplacement depth shallower than $1 \mathrm{~km}$ in depth is also unlikely, because at such depths vesiculation of dacitic magmas occurs and there is no evidence for such vesiculation in the exposed dacite of old Scab Mountain. Therefore, the emplacement depth of the dacite of old Scab Mountain is likely between 1 to $3 \mathrm{~km}$. 
ERUPTIVE AND DEPOSITIONAL HISTORY

Volcaniclastic deposits within the Nile basin consist of pyroclastic flow, lapilli and ash fall, lahar, and debris avalanche deposits, most of which are products of plinian eruptions. Dacitic clasts found within the lahar and debris avalanche deposits are primarily open-textured as the result of microvesiculation of the rock prior to cooling. Such opentextured clasts are typically associated with domal rocks (Smith and others, 1988; Williams and McBirney, 1979), and suggest a dome-growth component to the volcanic eruptions. Dome collapse may have been triggered by small eruptions or explosive degassing of the dome itself, as described by sato and others (1992). Such dome collapse caused debris avalanches and, if the debris is mixed with water, lahars. Lahar deposits overlying pyroclastic-flow deposits suggest that dome growth and collapse occurred after Plinian eruptions.

The depositional record indicates that most volcanically active phases were followed by periods of extensive fluvial sedimentation. Volcanic sandstone and matrix-supported dacitic conglomerate is commonly overlain by less volcanic sandstone and thick clast-supported conglomerate. This depositional sequence shows a reduction of fine-grained 
volcanic component available in the system. The high percentage of conglomerate in the geologic record shows that a large amount of cobble- to boulder-sized material was readily available for transport. This material was probably supplied by reworking of lahar and debris avalanche deposits. Pyroclastic flow deposits also contain large clast-size material; however, the clasts consist primarily of pumice which is quickly broken down during fluvial transport. Although pumice clasts/cobbles have been found in conglomerate deposits, the total amount is small, and therefore the reworking of pyroclastic flow deposits is not a major supplier of cobble sized material to conglomerate deposits.

The lower Ellensburg Formation contains the largest amount of basaltic/basaltic andesite clasts. These clasts probably originated as eroded material from older Fifes Peaks Formation or equivalent rocks, although no geochemical comparisons have been made. Laharic deposits consisting of mixtures of pumice and ash, and angular basaltic fragments (Fig. 18) may have originated from explosive dacitic eruptions erupting through older basaltic rock. In the upper Ellensburg Formation the amount of basaltic clasts decreases up section. Many clasts show textural similarities to Grande Ronde Basalt and probably originated from erosion of exposed outcrops. The 
decrease in number of basaltic clasts up section probably represents the thickening of Ellensburg deposits and covering of the basalts.

Two distinctive stratigraphic units define the Ellensburg Formation in the Nile Basin. The lower Ellensburg Formation is found underlying the Grande Ronde Basalt and is probably between 16 to $19.5 \mathrm{Ma}$. The upper Ellensburg Formation overlies the Grand Ronde Basalt and ranges in age from 11.28 to $7.0 \mathrm{Ma}$ (Smith and others, 1989b). The Selah and Vantage Members of the Ellensburg Formation (Fig. 3), which are found in the Selah, Naches and Yakima basins to the east, are absent in the Nile basin. The Selah and Vantage Members overly the Grande Ronde Basalt and underlie the Pomona Member of the Columbia River Basalt Group and range in age from 15.6 to $12 \mathrm{Ma}$. The lack of these Ellensburg units in the $\mathrm{Nile}$ basin probably represent increased erosion along the eastern Cascade Range as the result of regional uplift. Sediments to the east were largely protected from this erosion by overlying Columbia River Basalt flows and less uplift.

\section{Magmatic Reservoir}

As discussed in previous sections, old Scab Mountain was probably emplaced at a depth of 1 to $3 \mathrm{~km}$. The material overlying the intrusion was largely made up of volcaniclastic deposits of the upper Ellensburg Formation which have since 
been eroded. This large thickness of overlying Ellensburg deposits probably represented the edifice of an eruptive center which was active during the time of deposition of the upper Ellensburg Formation. However, it has not been shown here that the magma chamber, which later formed old Scab Mountain, was conclusively the primary source of the upper Ellensburg deposits within the Nile basin.

Petrographic analysis shows that the extent of hydrous phase mineral breakdown in most of the upper Ellensburg deposits is not as great as that in dacites of old Scab Mountain. This suggests that the primary magma reservoir for the Ellensburg material was deeper than that determined for old Scab Mountain, which allowed higher pressures to maintain hydrous phase mineral stabilization. As discussed previously, breakdown of hornblende begins at depths shallower than 6.5 $\mathrm{km}$. This places a potential magma reservoir for the Ellensburg material at depths greater than $6.5 \mathrm{~km}$. The magma reservoir for Mount st. Helens was determined to be at depths between 6 and $13 \mathrm{~km}$, as determined by an earthquake-free zone (Scandon and Malone, 1985; Malone, 1990). This depth also seems reasonable for the Ellensburg magma reservoir. Hornblende stability was largely maintained in the Ellensburg Formation possibly as the result of a rapid upward magma ascent during eruption and subsequent rapid cooling of Ellensburg deposits. 
Although old Scab Mountain probably is not the main magma reservoir for the majority of the upper Ellensburg material, it may represent a short-lived shallower secondary reservoir fed from magma derived from the deeper, main reservoir. During the first two months of the 1980 eruption of Mount st. Helens a shallow $0.11 \mathrm{~km}^{3}$ dacite "cryptodome" intrusion was emplaced into the north side of the volcano (Pallister and others, 1992). This "cryptodome" intrusion was destroyed by the eruption of May 18, 1980. Although Old Scab Mountain is a much larger intrusion, a similar process possibly occurred. However, geologic mapping has identified few signs of deformation along the perimeter of old scab Mountain, which suggests that most of the deformation which accompanied the intrusive emplacement was taken up by the overlying volcanic edifice. As discussed previously, the overlying volcanic edifice was thick enough to contain an intrusion the size of Old Scab Mountain. This logic assumes that the volcanic edifice formed prior to the emplacement of Old Scab Mountain, and that old Scab Mountain (approximately 9 to $7 \mathrm{Ma}$ represents a late-stage shallow intrusion in a long period of volcanic activity extending from possibly as early as 12 to 7 Ma (Fig. 56). 
(a)

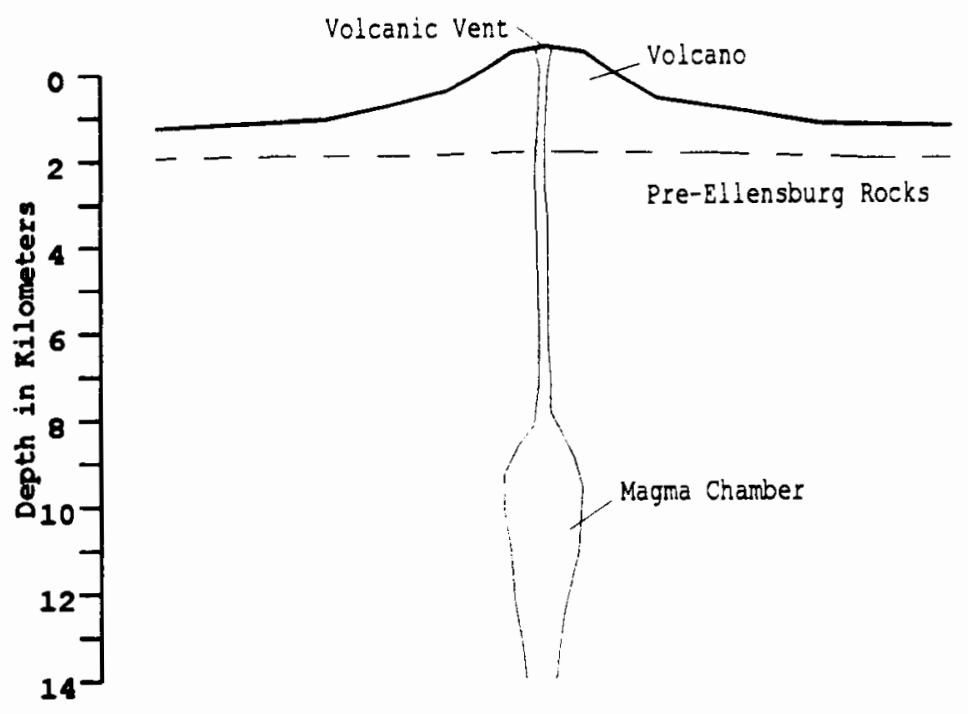

(b)

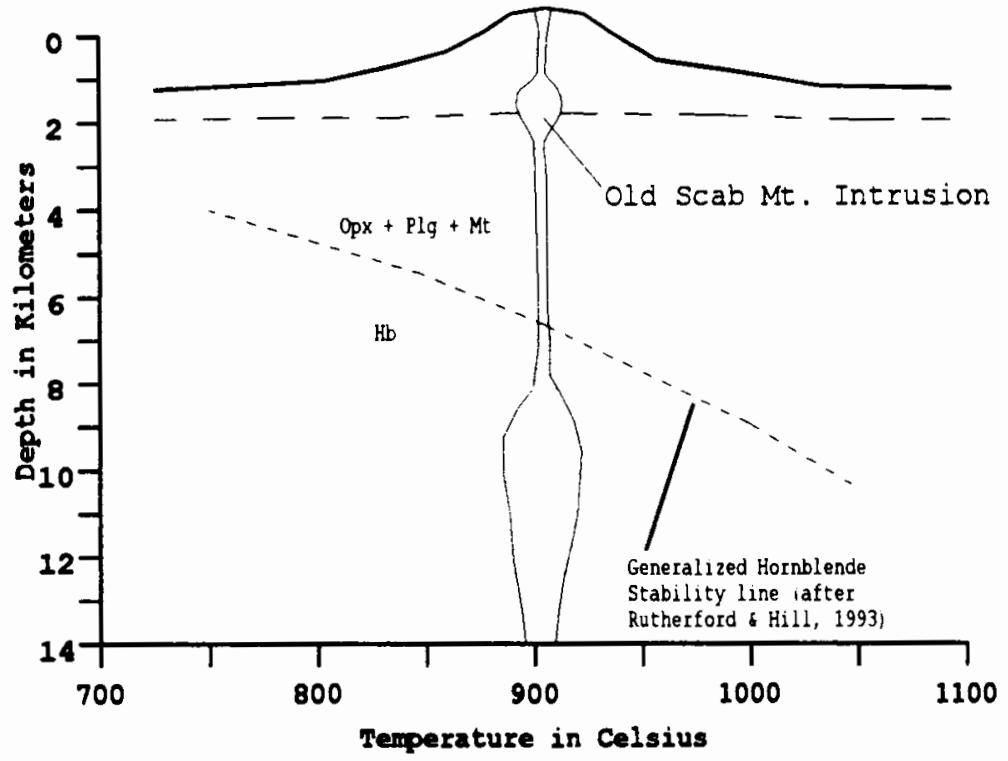

Figure 56 - General diagram illustrating proposed Nile basin volcano (a) prior to the emplacement of the old scab Mountain intrusion, and (b) after the emplacement of the old scab Mountain intrusion. Dashed line defines generalized hornblende ( $H b$ ) stability field. 
EURTHER WORK

Radiometric age determinations were not conducted on rocks from old scab Mountain during this study, although, relative stratigraphic age determination was attempted. The age of old Scab Mountain should be determined to verify intrusive age and correlation with the upper Ellensburg Formation.

Although old Scab Mountain was the focus of this thesis for correlation with the Ellensburg Formation, other Miocene aged dacitic intrusions west of the field area should be studied and compared geochemically with the Ellensburg Formation. The Ellensburg Formation represents extensive volcaniclastic deposits and probably was derived from many volcanic sources.

The Selah and Vantage Members of the Ellensburg Formation are not present in the Nile basin and should be studied for their geochemical and depositional similarities to the lower and upper Ellensburg Formation. 


\section{CONCLUSION}

The Ellensburg Formation consists of a series of middle to late Miocene dacitic epiclastic and pyroclastic rock assemblages. Two stratigraphic units have been identified in the Nile basin which are separated by Grande Ronde Basalt of the Columbia River Basalt Group. The lower Ellensburg Formation underlies the Grande Ronde Basalt and is between 16 to $19.5 \mathrm{Ma}$ in age. The upper Ellensburg Formation overlies the Grande Ronde Basalt and ranges in age between 11.3 to 7.0 Ma. The Selah and Vantage Members of the Ellensburg Formation (15.6 to $12 \mathrm{Ma}$ ), exposed to the east of the Nile basin, are not present in the Nile basin and may have been removed by erosion before the upper Ellensburg Formation was deposited. Geochemical analysis shows that lower Ellensburg Formation contains higher concentrations of $\mathrm{K}_{2} \mathrm{O}, \mathrm{TiO}_{2}$, and Feo*, $\mathrm{Ba}, \mathrm{Rb}, \mathrm{Th}, \mathrm{Ta}, \mathrm{La}, \mathrm{Sm}, \mathrm{Y}$, and $\mathrm{Yb}$ and lower $\mathrm{Na}_{2} \mathrm{O}, \mathrm{CaO}$, and Sr than upper Ellensburg Formation. Lower Ellensburg Formation is also tholeitic in composition, whereas, upper Ellensburg Formation is primarily calc-alkaline. This compositional difference suggests that the lower and upper Ellensburg Formation were derived from at least two different magma sources. 
The presence of thick accumulations of pyroclastic flow deposits, massive lahar deposits, volcanic debris avalanche deposits, and a dacitic lava flow suggest that the Ellensburg Formation in the Nile basin represents a proximal facies within 15 to $20 \mathrm{~km}$ of the volcanic source.

Old Scab Mountain, located along the western margin of the Nile basin, is a dacitic intrusion which was emplaced at the base of a volcanic edifice approximately 1 to $3 \mathrm{~km}$ in depth, 9 to $7 \mathrm{Ma}$ ago. It is interpreted as the remnant of a volcanic center which was active during the time of deposition of the upper Ellensburg Formation. Dacites of Old Scab Mountain and upper Ellensburg Formation have similar geochemistry, suggesting that they had a similar, possibly the same, magma source.

This geochemical data, together with stratigraphy and petrography, suggest that much of the upper Ellensburg Formation's volcaniclastic material originated from a volcanic center now defined by the intrusion of old scab Mountain. The magma reservoir for most of this material was located at depths greater than $6.5 \mathrm{~km}$. Late in the volcanic activity dacite magma was intruded in the base of the volcanic edifice, and now is exposed as old Scab Mountain.

At least one dacite sill, similar to old Scab Mountain dacite, was also emplaced west of old Scab Mountain, 
approximately $8 \mathrm{Ma}$ ago. It is unknown if this dacitic sill was emplaced before or after emplacement of old Scab Mountain; however, geochemical and petrographic similarities suggest that the two have a similar magma source. 


\section{REFERENCES}

Bentley, R. D., 1977, Stratigraphy of the Yakima Basalts and structural evolution of the Yakima Ridges in western Columbia Plateau, in Brown, E. H., and Ellis, R. C., eds., Geologic excursions in the Pacific Northwest: Department of Geology, Western Washington University, Bellingham, Washington, p. 339-389.

Bentley, R. D., and Campbell, N. P., 1983, Geologic map of the Ellensburg quadrangle, Washington: Washington Division of Geology and Earth Resources, Geologic Map GM-28, scale $1: 62,500$.

Brantley, S. R., and Waitt, R. B., 1988, Interrelations among pyroclastic surge, pyroclastic flow, and lahars in Smith Creek valley during first minutes of 18 May 1980 eruption of Mount St. Helens, USA: Bulletin of Volcanology, v. 50, p. 304-326.

Cameron, K. A., and Pringle, P., 1986, Post-glacial lahars of the Sandy River basin, Mount Hood, Oregon: Northwest Science, v. 60, p. 225-237.

Campbell, N. P., 1975, A geologic road log over Chinook, White Pass, and Ellensburg to Yakima Highway: Washington Division of Geology and Earth Resources, Information Circular 54, $82 \mathrm{pp}$.

Campbell, N. P., 1989, Structural and stratigraphic interpretation of rocks under the Yakama fold belt, Columbia Basin based on resent surface mapping and well data, in Reidel, S. P., and Hooper, P. R., eds., Volcanism and tectonism in the Columbia River floodbasalt province: Geological Society of America, Special Paper 239, p. 209-223.

Carey, S. N., 1991, Transport and deposition of tephra by pyroclastic flows and surges, in Fisher, R. V., and Smith, G. A., eds., Sedimentation in Volcanic Settings: SEPM Special Publication, no. 45, p. 39-57.

Carkin, B. A., 1988, The geology and petrology of Fifes Peak Formation in the Cliffdell area, Central Cascades, Washington: Western Washington University, Bellingham, Washington, Masters Thesis, $157 \mathrm{p}$.

Cas, R. A. F., and Wright, J. V., 1987, Volcanic successions: Modern and ancient: London, Chapman \& Hall, 528 pp. 
Compton, R. R., 1985, Geology in the Field: New York, John Wiley \& Sons, $398 \mathrm{pp}$.

Coombs, H. A., 1941, Hornblende and magnetite heavies in the Ellensburg of central Washington: Journal of Sedimentary Petrology, v. 11, no. 3, p. 142-144.

Davis, J. C., 1986, statistics and data analysis in geology, 2nd ed.: New York, John Wiley \& Sons, $646 \mathrm{p}$.

Defant, M. J., Drummond, M. S., 1993, Mount St. Helens: Potential example of the partial melting of the subducted lithosphere in a volcanic arc: Geology, v.21, p. 547-550.

Fisher, R. V., and Schmincke, H.-U., 1984, Pyroclastic rocks: New York, Springer-Verlag, $472 \mathrm{p}$.

Fisher, R. V., and Smith, G. A., 1991, Volcanism, tectonics and sedimentation, in Fisher, R. V., and Smith, G. A., eds., sedimentation in Volcanic settings: SEPM Special Publication, no. 45, p. 1-5.

Fiske, R. S., Hopson, C. A., and Waters, A. C., 1963, Geology of Mount Rainier National Park, Washington: U.S. Geological Survey Professional Paper 444, 93 p.

Frizzell, V. A., Jr., Tabor, R. W., Booth, D. B., Ort, K. M., and Waitt, R. b., Jr., 1984, Preliminary geologic map of the snoqualmie Pass 1:100,000 quadrangle, Washington: U.S. Geological Survey Open-File Report OF-84-693.

Garcia, M. O., and Jacobson, S. S., 1979, Crystal clots, amphibole fractionation and the evolution of calcalkaline magmas: Contributions to Mineralogy and Petrology, v. 69, p. 319-327.

Glicken, H., 1991, Sedimentary architecture of large volcanicdebris avalanches, in Fisher, R. V., and Smith, G. A., eds., sedimentation in Volcanic settings: SEPM Special Publication, no. 45, p. 99-106

Guffanti, M., and Weaver, C. S., 1988, Distribution of late Cenozoic volcanic vents in the Cascade Range: Volcanic arc segmentation and regional tectonic considerations: Journal of Geophysical Research, v. 93, p. 6513-6529. 
Hammond, P. E., 1980, Reconnaissance geology map of southern Washington Cascade Range, Latitude $45^{\circ} 30^{\prime}-47^{\circ} 15^{\prime} \mathrm{N}$. , Longitude $120^{\circ} 45^{\prime}-122^{\circ} 22.5^{\prime}$ W. : Publications of the Department of Earth Sciences, Portland State University, Portland, Oregon.

Hammond, P. E., 1989, Guide to geology of the Cascade Range, 28 th International Geological Congress, Field Trip Guidebook T306: America Geophysical Union, Washington, DC, 215 p.

Hammond, P. E., and Hooper. P. R., 1991, Fifes Peak Formation, Washington Cascade Range: 14th Annual Meeting, Oregon Academy of Science, Monmouth, or.

Hammond, P. E., Brunstad, K. A., and King, J. F., 1994, MidTertiary volcanism east of Mount Rainier: Fifes Peaks Volcano-Caldera and Bumping Lake Pluton-Mount Aix Caldera, in Swanson, D. A., and Haugerud, R. A., eds., Geologic field trips in the Pacific Northwest: 1994 Geological Society of America Annual Meeting, Seattle, Washington, $19 \mathrm{p}$.

Hartman, D. A., 1973, Geology and low-grade metamorphism of the Greenwater River area, central Cascade Range, Washington: University of Washington, Seattle, washington, Ph.D. Thesis, 99 pp.

Hess, P. C., 1989, Origin of Igneous Rocks: Harvard University Press, Cambridge, 336 pp.

Hooper, P. R., Johnson, D. M., and Conrey, R. M., 1993, Major and trace element analyses of rocks and minerals by automated X-ray spectrometry: Washington state University, Geology Department, Pullman, Washington, Open File Report, $36 \mathrm{p}$.

Irvine, T. N. and Baragar, W. R. A., 1971, A guide to the chemical classification of the Common volcanic rocks: Canadian Journal of Earth Science, v. 8, p. 523-548.

Jakeš, P., and White, A. J. R., 1972, Hornblendes from calcalkaline volcanic rocks of island arcs and continental margins: American Mineralogist, v. 57, p. 887-902.

King, J. F., 1994, Magmatic evolution and eruptive history of the granitic Bumping Lake Pluton, Washington: Source of the Bumping River and Cash Prairie Tuffs: Portland State University, Portland, Oregon, Masters Thesis, $71 \mathrm{p}$. 
Laval, W. N., 1948, An investigation of the Ellensburg Formation: Washington State University, Pullman, Washington, Masters Thesis.

Luker, J. A., 1985, Sedimentology of the Ellensburg Formation northwest of Yakima, Washington: Eastern Washington University, Cheney, Washington, $184 \mathrm{p}$.

Mackin, J. H., 1961, A stratigraphic section in the Yakima Basalt and the Ellensburg Formation in south-central Washington: Washington Division of Mines and Geology Report Investigation 19, p. 1-45.

Malone, S. D., 1990, Mount St. Helens, the 1980 rewakening and continuing seismic activity: Geoscience Canada, v. 17, p. 146-149.

McBirney, A. R., 1993, Igneous petrology: Boston, MA., Jones and Bartlett Publishers, $507 \mathrm{p}$.

McBirney, A. R., and White, C. M., 1982, The Cascade Province, in Thorpe, R. S., Andesites: Orogenic Andesites and Related Rocks: New York, John Wiley and Sons Ltd., p. 115-135.

Miller, R. B., 1989, The Mesozoic Rimrock Lake inlier, southern Washington Cascades: Implications for the basement to the Columbia Embayment: Geological society of America Bulletin, v. 101, p. 1289-1305.

Mueller, R. F., 1972, Stability of biotite: A discussion: American Mineralogist, v. 57, p. 300-316.

Naney, M. T., 1983, Phase equilibria of rock-forming ferromagnesian silicates in granitic systems: American Journal of Science, v. 283, p. 993-1033.

Pallister, J. S., Hoblitt, R. P., Crandell, D. R., and Mollineaux, D. R., 1992, Mount st. Helens a decade after the 1980 eruption: magmatic models, chemical cycles, and a revised hazards assessment: Bulletin of Volcanology, v. 54, p. 126-146.

Pearce, J. A., and Norry, M. J., 1979, Petrogenetic implications of $\mathrm{Ti}, \mathrm{Zr}, \mathrm{Y}$, and $\mathrm{Nb}$ variations in volcanic rocks: Contributions to Mineralogy and Petrology, v. 69, p. $33-47$. 
Pearce, J. A., Harris, N. B. W., and Tindle, A. G., 1984, Trace element discrimination diagrams for the tectonic interpretation of granitic rocks: Journal of Petrology, v. 25, p. $956-983$.

Peccerillo, A., and Taylor, S. R., 1976, Geochemistry of Eocene calc-alkaline volcanic rocks from the Kastamonu area, northern Turkey: Contributions to Mineralogy and Petrology, v. 58, p. 63-81.

Raisz, E., 1945, The Olympic-Wallowa lineament: American Journal of Science, v. 243a, p. 479-485.

Reidel, S. P., Campbell, N. P., Fecht, K. R., and Lindsey, K. A., 1994, Late Cenozoic structure and stratigraphy of south-central Washington: Washington Division of Geology and Earth Resources Bulletin 80, p. 159-180.

Riddihough, R., 1984, Recent movements of the Juan de Fuca plate system: Journal of Geophysical Research, v. 89, No. B8, p. 6980-6994.

Rodolfo, K. S., 1989, Origin and early evolution of lahar channel at Mabinit, Mayon Volcano, Philippines:

Geological Society of America Bulletin, v. 101, p. 414426.

Russell, I. C., 1893, A geological reconnaissance in central Washington: U.S. Geological Survey, Bulletin 108, 108 p.

Russell, I. C., 1900, A preliminary paper on the geology of the Cascade Mountains in northern Washington: U.S. Geological Survey, 20th Annual Report, Pt. 2, p. 83-210.

Rutherford, M. J., 1993, Experimental petrology applied to volcanic processes: EOS, Transactions, American Geophysical Union, v. 74, p. $49 \& 55$.

Rutherford, M. J., and Hill, P. M., 1993, Magma ascent rates from amphibole breakdown: An experimental study applied to the 1980-1986 Mount St. Helens eruptions: Journal of Geophysical Research, v. 98, p. 19,667-19,685.

Scandone R., and Malone, S. D., 1985, Magma supply, magma discharge and readjustment of the feeding system of Mount St. Helens during 1980: Journal of Volcanology and Geothermal Research, v. 23, p. 239-262.

Schasse, H. W., 1987, Geologic map of the Mount Rainier quadrangle, Washington: Washington Division of Geology and Earth Resources, Open Rile Report 87-16, 43 p. 
Schmincke, H. -U., 1964, Petrology, paleocurrents, and stratigraphy of the Ellensburg Eormation and interbedded Yakima basalt flows [Ph.D. dissertation]: Baltimore, Johns Hopkins University, $426 \mathrm{p}$.

Schmincke, H. -U., 1967a, Graded lahars in the type sections of the Ellensburg Formation, south-central Washington: Journal of Sedimentary Petrology, v. 37, p. 438-448.

Schmincke, H. -U., 1967b, Fused tuff and pépérites in southcentral Washington: Geological Society of America Bulletin, v. 78, p. 319-329.

Schreiber, S. A., 1981, Geology of the Nelson Butte area, South-central Cascade Range, Washington: University of Washington, Masters Thesis, $81 \mathrm{p}$.

Schumacher, R., and Schmincke, H. -U., 1990, The lateral facies of ignimbrites at Laacher see volcano: Bulletin of Volcanology, v. 52, p. 271-285.

Self, S., 1988, Terminology and classification of pyroclastic deposits, in Ayres, L. D., ed., Pyroclastic volcanism and deposits of Cenozoic intermediate to felsic volcanic islands: With implications for Precambrian greenstonebelt volcanoes: Geological Association of Canada Short Course Notes, v. 2, p. 18-37.

Shultz, J. M., 1988, Mid-Tertiary volcanic rocks of the Timberwolf Mountain area, south-central Cascades, Washington: Western Washington University, Bellingham, Washington, Masters Thesis, $145 \mathrm{p}$.

Siebert, L., Glicken, H., and Kienle, J., 1989, Debris avalanches and lateral blasts at Mount St. Augustine Volcano, Alaska: National Geographic Research, v. 5, p. 232-249.

Smiley, C. J., 1963, The Ellensburg Flora of Washington: University California Publications of Geologic Sciences, v. 35, p. 159-276.

Smith, G. A., 1986, Simtustus Formation: Paleogeographic and stratigraphic significance of a newly defined Miocene unit in the Deschutes basin, central oregon: Oregon Geology, v. 48, p. 63-72. 
Smith, G. A., 1988a, Sedimentology of proximal to distal volcaniclastics dispersed across an active foldbelt: Ellensburg Formation (late Miocene), central Washington: sedimentology, $v .35$, p. 953-977.

Smith, G. A., 1988b, Neogene synvolcanic and syntectonic sedimentation in central Washington: Geological Society of America Bulletin, v. 100, p. 1479-1492.

Smith, G. A., 1991a, Facies sequences and geometries in continental volcaniclastic sediments: Sedimentation in Volcanic Settings, SEPM Special Publication, No. 45, p. 109-121.

Smith, G. A., 1991b, A field guide to depositional processes and facies geometry of Neogene continental volcaniclastic rocks, Deschutes basin, central oregon: oregon Geology, v. 53, p. 3-20.

Smith, G. A., Bjornstad, B. N., and Fecht, K. R., 1989a, Neogene terrestrial sedimentation on and adjacent to the Columbia Plateau, Washington, Oregon, and Idaho, in Reidel, S. P., and Hooper, P. R., eds., Volcanism and tectonism in the Columbia River flood-basalt province: Geological Society of America Special Paper 239, p. 187197.

Smith, G. A., Shafiqullah, M., Campbell, N. P., and Deacon, M. W., 1989b, Geochronology of the Ellensburg Formation -constraints on Neogene volcanism and stratigraphic relationships in central Washington: Isochron/West, No. 53, p. 28-32.

Smith, G. A., Campbell, N. P., Deacon, M. W., and Shafiqullah, M., 1988, Eruptive style and location of volcanic centers in the Miocene Washington Cascade Range: Reconstruction from the sedimentary record: Geology, $v$. 16 , p. 337-340.

Smith, G. O., 1901, Geology and water resources of a portion of Yakima county, Washington: U.S. Geological Survey water-Supply Paper 55, $68 \mathrm{p}$.

Smith, G. O., 1903, Description of the Ellensburg quadrangle, Washington: U.S. Geological Survey, Geologic Atlas, Folio 89, $7 \mathrm{p}$.

Sato, H., Fujii, T., and Nakada, S., 1992, Crumbling of dacite dome lava and generation of pyroclastic flows at unzen volcano: Nature, v. 360, p. 664-666. 
Sun, S. S., and MCDonough, W. F., 1989, Magmatism in the Ocean Basins: Geological Society of America Special Publication, No. 42, p. 313-345.

Swanson, D. A., Wright, T. L., Hooper, P. R., and Bentley, R. D., 1979, Revisions in stratigraphic nomenclature of the Columbia River Basalt Group: U.S. Geological Survey Bulletin, No. 1457-G, 59 p.

Thompson, R. N., Dickin, A. P., Gibson, I. L., and Morrison, M. A., Elemental fingerprints of isotopic contamination of Hebridean Paleocene mantle-derived magmas by Archaean Sial: Contributions to Mineralogy and Petrology, v. 79, p. 159-168.

Thorpe, R. S., Francis, P. W., and O'Callaghan, L., 1984, Relative roles of source composition, fractional crystallization and crustal contamination in the petrogenesis of Andean volcanic rocks: Philosophical Transactions of the Royal Society of London, A 310, p. 675-692.

Tolan, T. I., Reidel, S. P., Beeson, M. H., Anderson, J. I., Fecht, K. R., and Swanson, D. A., 1989, Revisions to the estimates of the areal extent and volume of the Columbia River Basalt Group, in Reidel, S. P., and Hooper, P. R., eds., Volcanism and tectonism in the Columbia River flood-basalt province: Geological Society of America Special Paper 239, p. 1-20.

Vance, J. A., Clayton, G. A., Mattinson, J. M., and Naeser, C. W., 1987, Early and middle Cenozoic stratigraphy of the Mount Rainier-Tieton River area, southern Washington Cascades: Washington Division of Geology and Earth Resources Bulletin 77, p. 269-290.

Walker, G. P. L., 1973, Lengths of lava flows: Philosophical Transactions of the Royal Society of London, A. 274, p. 107-118.

Walsh, T. J., Korosec, M. A., Phillips, W. M., Logan, R. L., and Schasse, H. W., 1987, Geologic map of washington southwest quadrant, scale 1:250,000: Washington Division of Geology and Earth Resources, Geologic Map GM-34.

Warren, W. C., 1941, Relation of the Yakima basalt to the Keechelus andesitic series: Journal of Geology, v. 49, p. 795-814. 
Waters A. C., 1955, Geomorphology of south-central Washington, illustrated by the Yakima East quadrangle: Geological Society of America Bulletin, v. 66, p. 663-684.

Williams, H., and McBirney, A., 1979, Volcanology: San Francisco, Freemont Cooper, 397 p.

Wilson, M., 1989, Igneous petrogenesis: A global tectonic approach: Allen \& Unwin (eds), London, Unwin Hyman. 466 p.

Winters, W. J., 1984, stratigraphy and sedimentology of Paleogene arkosic and volcaniclastic strata, Johnson Creek-Chambers Creek area, southern Cascade Range, Washington: Portland State University, Portland, Oregon, Masters Thesis, $162 \mathrm{p}$.

Wright, T. L., Mangan, M., and Swanson, D. A., 1989, Chemical data for flows and feeder dikes of the Yakima Basalt Subgroup, Columbia River Basalt Group, Washington, Oregon, and Idaho, and their bearing on a petrogenetic model: U.S. Geological Survey Bulletin 1821, 22 p. 
APPENDIX A. XRE ANALYZES

\begin{tabular}{|c|c|c|c|c|c|c|c|c|c|c|c|}
\hline \multirow{3}{*}{$\begin{array}{l}\text { UNIT } \\
\text { Sample }\end{array}$} & \multicolumn{7}{|c|}{ DACITE OF OLD SCAB MOUNTAIN } & \multicolumn{4}{|c|}{ OTHER DACITE INTRUSIONS } \\
\hline & $\mathrm{CCH}$ & $\mathrm{CCH}$ & $\mathrm{CCH}$ & $\mathrm{CCH}$ & $\mathrm{CCH}$ & $\mathrm{CCH}$ & $\mathrm{CCH}$ & PHA & PHA & PHA & PHA \\
\hline & 94019 & 94020 & 94079 & 94080 & 94081 & 94082 & 94083 & 91105 & 92242 & 93070 & 94124 \\
\hline 51028 & 65.62 & 67.17 & 66.82 & 66.99 & 66.93 & 66.93 & 66.90 & 66.04 & 62.02 & 63.41 & 63.66 \\
\hline A1 203 & 16.93 & 16.66 & 17.06 & 17.26 & 17.12 & 17.13 & 17.36 & 17.05 & 16.81 & 15.06 & 16.38 \\
\hline $\mathrm{TiO} 2$ & 0.47 & 0.43 & 0.48 & 0.47 & 0.49 & 0.49 & 0.51 & 0.48 & 0.51 & 0.46 & 0.66 \\
\hline $\mathrm{FeO}^{*}$ & 3.49 & 3.24 & 3.39 & 3.33 & 3.32 & 3.27 & 3.43 & 3.39 & 4.00 & 2.97 & 4.05 \\
\hline $\mathrm{MnO}$ & 0.07 & 0.08 & 0.07 & 0.07 & 0.06 & 0.07 & 0.07 & 0.09 & 0.07 & 0.06 & 0.09 \\
\hline $\mathrm{CaO}$ & 4.50 & 4.22 & 4.85 & 4.76 & 4.56 & 4.75 & 4.72 & 5.15 & 4.73 & 4.27 & 4.67 \\
\hline $\mathrm{MgO}$ & 1.53 & 1.46 & 1.40 & 1.18 & 0.87 & 1.24 & 0.84 & 1.20 & 1.81 & 1.40 & 1.99 \\
\hline $\mathrm{K} 2 \mathrm{O}$ & 1.34 & 1.53 & 1.41 & 1.40 & 1.44 & 1.44 & 1.44 & 1.61 & 1.22 & 1.79 & 1.61 \\
\hline $\mathrm{Na} 2 \mathrm{O}$ & 4.73 & 4.35 & 4.46 & 4.55 & 4.28 & 4.45 & 4.39 & 4.69 & 4.86 & 3.89 & 4.55 \\
\hline P205 & 0.15 & 0.14 & 0.15 & 0.15 & 0.15 & 0.15 & 0.16 & 0.17 & 0.15 & 0.15 & 0.20 \\
\hline$($ Tota 1$)$ & 98.83 & 99.27 & 100.10 & 100.17 & 99.23 & 99.92 & 99.82 & 99.87 & 96.19 & 93.46 & 97.86 \\
\hline $\mathrm{Ni}$ ppm & 7 & 12 & 10 & 9 & 7 & 8 & 10 & 8 & 10 & 13 & 11 \\
\hline $\mathrm{Cr}$ & 12 & 15 & 14 & 16 & 11 & 15 & 15 & 17 & 16 & 11 & 23 \\
\hline sc & 9 & 7 & 10 & 12 & 12 & 9 & 11 & 11 & 13 & 11 & 10 \\
\hline V & 51 & 46 & 56 & 42 & 56 & 59 & 59 & 64 & 64 & 48 & 93 \\
\hline $\mathrm{Ba}$ & 394 & 385 & 422 & 443 & 428 & 438 & 436 & 391 & 357 & 389 & 493 \\
\hline $\mathrm{Rb}$ & 27 & 37 & 30 & 29 & 32 & 30 & 30 & 29 & 24 & 33 & 27 \\
\hline $\mathrm{Sr}$ & 521 & 482 & 532 & 536 & 540 & 526 & 542 & 685 & 542 & 618 & 600 \\
\hline $\mathrm{zr}$ & 131 & 132 & 133 & 133 & 134 & 130 & 135 & 149 & 126 & 144 & 153 \\
\hline$Y$ & 10 & 11 & 10 & 9 & 9 & 9 & 11 & 13 & 10 & 12 & 14 \\
\hline $\mathrm{Nb}$ & 7 & 8 & 10 & 9 & 11 & 10 & 9 & 7 & 5 & 11 & 10 \\
\hline $\mathrm{Ga}$ & 22 & 18 & 18 & 20 & 19 & 18 & 21 & 23 & 21 & 17 & 19 \\
\hline $\mathrm{Cu}$ & 12 & 10 & 8 & 11 & 30 & 11 & 9 & 15 & 11 & 19 & 16 \\
\hline $2 n$ & 53 & 45 & 59 & 60 & 61 & 56 & 58 & 55 & 58 & 51 & 82 \\
\hline $\mathrm{Pb}$ & 5 & 6 & 8 & 7 & 5 & 6 & 9 & 7 & 3 & 7 & 10 \\
\hline La & 16 & 18 & 19 & 13 & 23 & 17 & 24 & 0 & 19 & 21 & 28 \\
\hline $\mathrm{Ce}$ & 41 & 20 & 41 & 29 & 9 & 30 & 41 & 49 & 27 & 44 & 40 \\
\hline $\mathrm{Th}$ & 1 & 4 & 2 & 2 & 1 & 3 & 2 & 3 & 3 & 1 & 4 \\
\hline
\end{tabular}


APPENDIX A. XRF ANALYZES CONTINUED

\begin{tabular}{|c|c|c|c|c|c|c|c|c|c|c|c|}
\hline \multirow{3}{*}{$\begin{array}{l}\text { UNIT } \\
\text { Sample }\end{array}$} & \multicolumn{6}{|c|}{ OTHER DACITE INTRUSIONS } & \multicolumn{5}{|c|}{ UPPER ELLENSBURG FORMATION } \\
\hline & PHA & PHA & PHA & PHA & PHA & PHA & $\mathrm{CCH}$ & $\mathrm{CCH}$ & $\mathrm{CCH}$ & $\mathrm{CCH}$ & $\mathrm{CCH}$ \\
\hline & 92126 & 92144 & 92147 & 92157 & 92207 & 92211 & 94001 & 94006 & 94010 & 94021 & 94023 \\
\hline $\mathrm{SiO} 2 \mathrm{8}$ & 62.28 & 64.99 & 66.70 & 65.51 & 62.63 & 66.93 & 65.11 & 63.74 & 65.88 & 59.82 & 62.23 \\
\hline Al203 & 16.39 & 16.03 & 16.33 & 16.48 & 15.63 & 16.52 & 17.50 & 17.21 & 17.74 & 18.34 & 16.83 \\
\hline TiO2 & 0.63 & 0.56 & 0.48 & 0.54 & 0.60 & 0.43 & 0.57 & 0.64 & 0.59 & 0.73 & 0.51 \\
\hline $\mathrm{FeO}^{\star}$ & 4.44 & 3.72 & 3.28 & 3.89 & 4.14 & 3.18 & 4.03 & 4.28 & 3.64 & 5.88 & 3.43 \\
\hline $\mathrm{MnO}$ & 0.09 & 0.10 & 0.06 & 0.08 & 0.09 & 0.07 & 0.06 & 0.07 & 0.07 & 0.05 & 0.14 \\
\hline $\mathrm{CaO}$ & 5.26 & 4.07 & 3.72 & 5.06 & 4.79 & 4.63 & 5.22 & 5.66 & 5.23 & 4.05 & 4.35 \\
\hline $\mathrm{MgO}$ & 1.86 & 1.90 & 1.04 & 1.41 & 1.76 & 1.29 & 0.66 & 1.71 & 0.70 & 1.58 & 1.57 \\
\hline $\mathrm{K} 2 \mathrm{O}$ & 1.49 & 1.81 & 0.65 & 1.62 & 2.85 & 1.27 & 1.61 & 1.71 & 1.32 & 0.70 & 1.61 \\
\hline $\mathrm{Na} 2 \mathrm{O}$ & 4.28 & 4.05 & 4.74 & 4.18 & 3.19 & 4.49 & 3.93 & 3.51 & 4.41 & 2.26 & 2.90 \\
\hline $\mathrm{P} 205$ & 0.21 & 0.16 & 0.15 & 0.21 & 0.17 & 0.01 & 0.16 & 0.14 & 0.18 & 0.06 & 0.13 \\
\hline (Total) & 96.92 & 97.40 & 97.16 & 98.98 & 95.84 & 98.94 & 98.85 & 98.68 & 99.76 & 93.46 & 93.70 \\
\hline $\mathrm{Ni} \quad \mathrm{ppm}$ & 10 & 13 & 10 & 6 & 12 & 11 & 10 & 12 & 10 & 15 & 11 \\
\hline $\mathrm{Cr}$ & 17 & 19 & 10 & 7 & 14 & 14 & 9 & 19 & 12 & 26 & 10 \\
\hline Sc & 10 & 7 & 7 & 9 & 8 & 5 & 9 & 15 & 13 & 14 & 11 \\
\hline $\mathrm{V}$ & 87 & 81 & 49 & 70 & 74 & 38 & 69 & 87 & 74 & 98 & 55 \\
\hline $\mathrm{Ba}$ & 383 & 514 & 314 & 377 & 489 & 371 & 325 & 346 & 366 & 371 & 423 \\
\hline $\mathrm{Rb}$ & 27 & 38 & 18 & 25 & 80 & 30 & 25 & 26 & 24 & 37 & 30 \\
\hline $\mathrm{Sr}$ & 744 & 505 & 486 & 790 & 450 & 477 & 767 & 576 & 802 & 528 & 480 \\
\hline $\mathrm{Zr}$ & 162 & 139 & 139 & 161 & 144 & 136 & 138 & 117 & 140 & 146 & 125 \\
\hline$Y$ & 16 & 14 & 11 & 16 & 14 & 9 & 8 & 11 & 10 & 14 & 10 \\
\hline $\mathrm{Nb}$ & 8 & 10 & 9 & 7 & 8 & 10 & 6 & 7 & 6 & 8 & 9 \\
\hline Ga & 19 & 19 & 22 & 21 & 16 & 19 & 20 & 20 & 23 & 22 & 21 \\
\hline $\mathrm{Cu}$ & 23 & 15 & 9 & 13 & 19 & 16 & 11 & 10 & 21 & 23 & 13 \\
\hline $\mathrm{Zn}$ & 70 & 60 & 60 & 65 & 62 & 55 & 52 & 55 & 53 & 48 & 61 \\
\hline $\mathrm{Pb}$ & 7 & 7 & 6 & 6 & 8 & 6 & 6 & 5 & 6 & 7 & 6 \\
\hline La & 20 & 25 & 21 & 23 & 13 & 11 & 12 & 35 & 31 & 18 & 15 \\
\hline $\mathrm{Ce}$ & 48 & 42 & 38 & 55 & 46 & 33 & 17 & 20 & 39 & 43 & 23 \\
\hline $\mathrm{Th}$ & 4 & 5 & 3 & 3 & 5 & 4 & 0 & 4 & 2 & 2 & 4 \\
\hline
\end{tabular}

* Total iron recalculated as FeO. 
APPENDIX A. XRF ANALYYZES CONTINUED

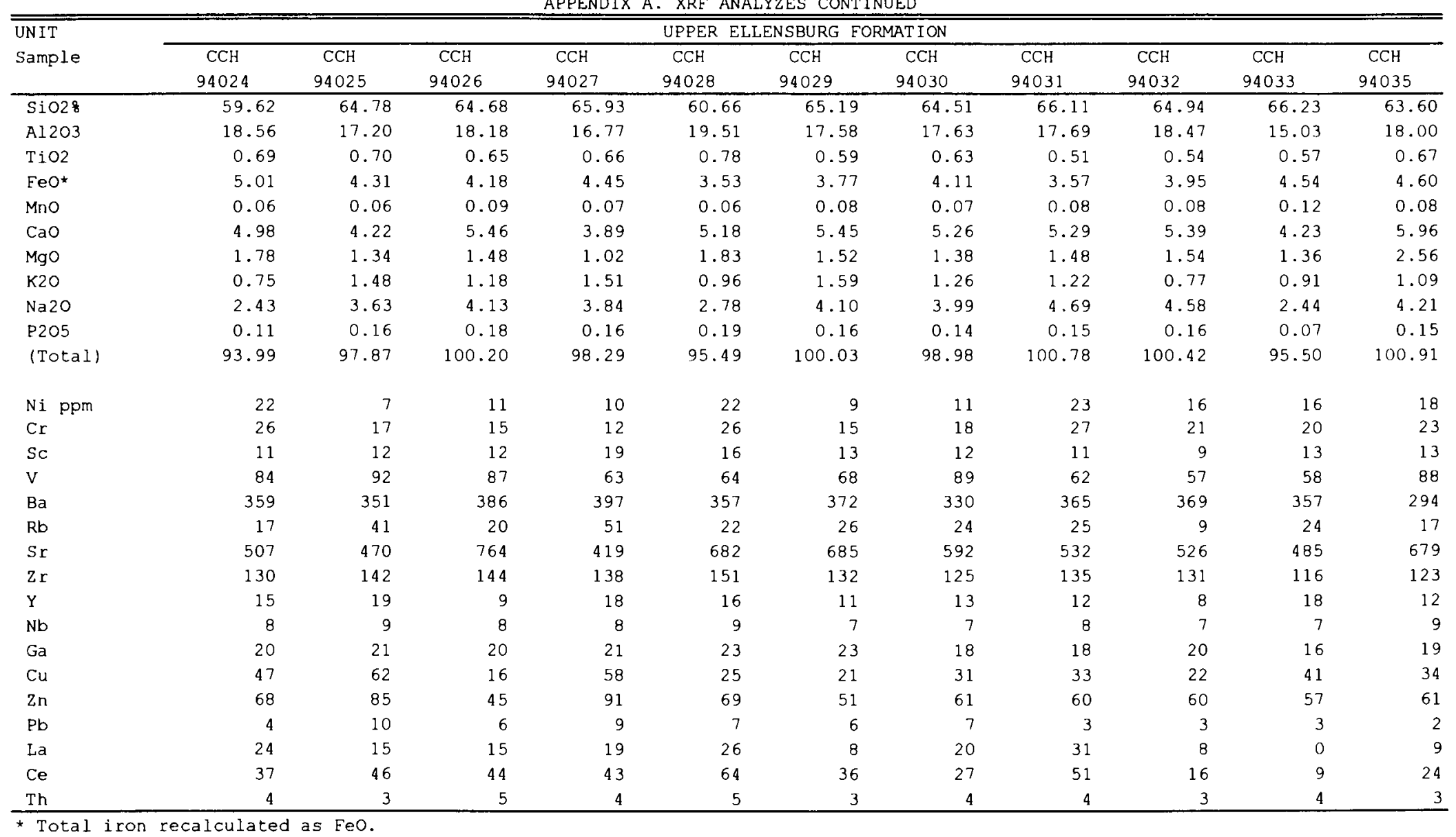


APPENDIX A. XRF ANALYZES CONTINUED

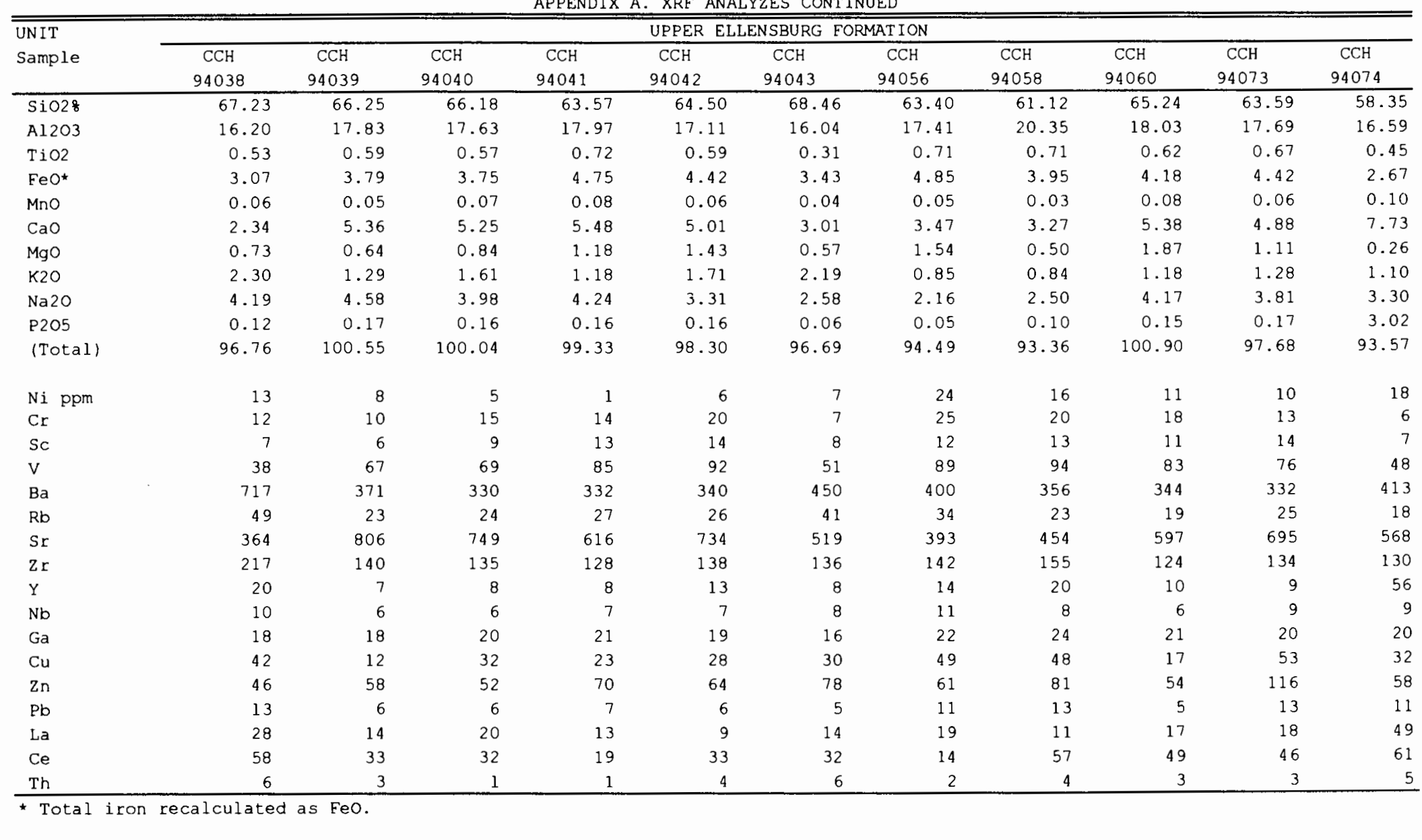


APPENDIX A. XRF ANALYZES CONTINUED

\begin{tabular}{|c|c|c|c|c|c|c|c|c|c|c|c|}
\hline \multirow{3}{*}{$\begin{array}{l}\text { UNIT } \\
\text { Sample }\end{array}$} & \multicolumn{11}{|c|}{ UPPER ELLENSBURG FORMATION } \\
\hline & $\mathrm{CCH}$ & $\mathrm{CCH}$ & $\mathrm{CCH}$ & $\mathrm{CCH}$ & $\mathrm{CCH}$ & $\mathrm{CCH}$ & $\mathrm{CCH}$ & $\mathrm{CCH}$ & $\mathrm{CCH}$ & $\mathrm{CCH}$ & $\mathrm{CCH}$ \\
\hline & 94078 & 94084 & 94085 & 94091 & 94092 & 94093 & 94094 & 94095 & 94096 & 94097 & 94099 \\
\hline $\mathrm{SiO} 2 \mathrm{z}$ & 64.38 & 63.60 & 62.90 & 60.88 & 63.42 & 64.32 & 66.30 & 65.20 & 61.24 & 62.13 & 62.22 \\
\hline $\mathrm{TiO} 2$ & 0.67 & 0.71 & 0.74 & 0.78 & 0.66 & 0.68 & 0.55 & 0.53 & 0.83 & 0.68 & 0.73 \\
\hline $\mathrm{FeO}^{\star}$ & 5.56 & 3.80 & 4.19 & 4.81 & 4.52 & 4.65 & 4.37 & 4.14 & 5.53 & 4.96 & 4.93 \\
\hline $\mathrm{MnO}$ & 0.08 & 0.10 & 0.08 & 0.09 & 0.07 & 0.06 & 0.06 & 0.07 & 0.09 & 0.19 & 0.08 \\
\hline $\mathrm{CaO}$ & 2.57 & 5.19 & 5.44 & 4.90 & 5.67 & 5.29 & 3.33 & 4.49 & 5.82 & 5.59 & 5.95 \\
\hline $\mathrm{K} 2 \mathrm{O}$ & 1.97 & 1.65 & 0.78 & 1.00 & 1.33 & 1.33 & 0.69 & 1.84 & 0.86 & 0.90 & 0.94 \\
\hline $\mathrm{Na} 2 \mathrm{O}$ & 2.11 & 4.02 & 4.20 & 3.27 & 4.23 & 4.28 & 1.72 & 3.57 & 4.12 & 4.01 & 4.12 \\
\hline P205 & 0.09 & 0.17 & 0.19 & 0.13 & 0.17 & 0.18 & 0.08 & 0.13 & 0.16 & 0.12 & 0.18 \\
\hline (Total) & 93.52 & 99.20 & 99.67 & 96.06 & 99.81 & 99.94 & 93.90 & 98.64 & 99.65 & 98.60 & 99.95 \\
\hline $\mathrm{Ni} \mathrm{ppm}$ & 10 & 17 & 21 & 21 & 12 & 16 & 18 & 13 & 21 & 20 & 10 \\
\hline $\mathrm{Cr}$ & 10 & 21 & 21 & 25 & 18 & 29 & 16 & 19 & 35 & 19 & 17 \\
\hline Sc & 19 & 12 & 12 & 15 & 15 & 20 & 11 & 11 & 17 & 17 & 19 \\
\hline $\mathrm{v}$ & 47 & 89 & 65 & 106 & 90 & 80 & 53 & 68 & 124 & 104 & 86 \\
\hline $\mathrm{Rb}$ & 85 & 23 & 8 & 22 & 21 & 22 & 22 & 26 & 13 & 11 & 15 \\
\hline Sr & 215 & 551 & 844 & 549 & 680 & 522 & 345 & 446 & 541 & 666 & 687 \\
\hline $\mathrm{Zr}$ & 311 & 147 & 145 & 141 & 135 & 140 & 124 & 137 & 147 & 128 & 135 \\
\hline$Y$ & 48 & 10 & 10 & 11 & 9 & 9 & 15 & 8 & 11 & 8 & 10 \\
\hline $\mathrm{Nb}$ & 18 & 10 & 10 & 10 & 8 & 9 & 9 & 11 & 10 & 7 & 8 \\
\hline $\mathrm{Ga}$ & 26 & 20 & 22 & 22 & 21 & 22 & 19 & 22 & 22 & 22 & 20 \\
\hline $\mathrm{Cu}$ & 34 & 32 & 39 & 35 & 21 & 34 & 48 & 17 & 34 & 36 & 28 \\
\hline $\mathrm{Zn}$ & 103 & 65 & 66 & 70 & 63 & 63 & 57 & 60 & 69 & 62 & 58 \\
\hline $\mathrm{Pb}$ & 8 & 5 & 8 & 6 & 2 & 5 & 8 & 7 & 5 & 6 & 5 \\
\hline $\mathrm{La}$ & 35 & 11 & 12 & 25 & 20 & 7 & 8 & 26 & 10 & 15 & 14 \\
\hline $\mathrm{Ce}$ & 45 & 39 & 36 & 49 & 28 & 22 & 24 & 21 & 40 & 28 & 22 \\
\hline $\mathrm{Th}$ & 9 & 2 & 5 & 5 & 2 & 2 & 4 & 3 & 5 & 4 & 4 \\
\hline
\end{tabular}


APPENDIX A. XRF ANALYZES CONTINUED

\begin{tabular}{|c|c|c|c|c|c|c|c|c|c|c|c|}
\hline \multirow{3}{*}{$\begin{array}{l}\text { UNIT } \\
\text { Sample }\end{array}$} & \multicolumn{11}{|c|}{ UPPER ELLENSBURG FORMAT ION } \\
\hline & $\mathrm{CCH}$ & $\mathrm{CCH}$ & $\mathrm{CCH}$ & $\mathrm{CCH}$ & $\mathrm{CCH}$ & $\mathrm{CCH}$ & $\mathrm{CCH}$ & $\mathrm{CCH}$ & $\mathrm{CCH}$ & $\mathrm{CCH}$ & $\mathrm{CCH}$ \\
\hline & 94103 & 94105 & 94106 & 94107 & 94108 & 94109 & 94110 & 94111 & 94113 & 94114 & 94115 \\
\hline $\mathrm{SiO} 28$ & 62.17 & 64.63 & 57.93 & 66.03 & 60.73 & 60.91 & 59.43 & 66.52 & 66.22 & 67.63 & 64.36 \\
\hline $\mathrm{TiO} 2$ & 0.72 & 0.63 & 0.53 & 0.51 & 0.87 & 0.87 & 0.72 & 0.57 & 0.51 & 0.45 & 0.65 \\
\hline $\mathrm{FeO}^{\star}$ & 5.51 & 4.28 & 3.71 & 3.37 & 5.25 & 5.51 & 3.61 & 3.99 & 3.73 & 3.38 & 4.15 \\
\hline MnO & 0.10 & 0.05 & 0.06 & 0.10 & 0.08 & 0.05 & 0.08 & 0.07 & 0.07 & 0.08 & 0.08 \\
\hline $\mathrm{CaO}$ & 5.14 & 5.06 & 10.75 & 3.26 & 5.90 & 5.06 & 4.90 & 5.12 & 5.02 & 4.90 & 5.47 \\
\hline $\mathrm{K} 2 \mathrm{O}$ & 1.08 & 1.96 & 0.98 & 1.92 & 0.63 & 0.95 & 0.73 & 1.38 & 1.23 & 1.15 & 1.43 \\
\hline $\mathrm{Na} 20$ & 3.83 & 3.86 & 4.03 & 2.51 & 4.29 & 3.63 & 2.42 & 4.63 & 4.41 & 4.76 & 4.67 \\
\hline P205 & 0.17 & 0.17 & 0.41 & 0.12 & 0.21 & 0.20 & 0.23 & 0.16 & 0.13 & 0.15 & 0.25 \\
\hline (Total) & 98.15 & 98.80 & 96.41 & 95.58 & 100.04 & 97.23 & 93.52 & 101.12 & 100.29 & 101.16 & 100.30 \\
\hline $\mathrm{Ni}$ ppm & 16 & 12 & 15 & 8 & 35 & 18 & 25 & 10 & 12 & 11 & 15 \\
\hline $\mathrm{Cr}$ & 22 & 31 & 19 & 5 & 59 & 25 & 33 & 14 & 15 & 10 & 16 \\
\hline Sc & 19 & 13 & 13 & 9 & 14 & 13 & 14 & 15 & 12 & 12 & 15 \\
\hline v & 98 & 76 & 82 & 37 & 106 & 106 & 248 & 60 & 61 & 46 & 72 \\
\hline $\mathrm{Rb}$ & 18 & 31 & 16 & 43 & 5 & 19 & 20 & 27 & 25 & 19 & 25 \\
\hline $\mathrm{Sr}$ & 696 & 604 & 644 & 552 & 559 & 859 & 601 & 536 & 574 & 525 & 1061 \\
\hline $2 r$ & 143 & 135 & 119 & 160 & 172 & 168 & 123 & 132 & 134 & 143 & 167 \\
\hline$Y$ & 12 & 11 & 22 & 13 & 8 & 12 & 13 & 11 & 9 & 8 & 9 \\
\hline $\mathrm{Nb}$ & 8 & 9 & 6 & 9 & 11 & 9 & 8 & 8 & 9 & 9 & 8 \\
\hline $\mathrm{Ga}$ & 20 & 18 & 19 & 21 & 23 & 23 & 21 & 20 & 20 & 19 & 19 \\
\hline $\mathrm{Cu}$ & 19 & 13 & 35 & 64 & 35 & 47 & 25 & 13 & 18 & 13 & 20 \\
\hline $\mathrm{Zn}$ & 65 & 52 & 60 & 50 & 78 & 88 & 87 & 52 & 53 & 54 & 53 \\
\hline $\mathrm{Pb}$ & 6 & 7 & 4 & 15 & 5 & 9 & 6 & 6 & 6 & 7 & 6 \\
\hline La & 18 & 15 & 30 & 24 & 18 & 18 & 23 & 11 & 18 & 11 & 29 \\
\hline $\mathrm{Ce}$ & 46 & 51 & 32 & 58 & 29 & 68 & 21 & 34 & 43 & 35 & 63 \\
\hline Th & 5 & 3 & 1 & 6 & 4 & 4 & 5 & 3 & 4 & 1 & 6 \\
\hline
\end{tabular}

* Total iron recalculated as Feo. 
APPENDIX A. XRF ANALYZES CONTINUED

\begin{tabular}{|c|c|c|c|c|c|c|c|c|c|c|c|}
\hline \multirow{3}{*}{$\begin{array}{l}\text { UNIT } \\
\text { Sample }\end{array}$} & \multicolumn{11}{|c|}{ UPPER ELLENSBURG FORMATION } \\
\hline & $\mathrm{CCH}$ & $\mathrm{CCH}$ & $\mathrm{CCH}$ & $\mathrm{CCH}$ & $\mathrm{CCH}$ & $\mathrm{CCH}$ & $\mathrm{CCH}$ & $\mathrm{CCH}$ & $\mathrm{CCH}$ & $\mathrm{CCH}$ & $\mathrm{CCH}$ \\
\hline & 94116 & 94117 & 94118 & 94119 & 94120 & 94122 & 94123 & 94124 & 94126 & 94127 & 94128 \\
\hline SiO28 & 59.29 & 64.80 & 65.99 & 62.83 & 62.97 & 64.49 & 63.40 & 65.28 & 64.25 & 63.76 & 53.00 \\
\hline Al203 & 18.40 & 17.19 & 17.53 & 17.88 & 18.04 & 17.06 & 16.86 & 17.63 & 17.24 & 17.99 & 21.88 \\
\hline TiO2 & 0.83 & 0.64 & 0.53 & 0.67 & 0.64 & 0.67 & 0.77 & 0.57 & 0.62 & 0.72 & 0.90 \\
\hline $\mathrm{FeO} \star$ & 6.49 & 4.58 & 3.79 & 4.87 & 4.69 & 4.24 & 5.01 & 3.94 & 4.47 & 4.70 & 5.61 \\
\hline $\mathrm{MnO}$ & 0.10 & 0.08 & 0.07 & 0.09 & 0.10 & 0.05 & 0.08 & 0.06 & 0.07 & 0.09 & 0.06 \\
\hline $\mathrm{CaO}$ & 6.33 & 5.40 & 4.98 & 5.82 & 5.81 & 5.14 & 5.44 & 5.21 & 5.47 & 5.31 & 3.92 \\
\hline $\mathrm{MgO}$ & 2.31 & 1.84 & 1.21 & 1.45 & 1.60 & 1.31 & 2.48 & 1.23 & 1.39 & 1.23 & 1.78 \\
\hline $\mathrm{K} 2 \mathrm{O}$ & 0.88 & 1.63 & 1.34 & 1.15 & 1.33 & 2.03 & 1.55 & 1.19 & 1.86 & 1.26 & 0.49 \\
\hline $\mathrm{Na} 2 \mathrm{O}$ & 3.39 & 3.90 & 4.54 & 4.01 & 3.75 & 3.99 & 4.18 & 4.60 & 3.65 & 3.95 & 1.07 \\
\hline $\mathrm{P} 205$ & 0.15 & 0.16 & 0.15 & 0.14 & 0.14 & 0.18 & 0.19 & 0.16 & 0.16 & 0.16 & 0.15 \\
\hline (Total) & 98.16 & 100.21 & 100.13 & 98.91 & 99.07 & 99.15 & 99.96 & 99.87 & 99.17 & 99.17 & 88.86 \\
\hline $\mathrm{Ni} \mathrm{ppm}$ & 15 & 12 & 5 & 14 & 14 & 15 & 25 & 8 & 12 & 10 & 70 \\
\hline $\mathrm{Cr}$ & 28 & 20 & 10 & 24 & 21 & 22 & 37 & 10 & 20 & 19 & 32 \\
\hline Sc & 18 & 21 & 15 & 16 & 16 & 13 & 12 & 11 & 13 & 11 & 15 \\
\hline v & 119 & 75 & 75 & 82 & 98 & 80 & 103 & 65 & 87 & 77 & 94 \\
\hline $\mathrm{Ba}$ & 246 & 361 & 371 & 350 & 354 & 344 & 355 & 380 & 320 & 351 & 630 \\
\hline $\mathrm{Rb}$ & 18 & 34 & 19 & 23 & 22 & 31 & 30 & 20 & 25 & 25 & 14 \\
\hline$S r$ & 611 & 480 & 684 & 547 & 594 & 565 & 501 & 550 & 595 & 727 & 423 \\
\hline $\mathrm{Zr}$ & 122 & 129 & 129 & 124 & 120 & 137 & 151 & 132 & 134 & 142 & 163 \\
\hline$Y$ & 14 & 11 & 9 & 12 & 11 & 10 & 12 & 10 & 10 & 11 & 22 \\
\hline $\mathrm{Nb}$ & 8 & 9 & 7 & 9 & 8 & 8 & 11 & 9 & 8 & 8 & 12 \\
\hline $\mathrm{Ga}$ & 20 & 23 & 20 & 20 & 22 & 22 & 21 & 21 & 18 & 21 & 30 \\
\hline $\mathrm{Cu}$ & 73 & 6 & 13 & 30 & 27 & 14 & 27 & 23 & 9 & 28 & 61 \\
\hline $\mathrm{Zn}$ & 81 & 50 & 50 & 57 & 63 & 58 & 66 & 56 & 55 & 76 & 64 \\
\hline $\mathrm{Pb}$ & 4 & 2 & 7 & 6 & 4 & 3 & 4 & 6 & 3 & 8 & 8 \\
\hline La & 13 & 23 & 15 & 20 & 6 & 14 & 11 & 40 & 11 & 25 & 13 \\
\hline $\mathrm{Ce}$ & 23 & 39 & 41 & 35 & 41 & 28 & 25 & 38 & 25 & 54 & 35 \\
\hline $\mathrm{Th}$ & 1 & 5 & 3 & 4 & 3 & 0 & 7 & 1 & 3 & 4 & 4 \\
\hline
\end{tabular}

* Total iron recalculated as Feo. 
APPENDIX A. XRF ANALYZES CONTINUED

\begin{tabular}{|c|c|c|c|c|c|c|c|c|c|c|c|}
\hline \multirow{3}{*}{$\begin{array}{l}\text { UNIT } \\
\text { Sample }\end{array}$} & \multirow{2}{*}{\multicolumn{2}{|c|}{$\begin{array}{lr}\text { UP. ELL. } & \text { FORM. } \\
\mathrm{CCH} & \mathrm{CCH}\end{array}$}} & \multicolumn{9}{|c|}{ LOWER ELLENSBURG FORMATION } \\
\hline & & & $\mathrm{CCH}$ & $\mathrm{CCH}$ & $\mathrm{CCH}$ & $\mathrm{CCH}$ & $\mathrm{CCH}$ & $\mathrm{CCH}$ & $\mathrm{CCH}$ & $\mathrm{CCH}$ & $\mathrm{CCH}$ \\
\hline & 94129 & 94130 & 94011 & 94061 & 94062 & 94063 & 94064 & 94065 & 94066 & 94067 & 94070 \\
\hline SiO28 & 64.14 & 62.57 & 67.20 & 60.99 & 64.99 & 62.77 & 58.66 & 66.04 & 56.53 & 59.55 & 59.67 \\
\hline $\mathrm{A} 1203$ & 17.41 & 18.20 & 13.32 & 19.71 & 17.19 & 18.22 & 17.87 & 17.93 & 21.06 & 17.02 & 15.06 \\
\hline TiO2 & 0.60 & 0.63 & 0.37 & 1.12 & 0.92 & 1.19 & 1.33 & 0.28 & 1.11 & 1.02 & 1.24 \\
\hline $\mathrm{EeO}^{*}$ & 4.30 & 4.45 & 4.11 & 3.21 & 3.57 & 3.67 & 8.05 & 3.51 & 6.83 & 5.96 & 6.70 \\
\hline $\mathrm{MnO}$ & 0.08 & 0.06 & 0.11 & 0.04 & 0.10 & 0.09 & 0.20 & 0.07 & 0.04 & 0.05 & 0.08 \\
\hline $\mathrm{CaO}$ & 5.54 & 4.66 & 2.69 & 5.46 & 4.95 & 4.57 & 4.16 & 1.30 & 2.07 & 3.64 & 3.75 \\
\hline $\mathrm{MgO}$ & 1.91 & 1.01 & 1.06 & 1.20 & 2.06 & 1.89 & 0.76 & 0.02 & 0.48 & 0.86 & 1.88 \\
\hline $\mathrm{K} 2 \mathrm{O}$ & 1.39 & 0.95 & 2.29 & 0.91 & 1.95 & 1.46 & 1.26 & 2.62 & 0.65 & 1.05 & 1.15 \\
\hline $\mathrm{Na} 2 \mathrm{O}$ & 4.30 & 3.97 & 2.17 & 3.42 & 3.33 & 2.98 & 2.53 & 1.66 & 1.59 & 2.25 & 1.86 \\
\hline P205 & 0.17 & 0.13 & 0.05 & 0.26 & 0.10 & 0.08 & 0.17 & 0.02 & 0.09 & 0.09 & 0.25 \\
\hline (Total) & 99.84 & 96.63 & 93.36 & 96.32 & 99.16 & 96.91 & 94.99 & 93.45 & 90.44 & 91.49 & 91.65 \\
\hline $\mathrm{Ni}$ ppm & 9 & 11 & 6 & 8 & 3 & 5 & 7 & 11 & 13 & 6 & 9 \\
\hline $\mathrm{Cr}$ & 18 & 16 & 6 & 10 & 5 & 13 & 16 & 5 & 14 & 12 & 17 \\
\hline $\mathrm{Sc}$ & 16 & 10 & 20 & 24 & 19 & 24 & 26 & 18 & 24 & 26 & 25 \\
\hline v & 82 & 63 & 30 & 160 & 95 & 139 & 111 & 13 & 84 & 75 & 82 \\
\hline $\mathrm{Ba}$ & 345 & 344 & 481 & 637 & 615 & 595 & 511 & 679 & 798 & 493 & 547 \\
\hline $\mathrm{Rb}$ & 28 & 27 & 57 & 28 & 71 & 51 & 52 & 72 & 30 & 40 & 72 \\
\hline $\mathrm{Sr}$ & 623 & 544 & 133 & 379 & 327 & 330 & 277 & 113 & 193 & 257 & 294 \\
\hline $\mathrm{Zr}$ & 134 & 135 & 287 & 157 & 136 & 134 & 177 & 213 & 238 & 166 & 228 \\
\hline$Y$ & 11 & 13 & 47 & 36 & 31 & 14 & 64 & 29 & 72 & 28 & 64 \\
\hline $\mathrm{Nb}$ & 9 & 9 & 17 & 9 & 9 & 7 & 11 & 14 & 16 & 11 & 15 \\
\hline $\mathrm{Ga}$ & 18 & 21 & 19 & 20 & 18 & 18 & 24 & 28 & 27 & 20 & 22 \\
\hline $\mathrm{Cu}$ & 13 & 33 & 20 & 36 & 9 & 24 & 38 & 14 & 56 & 38 & 43 \\
\hline $\mathrm{Zn}$ & 56 & 75 & 98 & 43 & 50 & 63 & 105 & 77 & 134 & 94 & 85 \\
\hline $\mathrm{Pb}$ & 5 & 8 & 8 & 11 & 5 & 6 & 8 & 18 & 11 & 9 & 8 \\
\hline $\mathrm{La}$ & 4 & 16 & 27 & 36 & 18 & 10 & 27 & 19 & 42 & 32 & 33 \\
\hline $\mathrm{Ce}$ & 48 & 47 & 67 & 76 & 19 & 34 & 55 & 44 & 70 & 37 & 60 \\
\hline Th & 2 & 2 & 7 & 9 & 11 & 7 & 8 & 7 & 10 & 4 & 5 \\
\hline
\end{tabular}

* Total iron recalculated as FeO. 
APPENDIX A. XRF ANALYZES CONT INUED

\begin{tabular}{|c|c|c|c|c|c|c|c|c|c|c|c|}
\hline \multirow{3}{*}{$\begin{array}{l}\text { UNIT } \\
\text { Sample }\end{array}$} & \multicolumn{11}{|c|}{ LOWER ELLENSBURG FORMATION } \\
\hline & $\mathrm{CCH}$ & $\mathrm{CCH}$ & $\mathrm{CCH}$ & $\mathrm{CCH}$ & $\mathrm{CCH}$ & $\mathrm{CCH}$ & PHA & PHA & PHA & PHA & PHA \\
\hline & 94071 & 94077 & 94086 & 94087 & 94100 & 94101 & 93107 & 93108 & 93119 & 93120 & 93121 \\
\hline SiO28 & 62.81 & 70.87 & 67.91 & 67.55 & 61.35 & 63.73 & 71.99 & 73.73 & 59.93 & 65.18 & 74.38 \\
\hline TiO2 & 0.84 & 0.24 & 0.47 & 0.41 & 0.85 & 0.85 & 0.36 & 0.18 & 1.12 & 1.11 & 0.17 \\
\hline $\mathrm{FeO}^{*}$ & 5.43 & 2.38 & 3.72 & 3.99 & 6.89 & 5.48 & 3.37 & 2.03 & 8.29 & 6.80 & 2.01 \\
\hline Mno & 0.10 & 0.03 & 0.16 & 0.04 & 0.04 & 0.04 & 0.10 & 0.03 & 0.18 & 0.08 & 0.04 \\
\hline $\mathrm{CaO}$ & 3.11 & 1.86 & 1.34 & 1.59 & 2.69 & 3.10 & 2.58 & 1.79 & 6.09 & 3.58 & 1.91 \\
\hline $\mathrm{K} 2 \mathrm{O}$ & 2.03 & 2.81 & 3.27 & 3.02 & 1.31 & 1.58 & 2.96 & 3.38 & 1.19 & 1.15 & 3.20 \\
\hline $\mathrm{Na} 2 \mathrm{O}$ & 1.96 & 3.51 & 2.48 & 2.56 & 2.19 & 2.33 & 3.75 & 4.10 & 3.92 & 2.96 & 4.01 \\
\hline $\mathrm{P} 205$ & 0.18 & 0.05 & 0.02 & 0.02 & 0.05 & 0.05 & 0.06 & 0.02 & 0.36 & 0.12 & 0.08 \\
\hline (Total) & 92.24 & 95.39 & 94.97 & 94.61 & 93.60 & 94.97 & 100.00 & 100.00 & 100.00 & 100.00 & 100.00 \\
\hline $\mathrm{Ni}$ ppm & 9 & 8 & 10 & 9 & 10 & 7 & 7 & 9 & 0 & 7 & 9 \\
\hline $\mathrm{Cr}$ & 11 & 1 & 7 & 4 & 13 & 6 & 6 & 1 & 8 & 2 & 3 \\
\hline $\mathrm{Sc}$ & 19 & 7 & 12 & 15 & 28 & 26 & 11 & 6 & 28 & 27 & 4 \\
\hline$v$ & 47 & 17 & 33 & 23 & 78 & 81 & 46 & 8 & 108 & 55 & 17 \\
\hline $\mathrm{Rb}$ & 73 & 101 & 110 & 106 & 52 & 51 & 66 & 104 & 30 & 47 & 101 \\
\hline $\mathrm{Sr}$ & 212 & 124 & 107 & 131 & 210 & 232 & 135 & 121 & 308 & 233 & 118 \\
\hline $\mathrm{zr}$ & 302 & 131 & 186 & 186 & 218 & 163 & 136 & 127 & 156 & 191 & 123 \\
\hline$Y$ & 65 & 23 & 35 & 35 & 35 & 28 & 32 & 22 & 35 & 59 & 23 \\
\hline $\mathrm{Nb}$ & 19 & 12 & 15 & 14 & 13 & 11 & 8 & 10 & 8 & 11 & 10 \\
\hline $\mathrm{Ga}$ & 18 & 15 & 21 & 19 & 22 & 24 & 16 & 18 & 19 & 21 & 18 \\
\hline $\mathrm{Cu}$ & 39 & 11 & 18 & 15 & 49 & 22 & 15 & 12 & 26 & 25 & 11 \\
\hline $\mathrm{Zn}$ & 86 & 39 & 65 & 68 & 77 & 76 & 63 & 39 & 98 & 96 & 31 \\
\hline $\mathrm{Pb}$ & 12 & 10 & 11 & 11 & 12 & 8 & 8 & 11 & 5 & 7 & 8 \\
\hline La & 30 & 36 & 30 & 49 & 20 & 17 & 15 & 24 & 3 & 19 & 32 \\
\hline $\mathrm{Ce}$ & 65 & 52 & 52 & 49 & 61 & 37 & 59 & 65 & 45 & 40 & 53 \\
\hline Th & 8 & 11 & 13 & 13 & 9 & 7 & 6 & 13 & 4 & 6 & 14 \\
\hline
\end{tabular}

* Total iron recalculated as Feo. 
APPENDIX A. XRF ANALYZES CONTINUED

\begin{tabular}{|c|c|c|c|c|c|c|c|c|c|}
\hline \multirow{3}{*}{$\begin{array}{l}\text { UNIT } \\
\text { Sample }\end{array}$} & \multirow{2}{*}{$\frac{\text { L. ELL. EM. }}{\text { PHA }}$} & \multicolumn{8}{|c|}{ COLUMBIA RIVER BASALT } \\
\hline & & $\mathrm{CCH}$ & $\mathrm{CCH}$ & $\mathrm{CCH}$ & $\mathrm{CCH}$ & $\mathrm{CCH}$ & $\mathrm{CCH}$ & $\mathrm{CCH}$ & $\mathrm{CCH}$ \\
\hline & 94105 & 94049 & 94068 & 94069 & 94072 & 94088 & 94098 & 94104 & 94112 \\
\hline $\mathrm{SiO} 28$ & 65.48 & 55.97 & 55.24 & 51.23 & 55.54 & 55.15 & 54.48 & 54.74 & 55.06 \\
\hline Al 203 & 13.73 & 13.93 & 14.46 & 18.83 & 13.94 & 14.33 & 13.93 & 14.43 & 14.37 \\
\hline TiO2 & 0.47 & 1.98 & 1.83 & 1.30 & 1.98 & 1.83 & 1.79 & 1.73 & 1.83 \\
\hline $\mathrm{FeO}^{\star}$ & 4.80 & 11.09 & 10.36 & 8.54 & 11.01 & 10.42 & 11.30 & 10.87 & 10.93 \\
\hline $\mathrm{MnO}$ & 0.05 & 0.17 & 0.20 & 0.19 & 0.19 & 0.20 & 0.20 & 0.21 & 0.20 \\
\hline $\mathrm{CaO}$ & 1.41 & 7.40 & 8.37 & 9.61 & 7.56 & 8.31 & 8.23 & 8.78 & 8.38 \\
\hline MgO & 1.05 & 3.88 & 4.55 & 5.52 & 4.00 & 4.55 & 4.56 & 4.64 & 4.44 \\
\hline $\mathrm{K} 2 \mathrm{O}$ & 2.67 & 1.53 & 1.42 & 1.00 & 1.53 & 1.38 & 1.45 & 1.32 & 1.44 \\
\hline $\mathrm{Na} 2 \mathrm{O}$ & 1.01 & 3.38 & 3.03 & 3.02 & 3.30 & 3.08 & 3.04 & 3.11 & 3.11 \\
\hline P2O5 & 0.03 & 0.33 & 0.35 & 0.28 & 0.33 & 0.37 & 0.35 & 0.30 & 0.37 \\
\hline (Total) & 90.69 & 99.66 & 99.80 & 99.53 & 99.38 & 99.62 & 99.33 & 100.13 & 100.13 \\
\hline $\mathrm{Ni} \mathrm{ppm}$ & 8 & 7 & 5 & 27 & 7 & 7 & 1 & 5 & 4 \\
\hline $\mathrm{Cr}$ & 0 & 19 & 39 & 54 & 17 & 37 & 38 & 44 & 33 \\
\hline Sc & 10 & 36 & 36 & 33 & 35 & 38 & 36 & 44 & 38 \\
\hline v & 11 & 361 & 326 & 265 & 346 & 294 & 293 & 322 & 308 \\
\hline $\mathrm{Ba}$ & 837 & 598 & 548 & 284 & 598 & 566 & 527 & 497 & 581 \\
\hline $\mathrm{Rb}$ & 110 & 41 & 34 & 31 & 37 & 34 & 34 & 31 & 34 \\
\hline $\mathrm{Sr}$ & 120 & 306 & 308 & 283 & 303 & 306 & 307 & 318 & 311 \\
\hline $\mathrm{Zr}$ & 399 & 165 & 160 & 118 & 162 & 160 & 162 & 155 & 164 \\
\hline$Y$ & 40 & 34 & 35 & 29 & 34 & 36 & 34 & 35 & 37 \\
\hline $\mathrm{Nb}$ & 28 & 13 & 15 & 9 & 15 & 16 & 14 & 13 & 14 \\
\hline $\mathrm{Ga}$ & 26 & 22 & 22 & 20 & 22 & 23 & 21 & 19 & 21 \\
\hline $\mathrm{Cu}$ & 8 & 33 & 17 & 45 & 25 & 19 & 19 & 20 & 22 \\
\hline $\mathrm{Zn}$ & 115 & 124 & 117 & 86 & 115 & 113 & 110 & 112 & 117 \\
\hline $\mathrm{Pb}$ & 23 & 7 & 8 & 2 & 6 & 4 & 7 & 4 & 8 \\
\hline $\mathrm{La}$ & 55 & 36 & 29 & 13 & 6 & 22 & 13 & 19 & 19 \\
\hline $\mathrm{Ce}$ & 112 & 51 & 44 & 39 & 48 & 47 & 39 & 47 & 37 \\
\hline Th & 22 & 3 & 4 & 6 & 5 & 3 & 4 & 0 & 5 \\
\hline
\end{tabular}


APPENDIX A. XRF ANALYZES CONTINUED

\begin{tabular}{|c|c|c|c|c|c|c|c|c|c|}
\hline \multirow{3}{*}{$\begin{array}{l}\text { UNIT } \\
\text { Sample }\end{array}$} & \multicolumn{3}{|c|}{ BUMPING RIVER TUFF } & \multicolumn{6}{|c|}{ FIFES PEAKS FORMAT ION } \\
\hline & $\mathrm{CCH}$ & $\mathrm{CCH}$ & $\mathrm{CCH}$ & $\mathrm{CCH}$ & $\mathrm{CCH}$ & $\mathrm{CCH}$ & $\mathrm{CCH}$ & $\mathrm{CCH}$ & $\mathrm{CCH}$ \\
\hline & 94013 & 94014 & 94015 & 94003 & 94004 & 94005 & 94047 & 94055 & 94102 \\
\hline $\mathrm{SiO} 28$ & 74.76 & 74.30 & 73.90 & 62.00 & 63.05 & 61.47 & 74.33 & 59.96 & 64.25 \\
\hline Al 203 & 13.27 & 13.40 & 10.99 & 15.96 & 16.74 & 17.17 & 14.99 & 17.54 & 17.29 \\
\hline TiO2 & 0.14 & 0.17 & 0.13 & 0.85 & 0.82 & 0.86 & 0.18 & 1.00 & 0.83 \\
\hline $\mathrm{FeO}^{*}$ & 1.64 & 2.20 & 0.59 & 6.69 & 4.98 & 4.81 & 1.65 & 7.85 & 5.62 \\
\hline Mno & 0.02 & 0.05 & 0.01 & 0.09 & 0.12 & 0.10 & 0.02 & 0.15 & 0.06 \\
\hline $\mathrm{CaO}$ & 1.21 & 1.05 & 2.22 & 4.60 & 5.10 & 4.59 & 1.57 & 5.91 & 4.77 \\
\hline MgO & 0.00 & 0.00 & 0.33 & 0.84 & 2.10 & 1.54 & 0.00 & 2.21 & 0.45 \\
\hline $\mathrm{K} 2 \mathrm{O}$ & 2.77 & 2.74 & 3.45 & 2.36 & 2.37 & 2.13 & 3.21 & 1.78 & 2.58 \\
\hline $\mathrm{Na} 2 \mathrm{O}$ & 4.41 & 2.74 & 0.70 & 3.49 & 3.48 & 3.24 & 3.92 & 3.87 & 3.83 \\
\hline P205 & 0.03 & 0.03 & 0.02 & 0.18 & 0.15 & 0.12 & 0.04 & 0.25 & 0.16 \\
\hline (Total) & 98.25 & 96.68 & 92.34 & 97.06 & 98.91 & 96.02 & 99.91 & 100.51 & 99.83 \\
\hline $\mathrm{Ni}$ ppm & 9 & 7 & 11 & 2 & 7 & 10 & 8 & 6 & 6 \\
\hline $\mathrm{Cr}$ & 3 & 2 & 2 & 3 & 19 & 14 & 2 & 12 & 10 \\
\hline Sc & 6 & 8 & 3 & 12 & 13 & 16 & 2 & 20 & 22 \\
\hline $\mathrm{v}$ & 3 & 16 & 9 & 111 & 113 & 98 & 3 & 116 & 132 \\
\hline $\mathrm{Ba}$ & 664 & 661 & 840 & 591 & 671 & 637 & 819 & 458 & 737 \\
\hline $\mathrm{Rb}$ & 66 & 79 & 91 & 67 & 73 & 67 & 107 & 53 & 90 \\
\hline sr & 93 & 124 & 492 & 298 & 295 & 301 & 125 & 309 & 257 \\
\hline $2 \mathrm{r}$ & 133 & 142 & 131 & 137 & 154 & 157 & 129 & 166 & 171 \\
\hline$Y$ & 36 & 30 & 22 & 24 & 30 & 33 & 28 & 29 & 34 \\
\hline $\mathrm{Nb}$ & 10 & 9 & 7 & 8 & 9 & 9 & 13 & 10 & 12 \\
\hline $\mathrm{Ga}$ & 18 & 17 & 17 & 17 & 15 & 17 & 17 & 21 & 14 \\
\hline $\mathrm{Cu}$ & 9 & 9 & 15 & 19 & 17 & 22 & 13 & 74 & 29 \\
\hline $2 n$ & 46 & 38 & 18 & 57 & 69 & 68 & 40 & 77 & 55 \\
\hline $\mathrm{Pb}$ & 9 & 8 & 2 & 11 & 8 & 12 & 12 & 3 & 8 \\
\hline La & 21 & 33 & 20 & 27 & 35 & 34 & 20 & 21 & 32 \\
\hline $\mathrm{Ce}$ & 55 & 47 & 52 & 41 & 55 & 64 & 46 & 61 & 63 \\
\hline Th & 7 & 8 & 7 & 11 & 10 & 12 & 13 & 6 & 13 \\
\hline
\end{tabular}

* Total iron recalculated as FeO. 
APPENDIX A. XRF ANALYZES CONT INUED

\begin{tabular}{|c|c|c|c|c|c|}
\hline \multirow{3}{*}{$\begin{array}{l}\text { UNIT } \\
\text { Sample }\end{array}$} & \multicolumn{5}{|c|}{ PRE-ELLENSBURG INTRUSIONS } \\
\hline & $\mathrm{CCH}$ & $\mathrm{CCH}$ & $\mathrm{CCH}$ & $\mathrm{CCH}$ & $\mathrm{CCH}$ \\
\hline & 94016 & 94017 & 94018 & 94053 & 94054 \\
\hline SiO28 & 59.55 & 73.28 & 59.13 & 67.13 & 58.73 \\
\hline Al 203 & 16.71 & 14.29 & 16.86 & 16.38 & 18.14 \\
\hline TiO2 & 0.88 & 0.25 & 0.86 & 0.83 & 0.88 \\
\hline $\mathrm{FeO}^{*}$ & 7.13 & 2.97 & 6.99 & 4.94 & 5.11 \\
\hline $\mathrm{MnO}$ & 0.14 & 0.11 & 0.14 & 0.08 & 0.13 \\
\hline $\mathrm{CaO}$ & 6.22 & 1.63 & 6.07 & 3.43 & 7.03 \\
\hline $\mathrm{MgO}$ & 3.02 & 0.04 & 2.89 & 0.71 & 2.20 \\
\hline $\mathrm{K} 2 \mathrm{O}$ & 1.49 & 2.17 & 1.64 & 2.43 & 1.03 \\
\hline $\mathrm{Na} 2 \mathrm{O}$ & 3.66 & 4.64 & 3.75 & 2.82 & 3.75 \\
\hline P2O5 & 0.17 & 0.10 & 0.17 & 0.20 & 0.21 \\
\hline (Total) & 98.97 & 99.48 & 98.50 & 98.95 & 97.21 \\
\hline $\mathrm{Ni}$ ppin & 11 & 9 & 13 & 6 & 7 \\
\hline $\mathrm{Cr}$ & 31 & 3 & 26 & 10 & 18 \\
\hline Sc & 20 & 13 & 23 & 16 & 19 \\
\hline $\mathrm{V}$ & 150 & 7 & 141 & 89 & 138 \\
\hline $\mathrm{Ba}$ & 382 & 693 & 454 & 651 & 443 \\
\hline $\mathrm{Rb}$ & 47 & 60 & 44 & 64 & 35 \\
\hline Sr & 227 & 150 & 249 & 214 & 300 \\
\hline $2 r$ & 166 & 185 & 165 & 165 & 165 \\
\hline$Y$ & 30 & 30 & 30 & 21 & 28 \\
\hline $\mathrm{Nb}$ & 9 & 11 & 9 & 9 & 9 \\
\hline $\mathrm{Ga}$ & 17 & 18 & 19 & 21 & 19 \\
\hline $\mathrm{Cu}$ & 32 & 11 & 54 & 8 & 31 \\
\hline $2 n$ & 69 & 77 & 84 & 99 & 99 \\
\hline $\mathrm{Pb}$ & 6 & 6 & 10 & 9 & 4 \\
\hline La & 28 & 23 & 18 & 23 & 18 \\
\hline $\mathrm{Ce}$ & 27 & 50 & 29 & 39 & 75 \\
\hline Th & 9 & 7 & 4 & 3 & 9 \\
\hline
\end{tabular}


APPENDIX B. INAA ANALYZES

\begin{tabular}{|c|c|c|c|c|c|c|c|c|c|c|}
\hline \multirow{3}{*}{$\begin{array}{l}\text { UNIT } \\
\text { Sample }\end{array}$} & \multicolumn{8}{|c|}{ DACITE OF OLD SCAB MOUNTAIN } & \multicolumn{2}{|c|}{ OTHER DACITES } \\
\hline & $\mathrm{CCH}$ & & $\mathrm{CCH}$ & & $\mathrm{CCH}$ & & $\mathrm{CCH}$ & & $\overline{\text { PHA }}$ & \\
\hline & 94019 & \& error & 94020 & \& error & 94079 & $\&$ error & 94081 & \& error & 91 & gerr \\
\hline $\mathrm{Na} 8$ & 2.93 & 0.24 & 2.68 & 0.24 & 2.70 & 0.28 & 2.60 & 0.27 & 3.21 & 0.21 \\
\hline $\mathrm{K} 8$ & 1.32 & 21.50 & 1.47 & 19.18 & 1.66 & $<0.01$ & 2.30 & 21.01 & 1.72 & 22.05 \\
\hline $\mathrm{Fe} 8$ & 2.80 & 1.02 & 2.47 & 1.21 & 2.68 & 1.04 & 2.71 & 1.04 & 2.90 & 0.85 \\
\hline $\mathrm{Sc}$ & 7.49 & 0.90 & 6.47 & 0.90 & 7.05 & 0.99 & 7.25 & 0.88 & 7.69 & 1.99 \\
\hline $\mathrm{Cr}$ & 12.80 & 13.38 & 19.75 & $<0.01$ & 20.78 & 18.73 & 17.24 & 17.65 & 19.73 & 10.94 \\
\hline Co & 19.12 & 2.07 & 15.75 & 2.47 & 14.81 & 1.81 & 12.67 & 2.38 & 9.56 & 2.47 \\
\hline $2 n$ & 59.04 & 34.26 & 51.08 & 39.54 & 65.44 & 28.03 & 55.94 & 32.76 & 62.10 & 27.98 \\
\hline Ga & ----- & ---- & ---- & ---- & $-\ldots$ & $-\cdots$ & $-\ldots$ & ---- & 20.04 & $<0.01$ \\
\hline As & 25.52 & $<0.01$ & 2.01 & 49.10 & 30.77 & $<0.01$ & ---- &.--- & 32.02 & $<0.01$ \\
\hline $\mathrm{Br}$ & ---- & ---- & ---- & $\ldots-$ & ---- & ---- & -... & $\ldots$. & 0.19 & $<0.01$ \\
\hline $\mathrm{Rb}$ & ---- & ---- & 45.38 & 16.81 & 28.17 & 24.11 & 36.72 & 21.53 & 39.42 & 20.32 \\
\hline $\mathrm{Sr}$ & 592.60 & 11.66 & 580.64 & 12.96 & 583.52 & 12.26 & 586.20 & 11.08 & 658.32 & 8.32 \\
\hline $2 r$ & 284.98 & 26.26 & 358.09 & $<0.01$ & 295.19 & $<0.01$ & $\ldots$ & ---- & 108.63 & 34.79 \\
\hline $\mathrm{Sb}$ & ---- & $\ldots$ & 0.55 & $<0.01$ & $-\ldots$ & $\ldots$. & -..- & ----- & ---- & ---- \\
\hline Cs & 1.39 & $<0.01$ & 1.42 & 18.65 & 1.83 & $<0.01$ & 1.48 & 15.42 & 1.09 & 17.68 \\
\hline $\mathrm{Ba}$ & 458.31 & 8.51 & 399.12 & 10.00 & 476.07 & 7.59 & 478.57 & 8.08 & 457.24 & 6.49 \\
\hline La & 15.72 & 6.38 & 17.11 & 3.89 & 17.20 & 4.30 & 16.93 & 5.22 & 20.60 & 2.29 \\
\hline $\mathrm{Ce}$ & 30.28 & 2.69 & 34.47 & 2.60 & 32.90 & 2.37 & 32.20 & 2.26 & 39.93 & 1.66 \\
\hline $\mathrm{Nd}$ & 17.11 & $<0.01$ & ----- & ----- & $-\cdots$ & ---- & ----- & ----- & ----- & ----- \\
\hline Sm & 2.81 & 2.89 & 3.01 & 1.82 & 2.85 & 2.59 & 3.06 & 2.95 & 3.89 & 1.03 \\
\hline $\mathrm{Eu}$ & 1.01 & 10.70 & 0.97 & 3.67 & 0.97 & 3.28 & 0.94 & 6.79 & 1.13 & 7.31 \\
\hline $\mathrm{Tb}$ & 0.44 & 15.68 & 1.49 & $<0.01$ & --- & ---- & 0.53 & $<0.01$ & 0.46 & 9.14 \\
\hline $\mathrm{Yb}$ & 1.48 & 18.45 & 1.16 & $<0.01$ & 1.49 & 15.63 & 1.30 & 18.79 & 1.26 & 14.15 \\
\hline Lu & 0.16 & 14.39 & 0.15 & 13.76 & 0.19 & 15.58 & 0.14 & 17.54 & 0.19 & 12.34 \\
\hline $\mathrm{Hf}$ & 3.39 & 4.47 & 3.65 & 4.98 & 3.53 & 4.64 & 3.51 & 4.91 & 3.48 & 3.44 \\
\hline $\mathrm{Ta}$ & 1.15 & 11.11 & 0.75 & 18.61 & 0.73 & $<0.01$ & 0.69 & $<0.01$ & 0.54 & 13.88 \\
\hline Th & 2.13 & 5.30 & 3.66 & 3.70 & 2.71 & 4.98 & 2.65 & 4.58 & 3.44 & 2.93 \\
\hline U & ----- & ----- & 4.02 & 21.84 & 1.24 & $<0.01$ & 7.62 & $<0.01$ & 1.35 & $<0.01$ \\
\hline
\end{tabular}


APPENDIX B. INAA ANALYZES CONTINUED

\begin{tabular}{|c|c|c|c|c|c|c|c|c|c|c|}
\hline \multirow{3}{*}{$\begin{array}{l}\text { UNIT } \\
\text { Sample }\end{array}$} & \multicolumn{6}{|c|}{ OTHER DACITE INTRUSIONS } & \multicolumn{4}{|c|}{ UPPEER ELLENSBURG FORMATION } \\
\hline & \multicolumn{2}{|l|}{ PHA } & $\mathrm{HA}$ & \multicolumn{2}{|c|}{ PHA } & \multirow[b]{2}{*}{$8 e r r$} & \multicolumn{2}{|l|}{$\mathrm{CCH}$} & \multicolumn{2}{|l|}{$\mathrm{CCH}$} \\
\hline & 92242 & ferr & 93070 & gerr & 89157 & & 94001 & 8 error & 94021 & 8 error \\
\hline Naq & 3.41 & 0.20 & 2.84 & 0.21 & 0.78 & 0.34 & 2.39 & 0.25 & 1.41 & 0.37 \\
\hline $\mathrm{K} \frac{8}{8}$ & 1.74 & 22.30 & 1.83 & 25.79 & 0.77 & 15.33 & 1.51 & $<0.01$ & $-\cdots-$ & $\cdots-$ \\
\hline $\mathrm{Fe}^{8}$ & 3.04 & 0.78 & 2.25 & 0.88 & 4.97 & 0.82 & 2.94 & 0.96 & 4.45 & 0.78 \\
\hline Sc & 9.07 & 1.51 & 6.60 & 2.23 & 11.52 & 1.71 & 8.42 & 0.88 & 11.74 & 0.69 \\
\hline $\mathrm{Cr}$ & 19.42 & 7.08 & 13.44 & 8.19 & 10.53 & $<0.01$ & 17.82 & 24.64 & 28.68 & 13.59 \\
\hline Co & 9.84 & 2.47 & 7.49 & 2.01 & 6.31 & 5.06 & 26.32 & 1.63 & 25.04 & 1.68 \\
\hline $2 n$ & 57.79 & 30.19 & 42.44 & 32.59 & 126.36 & 30.88 & 63.95 & 33.26 & 67.44 & 36.72 \\
\hline $\mathrm{Ga}$ & 28.64 & 30.39 & 37.82 & 26.21 & 9.10 & 26.10 & $\cdots-$ & ----- & ---- & ----- \\
\hline A.s & 12.34 & $<0.01$ & 21.32 & $<0.01$ & 6.09 & 37.22 & ---- & $-\cdots-$ & 4.99 & 47.70 \\
\hline $\mathrm{Br}$ & 0.19 & $<0.01$ & 0.16 & $<0.01$ & 0.14 & $<0.01$ & ----- & $-\cdots-$ & ---- & $\cdots--$ \\
\hline $\mathrm{Rb}$ & 35.01 & 27.58 & 42.46 & 18.90 & 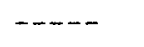 & ---- & 32.47 & 19.77 & 35.59 & $<0.01$ \\
\hline $\mathrm{Sr}$ & 509.96 & 10.61 & 582.83 & 8.53 & 338.19 & 36.69 & 842.70 & 8.77 & 633.49 & 32.92 \\
\hline $\mathrm{Zr}$ & 268.50 & $<0.01$ & 116.78 & 27.99 & 473.82 & 28.32 & $\ldots-$ & ----- & 373.80 & $<0.01$ \\
\hline $\mathrm{Sb}$ & ----- & ---- & 0.84 & 20.75 & ----- & ---- & 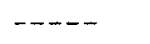 & ---- & ----- & ---- \\
\hline $\mathrm{Cs}$ & 1.35 & 22.55 & 1.03 & 17.53 & 3.00 & 21.55 & 2.05 & 11.88 & 2.76 & 10.77 \\
\hline $\mathrm{Ba}$ & 369.07 & $<0.01$ & 443.53 & 6.75 & 593.80 & 12.30 & 366.58 & $<0.01$ & 488.53 & 10.88 \\
\hline La & 15.39 & 3.40 & 18.09 & 2.38 & 11.46 & 3.77 & 15.85 & 4.96 & 16.22 & $<0.01$ \\
\hline $\mathrm{Ce}$ & 30.36 & 2.24 & 32.56 & 1.88 & 53.36 & 2.39 & 30.53 & 2.58 & 38.60 & 2.39 \\
\hline Nd & 14.93 & $<0.01$ & 16.22 & 45.77 & ---- & ----- & ----- & $\cdots$ & 48.33 & $<0.01$ \\
\hline Sm & 3.07 & 1.44 & 3.50 & 0.95 & 3.32 & 1.39 & 2.81 & 2.04 & 3.38 & 1.94 \\
\hline Eu & 1.04 & 2.86 & 0.97 & 2.62 & 1.94 & 3.12 & 1.08 & 9.56 & 1.10 & 3.69 \\
\hline $\mathrm{Tb}$ & 0.32 & $<0.01$ & 0.38 & 8.73 & 1.10 & 7.06 & ----- & ---- & 0.78 & 13.79 \\
\hline $\mathrm{Yb}$ & 0.90 & 17.45 & 1.07 & 16.03 & 4.22 & 9.11 & 1.49 & 22.89 & 1.80 & 14.56 \\
\hline Lu & 0.13 & 13.89 & 0.16 & 13.01 & 0.58 & 13.90 & 0.14 & 16.42 & 0.23 & 11.73 \\
\hline $\mathrm{Hf}$ & 3.32 & 4.45 & 3.98 & 3.27 & 6.97 & 3.67 & 3.48 & 4.70 & 4.00 & 7.48 \\
\hline $\mathrm{Ta}$ & 0.81 & 15.12 & 0.65 & 16.12 & 1.24 & 21.30 & 0.55 & 11.12 & 0.62 & 17.89 \\
\hline Th & 1.79 & 5.08 & 3.45 & 2.79 & 6.05 & 3.73 & 2.65 & 5.54 & 3.04 & 4.65 \\
\hline U & 8.44 & $<0.01$ & 1.96 & 15.07 & 10.70 & $<0.01$ & 4.94 & 44.75 & ---- & ----- \\
\hline
\end{tabular}


APPENDIX B. INAA ANALYZES CONTINUED

\begin{tabular}{|c|c|c|c|c|c|c|c|c|c|c|}
\hline$\overline{\mathrm{UNIT}}$ & & & & $\overline{\overline{U P I}}$ & R ELLENSB & RG FORMATI & & & & \\
\hline Sample & $\mathrm{CCH}$ & & $\mathrm{CCH}$ & & $\mathrm{CCH}$ & & $\mathrm{CCH}$ & & $\mathrm{CCH}$ & \\
\hline & 94023 & \& error & 94024 & 8 error & 94025 & 8 error & 94026 & 8 error & 94027 & 8 error \\
\hline$\overline{\mathrm{Na}}$ & 1.75 & 0.29 & 1.45 & 0.32 & 2.17 & 0.27 & 2.48 & 0.28 & 2.31 & 0.27 \\
\hline$K^{8}$ & 1.61 & 14.53 & 1.32 & 22.14 & 1.48 & 18.88 & 1.80 & 18.24 & 1.69 & 20.41 \\
\hline $\mathrm{Fe}_{8}^{8}$ & 2.72 & 1.22 & 3.74 & 0.84 & 3.07 & 0.92 & 3.36 & 1.06 & 3.54 & 0.92 \\
\hline $\mathrm{Sc}$ & 7.26 & 0.54 & 10.56 & 0.66 & 11.98 & 0.59 & 9.79 & 0.86 & 11.30 & 0.69 \\
\hline $\mathrm{Cr}$ & 18.50 & 22.59 & 27.84 & 7.75 & 15.48 & 12.64 & 17.16 & 12.68 & 16.95 & 15.59 \\
\hline Co & 39.25 & 0.95 & 34.65 & 1.33 & 29.24 & 1.54 & 28.29 & 1.80 & 20.27 & 1.82 \\
\hline $\mathrm{Zn}$ & 58.46 & 32.75 & 79.61 & 26.66 & 88.11 & 26.20 & 58.01 & 40.32 & 84.34 & 26.94 \\
\hline Ga & ---- & ---- & $\ldots$ & ---- & ---- & ---- & ---- & ----- & $\ldots-$. & $-\ldots-$ \\
\hline As & 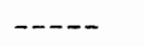 & $\ldots$ & --- & -..- & 2.55 & 43.38 & 286.31 & $<0.01$ & 2.33 & 45.20 \\
\hline $\mathrm{Br}$ & ---- & ---- & ---- & $-\infty-$ & ---- & $\ldots--$ & ---- & $\ldots-$ & ---- & ----- \\
\hline $\mathrm{Rb}$ & 7.26 & 28.04 & 31.29 & 38.88 & 4.02 & 18.18 & 45.87 & 32.35 & 51.83 & 14.09 \\
\hline $\mathrm{Sr}$ & 581.50 & 11.69 & 587.10 & 12.52 & 571.07 & 16.03 & 862.60 & 13.94 & 529.44 & 16.51 \\
\hline $\mathrm{Zr}$ & ----- & ----- & 313.95 & $<0.01$ & 189.14 & 41.95 & 396.42 & 38.68 & 183.71 & 49.84 \\
\hline $\mathrm{Sb}$ & ----- & ----- & -... & ----- & 1.68 & $<0.01$ & $-\cdots$ & ---- & 0.85 & $<0.01$ \\
\hline Cs & 1.76 & 20.75 & 1.26 & 35.68 & 2.57 & 8.42 & 1.36 & $<0.01$ & 3.75 & 6.83 \\
\hline $\mathrm{Ba}$ & 494.85 & 8.31 & 39.60 & $<0.01$ & 387.45 & $<0.01$ & 399.26 & 9.55 & 443.63 & 14.15 \\
\hline La & 15.72 & 5.92 & 17.16 & 3.40 & 19.54 & 4.97 & 17.74 & 5.22 & 16.36 & 5.72 \\
\hline $\mathrm{Ce}$ & 30.97 & 2.73 & 36.65 & 2.31 & 31.40 & 2.94 & 46.12 & 2.15 & 32.33 & 2.59 \\
\hline Nd & ---- & ----- & 21.75 & 22.99 & 20.50 & $<0.01$ & 19.95 & 19.29 & 59.12 & $<0.01$ \\
\hline $\mathrm{Sm}$ & 2.90 & 2.45 & 3.36 & 1.87 & 4.08 & 1.87 & 3.08 & 2.92 & 3.42 & 2.57 \\
\hline $\mathrm{Eu}$ & 0.90 & 3.84 & 1.12 & 3.12 & 1.27 & 2.83 & 1.09 & 9.43 & 1.11 & 10.22 \\
\hline $\mathrm{Tb}$ & 1.18 & $<0.01$ & 1.12 & $<0.01$ & ----- & $\cdots+$ & 1.70 & $<0.01$ & 1.68 & $<0.01$ \\
\hline $\mathrm{Yb}$ & $\ldots-$ & $\ldots-$ & 1.08 & 20.80 & 2.19 & 12.98 & 1.16 & 16.87 & 2.06 & 11.88 \\
\hline $\mathrm{Lu}$ & 0.23 & 29.94 & 0.20 & 13.35 & 0.28 & 10.54 & 0.16 & 15.97 & 0.24 & 10.95 \\
\hline $\mathrm{Hf}$ & 3.55 & 3.95 & 3.32 & 4.41 & 3.91 & 4.20 & 4.05 & 4.88 & 3.83 & 3.90 \\
\hline $\mathrm{Ta}$ & 0.71 & 9.21 & 0.66 & 25.39 & 0.58 & $<0.01$ & 0.63 & $<0.01$ & 0.83 & 15.61 \\
\hline Th & 3.11 & 7.25 & 3.12 & 5.19 & 3.62 & 4.27 & 4.04 & 3.90 & 3.52 & 4.40 \\
\hline$\underline{\mathrm{u}}$ & ----- & ----- & 15.84 & $<0.01$ & 10.54 & $<0.01$ & ----- & ---- & 16.05 & $<0.01$ \\
\hline
\end{tabular}

All analyzes are in ppm unless otherwise specified 
APPENDIX B. INAA ANALYZES CONTINUED

\begin{tabular}{|c|c|c|c|c|c|c|c|c|c|c|}
\hline \multirow{3}{*}{$\begin{array}{l}\text { UNIT } \\
\text { Sample }\end{array}$} & \multicolumn{10}{|c|}{ UPPER ELLENSBURG FORMAT ION } \\
\hline & \multicolumn{2}{|l|}{$\mathrm{CCH}$} & \multicolumn{2}{|l|}{$\mathrm{CCH}$} & \multicolumn{2}{|l|}{$\mathrm{CCH}$} & \multirow{2}{*}{$\begin{array}{c}\mathrm{CCH} \\
94032\end{array}$} & \multicolumn{3}{|c|}{$\mathrm{CCH}$} \\
\hline & 94028 & $\&$ error & 94029 & f error & 94031 & 8 error & & f error & 94033 & \& error \\
\hline$\overline{\mathrm{Na}}$ & 1.82 & 0.30 & 2.48 & 0.26 & 2.80 & 0.26 & 2.80 & 0.26 & 1.48 & 0.39 \\
\hline $\mathrm{K} 8$ & 1.13 & 25.21 & 1.38 & 18.09 & 1.57 & 31.75 & 1.80 & 29.73 & 1.65 & 20.34 \\
\hline $\mathrm{Fe} z$ & 2.58 & 1.02 & 3.12 & 1.12 & 2.76 & 0.91 & 3.12 & 1.01 & 3.43 & 0.93 \\
\hline $\mathrm{Sc}$ & 11.29 & 0.65 & 8.81 & 0.90 & 7.80 & 0.86 & 7.65 & 0.89 & 9.38 & 0.94 \\
\hline $\mathrm{Cr}$ & 25.22 & 8.00 & 23.64 & 16.40 & 34.64 & 10.01 & 17.34 & 12.02 & 29.30 & 13.44 \\
\hline Co & 30.13 & 1.47 & 25.64 & 1.71 & 18.65 & 1.52 & 16.85 & 1.60 & 21.38 & 2.13 \\
\hline $2 n$ & 70.30 & 33.70 & 62.51 & 35.05 & 56.42 & 35.06 & 61.20 & 33.70 & 51.95 & 47.63 \\
\hline $\mathrm{Ga}$ & ---- & $\ldots .$. & ---- & $-\ldots$ & ---- & $\ldots$. & $-\ldots-$ & ---- & ---- & $\ldots \ldots$ \\
\hline As & 3.89 & 42.37 & 10.58 & 46.31 & 40.14 & $<0.01$ & ..... &.--- & ---- & $\ldots-$ \\
\hline $\mathrm{Br}$ & ---- & ---- & ---- & $\ldots--$ & $\ldots$ & ---- & --- & $\ldots-$ & ----- & ---- \\
\hline $\mathrm{Rb}$ & 31.13 & 29.94 & $\ldots . .-$ & $<0.01$ & 30.26 & 32.82 & $\ldots-\ldots$ & ---- & 28.54 & 24.75 \\
\hline $\mathrm{sr}$ & 859.45 & 19.56 & 735.04 & 11.43 & 612.51 & 12.00 & 666.64 & 10.80 & 563.30 & 16.27 \\
\hline $2 r$ & 263.43 & $<0.01$ & 306.20 & 37.01 & 265.99 & 35.13 & 262.25 & 33.43 & $\ldots$ & ---- \\
\hline $\mathrm{Sb}$ & ----- & ---- & ---- &.--- & ----- & ---- & --- & ---- & ----- & -..- \\
\hline Cs & 1.88 & 28.57 & 1.80 & 19.44 & 0.89 & 24.11 & 2.18 & 23.86 & 1.57 & 30.75 \\
\hline $\mathrm{Ba}$ & 407.00 & 11.08 & 425.31 & 9.47 & 376.36 & 9.56 & 413.42 & 9.32 & 403.74 & 10.29 \\
\hline La & 19.32 & 3.63 & 19.07 & 4.24 & 16.50 & 6.12 & 13.65 & 9.15 & 17.02 & 3.67 \\
\hline $\mathrm{Ce}$ & 42.98 & 2.15 & 36.64 & 2.28 & 32.34 & 2.31 & 28.41 & 3.05 & 25.54 & 3.44 \\
\hline $\mathrm{Nd}$ & 21.53 & 18.06 & $\ldots$ & $-\ldots-$ & ---- & ----- & 17.14 & $<0.01$ & ----- & $\cdots \cdots$ \\
\hline Sm & 3.74 & 2.32 & 3.12 & 2.63 & 2.98 & 4.57 & 2.84 & 3.91 & 4.16 & 2.08 \\
\hline $\mathrm{Eu}$ & 1.18 & 9.74 & 1.05 & 8.79 & 0.99 & 3.26 & 1.09 & 3.45 & 1.14 & 3.39 \\
\hline $\mathrm{Tb}$ & 0.52 & $<0.01$ & 0.64 & 16.11 & 0.65 & 15.24 & 1.49 & $<0.01$ & 0.49 & $<0.01$ \\
\hline $\mathrm{Yb}$ & 1.64 & 13.85 & 1.70 & 14.04 & 1.41 & 17.55 & 1.22 & $<0.01$ & 1.78 & 16.98 \\
\hline Lu & 0.26 & 10.88 & 0.18 & 14.75 & 0.18 & $<0.01$ & 0.23 & $<0.01$ & 0.29 & 11.92 \\
\hline $\mathrm{Hf}$ & 3.99 & 3.85 & 3.60 & 4.00 & 3.59 & 5.08 & 3.59 & 3.58 & 2.95 & 7.14 \\
\hline $\mathrm{Ta}$ & 0.67 & $<0.01$ & 1.21 & 8.17 & 1.18 & 5.48 & 0.70 & $<0.01$ & 0.74 & $<0.01$ \\
\hline Th & 3.91 & 3.45 & 3.93 & 3.64 & 2.76 & 4.56 & 2.67 & 5.37 & 2.53 & 5.34 \\
\hline $\mathrm{U}$ & 15.39 & $<0.01$ & ----- & ----- & $---\cdots$ & ----- & 5.57 & $<0.01$ & 22.93 & $<0.01$ \\
\hline
\end{tabular}

All analyzes are in ppm unless otherwise specified 
APPENDIX B. INAA ANALYZES CONT INUED

\begin{tabular}{|c|c|c|c|c|c|c|c|c|c|c|c|}
\hline \multirow{3}{*}{$\begin{array}{l}\text { UNIT } \\
\text { Sample }\end{array}$} & & \multicolumn{10}{|c|}{ UPPER ELLENSBURG FORMAT ION } \\
\hline & & \multicolumn{2}{|l|}{$\mathrm{CCH}$} & \multicolumn{2}{|l|}{$\mathrm{CCH}$} & \multicolumn{2}{|l|}{$\mathrm{CCH}$} & \multicolumn{2}{|l|}{$\mathrm{CCH}$} & \multicolumn{2}{|l|}{$\mathrm{CCH}$} \\
\hline & & 94035 & 8 error & 94039 & 8 error & 94040 & \& error & 94041 & $\&$ error & 94060 & \& error \\
\hline $\mathrm{Na} 8$ & & 2.56 & 0.26 & 2.78 & 0.29 & 2.44 & 0.28 & 2.64 & 0.26 & 2.53 & 0.28 \\
\hline $\mathrm{Kg}$ & & 1.26 & $<0.01$ & 1.96 & 24.88 & 1.74 & 19.47 & 1.91 & 26.67 & 1.63 & 23.81 \\
\hline $\mathrm{Fe} z$ & & 3.59 & 0.91 & 2.92 & 0.91 & 2.94 & 0.96 & 3.51 & 0.81 & 3.06 & 0.92 \\
\hline Sc & & 10.93 & 0.72 & 8.01 & 0.89 & 7.96 & 0.76 & 9.24 & 0.74 & 9.89 & 0.86 \\
\hline $\mathrm{Cr}$ & & 22.98 & 8.79 & 15.28 & 12.76 & 15.33 & 12.54 & 34.57 & $<0.01$ & 20.27 & 32.88 \\
\hline Co & & 19.24 & 1.96 & 23.38 & 1.25 & 26.59 & 1.66 & 24.63 & 1.23 & 18.19 & 1.56 \\
\hline $2 n$ & & 65.08 & 35.81 & 60.57 & 32.82 & 58.92 & 35.15 & 65.50 & 33.00 & 54.64 & 41.57 \\
\hline $\mathrm{Ga}$ & & ---- & $\cdots$ & ---- & ---- & ---- & ---- & $-\cdots$ & ---- & ---- & $-\cdots$ \\
\hline As & & ---- & ---- & 225.48 & $<0.01$ & 2.04 & 49.65 & 29.20 & $<0.01$ & 2.58 & 46.90 \\
\hline $\mathrm{Br}$ & & ----- & ----- & $-\cdots$ & ---- & ---- & $\cdots-$ & ---- & ---- & $-\cdots$ & ---- \\
\hline $\mathrm{Rb}$ & & ----- & ----- & 37.65 & $<0.01$ & 44.15 & 28.41 & 47.91 & 24.00 & 33.91 & 25.85 \\
\hline $\mathrm{Sr}$ & & 785.92 & 16.48 & 847.80 & 9.09 & 846.98 & 10.08 & 590.17 & 15.07 & 727.43 & $-\cdots$ \\
\hline $\mathrm{Zr}$ & & ----- & ---- & 244.68 & $<0.01$ & 151.38 & $<0.01$ & ---- & $\ldots-$ & 362.31 & 33.70 \\
\hline $\mathrm{Sb}$ & & -.-- & ---- & 0.54 & $<0.01$ & $\cdots$ & ---- & ----- & $\ldots-$ & ----- & ---- \\
\hline Cs & . & 0.76 & 46.54 & 1.57 & 21.66 & 1.69 & 19.42 & 1.66 & 14.10 & 1.70 & 26.00 \\
\hline $\mathrm{Ba}$ & & 388.19 & 12.14 & 398.70 & $<0.01$ & 396.56 & 10.92 & 397.45 & 11.24 & 373.68 & 11.49 \\
\hline La & & 14.40 & 7.39 & 16.62 & 6.26 & 14.58 & 8.45 & 14.01 & 4.87 & 16.64 & 4.23 \\
\hline $\mathrm{Ce}$ & & 27.02 & 3.26 & 32.08 & 2.69 & 30.12 & 2.92 & 28.07 & 3.16 & 31.87 & 2.69 \\
\hline $\mathrm{Nd}$ & & 18.47 & 38.45 & 16.67 & $<0.01$ & 18.64 & 30.23 & $-\cdots$ & $\ldots$ & ----- & ----- \\
\hline $\mathrm{Sm}$ & & 2.85 & 3.22 & 2.56 & 4.46 & 2.74 & 1.99 & 2.93 & 3.11 & 2.77 & 2.94 \\
\hline $\mathrm{Eu}$ & & 1.00 & 3.73 & 1.18 & $<0.01$ & 1.02 & 8.81 & 1.10 & 8.39 & 0.98 & 3.89 \\
\hline $\mathrm{Tb}$ & & 0.64 & 15.00 & 1.06 & $<0.01$ & 1.77 & $<0.01$ & 0.58 & $<0.01$ & 0.86 & $<0.01$ \\
\hline $\mathrm{Yb}$ & & 1.32 & 17.58 & 1.22 & 17.92 & 1.50 & 23.37 & 1.18 & 12.93 & 1.31 & 15.19 \\
\hline $\mathrm{Lu}$ & & 0.16 & 17.32 & 0.15 & 27.45 & 0.27 & $<0.01$ & 0.20 & 16.83 & 0.17 & $<0.01$ \\
\hline $\mathrm{Hf}$ & & 3.16 & 5.60 & 3.52 & 4.83 & 3.53 & 4.05 & 3.33 & 4.61 & 3.37 & 4.48 \\
\hline $\mathrm{Ta}$ & & 0.56 & $<0.01$ & 1.21 & 11.07 & 1.13 & 5.79 & 0.69 & 8.83 & 0.95 & 16.43 \\
\hline $\mathrm{Th}$ & & 2.63 & 4.93 & 2.36 & 5.23 & 2.59 & 6.08 & 2.43 & 5.98 & 3.79 & 3.83 \\
\hline U & & ----- & ----- & 5.43 & $<0.01$ & 8.86 & 37.91 & 18.53 & $<0.01$ & ----- & ----- \\
\hline
\end{tabular}


APPENDIX B. INAA ANALYZES CONTINUED

\begin{tabular}{|c|c|c|c|c|c|c|c|c|c|c|}
\hline \multirow{3}{*}{$\begin{array}{l}\text { UNIT } \\
\text { Sample }\end{array}$} & \multicolumn{10}{|c|}{ UPPER ELLENSBURG EORMATION } \\
\hline & \multicolumn{2}{|l|}{$\mathrm{CCH}$} & \multicolumn{2}{|l|}{$\mathrm{CCH}$} & \multicolumn{2}{|l|}{$\mathrm{CCH}$} & \multicolumn{2}{|l|}{$\mathrm{CCH}$} & \multicolumn{2}{|l|}{$\mathrm{CCH}$} \\
\hline & 94096 & \& error & 94097 & \& error & 94105 & error & 94111 & error & 94113 & \& error \\
\hline$\overline{\mathrm{Na}}$ & 2.51 & 0.33 & 2.44 & 0.31 & 2.37 & 0.40 & 2.77 & 0.31 & 2.61 & 0.31 \\
\hline $\mathrm{K} 8$ & 1.24 & 25.28 & 1.42 & 29.54 & 2.54 & 19.74 & 2.04 & $<0.01$ & 1.90 & 21.46 \\
\hline Fe & 4.13 & 0.80 & 3.50 & 0.90 & 3.23 & 0.99 & 2.96 & 0.90 & 2.68 & 1.07 \\
\hline Sc & 13.66 & 0.67 & 9.88 & 0.69 & 9.03 & 0.89 & 8.02 & 0.73 & 7.13 & 0.92 \\
\hline $\mathrm{Cr}$ & 36.82 & 6.62 & 20.34 & 9.45 & 41.64 & 6.07 & 21.19 & 15.78 & 27.39 & 11.99 \\
\hline Co & 21.32 & 2.00 & 22.39 & 1.73 & 21.81 & 1.98 & 21.30 & 1.33 & 21.38 & 1.75 \\
\hline$Z_{n}$ & 88.21 & 24.69 & 70.16 & 30.71 & 61.29 & 38.33 & 58.76 & 34.44 & 61.69 & 27.19 \\
\hline $\mathrm{Ga}$ & $-\ldots--$ & $\ldots-\ldots$ & $\ldots \ldots$ & ---- & ---- & $-\ldots-$ & ---- & ---- & $\ldots--$ & $-\cdots-$ \\
\hline As & 26.48 & $<0.01$ & 5.60 & 47.03 & 35.95 & $<0.01$ & 27.76 & $<0.01$ & 213.25 & $<0.01$ \\
\hline $\mathrm{Br}$ & ---- & ---- & ---- & --- & -.... & $\ldots-$ & $\ldots-$ & $-\cdots-$ & ---- & $--\ldots$ \\
\hline $\mathrm{Rb}$ & 34.85 & $<0.01$ & 15.36 & 37.30 & 34.20 & 34.24 & 36.96 & 30.88 & 26.08 & 37.19 \\
\hline $\mathrm{Sr}$ & 712.05 & 12.62 & 612.70 & 13.43 & 736.73 & 20.00 & 499.60 & 14.20 & 612.83 & 11.14 \\
\hline $\mathrm{Zr}$ & $-\ldots$ & ---- & 199.87 & $<0.01$ & 357.57 & 32.41 & ---- & ---- & 309.73 & $<0.01$ \\
\hline $\mathrm{Sb}$ & $\ldots . .$. & $\ldots$ & 4.11 & $<0.01$ & $\ldots-$ & $\ldots-$ & $-\ldots$ & $\ldots-$ & $\ldots-$ & ---- \\
\hline $\mathrm{Cs}$ & $-\cdots-$ & $-\cdots-$ & 0.53 & 3.88 & 2.38 & 17.50 & 1.50 & $<0.01$ & 2.25 & 19.90 \\
\hline $\mathrm{Ba}$ & 503.33 & 9.72 & 417.18 & 9.78 & 488.04 & 10.02 & 441.14 & 9.95 & 429.69 & 9.09 \\
\hline $\mathrm{La}$ & 18.21 & 4.05 & 13.81 & 5.83 & 19.84 & 6.09 & 15.33 & 5.16 & 16.46 & 5.19 \\
\hline $\mathrm{Ce}$ & 40.75 & 2.57 & 26.61 & 3.04 & 40.09 & 2.60 & 29.77 & 2.79 & 30.13 & 2.61 \\
\hline Nd & 24.53 & 28.71 & 13.42 & $<0.01$ & 22.23 & 29.36 & $-\ldots$ & $\ldots . .-$ & $\ldots-$ & $-\cdots-$ \\
\hline Sm & 3.52 & 2.11 & 2.38 & 2.92 & 3.65 & 2.79 & 2.97 & 2.30 & 2.97 & 3.05 \\
\hline Eu & 1.25 & 8.18 & 0.92 & 8.81 & 1.20 & 8.22 & 0.98 & 3.56 & 0.95 & 3.71 \\
\hline $\mathrm{Tb}$ & 1.91 & $<0.01$ & 0.64 & 35.90 & 0.52 & 15.03 & 0.48 & 14.42 & 0.63 & 31.05 \\
\hline $\mathrm{Yb}$ & 1.75 & $<0.01$ & 0.98 & 31.35 & 1.18 & 20.17 & 1.01 & 18.09 & 1.29 & 18.28 \\
\hline Lu & 0.20 & $<0.01$ & 0.28 & $<0.01$ & 0.20 & 18.59 & 0.17 & 14.73 & 0.16 & 19.29 \\
\hline Hf & 4.09 & 4.76 & 3.27 & 5.45 & 3.54 & 4.60 & 3.41 & 5.14 & 3.64 & 3.79 \\
\hline $\mathrm{Ta}$ & 0.73 & $<0.01$ & 0.75 & 8.42 & 0.72 & 22.64 & 0.47 & 24.89 & 1.19 & 10.60 \\
\hline Th & 3.84 & 6.48 & 3.33 & 4.12 & 3.27 & 4.31 & 2.94 & 4.73 & 2.68 & 4.80 \\
\hline $\mathrm{U}$ & --- & ---- & $-\ldots-$ & ----- & 3.22 & $<0.01$ & $---\ldots$ & $-\ldots-$ & $\ldots . .-$ & ---- \\
\hline
\end{tabular}

All analyzes are in ppm unless otherwise specified 
APPENDIX B. INAA ANALYZES CONTINUED

\begin{tabular}{|c|c|c|c|c|c|c|c|c|c|c|}
\hline \multirow{3}{*}{$\begin{array}{l}\text { UNIT } \\
\text { Sample }\end{array}$} & \multicolumn{10}{|c|}{ UPPER ELLENSBURG FORMATION } \\
\hline & \multicolumn{2}{|l|}{$\mathrm{CCH}$} & \multicolumn{2}{|l|}{$\mathrm{CCH}$} & \multicolumn{2}{|l|}{$\mathrm{CCH}$} & \multicolumn{2}{|l|}{$\mathrm{CCH}$} & \multicolumn{2}{|l|}{$\mathrm{CCH}$} \\
\hline & 94114 & 8 error & 94115 & 8 error & 94124 & 8 error & 94127 & 8 error & 94128 & 8 error \\
\hline $\mathrm{Na}{ }^{8}$ & 2.86 & 0.31 & 2.85 & 0.34 & 2.91 & 0.33 & 2.42 & 0.36 & 0.66 & 0.73 \\
\hline$K 8$ & 2.83 & $<0.01$ & 1.92 & 26.33 & 2.79 & 26.29 & 1.52 & 30.61 & $--\cdots$ & ---- \\
\hline $\mathrm{Fe}^{\circ}$ & 2.59 & 0.98 & 3.14 & 0.86 & 3.13 & 0.94 & 3.46 & 0.88 & 3.90 & 0.93 \\
\hline Sc & 6.28 & 0.74 & 8.66 & 0.73 & 8.56 & 0.84 & 10.80 & 0.73 & 14.05 & 0.45 \\
\hline $\mathrm{Cr}$ & 13.05 & 15.97 & 21.10 & 13.66 & 15.25 & 11.39 & 22.59 & 8.92 & 56.30 & 11.06 \\
\hline Co & 12.57 & 1.97 & 23.83 & 1.39 & 13.75 & 2.55 & 24.63 & 1.27 & 21.59 & 2.04 \\
\hline $2 n$ & 50.93 & 27.88 & 54.53 & 30.40 & 62.36 & 34.30 & 92.41 & 22.96 & 75.39 & 38.48 \\
\hline $\mathrm{Ga}$ & ---- & ---- & ---- & $-\cdots$ & ---- & $-\infty-\infty$ & $-\cdots$ & ---- & ---- & $-\cdots--$ \\
\hline As & 226.97 & $<0.01$ & 314.13 & $<0.01$ & 264.30 & $<0.01$ & 242.22 & $<0.01$ & 2.61 & 34.94 \\
\hline$B r$ & ---- & ---- & $\ldots$ & ---- & $-\cdots$ & ----- & $-\cdots$ & $\cdots--$ & $-\cdots$ & --- \\
\hline $\mathrm{Rb}$ & 44.33 & 42.38 & 38.47 & $<0.01$ & --- & ---- & 39.79 & 21.49 & -..-- & ---- \\
\hline $\mathrm{Sr}$ & 598.12 & 10.70 & 1112.40 & 6.73 & 684.55 & 11.78 & 777.54 & 11.56 & 525.38 & 31.66 \\
\hline $\mathrm{zr}_{\mathrm{r}}$ & 196.18 & 30.90 & 185.67 & 28.83 & 182.85 & 36.39 & 208.69 & $<0.01$ & 339.77 & $<0.01$ \\
\hline $\mathrm{Sb}$ & 2.69 & $<0.01$ & ---- & ---- & 0.55 & $<0.01$ & 0.65 & $<0.01$ & --- & ---- \\
\hline Cs & 0.58 & 23.03 & 0.46 & 34.92 & 1.24 & 17.89 & 1.50 & 14.79 & 2.51 & 30.48 \\
\hline $\mathrm{Ba}$ & 600.67 & 18.77 & 537.16 & 16.90 & 472.79 & 8.82 & 437.30 & 11.57 & 679.39 & 7.93 \\
\hline $\mathrm{La}$ & 16.23 & 6.92 & 25.07 & 4.65 & 22.37 & 3.57 & 18.74 & 4.11 & 21.75 & 2.41 \\
\hline $\mathrm{Ce}$ & 38.33 & 2.14 & 54.79 & 1.85 & 31.51 & 2.76 & 38.72 & 2.26 & 10.11 & 2.85 \\
\hline $\mathrm{Nd}$ & 23.25 & $<0.01$ & ---- & $-\cdots$ & 27.03 & 15.08 & 22.58 & $<0.01$ & ----- & $\cdots-$ \\
\hline Sm & 3.01 & 2.52 & 4.02 & 2.29 & 3.97 & 1.45 & 3.37 & 2.08 & 4.39 & 1.50 \\
\hline Eu & 1.00 & 7.36 & 1.28 & 6.83 & 1.30 & 7.82 & 1.13 & 3.30 & 1.31 & 9.16 \\
\hline $\mathrm{Tb}$ & 1.74 & $<0.01$ & 0.64 & $<0.01$ & 0.45 & $<0.01$ & 0.59 & $<0.01$ & 1.03 & 30.04 \\
\hline $\mathrm{Yb}$ & 1.35 & 21.30 & 1.44 & 14.26 & 1.04 & 16.95 & 2.19 & 19.65 & 2.08 & 13.93 \\
\hline Lu & ---- & $-\cdots$ & 0.66 & $<0.01$ & 0.17 & $<0.01$ & 0.21 & $<0.01$ & 0.32 & 11.75 \\
\hline Hf & 3.98 & 3.83 & 4.18 & 4.10 & 3.71 & 5.04 & 4.09 & 4.52 & 4.46 & 5.45 \\
\hline $\mathrm{Ta}$ & 0.74 & 13.15 & 1.20 & 12.38 & 0.54 & 20.54 & 0.70 & $<0.01$ & 0.75 & 20.22 \\
\hline Th & 3.13 & 5.70 & 4.60 & 3.45 & 2.74 & 4.46 & 3.48 & 4.18 & 4.13 & 4.14 \\
\hline$U$ & 21.64 & $<0.01$ & 3.09 & $<0.01$ & 2.42 & $<0.01$ & $\ldots-$ & $---\cdots$ & 6.29 & $<0.01$ \\
\hline
\end{tabular}

All analyzes are in ppm unless otherwise specified 
APPENDIX B. INAA ANALYZES CONTINUED

\begin{tabular}{|c|c|c|c|c|c|c|c|c|c|c|}
\hline \multirow{3}{*}{$\begin{array}{l}\text { UNIT } \\
\text { Sample }\end{array}$} & \multicolumn{2}{|c|}{ UPPER ELL. FORM. } & \multicolumn{8}{|c|}{ LOWER ELLENSBURG FORMAT ION } \\
\hline & $\mathrm{CCH}$ & & \multicolumn{2}{|l|}{$\mathrm{CCH}$} & \multicolumn{2}{|l|}{$\mathrm{CCH}$} & \multicolumn{2}{|l|}{$\mathrm{CCH}$} & \multicolumn{2}{|l|}{$\mathrm{CCH}$} \\
\hline & 94130 & 8 error & 94061 & 8 error & 94062 & 8 error & 94063 & 8 error & 94086 & 8 error \\
\hline $\mathrm{Na}$ & 2.38 & 0.34 & 2.05 & 0.31 & 1.98 & 0.30 & 1.80 & 0.32 & 1.48 & 0.43 \\
\hline$K \frac{8}{8}$ & 1.87 & 29.20 & 0.79 & 22.66 & 1.85 & 15.72 & 1.85 & 17.09 & 2.99 & 19.57 \\
\hline $\mathrm{Fe}$ 용 & 3.24 & 0.84 & 2.42 & 1.21 & 2.72 & 1.10 & 2.82 & 0.98 & 2.85 & 1.07 \\
\hline Sc & 9.15 & 0.94 & 18.62 & 0.55 & 14.52 & 0.54 & 18.75 & 0.44 & 10.09 & 0.80 \\
\hline $\mathrm{Cr}$ & 21.32 & 22.59 & 5.54 & 41.85 & 9.02 & 39.28 & 18.69 & 22.66 & 8.01 & 25.26 \\
\hline Co & 19.48 & 1.76 & 33.79 & 1.44 & 13.38 & 2.47 & 23.72 & 1.66 & 16.82 & 2.26 \\
\hline Zn & 72.85 & 24.81 & 74.96 & 39.37 & 64.70 & 40.05 & 83.17 & 34.54 & 66.30 & 34.10 \\
\hline $\mathrm{Ga}$ & ----- & ---- & ----- & --- & $-\cdots-$ & $\cdots-$ & ---- & ---- & $\cdots-$ & ---- \\
\hline As & ---- & ----- & 174.47 & $<0.01$ & 5.79 & 38.67 & 4.79 & 44.05 & 13.62 & 16.69 \\
\hline $\mathrm{Br}$ & $-\cdots$ & ---- & $\cdots$ & ---- & ----- & ---- & ---- & $-\cdots$ & ---- & ----- \\
\hline $\mathrm{Rb}$ & 33.25 & 29.57 & 45.04 & 21.87 & 69.68 & 11.00 & 49.78 & 18.96 & 103.42 & 8.33 \\
\hline Sr & 682.45 & 11.24 & 564.44 & 27.21 & 342.15 & $<0.01$ & 406.40 & 21.70 & 174.16 & 43.01 \\
\hline $\mathrm{Zr}$ & 539.83 & 31.88 & 310.99 & $<0.01$ & 238.17 & 40.50 & ----- & ---- & 221.39 & 25.30 \\
\hline $\mathrm{Sb}$ & ----- & $\cdots-\cdots$ & ---- & ----- & $\cdots$ & --- & ----- & ---- & 1.33 & 19.17 \\
\hline Cs & 2.19 & 15.34 & 3.02 & 9.00 & 3.83 & 10.45 & 3.25 & 14.67 & 4.92 & 4.99 \\
\hline $\mathrm{Ba}$ & 376.59 & 9.17 & 648.67 & $<0.01$ & 600.67 & 7.90 & 591.62 & $<0.01$ & 754.67 & 6.18 \\
\hline La & 16.32 & 5.03 & 33.05 & 2.10 & 19.78 & 3.66 & 14.35 & 3.61 & 29.76 & 2.67 \\
\hline $\mathrm{Ce}$ & 29.28 & 2.61 & 71.00 & 1.54 & 35.97 & 2.71 & 26.84 & 3.35 & 58.63 & 1.79 \\
\hline $\mathrm{Nd}$ & ---- & $\cdots-$ & 39.21 & $<0.01$ & $\cdots$ & --- & ---- & ---- & 29.83 & 16.52 \\
\hline $\mathrm{Sm}$ & 3.04 & 1.63 & 8.16 & 1.14 & 3.74 & 2.13 & 2.64 & 2.62 & 6.08 & 0.93 \\
\hline Eu & 1.02 & 3.23 & 2.00 & 6.33 & 1.31 & 8.08 & 1.06 & 9.27 & 1.16 & 3.60 \\
\hline $\mathrm{Tb}$ & 1.37 & $<0.01$ & 1.34 & 6.39 & 0.93 & 13.11 & 0.72 & 14.53 & 1.01 & 7.47 \\
\hline $\mathrm{Yb}$ & 1.49 & 16.41 & 3.85 & 10.59 & 2.96 & 9.56 & 1.93 & 11.97 & 3.71 & 9.33 \\
\hline Lu & 0.18 & 12.38 & 0.50 & 17.64 & 0.46 & 9.66 & 0.32 & 10.18 & 0.60 & 8.71 \\
\hline $\mathrm{Hf}$ & 3.55 & 4.92 & 4.51 & 4.18 & 4.07 & 4.73 & 4.03 & 4.85 & 5.58 & 2.78 \\
\hline $\mathrm{Ta}$ & 0.80 & 16.38 & 0.66 & 13.36 & 0.79 & 17.33 & 0.69 & 16.89 & 0.63 & $<0.01$ \\
\hline Th & 3.06 & 4.50 & 9.87 & 1.98 & 9.84 & 1.84 & 9.43 & 1.87 & 12.26 & 1.49 \\
\hline$\underline{U}$ & 2.78 & $<0.01$ & 18.55 & $<0.01$ & 8.29 & $<0.01$ & 3.57 & $<0.01$ & 4.72 & 9.56 \\
\hline
\end{tabular}


APPENDIX B. INAA ANALYZES CONT INUED

\begin{tabular}{|c|c|c|c|c|c|c|c|c|c|c|}
\hline \multirow{3}{*}{$\begin{array}{l}\overline{\text { UNIT }} \\
\text { Sample }\end{array}$} & \multicolumn{10}{|c|}{ LOWER ELLENSBURG FORMATION } \\
\hline & \multirow{2}{*}{$\begin{array}{c}\mathrm{CCH} \\
94087\end{array}$} & \multicolumn{2}{|c|}{ PHA } & \multicolumn{2}{|c|}{ PHA } & \multicolumn{2}{|c|}{ PHA } & \multicolumn{2}{|c|}{ PHA } & \multirow[b]{2}{*}{ gerr } \\
\hline & & 8 error & 93107 & serr & 93108 & gerr & 93120 & 8err & 93121 & \\
\hline$\overline{\mathrm{Na}}$ & 1.55 & 0.40 & 2.43 & 0.26 & 2.56 & 0.25 & 1.57 & 0.35 & 2.64 & 0.32 \\
\hline $\mathrm{K} 8$ & 3.19 & 15.51 & 3.46 & 11.31 & 3.31 & 14.79 & 1.01 & $<0.01$ & 3.06 & 9.90 \\
\hline $\mathrm{Fe}$ & 3.05 & 0.98 & 2.44 & 1.00 & 1.49 & 1.19 & 4.67 & 0.79 & 1.66 & 1.75 \\
\hline Sc & 10.82 & 0.64 & 8.56 & 3.99 & 4.54 & 6.48 & 24.71 & 1.19 & 5.26 & 6.18 \\
\hline $\mathrm{Cr}$ & 7.40 & 27.03 & ----- & ---- & 3.42 & 30.35 & 6.06 & $<0.01$ & 2.91 & 44.88 \\
\hline Co & 23.65 & 1.73 & 4.25 & 6.22 & 2.12 & 6.11 & 9.66 & 3.77 & 2.51 & 8.72 \\
\hline $2 n$ & 84.17 & 24.41 & 54.84 & 35.56 & 39.49 & 30.12 & 110.32 & 32.42 & 33.29 & 44.28 \\
\hline $\mathrm{Ga}$ & ---- & ---- & ---- & ---- & 24.28 & 26.39 & 23.67 & 34.44 & 15.91 & $<0.01$ \\
\hline As & 7.08 & 16.84 & 5.43 & 26.71 & 10.44 & 12.56 & 31.95 & $<0.01$ & 13.30 & 12.72 \\
\hline $\mathrm{Br}$ & ---- & ----- & 0.21 & 27.18 & 0.21 & $<0.01$ & 0.22 & $<0.01$ & 0.36 & $<0.01$ \\
\hline $\mathrm{Rb}$ & 103.44 & 9.61 & 74.31 & 12.97 & 116.57 & 7.31 & 49.54 & $<0.01$ & 108.63 & 8.14 \\
\hline $\mathrm{sr}$ & 308.80 & 27.52 & ---- & -..- & 99.11 & 43.95 & 607.77 & 30.98 & 197.12 & 24.90 \\
\hline $\mathrm{Zr}$ & 250.76 & $<0.01$ & 125.03 & 34.35 & 124.91 & 28.87 & 211.12 & 35.57 & 127.49 & 28.56 \\
\hline $\mathrm{Sb}$ & $\cdots+$ & $-\ldots$ & 0.74 & 20.46 & 1.22 & $<0.01$ & 3.41 & 31.45 & 0.99 & 18.31 \\
\hline $\mathrm{Cs}$ & 6.21 & 8.41 & 2.91 & 6.94 & 5.23 & 3.16 & 2.14 & 13.74 & 5.18 & 3.35 \\
\hline $\mathrm{Ba}$ & 747.70 & 5.96 & 671.63 & 5.96 & 884.53 & 3.95 & 981.58 & 6.33 & 913.26 & 4.05 \\
\hline $\mathrm{La}$ & 36.03 & 2.14 & 24.93 & 3.40 & 33.03 & 2.67 & 25.38 & 2.71 & 31.47 & 3.57 \\
\hline $\mathrm{Ce}$ & 62.47 & 1.56 & 48.57 & 1.71 & 54.77 & 1.41 & 40.54 & 2.88 & 55.72 & 1.53 \\
\hline Nd & 34.14 & $<0.01$ & ---- & $\ldots$ & 22.82 & 36.46 & ----- & ---- & 21.39 & 31.16 \\
\hline $\mathrm{Sm}$ & 6.58 & 0.85 & 5.25 & 1.82 & 3.91 & 1.41 & 6.63 & 0.90 & 4.54 & 1.36 \\
\hline Eu & 1.25 & 2.99 & 1.00 & 4.95 & 0.78 & 4.05 & 1.93 & 2.48 & 0.80 & $<0.01$ \\
\hline $\mathrm{Tb}$ & 1.14 & $<0.01$ & 0.88 & 5.60 & 0.73 & 5.06 & 1.04 & $<0.01$ & 0.73 & $<0.01$ \\
\hline$Y b$ & 3.27 & 9.97 & 3.40 & 8.27 & 2.46 & 9.01 & 4.33 & 7.75 & 2.73 & 8.10 \\
\hline $\mathrm{Lu}$ & 0.58 & 11.31 & 0.50 & 6.30 & 0.31 & 24.94 & 0.62 & 7.31 & 0.39 & 13.40 \\
\hline $\mathrm{Hf}$ & 5.54 & 3.82 & 4.09 & 4.09 & 4.15 & 2.77 & 5.05 & 4.65 & 4.10 & 2.95 \\
\hline $\mathrm{Ta}$ & 1.04 & 14.27 & 1.10 & 15.19 & 0.76 & 11.27 & 3.13 & 27.98 & 0.82 & 10.79 \\
\hline $\mathrm{Th}$ & 13.27 & 1.30 & 7.71 & 1.96 & 12.65 & 1.14 & 4.71 & 4.10 & 12.30 & 1.24 \\
\hline $\mathrm{U}$ & 5.00 & 10.84 & 4.01 & $<0.01$ & 4.12 & 12.23 & 1.77 & 34.54 & 4.64 & 12.87 \\
\hline
\end{tabular}


APPENDIX C - GENERAL DESCRIPTION AND LOCATION OF ANALYZED SAMPLES

\begin{tabular}{|c|c|c|c|c|c|c|c|c|c|c|c|}
\hline \multicolumn{2}{|c|}{ Sampe \# } & \multirow{3}{*}{$\frac{X R F}{X}$} & \multirow{3}{*}{$\begin{array}{c}\text { INAA } \\
X\end{array}$} & \multirow[t]{2}{*}{ Description } & \multirow[t]{2}{*}{ Formation } & \multicolumn{6}{|c|}{ Location } \\
\hline & & & & & & Quad & T'ship & Range & Sect. & UTM-N & UTM-E \\
\hline$\overline{\mathrm{CCH}}$ & 94001 & & & tuff $>$ pyroclastic flow & upper Ell & Meeks Table & $16 \mathrm{~N}$ & $14 \mathrm{E}$ & 26 & 5189750 & 649650 \\
\hline $\mathrm{CCH}$ & 94003 & $\mathrm{x}$ & & andesite breccia & Eifes & Meeks Table & $16 \mathrm{~N}$ & $14 \mathrm{E}$ & 26 & 5190800 & 649050 \\
\hline $\mathrm{CCH}$ & 94004 & $\mathrm{x}$ & & andesite breccia & Fifes & Meeks Table & $16 \mathrm{~N}$ & $14 \mathrm{E}$ & 26 & 5190600 & 648800 \\
\hline $\mathrm{CCH}$ & 94005 & $\mathrm{x}$ & & andesite breccia & Fifes & Meeks Table & $16 \mathrm{~N}$ & $14 \mathrm{E}$ & 26 & 5190600 & 648800 \\
\hline $\mathrm{CCH}$ & 94006 & $\mathrm{x}$ & & tuff $>$ pumic fall & upper Ell & Meeks Table & $16 \mathrm{~N}$ & $15 \mathrm{E}$ & 19 & 5191600 & 651500 \\
\hline $\mathrm{CCH}$ & 94010 & $\mathrm{x}$ & & tuff $>$ pyroclastic flow & upper Ell & Meeks Table & $16 \mathrm{~N}$ & $14 \mathrm{E}$ & 24 & 5191400 & 650500 \\
\hline $\mathrm{CCH}$ & 94011 & $\mathrm{x}$ & & tuff > pyroclastic flow & lower Ell & Meeks Table & $17 \mathrm{~N}$ & $13 \mathrm{E}$ & 12 & 5204200 & 639500 \\
\hline $\mathrm{CCH}$ & 94013 & $\mathrm{x}$ & & tuff > pyroclastic flow & BRE & Meeks Table & $17 \mathrm{~N}$ & $13 \mathrm{E}$ & 22 & 5200500 & 637600 \\
\hline $\mathrm{CCH}$ & 94014 & $\mathrm{x}$ & & tuff $>$ pyroclastic flow & BRE & Meeks Table & $17 \mathrm{~N}$ & $13 \mathrm{E}$ & 22 & 5200050 & 636950 \\
\hline $\mathrm{CCH}$ & 94015 & $\mathrm{x}$ & & tuff $>$ pyroclastic flow & $\mathrm{BRF}$ & Meeks Table & $17 \mathrm{~N}$ & $13 \mathrm{E}$ & 22 & 5200300 & 636900 \\
\hline $\mathrm{CCH}$ & 94016 & $\mathrm{x}$ & & andesite & Andesite & Meeks Table & $17 \mathrm{~N}$ & $13 \mathrm{E}$ & 34 & 5197700 & 636400 \\
\hline $\mathrm{CCH}$ & 94017 & $\mathrm{x}$ & & dacite & dacite & Meeks Table & $17 \mathrm{~N}$ & $13 \mathrm{E}$ & 34 & 5196700 & 636900 \\
\hline $\mathrm{CCH}$ & 94018 & $\mathrm{x}$ & & andesite & Andesite & Meeks Table & $17 \mathrm{~N}$ & $13 \mathrm{E}$ & 34 & 5196400 & 636750 \\
\hline $\mathrm{CCH}$ & 94019 & $\mathrm{x}$ & $\mathrm{x}$ & dacite & OSM & Meeks Table & $16 \mathrm{~N}$ & $13 \mathrm{E}$ & 6 & 5195500 & 633300 \\
\hline $\mathrm{CCH}$ & 94020 & $x$ & $x$ & dacite & OSM & Meeks Table & $16 \mathrm{~N}$ & $13 \mathrm{E}$ & 17 & 5193600 & 634800 \\
\hline $\mathrm{CCH}$ & 94021 & $x$ & $x$ & tuff $>$ pumice zone in sediment & upper E11 & Meeks Table & $16 \mathrm{~N}$ & $13 \mathrm{E}$ & 27 & 5190450 & 647600 \\
\hline $\mathrm{CCH}$ & 94023 & $x$ & $x$ & tuff > pumice fall & upper Ell & Meeks Table & $16 \mathrm{~N}$ & $13 \mathrm{E}$ & 27 & 5190300 & 646950 \\
\hline $\mathrm{CCH}$ & 94024 & $x$ & $x$ & tuff $>$ reworked pumice & upper Ell & Meeks Table & $16 \mathrm{~N}$ & $13 \mathrm{E}$ & 27 & 5190300 & 646950 \\
\hline $\mathrm{CCH}$ & 94025 & $x$ & $x$ & tuff $>$ pyroclastic flow & upper Ell & Meeks Table & $16 \mathrm{~N}$ & $14 \mathrm{E}$ & 28 & 5190400 & 646500 \\
\hline $\mathrm{CCH}$ & 94026 & $\mathrm{x}$ & $x$ & pumice clast > conglomerate & upper Ell & Meeks Table & $16 \mathrm{~N}$ & $14 \mathrm{E}$ & 28 & 5190400 & 646500 \\
\hline $\mathrm{CCH}$ & 94027 & $x$ & $\mathrm{x}$ & tuff $>$ pyroclastic flow & upper Ell & Meeks Table & $16 \mathrm{~N}$ & $14 \mathrm{E}$ & 28 & 5190400 & 646500 \\
\hline $\mathrm{CCH}$ & 94028 & $x$ & $x$ & tuff $>$ pyroclastic flow & upper E11 & Meeks Table & $16 \mathrm{~N}$ & $14 \mathrm{E}$ & 28 & 5190400 & 646500 \\
\hline $\mathrm{CCH}$ & 94029 & $x$ & $\mathrm{x}$ & dacite clast > conglomerate & upper Ell & Meeks Table & $16 \mathrm{~N}$ & $14 \mathrm{E}$ & 28 & 5189000 & 646550 \\
\hline $\mathrm{CCH}$ & 94030 & $x$ & & tuff > pyroclastic flow & upper E11 & Meeks Table & $16 \mathrm{~N}$ & $14 \mathrm{E}$ & 28 & 5189000 & 646550 \\
\hline $\mathrm{CCH}$ & 94031 & $x$ & $\mathrm{x}$ & dacite clast > conglomerate & upper Ell & Meeks Table & $16 \mathrm{~N}$ & $14 \mathrm{E}$ & 28 & 5189900 & 646100 \\
\hline $\mathrm{CCH}$ & 94032 & $x$ & $\mathrm{x}$ & tuff > reworked pumice & upper Ell & Meeks Table & $16 \mathrm{~N}$ & $14 \mathrm{E}$ & 29 & 5189900 & 646100 \\
\hline $\mathrm{CCH}$ & 94033 & $\mathrm{x}$ & $x$ & dacite clast > lahar & upper Ell & Meeks Table & $16 \mathrm{~N}$ & $14 \mathrm{E}$ & 27 & 5190250 & 647100 \\
\hline $\mathrm{CCH}$ & 94035 & $x$ & $x$ & dacite clast > lahar & upper Ell & Meeks Table & $16 \mathrm{~N}$ & $14 \mathrm{E}$ & 28 & 5190100 & 646800 \\
\hline $\mathrm{CCH}$ & 94038 & $x$ & & tuff $>$ ash fall & upper Ell & Meeks Table & $16 \mathrm{~N}$ & $14 \mathrm{E}$ & 26 & 5189500 & 649500 \\
\hline $\mathrm{CCH}$ & 94039 & $x$ & $x$ & dacite clast > conglomerate & upper E11 & Meeks Table & $16 \mathrm{~N}$ & $14 \mathrm{E}$ & 26 & 5189400 & 648850 \\
\hline $\mathrm{CCH}$ & 94040 & $x$ & $x$ & tuff > pyroclastic flow & upper Ell & Meeks Table & $16 \mathrm{~N}$ & $14 \mathrm{E}$ & 26 & 5189300 & 649000 \\
\hline
\end{tabular}


APPENDIX C - GENERAL DESCRIPTION AND LOCATION OF ANALYZED SAMPLES CONTINUED

\begin{tabular}{|c|c|c|c|c|c|c|c|c|c|c|c|}
\hline \multirow{2}{*}{\multicolumn{2}{|c|}{ Sampe \# }} & \multirow{3}{*}{$\begin{array}{c}\mathrm{XRF} \\
\mathrm{X}\end{array}$} & \multirow{3}{*}{$\begin{array}{c}\text { INAA } \\
x\end{array}$} & \multirow[t]{2}{*}{ Description } & \multirow[t]{2}{*}{ Formation } & \multicolumn{6}{|c|}{ Location } \\
\hline & & & & & & Quad & T'ship & Range & Sect. & UTM-N & UTM-E \\
\hline$\overline{\mathrm{CCH}}$ & 94041 & & & dacite clast > lahar & upper Ell & Meeks Table & $16 \mathrm{~N}$ & $14 \mathrm{E}$ & 35 & 5189100 & 649350 \\
\hline $\mathrm{CCH}$ & 94042 & $\mathrm{x}$ & & tuff > reworked pumice & upper Ell & Cliffdell & $16 \mathrm{~N}$ & $14 \mathrm{E}$ & 13 & 5194000 & 650800 \\
\hline $\mathrm{CCH}$ & 94043 & $\mathrm{x}$ & & tuff $>$ ash fall & upper Ell & Cliffdell & $16 \mathrm{~N}$ & $14 \mathrm{E}$ & 13 & 5194000 & 650800 \\
\hline $\mathrm{CCH}$ & 94047 & $\mathrm{x}$ & & tuff > pyroclastic flow & Fifes & Cliffdell & $16 \mathrm{~N}$ & $14 \mathrm{E}$ & 11 & 5194800 & 648300 \\
\hline $\mathrm{CCH}$ & 94049 & $\mathrm{x}$ & & basalt & $\mathrm{CRB}$ & old Scab Mt. & $16 \mathrm{~N}$ & $13 \mathrm{E}$ & 2 & 5195850 & 639800 \\
\hline $\mathrm{CCH}$ & 94053 & $\mathrm{x}$ & & dacite & dacite & Timberwolf & $16 \mathrm{~N}$ & $13 \mathrm{E}$ & 22 & 5191450 & 637100 \\
\hline $\mathrm{CCH}$ & 94054 & $x$ & & andesite & Andesite & Timberwolf & $16 \mathrm{~N}$ & $13 \mathrm{E}$ & 21 & 5191050 & 637050 \\
\hline $\mathrm{CCH}$ & 94055 & $x$ & & andesite & Fifes & old Scab Mt. & $16 \mathrm{~N}$ & $13 \mathrm{E}$ & 22 & 5192000 & 637250 \\
\hline $\mathrm{CCH}$ & 94056 & $\mathrm{x}$ & & tuff $>$ pyroclastic flow & upper Ell & Cliffdell & $17 \mathrm{~N}$ & $13 E$ & 33 & 5197700 & 645000 \\
\hline $\mathrm{CCH}$ & 94058 & $\mathrm{x}$ & & tuff > lapilli fall & upper Ell & Cliffdell & $17 \mathrm{~N}$ & $14 \mathrm{E}$ & 33 & 5197600 & 645300 \\
\hline $\mathrm{CCH}$ & 94060 & $\mathrm{x}$ & $x$ & tuff $>$ pyroclastic flow & upper E11 & Cliffdell & $16 \mathrm{~N}$ & $14 \mathrm{E}$ & 23 & 5192100 & 648400 \\
\hline $\mathrm{CCH}$ & 94061 & $\mathrm{x}$ & $x$ & crystaline tuff > pyroclastic flow & lower Ell & Cliffdell & $16 \mathrm{~N}$ & $14 \mathrm{E}$ & 23 & 5192000 & 648600 \\
\hline $\mathrm{CCH}$ & 94062 & $\mathrm{x}$ & $\mathrm{x}$ & crystaline tuff $>$ pyroclastic flow & lower Ell & Cliffdell & $16 \mathrm{~N}$ & $14 \mathrm{E}$ & 23 & 5191800 & 648600 \\
\hline $\mathrm{CCH}$ & 94063 & $\mathrm{x}$ & $\mathrm{x}$ & tuff $>$ pyroclastic flow & lower Ell & Cliffdell & $16 \mathrm{~N}$ & $14 \mathrm{E}$ & 23 & 5191800 & 648600 \\
\hline $\mathrm{CCH}$ & 94064 & $\mathrm{x}$ & & matrix > lahar & lower Ell & Cliffdell & $16 \mathrm{~N}$ & $14 \mathrm{E}$ & 16 & 5193100 & 645600 \\
\hline $\mathrm{CCH}$ & 94065 & $\mathrm{x}$ & & tuff > ash fall & lower Ell & Cliffdell & $16 \mathrm{~N}$ & $14 \mathrm{E}$ & 16 & 5192900 & 645600 \\
\hline $\mathrm{CCH}$ & 94056 & $\mathrm{x}$ & & tuff $>$ ash fall & lower Ell & Cliffdell & $16 \mathrm{~N}$ & $14 \mathrm{E}$ & 17 & 5192900 & 645600 \\
\hline $\mathrm{CCH}$ & 94057 & $\mathrm{x}$ & & tuff > pyroclastic flow & lower Ell & Cliffdell & $16 \mathrm{~N}$ & $14 \mathrm{E}$ & 17 & 5193050 & 644800 \\
\hline $\mathrm{CCH}$ & 94068 & $\mathrm{x}$ & & basalt & $\mathrm{CRB}$ & old Scab Mt. & $17 \mathrm{~N}$ & $13 \mathrm{E}$ & 25 & 5199900 & 639200 \\
\hline $\mathrm{CCH}$ & 94069 & $\mathrm{x}$ & & basalt & CRB & old Scab Mt. & $17 \mathrm{~N}$ & $13 \mathrm{E}$ & 36 & 5197800 & 640200 \\
\hline $\mathrm{CCH}$ & 94070 & $\mathrm{x}$ & & tuff $>$ pyroclastic flow & lower Ell & Old Scab Mt. & $17 \mathrm{~N}$ & $14 \mathrm{E}$ & 20 & 5200700 & 642500 \\
\hline $\mathrm{CCH}$ & 94071 & $\mathrm{x}$ & & tuff > pyroclastic flow & lower Ell & Cliffdell & $17 \mathrm{~N}$ & $14 \mathrm{E}$ & 29 & 5199600 & 643250 \\
\hline $\mathrm{CCH}$ & 94072 & $\mathrm{x}$ & & basalt & CRB & Old Scab Mt. & $17 \mathrm{~N}$ & $14 \mathrm{E}$ & 31 & 5198200 & 641600 \\
\hline $\mathrm{CCH}$ & 94073 & $\mathrm{x}$ & & tuff $>$ pyroclastic flow & upper Ell & Cliffdell & $17 \mathrm{~N}$ & $14 \mathrm{E}$ & 34 & 5198200 & 645600 \\
\hline $\mathrm{CCH}$ & 94074 & $x$ & & tuff $>$ reworked ash & upper Ell & Cliffdell & $17 \mathrm{~N}$ & $14 \mathrm{E}$ & 34 & 5198200 & 645600 \\
\hline $\mathrm{CCH}$ & 94077 & $x$ & & crystaline tuff > pyroclastic flow & lower Ell & Old Scab Mt. & $17 \mathrm{~N}$ & $14 \mathrm{E}$ & 6 & 5205500 & 641100 \\
\hline $\mathrm{CCH}$ & 94078 & $\mathrm{x}$ & & tuff > lapilli fall & lower Ell & Cliffdell & $17 \mathrm{~N}$ & $14 \mathrm{E}$ & 10 & 5203400 & 646350 \\
\hline $\mathrm{CCH}$ & 94079 & $\mathrm{x}$ & $x$ & dacite & OSM & Old Scab Mt. & $16 \mathrm{~N}$ & $13 \mathrm{E}$ & 9 & 5195400 & 636400 \\
\hline $\mathrm{CCH}$ & 94080 & $x$ & & dacite & OSM & Old Scab Mt. & $16 \mathrm{~N}$ & $13 \mathrm{E}$ & 9 & 5194900 & 636300 \\
\hline $\mathrm{CCH}$ & 94081 & $x$ & $x$ & dacite & OSM & Old Scab Mt. & $16 \mathrm{~N}$ & $13 \mathrm{E}$ & 9 & 5194600 & 636250 \\
\hline $\mathrm{CCH}$ & 94082 & $x$ & & dacite & OSM & Old Scab Mt. & $16 \mathrm{~N}$ & $13 \mathrm{E}$ & 9 & 5194600 & 636050 \\
\hline
\end{tabular}


APPENDIX C - GENERAL DESCRIPTION AND LOCATION OF ANALYZED SAMPLES CONTINUED

\begin{tabular}{|c|c|c|c|c|c|c|c|c|c|c|c|}
\hline \multirow[t]{2}{*}{ Sams } & \multirow[t]{2}{*}{ se \# } & \multirow[t]{2}{*}{$\overline{\mathrm{XRF}}$} & \multirow[t]{2}{*}{ INAA } & \multirow[t]{2}{*}{ Description } & \multirow[t]{2}{*}{ Formation } & \multicolumn{6}{|c|}{ Location } \\
\hline & & & & & & Quad & T'ship & Range & Sect. & UTM-N & UTM-E \\
\hline $\mathrm{CCH}$ & 94083 & $\bar{x}$ & & dacite & OSM & Old Scab Mt. & $16 \mathrm{~N}$ & $13 \mathrm{E}$ & 9 & 5194800 & 636300 \\
\hline $\mathrm{CCH}$ & 94084 & $x$ & & crystaline tuff $>$ pyroclastic flow & upper Ell & Cliffdell & $16 \mathrm{~N}$ & $14 \mathrm{E}$ & 17 & 5193500 & 644300 \\
\hline $\mathrm{CCH}$ & 94085 & $\mathrm{x}$ & & dacite clast > conglomerate & upper Ell & Cliffdell & $16 \mathrm{~N}$ & $14 E$ & 17 & 5193500 & 644300 \\
\hline $\mathrm{CCH}$ & 94086 & $x$ & $\mathrm{x}$ & tuff $>$ pyroclastic flow & lower Ell & Cliffdell & $16 \mathrm{~N}$ & $14 \mathrm{E}$ & 17 & 5193700 & 643600 \\
\hline $\mathrm{CCH}$ & 94087 & $x$ & $\mathrm{x}$ & tuff $>$ pyroclastic flow & lower Ell & Cliffdell & $16 \mathrm{~N}$ & $14 \mathrm{E}$ & 17 & 5193500 & 643850 \\
\hline $\mathrm{CCH}$ & 94088 & $\mathrm{x}$ & & basait & CRB & Cliffdell & $16 \mathrm{~N}$ & $14 \mathrm{E}$ & 17 & 5193500 & 643850 \\
\hline $\mathrm{CCH}$ & 94091 & $\mathrm{x}$ & & tuff $>$ reworked tuff & upper Ell & Cliffdell & $16 \mathrm{~N}$ & $14 \mathrm{E}$ & 17 & 5193150 & 644200 \\
\hline $\mathrm{CCH}$ & 94092 & $\mathrm{x}$ & & tuff $>$ pyroclastic flow & upper Ell & Cliffdell & $16 \mathrm{~N}$ & $14 \mathrm{E}$ & 17 & 5193150 & 644200 \\
\hline $\mathrm{CCH}$ & 94093 & $\mathrm{x}$ & & dacite clast > conglomerate & upper Ell & Meeks Table & $16 \mathrm{~N}$ & $14 \mathrm{E}$ & 17 & 5192700 & 643950 \\
\hline $\mathrm{CCH}$ & 94094 & $\mathrm{x}$ & & tuff $>$ pyroclastic flow & upper Ell & Meeks Table & $16 \mathrm{~N}$ & $14 \mathrm{E}$ & 17 & 5192450 & 644200 \\
\hline $\mathrm{CCH}$ & 94095 & $\mathrm{x}$ & & tuff $>$ pyroclastic flow & upper Ell & Cliffdell & $16 \mathrm{~N}$ & $14 \mathrm{E}$ & 17 & 5192800 & 643500 \\
\hline $\mathrm{CCH}$ & 94096 & $x$ & $x$ & tuff $>$ pyroclastic flow & upper Ell & Timberwolf & $16 \mathrm{~N}$ & $14 E$ & 19 & 5191900 & 641900 \\
\hline $\mathrm{CCH}$ & 94097 & $\mathrm{x}$ & $x$ & lithic tuff > pyroclastic flow & upper Ell & Timberwolf & $16 \mathrm{~N}$ & $14 E$ & 19 & 5191900 & 642300 \\
\hline $\mathrm{CCH}$ & 94098 & $\mathrm{x}$ & & basalt & CRB & Timberwolf & $16 \mathrm{~N}$ & $14 \mathrm{E}$ & 19 & 5191750 & 642250 \\
\hline $\mathrm{CCH}$ & 94099 & $\mathrm{x}$ & & pumice clast > coglomerate & upper Ell & Timberwolf & $16 \mathrm{~N}$ & $14 \mathrm{E}$ & 18 & 5192250 & 643150 \\
\hline $\mathrm{CCH}$ & 94100 & $\mathrm{x}$ & & tuff $>$ pyroclastic flow & lower Ell & Cliffdell & $16 \mathrm{~N}$ & $14 \mathrm{E}$ & 17 & 5193100 & 644500 \\
\hline $\mathrm{CCH}$ & 94101 & $\mathrm{x}$ & & tuff $>$ pyroclastic flow & lower Ell & Meeks Table & $16 \mathrm{~N}$ & $14 \mathrm{E}$ & 17 & 5192300 & 644800 \\
\hline $\mathrm{CCH}$ & 94102 & $x$ & & dacite lava flow & Fifes & Meeks Table & $16 \mathrm{~N}$ & $14 \mathrm{E}$ & 21 & 5192100 & 645500 \\
\hline $\mathrm{CCH}$ & 94103 & $x$ & & tuff $>$ pyroclastic flow & upper Ell & Meeks Table & $16 \mathrm{~N}$ & $14 \mathrm{E}$ & 21 & 5191750 & 645300 \\
\hline $\mathrm{CCH}$ & 94104 & $x$ & & basalt & $\mathrm{CRB}$ & Meeks Table & $16 \mathrm{~N}$ & $14 \mathrm{E}$ & 21 & 5192100 & 645150 \\
\hline $\mathrm{CCH}$ & 94105 & $x$ & $\mathrm{x}$ & tuff $>$ pyroclastic flow & upper Ell & Cliffdell & $16 \mathrm{~N}$ & $14 \mathrm{E}$ & 8 & 5195050 & 644300 \\
\hline $\mathrm{CCH}$ & 94106 & $x$ & & pumice clast $>$ pyroclastic flow & upper Ell & Cliffdell & $16 \mathrm{~N}$ & $14 \mathrm{E}$ & 8 & 5195350 & 644550 \\
\hline $\mathrm{CCH}$ & 94107 & $\mathrm{x}$ & & tuff $>$ reworked ash & upper Ell & Cliffdell & $16 \mathrm{~N}$ & $14 \mathrm{E}$ & 4 & 5195550 & 645100 \\
\hline $\mathrm{CCH}$ & 94108 & $x$ & & dacite clast > lahar & upper Ell & Cliffdell & $16 \mathrm{~N}$ & $14 \mathrm{E}$ & 4 & 5195900 & 645050 \\
\hline $\mathrm{CCH}$ & 94109 & $x$ & & tuff $>$ pyroclastic flow & upper E11 & Cliffdell & $16 \mathrm{~N}$ & $14 \mathrm{E}$ & 4 & 5196400 & 645400 \\
\hline $\mathrm{CCH}$ & 94110 & $\mathrm{x}$ & & tuff $>$ pyroclastic flow & upper Ell & Cliffdell & $16 \mathrm{~N}$ & $14 \mathrm{E}$ & 4 & 5196550 & 645300 \\
\hline $\mathrm{CCH}$ & 94111 & $\mathrm{x}$ & $\mathrm{x}$ & dacite clast > lahar & upper Ell & Meeks Table & $16 \mathrm{~N}$ & $14 \mathrm{E}$ & 33 & 5188700 & 645700 \\
\hline $\mathrm{CCH}$ & 94112 & $\mathrm{x}$ & & basa $1 \mathrm{t}$ & $\mathrm{CRB}$ & Meeks Table & $16 \mathrm{~N}$ & $14 \mathrm{E}$ & 31 & 5188450 & 643300 \\
\hline $\mathrm{CCH}$ & 94113 & $\mathrm{x}$ & $x$ & tuff $>$ reworked & upper Ell & Meeks Table & $16 \mathrm{~N}$ & $14 \mathrm{E}$ & 32 & 5189850 & 645150 \\
\hline $\mathrm{CCH}$ & 94114 & $x$ & $x$ & dacite clast > lahar & upper Ell & Meeks Table & $16 \mathrm{~N}$ & $14 \mathrm{E}$ & 33 & 5189000 & 645450 \\
\hline $\mathrm{CCH}$ & 94115 & $x$ & $x$ & dacite clast > lahar & upper El1 & Meeks Table & $16 \mathrm{~N}$ & $14 E$ & 28 & 5189200 & 646100 \\
\hline
\end{tabular}


APPENDIX C - GENERAL DESCRIPTION AND LOCATION OF ANALYZED SAMPLES CONTINUED

\begin{tabular}{|c|c|c|c|c|c|c|c|c|c|c|c|}
\hline \multirow{2}{*}{\multicolumn{2}{|c|}{ Sampe \# }} & \multirow[t]{2}{*}{$\mathrm{XRF}$} & \multirow[t]{2}{*}{ INAA } & \multirow[t]{2}{*}{ Description } & \multirow[t]{2}{*}{ Formation } & \multicolumn{6}{|c|}{ Location } \\
\hline & & & & & & Quad & $T^{\prime} \operatorname{ship}$ & Range & Sect. & UTM-N & UTM-E \\
\hline$\overline{\mathrm{CCH}}$ & 94116 & $\bar{x}$ & & tuff > pyroclastic flow & upper E11 & Meeks Table & $16 \mathrm{~N}$ & $14 \mathrm{E}$ & 36 & 5188800 & 650550 \\
\hline $\mathrm{CCH}$ & 94117 & $x$ & & tuff > pyroclastic flow & upper Ell & Meeks Table & $16 \mathrm{~N}$ & $14 \mathrm{E}$ & 36 & 5188550 & 549950 \\
\hline $\mathrm{CCH}$ & 94118 & $x$ & & dacite clast > lahar & upper E11 & Meeks Table & $16 \mathrm{~N}$ & $14 \mathrm{E}$ & 35 & 5187600 & 648600 \\
\hline $\mathrm{CCH}$ & 94119 & $x$ & & tuff $>$ pyroclastic flow & upper E1l & Meeks Table & $15 \mathrm{~N}$ & $14 \mathrm{E}$ & 25 & 5189250 & 650850 \\
\hline $\mathrm{CCH}$ & 94120 & $x$ & & tuff > pyroclastic flow & upper Ell & Meeks Table & $16 \mathrm{~N}$ & $14 \mathrm{E}$ & 25 & 5389250 & 650850 \\
\hline $\mathrm{CCH}$ & 94122 & $\mathrm{x}$ & & dacite clast > conglomerate & upper E1l & Meeks Table & $16 \mathrm{~N}$ & $14 \mathrm{E}$ & 27 & 5190400 & 647700 \\
\hline $\mathrm{CCH}$ & 94123 & $x$ & & dacite clast > lahar & upper Ell & Meeks Table & $16 \mathrm{~N}$ & $14 \mathrm{E}$ & 28 & 5189500 & 645450 \\
\hline $\mathrm{CCH}$ & 94124 & $\mathrm{x}$ & $\mathrm{x}$ & dacitic lava & upper Ell & Meeks Table & $15 \mathrm{~N}$ & $14 \mathrm{E}$ & 1 & 5187100 & 641250 \\
\hline $\mathrm{CCH}$ & 94126 & $x$ & & dacite clast > pebbly sandstone & upper E11 & Meeks Table & $15 \mathrm{~N}$ & $14 \mathrm{E}$ & 1 & 5186400 & 650500 \\
\hline $\mathrm{CCH}$ & 94127 & $\mathrm{x}$ & $x$ & tuff $>$ pyroclastic flow & upper Ell & Meeks Table & $15 \mathrm{~N}$ & $14 \mathrm{E}$ & 1 & 5186400 & 650500 \\
\hline $\mathrm{CCH}$ & 94128 & $x$ & $x$ & tuff $>$ pyroclastic flow & upper Ell & Meeks Table & $15 \mathrm{~N}$ & $14 \mathrm{E}$ & 1 & 5186400 & 650500 \\
\hline $\mathrm{CCH}$ & 94129 & $x$ & & dacite clast > float & upper Ell & Meeks Table & $15 \mathrm{~N}$ & $14 \mathrm{E}$ & 1 & 5186400 & 650500 \\
\hline $\mathrm{CCH}$ & 94130 & $x$ & $x$ & tuff $>$ pyroclastic flow & upper Ell & Meeks Table & $15 \mathrm{~N}$ & $14 \mathrm{E}$ & 2 & 5186100 & 649600 \\
\hline PHA & 91105 & $\mathrm{x}$ & $x$ & dacite & dacite & & & & & & \\
\hline PHA & 93070 & $x$ & $x$ & dacite & dacite & & & & & & \\
\hline PHA & 93107 & $x$ & $x$ & & lower Ell & & & & & & \\
\hline PHA & 93108 & $x$ & $x$ & & lower Ell & & & & & & \\
\hline PHA & 93119 & $x$ & & & lower Ell & & & & & & \\
\hline PHA & 93120 & $x$ & $x$ & & lower Ell & & & & & & \\
\hline PHA & 93121 & $x$ & $\mathrm{x}$ & & lower Ell & & & & & & \\
\hline PHA & 94105 & $x$ & & & lower El] & Meeks Table & & & & & \\
\hline PHA & 94124 & $x$ & & dacite & dacite & & & & & & \\
\hline PHA & 94126 & $x$ & & dacite & dacite & & & & & & \\
\hline PHA & 94144 & $x$ & & dacite & dacite & & & & & & \\
\hline PHA & 94147 & $x$ & & dacite & dacite & & & & & & \\
\hline PHA & 94157 & $x$ & & dacite & dacite & & & & & & \\
\hline PHA & 94207 & $x$ & & dacite & dacite & & & & & & \\
\hline PHA & 94211 & $x$ & & dacite & dacite & & & & & & \\
\hline
\end{tabular}


APPENDIX D - Eigenvalues, Eigenvectors, and Calculated Factors

\begin{tabular}{|c|c|c|c|c|c|c|}
\hline & \multicolumn{3}{|c|}{ Eigenvalue } & & & \\
\hline & 1 & 2 & 3 & & & \\
\hline Value & 13.346 & $2.86 i$ & 0.382 & & & \\
\hline$\&$ Varience & 76.31 & 16.36 & 2.19 & & & \\
\hline \multirow[t]{2}{*}{ Cumulative 8} & 76.31 & 92.67 & 94.86 & & & \\
\hline & \multicolumn{3}{|c|}{ Eigenvectors } & \multicolumn{3}{|c|}{ Factor } \\
\hline Sample \# & 1 & 2 & 3 & 1 & 2 & 3 \\
\hline 94019 & -0.127 & 0.071 & 0.021 & $-4.64 E-01$ & $1.20 E-01$ & 1. $30 E-02$ \\
\hline 94020 & 0.318 & -0.044 & -0.004 & $1.16 E+00$ & $-7.44 \mathrm{E}-02$ & $-2.47 E-03$ \\
\hline 94079 & -0.038 & 0.06 & 0.004 & $-1.39 \mathrm{E}-01$ & $1.01 E-01$ & $2.47 \mathrm{E}-03$ \\
\hline 94080 & -0.079 & 0.071 & $5.70 E-04$ & $-2.89 \mathrm{E}-01$ & $1.20 \mathrm{E}-01$ & $3.52 E-04$ \\
\hline 94081 & -0.087 & 0.077 & 0.009 & $-3.18 \mathrm{E}-01$ & $1.30 \mathrm{E}-01$ & $5.56 E-03$ \\
\hline 94082 & -0.065 & 0.089 & 0.007 & $-2.37 E-01$ & $1.51 \mathrm{E}-01$ & $4.33 E-03$ \\
\hline 94083 & 0.04 & 0.038 & -0.009 & $1.46 E-01$ & $6.43 E-02$ & $-5.56 E-03$ \\
\hline 94001 & -0.205 & -0.039 & -0.003 & $-7.49 \mathrm{E}-01$ & $-6.60 \mathrm{E}-02$ & $-1.85 E-03$ \\
\hline 94006 & -0.12 & 0.039 & -0.003 & $-4.38 E-01$ & $6.60 \mathrm{E}-02$ & $-1.85 E-03$ \\
\hline 94010 & -0.268 & -0.028 & -0.015 & $-9.79 E-01$ & $-4.74 \mathrm{E}-02$ & $-9.27 E-03$ \\
\hline 94021 & -0.101 & 0.038 & 0.021 & $-3.69 E-01$ & $6.43 E-02$ & $1.30 E-02$ \\
\hline 94023 & 0.06 & 0.054 & -0.005 & $2.19 \mathrm{E}-01$ & $9.13 E-02$ & $-3.09 E-03$ \\
\hline 94024 & 0.224 & -0.035 & -0.019 & $8.18 \mathrm{E}-01$ & $-5.92 E-02$ & $-1.17 E-02$ \\
\hline 94025 & 0.034 & 0.043 & 0.046 & $1.24 \mathrm{E}-01$ & $7.27 E-02$ & $2.84 \mathrm{E}-02$ \\
\hline 94026 & -0.13 & -0.025 & -0.009 & $-4.75 E-01$ & $-4.23 E-02$ & $-5.56 \mathrm{E}-03$ \\
\hline 94027 & 0.07 & 0.103 & 0.052 & $2.56 \mathrm{E}-01$ & $1.74 \mathrm{E}-01$ & $3.21 \mathrm{E}-02$ \\
\hline 94028 & -0.188 & $2.20 E-04$ & 0.017 & $-6.87 E-01$ & $3.72 \mathrm{E}-04$ & $1.05 E-02$ \\
\hline 94029 & -0.223 & $7.50 \mathrm{E}-04$ & -0.01 & $-8.15 E-01$ & $1.27 E-03$ & $-6.18 \mathrm{E}-03$ \\
\hline 94030 & -0.106 & -0.016 & -0.009 & $-3.87 E-01$ & $-2.71 \mathrm{E}-02$ & $-5.56 \mathrm{E}-03$ \\
\hline 94031 & 0.001 & 0.025 & 0.017 & $3.65 \mathrm{E}-03$ & $4.23 E-02$ & $1.05 \mathrm{E}-02$ \\
\hline 94032 & -0.101 & 0.087 & 0.045 & $-3.69 E-01$ & $1.47 \mathrm{E}-01$ & $2.78 \mathrm{E}-02$ \\
\hline 94033 & -0.019 & 0.084 & 0.025 & $-6.94 E-02$ & $1.42 \mathrm{E}-01$ & $1.55 \mathrm{E}-02$ \\
\hline 94035 & -0.171 & -0.026 & -0.005 & $-6.25 E-01$ & $-4.40 \mathrm{E}-02$ & $-3.09 E-03$ \\
\hline 94038 & 0.223 & 0.121 & 0.052 & $8.15 \mathrm{E}-01$ & $2.05 E-01$ & $3.21 E-02$ \\
\hline 94039 & -0.232 & -0.035 & -0.016 & $-8.48 \mathrm{E}-01$ & $-5.92 \mathrm{E}-02$ & $-9.89 E-03$ \\
\hline 94040 & -0.307 & -0.035 & -0.011 & $-1.12 \mathrm{E}+00$ & $-5.92 E-02$ & $-6.80 E-03$ \\
\hline 94041 & 0.015 & -0.045 & -0.016 & $5.48 \mathrm{E}-02$ & $-7.61 \mathrm{E}-02$ & $-9.89 \mathrm{E}-03$ \\
\hline 94042 & 0.214 & -0.077 & 0.01 & $7.82 \mathrm{E}-01$ & $-1.30 E-01$ & $6.18 \mathrm{E}-03$ \\
\hline 94043 & -0.009 & 0.1 & 0.025 & $-3.29 E-02$ & $1.69 \mathrm{E}-01$ & $1.55 \mathrm{E}-02$ \\
\hline 94056 & 0.172 & 0.201 & 0.112 & $6.28 E-01$ & $3.40 \mathrm{E}-01$ & $6.92 \mathrm{E}-02$ \\
\hline 94058 & 0.031 & 0.021 & 0.049 & $1.13 \mathrm{E}-01$ & $3.55 E-02$ & $3.03 \mathrm{E}-02$ \\
\hline 94060 & -0.156 & 0.002 & -0.011 & $-5.70 E-01$ & $3.38 \mathrm{E}-03$ & $-6.80 \mathrm{E}-03$ \\
\hline 94073 & -0.198 & -0.043 & -0.016 & $-7.23 E-01$ & $-7.27 \mathrm{E}-02$ & $-9.89 \mathrm{E}-03$ \\
\hline 94074 & -0.012 & 0.04 & 0.004 & $-4.38 E-02$ & $6.77 \mathrm{E}-02$ & $2.47 \mathrm{E}-03$ \\
\hline 94078 & 0.201 & 0.055 & 0.202 & $7.34 \mathrm{E}-01$ & $9.30 \mathrm{E}-02$ & $1.25 \mathrm{E}-01$ \\
\hline 94084 & -0.078 & 0.041 & 0.014 & $-2.85 E-01$ & $6.93 \mathrm{E}-02$ & $8.65 \mathrm{E}-03$ \\
\hline 94085 & -0.237 & 0.006 & -0.034 & $-8.66 \mathrm{E}-01$ & $1.01 \mathrm{E}-02$ & $-2.10 E-02$ \\
\hline 94091 & -0.102 & 0.035 & 0.015 & $-3.73 E-01$ & $5.92 \mathrm{E}-02$ & $9.27 \mathrm{E}-03$ \\
\hline 94092 & -0.196 & 0.011 & -0.001 & $-7.16 \mathrm{E}-01$ & $1.86 \mathrm{E}-02$ & $-6.18 \mathrm{E}-04$ \\
\hline 94093 & -0.092 & 0.019 & 0.032 & $-3.36 E-01$ & $3.21 \mathrm{E}-02$ & $1.98 \mathrm{E}-02$ \\
\hline 94094 & 0.145 & 0.117 & 0.052 & 5. $30 \mathrm{E}-01$ & $1.98 \mathrm{E}-01$ & $3.21 \mathrm{E}-02$ \\
\hline 94095 & 0.056 & 0.075 & 0.019 & $2.05 \mathrm{E}-01$ & $1.27 \mathrm{E}-01$ & $1.17 \mathrm{E}-02$ \\
\hline 94096 & -0.146 & 0.016 & 0.027 & $-5.33 E-01$ & $2.71 \mathrm{E}-02$ & $1.67 \mathrm{E}-02$ \\
\hline 94097 & -0.189 & 0.003 & -0.02 & $-6.90 E-01$ & $5.07 \mathrm{E}-03$ & $-1.24 \mathrm{E}-02$ \\
\hline
\end{tabular}


APPENDIX D - Eigenvalues, Eigenvectors, and Calculated Factors

\begin{tabular}{|c|c|c|c|c|c|c|}
\hline \multirow[b]{2}{*}{ Sample \# } & \multicolumn{3}{|c|}{ Eigenvectors } & \multicolumn{3}{|c|}{ Eactor } \\
\hline & 1 & 2 & 3 & 1 & 2 & 3 \\
\hline 94099 & 0.06 & -0.009 & 0.001 & $2.19 E-01$ & $-1.52 \mathrm{E}-02$ & $6.18 \mathrm{E}-04$ \\
\hline 94103 & -0.196 & 0.027 & -0.019 & $-7.16 \mathrm{E}-01$ & $4.57 \mathrm{E}-02$ & $-1.17 E-02$ \\
\hline 94105 & -0.143 & 0.016 & -0.008 & $-5.22 E-01$ & $2.71 E-02$ & $-4.94 \mathrm{E}-03$ \\
\hline 94106 & -0.043 & -0.078 & -0.033 & $-1.57 \mathrm{E}-01$ & $-1.32 \mathrm{E}-01$ & $-2.04 E-02$ \\
\hline 94107 & 0.197 & 0.1 & 0.047 & $7.20 E-01$ & $1.69 \mathrm{E}-01$ & $2.90 \mathrm{E}-02$ \\
\hline 94108 & 0.192 & 0.134 & -0.065 & $7.01 \mathrm{E}-01$ & $2.27 E-01$ & $-4.02 E-02$ \\
\hline 94109 & -0.084 & -0.013 & 0.012 & $-3.07 E-01$ & $-2.20 E-02$ & $7.42 \mathrm{E}-03$ \\
\hline 94110 & 0.021 & 0.046 & -0.054 & $7.67 \mathrm{E}-02$ & $7.78 \mathrm{E}-02$ & $-3.34 \mathrm{E}-02$ \\
\hline 94111 & 0.242 & -0.06 & -0.027 & $8.84 E-0 i$ & $-1.01 E-01$ & $-1.67 E-02$ \\
\hline 94113 & 0.277 & -0.052 & 0.011 & $1.01 E+00$ & $-8.80 E-02$ & $6.80 E-03$ \\
\hline 94114 & 0.088 & 0.017 & 0.032 & $3.21 E-01$ & $2.88 E-02$ & 1. $98 \mathrm{E}-02$ \\
\hline 94115 & -0.205 & -0.059 & -0.034 & $-7.49 \mathrm{E}-01$ & $-9.98 E-02$ & $-2.10 \mathrm{E}-02$ \\
\hline 94116 & 0.123 & -0.108 & -0.026 & $4.49 E-01$ & $-1.83 E-01$ & $-1.61 \Sigma-02$ \\
\hline 94117 & 0.355 & -0.087 & -0.034 & 1. $30 E+00$ & $-1.47 \mathrm{E}-01$ & $-2.10 \mathrm{E}-02$ \\
\hline 94118 & 0.246 & -0.091 & -0.04 & $8.99 E-01$ & $-1.54 \mathrm{E}-01$ & $-2.47 E-02$ \\
\hline 94119 & 0.298 & -0.088 & -0.043 & $1.09 \mathrm{E}+00$ & $-1.49 \mathrm{E}-01$ & $-2.66 \mathrm{E}-02$ \\
\hline 94120 & 0.115 & -0.011 & -0.018 & $4.20 E-01$ & $-1.86 \mathrm{E}-02$ & $-1.11 \mathrm{E}-02$ \\
\hline 94122 & 0.093 & -0.001 & 0.009 & $3.40 E-01$ & $-1.69 \mathrm{E}-03$ & $5.56 \mathrm{E}-03$ \\
\hline 94123 & 0.202 & -0.038 & 0.005 & $7.38 \mathrm{E}-01$ & $-6.43 E-02$ & $3.09 \mathrm{E}-03$ \\
\hline 94124 & 0.354 & -0.102 & -0.037 & $1.29 \mathrm{E}+00$ & $-1.73 E-01$ & $-2.29 \mathrm{E}-02$ \\
\hline 94126 & -0.208 & 0.029 & 0.017 & $-7.60 \mathrm{E}-01$ & $4.91 E-02$ & $1.05 \mathrm{E}-02$ \\
\hline 94127 & 0.075 & -0.057 & -0.012 & $2.74 E-01$ & $-9.64 E-02$ & $-7.42 E-03$ \\
\hline 94128 & 0.445 & -0.011 & -0.051 & $1.63 E+00$ & $-1.86 \mathrm{E}-02$ & $-3.15 E-02$ \\
\hline 94129 & 0.268 & -0.11 & -0.04 & $9.79 \mathrm{E}-01$ & $-1.86 \mathrm{E}-01$ & $-2.47 \varepsilon-02$ \\
\hline 94130 & -0.47 & -0.105 & -0.028 & $-1.72 E+00$ & $-1.78 \mathrm{E}-01$ & $-1.73 E-02$ \\
\hline 94011 & 0.077 & -0.154 & 0.232 & $2.81 E-01$ & $-2.60 \mathrm{E}-01$ & $1.43 E-01$ \\
\hline 94061 & -0.162 & 0.038 & -0.077 & $-5.92 E-01$ & $6.43 \mathrm{E}-02$ & $-4.76 \mathrm{E}-02$ \\
\hline 94062 & -0.167 & 0.018 & -0.098 & $-6.10 E-01$ & $3.04 E-02$ & $-6.06 \mathrm{E}-02$ \\
\hline 94063 & -0.174 & 0.004 & -0.106 & $-6.36 E-01$ & $6.77 \mathrm{E}-03$ & $-6.55 E-02$ \\
\hline 94064 & -0.144 & -0.047 & 0.009 & $-5.26 \mathrm{E}-01$ & $-7.95 \mathrm{E}-02$ & $5.56 \mathrm{E}-03$ \\
\hline 94065 & 0.12 & -0.045 & 0.005 & $4.38 E-01$ & $-7.61 E-02$ & $3.09 \mathrm{E}-03$ \\
\hline 94066 & 0.063 & -0.033 & -0.002 & $2.30 \mathrm{E}-01$ & $-5.58 \mathrm{E}-02$ & $-1.24 E-03$ \\
\hline 94067 & -0.146 & -0.025 & 0.015 & $-5.33 E-01$ & $-4.23 \mathrm{E}-02$ & $9.27 \mathrm{E}-03$ \\
\hline 94070 & -0.129 & -0.047 & 0.073 & $-4.71 E-01$ & $-7.95 E-02$ & $4.51 E-02$ \\
\hline 94071 & 0.015 & -0.082 & 0.132 & $5.48 \mathrm{E}-02$ & $-1.39 \mathrm{E}-01$ & $8.16 E-02$ \\
\hline 94077 & 0.133 & 0.04 & -0.114 & $4.86 E-01$ & $6.77 \mathrm{E}-02$ & $-7.05 E-02$ \\
\hline 94086 & 0.154 & -0.001 & -0.088 & $5.63 E-01$ & $-1.69 \mathrm{E}-03$ & $-5.44 E-02$ \\
\hline 94087 & 0.12 & 0.013 & -0.053 & $4.38 E-01$ & $2.20 E-02$ & $-3.28 \mathrm{E}-02$ \\
\hline 94100 & -0.006 & -0.041 & 0.032 & $-2.19 \mathrm{E}-02$ & $-6.93 E-02$ & $1.98 \mathrm{E}-02$ \\
\hline 94101 & -0.083 & -0.02 & -0.024 & $-3.03 E-01$ & $-3.38 E-02$ & $-1.48 \mathrm{E}-02$ \\
\hline $\mathrm{H} 107$ & 0.094 & 0.002 & -0.069 & $3.43 \mathrm{E}-01$ & $3.38 E-03$ & $-4.26 E-02$ \\
\hline $\mathrm{H} 108$ & 0.158 & 0.037 & -0.14 & $5.77 E-01$ & $6.26 E-02$ & $-8.65 E-02$ \\
\hline H119 & -0.349 & -0.169 & 0.067 & $-1.27 E+00$ & $-2.86 E-01$ & $4.14 \mathrm{E}-02$ \\
\hline $\mathrm{H} 120$ & -0.024 & -0.023 & -0.025 & $-8.77 E-02$ & $-3.89 E-02$ & $-1.55 E-02$ \\
\hline H121 & 0.149 & 0.044 & -0.143 & $5.44 E-01$ & $7.44 E-02$ & $-8.84 E-02$ \\
\hline $\mathrm{H} 105$ & 0.18 & -0.092 & 0.153 & $6.58 E-01$ & $-1.56 \mathrm{E}-01$ & $9.46 \mathrm{E}-02$ \\
\hline
\end{tabular}

